\title{
Measuring the performance of geosimulation models by map comparison
}

Citation for published version (APA):

Hagen-Zanker, A. (2008). Measuring the performance of geosimulation models by map comparison.

[Doctoral Thesis, Maastricht University]. Universiteit Maastricht. https://doi.org/10.26481/dis.20081210ah

Document status and date:

Published: 01/01/2008

DOI:

10.26481/dis.20081210ah

Document Version:

Publisher's PDF, also known as Version of record

\section{Please check the document version of this publication:}

- A submitted manuscript is the version of the article upon submission and before peer-review. There can be important differences between the submitted version and the official published version of record.

People interested in the research are advised to contact the author for the final version of the publication, or visit the DOI to the publisher's website.

- The final author version and the galley proof are versions of the publication after peer review.

- The final published version features the final layout of the paper including the volume, issue and page numbers.

Link to publication

\footnotetext{
General rights rights.

- You may freely distribute the URL identifying the publication in the public portal. please follow below link for the End User Agreement:

www.umlib.nl/taverne-license

Take down policy

If you believe that this document breaches copyright please contact us at:

repository@maastrichtuniversity.nl

providing details and we will investigate your claim.
}

Copyright and moral rights for the publications made accessible in the public portal are retained by the authors and/or other copyright owners and it is a condition of accessing publications that users recognise and abide by the legal requirements associated with these

- Users may download and print one copy of any publication from the public portal for the purpose of private study or research.

- You may not further distribute the material or use it for any profit-making activity or commercial gain

If the publication is distributed under the terms of Article $25 \mathrm{fa}$ of the Dutch Copyright Act, indicated by the "Taverne" license above, 


\section{Measuring the performance of geosimulation models by map comparison}


ISBN: 978-90-9023734-3

Published by author, 1 November 2008:

Alex Hagen-Zanker

Maastrichter Grachtstraat 18-C

6211 BG Maastricht

The Netherlands

ahagen@riks.nl

Title: Measuring the performance of geosimulation models by map comparison

Title in Dutch: Het beoordelen van geosimulatiemodellen op basis van kaartvergelijking.

(C) Alex Hagen-Zanker. All rights reserved. No part of this publication may be reproduced, stored in a retrieval system, or transmitted, in any form or by any means, electronic, mechanical, photocopying, recording, or otherwise, without the prior permission in writing from the proprietor(s).

(C) Alex Hagen-Zanker. Alle rechten voorbehouden. Niets uit deze uitgave mag worden verveelvoudig, opgeslagen in een geautomatiseerd gegevensbestand, of openbaar gemaakt, in enige vorm of op enige wijze, hetzij elektronisch, mechanisch, door fotokopieën, opnamen, of op enige nadere manier, zonder voorafgaande schriftelijke toestemming van de rechthebbende(n).

Cover illustration: ( Saul Steinberg, View on the World from Ninth Avenue 
MEASURING THE PERFORMANCE OF

GEOSIMULATION MODELS BY MAP COMPARISON

\section{DISSERTATION}

to obtain the degree of Doctor at

the Maastricht University

on the authority of Rector Magnificus,

Prof. dr. G.P.M.F. Mols

in accordance with the decision of the Board of Deans,

to be defended in public

on Wednesday 10 December 2008 at 10:00 hours

by

Alex Hidde Hagen-Zanker 
Supervisors:

Prof. dr. P. Martens

Prof. dr. R. White (Memorial University of Newfoundland, Canada)

Assessment committee:

Prof. dr. J. Stel (chairman)

Prof. dr. ir. A. Bregt (Wageningen University)

Prof. dr. R. Leemans (Wageningen University)

Prof. dr. R. Peeters 


\section{Acknowledgements}

The work in this thesis has been published before in several journal papers, conference papers and technical reports. The table below gives an overview of the main sources for each chapter. I would like to express my gratitude to the co-authors, reviewer, editors, conference organizers and publishers for making these publications and this thesis possible.

\begin{tabular}{|c|c|}
\hline Ch. & Main sources \\
\hline \multirow[t]{2}{*}{1,8} & $\begin{array}{l}\text { Hagen-Zanker, A., van Loon, J., Maas, A., Straatman, B., de Nijs, T., \& Engelen, G. } \\
\text { (2005). Measuring performance of land use models: An evaluation framework for the } \\
\text { calibration and validation of integrated land use models featuring Cellular Automata. } \\
\text { Proceedings of the 14th European Colloquium on Theoretical and Quantitative } \\
\text { Geography, Universidade Nova de Lisboa, 1-11 (CD-ROM) }\end{array}$ \\
\hline & $\begin{array}{l}\text { Hagen-Zanker, A., \& Martens, P. (2008). Map comparison methods for comprehensive } \\
\text { assessment of geosimulation models. Proceedings of ICCSA 2008, Lecture Notes in } \\
\text { Computer Science 5072, Springer, 194-209 }\end{array}$ \\
\hline \multirow[t]{2}{*}{2} & $\begin{array}{l}\text { Hagen, A. (2002). Comparison of maps containing nominal data (Technical report). } \\
\text { Research Institute for Knowledge Systems. 1-101 }\end{array}$ \\
\hline & $\begin{array}{l}\text { Hagen, A. (2002). Multi-method assessment of map similarity. Proceedings of the } 5 \text { th } \\
\text { AGILE Conference on Geographic Information Science, Universitat de les Illes } \\
\text { Balares, 171-182 }\end{array}$ \\
\hline \multirow[t]{2}{*}{3} & $\begin{array}{l}\text { Hagen, A. (2002). Approaching human judgement in the automated comparison of } \\
\text { categorical maps. In Proceedings of the 4th International conference on Recent } \\
\text { Advances in Soft Computing, Nottingham Trent University, 1-6 (CD-ROM) }\end{array}$ \\
\hline & $\begin{array}{l}\text { Hagen, A. (2003). Fuzzy set approach to assessing similarity of categorical maps. } \\
\text { International Journal of Geographical Information Science, 17(3), 235-249. }\end{array}$ \\
\hline 4 & $\begin{array}{l}\text { Hagen-Zanker, A., Straatman, B., \& Uljee, I. (2005). Further developments of a fuzzy set } \\
\text { map comparison approach. International Journal of Geographical Information } \\
\text { Science, 19(7), 769-785. }\end{array}$ \\
\hline 5 & $\begin{array}{l}\text { Hagen-Zanker, A. (2006). Map comparison methods that simultaneously address overlap } \\
\text { and structure. Journal of Geographical Systems, 8(2), 165-185. }\end{array}$ \\
\hline 6 & $\begin{array}{l}\text { Hagen-Zanker, A., \& Lajoie, G. (2008). Neutral models of landscape change as } \\
\text { benchmarks in the assessment of model performance. Landscape and Urban } \\
\text { Planning, } 86(3-4), 284-296 \text {. }\end{array}$ \\
\hline \multirow[t]{2}{*}{7} & $\begin{array}{l}\text { Hagen-Zanker, A. (2007). Quantification and classification of urban change patterns. } \\
\text { Proceedings of the 9th International Conference on Geocomputation, National } \\
\text { University of Ireland, 1-3 (CD-ROM) }\end{array}$ \\
\hline & $\begin{array}{l}\text { Hagen-Zanker, A. (2007). A state-space representation for measuring urban change. } \\
\text { Proceedings of the 7th IALE World Congress (Vol. 2), International Association of } \\
\text { Landscape Ecology, 870-871. }\end{array}$ \\
\hline
\end{tabular}





\section{Preface}

I first become interested in the topic of map comparison during a conversation with Guy Engelen and Jean-Luc de Kok who were supervising my master's thesis at the time. Jean-Luc offhandedly remarked that the question how to compare maps is intriguing and unanswered. That thought lingered with me for a long time. As a Civil Engineering student I was used to knowledge being time-tested and set in stone. The idea that such rudimentary questions are still open and that it is possible to have an influence on how they are being answered was stimulating. It was this spirit of being at the frontier of new developments and pushing it forwards that attracted me to join RIKS and later to engage in the current research.

The first and foremost person to thank is Guy. With RIKS he built a company firmly based on his understanding of complex geographical systems proving the adage that nothing is more practical than a good theory. It gave me, whatever specific task I was working on, the confidence of working for a greater good. His trust and support from the beginning of my career at RIKS have been tremendous. Even at times when it was not self-evident: For example when we went to the Hague several times to present progress on a project where I had made little visible progress, when I (temporarily) started calling his previous work the "old way" of doing things, when my statistics suggested that a good alternative for our models is not modelling at all... Guy managed to keep confidence, be dedicated to producing quality work and have a long term vision.

When Hedwig van Delden and later also Rob Hermans took over the directorship of RIKS, external circumstances had changed. The company had grown and the types of contracts that were acquired demanded a more procedural way of working. Still, even in these harder times, Hedwig and Rob recognized the value of research and stimulated me to go through with this $\mathrm{PhD}$. Without their support it would not have been possible to finish this $\mathrm{PhD}$, thank you.

I want to thank my colleagues at RIKS for all their advice, patience, support and stimulating discussions, not to mention long debugging sessions: Bernhard Hahn, Jelle Hurkens, Joyce van Loon, Patrick Luja, Maarten van der Meulen, Arjan Maas, Saim Muhammad, Edith Schmeits, Yu-e Shi, Bas Straatman, Inge Uljee, Roel Vanhout, Jasper van Vliet and Rohan Wickramasuriya. I would like to thank Maarten, Inge and Bernhard especially for their continued interest and moral support for producing this thesis. 
I thank my supervisor Pim Martens for his patience, and whenever necessary, lack of patience, in the production of this thesis. The progress was irregular to say the least. Pim would often not hear from me for months and then be overloaded by a bulk of text in one go. Pim always found the time to evaluate the work, give pointed advice and keep track of the bigger picture.

My second supervisor Roger White has been a great help throughout the writing of this thesis As a regular visiting professor at the RIKS office he has always welcomed and shared new ideas. His open and encouraging approach to any idea or discussion is a great example to me. With his unique quality filter he ignores everything less clever or interesting and then refocuses the discussion to those ideas or remnants thereof that deserve further pondering.

All methods developed in this thesis are reflected in a software tool called the Map Comparison Kit. This tool was developed and extended by RIKS for the Netherlands Environmental Assessment Agency (PBL) in a number of projects coordinated by Hans Visser and Ton de Nijs. I have thoroughly enjoyed the cooperation. It is because of their recognition of the relevance of the work in this thesis and their critical involvement in the development of methods and software that the Map Comparison Kit stands as it is today. Aldrik Bakema and Karst Geurs were also closely involved at PBL, thank you for your critical but enthusiastic support. It is courtesy to PBL that the Map Comparison Kit is available for free on the Internet.

This last paragraph is reserved for Jessica. Science if often considered a life dedication and writing a thesis is compared to delivering a baby. I know this is not true. Your love, our life together and the joy of our daughter is much more important than anything else. Thank you for all your support and advice through all phases and in all aspects of writing this thesis. You bore with me when I was preoccupied, over-enthusiastic or pessimistic and celebrated with me when things worked out. Let's have many more celebrations! 


\section{Samenvatting}

Geosimulatie is een tak van geografie die ruimtelijke patronen en dynamiek probeert te doorgronden als het gevolg van de wisselwerking van kleine eenheden zoals huurders, landbezitters, weggebruikers, bomen, enzovoorts. Geosimulatiemodellen bepalen enkel hoe deze eenheden zich gedragen en de patronen op grote schaal zoals segregatie, verstedelijking, verkeersopstopping en bosbrand zullen spontaan ontstaan als het gevolg van de kleinschalige wisselwerkingen. Geosimulatie heeft een grote ontwikkeling doorgemaakt onder invloed van de mogelijkheden die steeds snellere computers bieden. Een eenvoudige bureaucomputer kan dienen als een virtueel laboratorium waarin onderzoekers hun eigen steden, verkeerssystemen, plattelandsgemeenschappen en natuurgebieden kunnen kweken.

Geosimulatiemodellen worden in toenemende mate gebruikt voor gebiedsspecifieke toepassingen. De onderzoekers creëren hun virtuele geografische systeem niet langer uit het niets, maar nemen een startsituatie op basis van werkelijke informatie. Van daaruit kunnen mogelijke toekomstige ontwikkelingen doorgerekend worden. Deze gebiedsspecifieke toepassingen zijn niet enkel wetenschappelijk van aard, maar ze worden ook gebruikt in beslissingsondersteunende systemen die inzicht bieden in te verwachten ontwikkelingen en de consequenties van verschillende opties.

De nieuwe generatie van geosimulatiemodelleurs ziet zich geconfronteerd met het probleem het realiteitsgehalte van de modellen te beoordelen. Richtlijnen voor 'goed modelleren' schrijven een aantal analytische stappen voor. Met name de stappen calibratie en validatie vereisen fitmaten die aangeven hoe goed de modelsituatie overeenkomt met de werkelijke situatie. Aangezien de uitvoer van de modellen overwegend kaarten zijn, ligt het voor de hand om ze te beoordelen op basis van kaartvergelijking. Het karakter van geosimulatiemodellen werpt echter een aantal obstakels op.

Eén probleem is dat de resolutie waarop het model is gedefinieerd niet overeenkomt met de schaal waarop de resultaten worden geinterpreteerd. De interesse in de modellen zit juist in de ruimtelijke structuren die opborrelen uit de wisselwerkingen tussen de kleine eenheden. Het idee van complexiteit speelt hierbij een belangrijke rol. Waneer het gedrag van elementen in het model wederzijds afhankelijk is ontstaan terugkoppelingsprocessen die kunnen leiden tot zelforganisatie, maar ook tot gevoeligheden voor kleine variaties en daarbij chaos en onvoorspelbaarheid. Het gevolg is dat zelfs een geosimulatiemodel dat 
de werkelijke processes perfect beschrijft niet in staat zal zijn om kaarten te produceren die tot in detail met de werkelijkheid overeenstemmen. Het is daarom niet afdoende om modellen te beoordelen op plek-tot-plek overeenstemming maar ook de patronen die ontstaan, moeten beoordeeld worden. Desalniettemin, bij gebiedsspecifieke toepassingen reikt het te ver om modellen enkel op globale patronen te beoordelen, ook de plaatsgebonden verdeling is van belang.

Aldus wordt een balans gezocht tussen het vinden van realistische patronen en het vinden van deze patronen op de juiste plek. Geosimulatiemodellen worden geacht ruimtelijke structuren te creëeren die realistisch zijn en ongeveer op de juiste plaatsen te vinden zijn. Bestaande vergelijkingsmethoden vinden een dergelijke balans niet. Zij zijn of lokaal, gebaseerd op plek-tot-plek overeenstemming, of het ander uiterste namelijk globaal, gebaseerd op maten die het hele landschap in een enkel getal samenvatten. Alhoewel formele methoden onttbreken, kan een expert een dergelijke vergelijking vrij eenvoudig maken door de kaarten te bekijken. Het is daarom niet vreemd dat in de dagelijkse praktijk geosimulatiemodellen vaak worden beoordeeld op basis van een dergelijke zichtvalidatie.

Zichtvalidatie is niet zonder problemen, het meest fundamementeel is het gebrek aan objectieve herhaalbaarheid. Een praktisch bezwaar is dat voor sommige taken, zoals calibratie, grote aantallen consistente beoordelingen nodig zijn. Een menselijke beoordelaar kost dan veel tijd en geld en zal waarschijnlijk te veel inconsistenties introduceren.

Dit proefschrift behelst een raamwerk voor het evalueren van modelprestaties. Het bestaat uit een aantal vergelijkingsmethoden die georganiseerd zijn aan de hand van twee assen. De eerste as maakt een onderscheid dat typisch wordt gemaakt in geografische informatiewetenschappen. De as is gebaseerd op het schaalniveau van de analyse-eenheden en loopt van lokaal, via focaal naar globaal. De tweede as is gebruikelijk in landschapsecologische toepassingen en onderscheidt of de vergelijking wordt gemaakt op basis van ruimtelijke structuur of de aanwezigheid van ruimtelijke elementen.

De Kappa statistiek wordt veel gebruikt om de overeenstemming in paarsgewijze categrische observaties uit te drukken. Het houdt geen rekening met ruimtelijke relaties, behalve plek-tot-plek (rastercel-tot-rastercel) overeenstemming, en is niet specifiek bedoeld voor het vergelijken van kaarten. De statistiek schaalt het percentage van overlap naar de verwachte overlap, gegeven het totale aantal observaties per categorie. Hierdoor vermengt de statistiek lokale (plek-tot-plek overeenstemming) en globale (de verwachte overstemming aspecten van de observaties). Dit proefschrift stelt een nieuwe uitsplitsing van de Kappa statistiek voor die Kappa uitdrukt als het product van twee componenten. De eerste component, Klocation, is een maat voor 
overeenstemming van de lokale aanwezigheid, en de tweede component, Khisto, is een maat voor de overeenstemming van de globale aanwezigheid.

In een verdere uitbreiding op de Kappa statistiek wordt nabijheid in rekenschap genomen. Onbestemdheid (fuzziness) van lokatie wordt in de analyse opgenomen zodat gelijke categorieën die op ongeveer dezelfde plek liggen een zekere mate van gelijkheid inhouden. Modellen die worden geëvalueerd op basis van de nieuwe Fuzzy Kappa worden aldus positief aangerekend wanneer ze categoriën op ongeveer de juiste locaties plaatsen. De Fuzzy Kappa is daarmee een maat van gelijkheid voor focale aanwezigheid.

Naast onbestemdheid van locatie houdt de Fuzzy Kappa statistiek ook rekening met de onbestemdheid van categoriën. Het vindt sommige combinaties van categoriën meer gelijkend dan andere. Dit aspect van de Fuzzy Kappa maakt het bijzonder geschikt voor het wegen van verschillende aspecten van ongelijkheid, bijvoorbeed fouten door omissie en commissie kunnen afzonderlijk gemeten en gewogen worden. Een positief neveneffect is dat de Fuzzy Kappa statistiek geschikt is om kaarten met ongelijke legenda's te vergelijken.

Landschapsmaten zijn veelgebruikt om structuur, in het bijzonder configuratie en samenstelling van kaarten, te beschrijven. De structuur is echter niet homogeen over de hele kaart en om ruimtelijke variabiliteit in rekenschap te nemen worden vergelijkingsmethoden voorgesteld op basis van een verschuivend kader. Deze methoden creëeren een extra kaartlaag waarin iedere rastercel op de kaart de waarde krijgt van de landschapsmaat die hoort bij het kader dat gecentreerd is op die cel. Deze landschapsmaat-kaartlagen worden vervolgens vergeleken op basis van een cel-per-cel vergelijking. Door deze aanpak wordt het geëvalueerde model beoordeeld op de mate waarin (ongeveer) de juiste structuren worden gevonden op (ongeveer) de juiste locaties. De kaartvergelijking is dus van het type focale structuur.

De eerste verkenning van een methode voor het vergelijken van veranderingspatronen in plaats van statische eindkaarten wordt gepresenteerd. Dit is een veelbelovende aanpak aangezien het geosimulatiemodellen aanspreekt op hun dynamische karakter. De methode is gebaseerd op een toestandsruimte benadering die veranderingen in verscheidene aspecten van ruimtelijke structuur registreert en vergelijkt. Het is nog niet duidelijk in hoeverre de discretizering van de toestandsruimte naar afgebakende klasses de resultaten een structurele afwijking geeft. Verder onderzoek naar dit type vergelijking is aanbevolen, niet in het minst omdat het een vergelijking is van globale structuur. Het globale karaketer houdt in dat de dynamiek van verschillende gebieden onderling vergeleken kan worden, hetgeen de basis kan zijn voor een klassificatie van stedelijke veranderingspatronen.

Een tweede obstakel bij het beoordelen van geosimulatiemodellen op basis van kaartvergelijking komt voort uit het dynamische karakter van de modellen en de relatief geringe veranderingen die over een simulatieperiode kunnen optreden. 
Hierdoor kan het voorkomen dat een hoge mate van overeenstemming tussen modelresultaat en werkelijkheid niet zozeer een gevolg is van de kwaliteit van het model, maar simpelweg een aanwijzing is dat er weinig veranderd is over de simulatieperiode. Het risico op een verkeerder interpratie en te groot vertrouwen in geosimulatiemodellen is hierdoor aannemelijk.

Een overoptimistische interpretatie van modelresultaten kan worden voorkomen door modellen te evalueren relatief ten opziche van referentiemodellen. Deze referentiemodellen zijn onderhevig aan dezelfde randvoorwaarden en beperkingen als het geëvalueerde model en bevatten verder geen specifieke processen behalve een weerstand tegen verandering. Daardoor zijn het neutrale modellen van landschapsverandering. Het verschil in prestatie tussen de neutrale modellen en het geëvalueerde geosimulatiemodel kan worden toegeschreven aan de processen die wel in het geosimulatiemodel aanwezig zijn, maar niet in de neutrale modellen. Een bijkomend voordeel van het gebruik van referentiemodellen is dat gelijkheidsmaten over verschillende grootheden en in verschillende eenheden onderling vergelijkbaar worden. Het is daardoor mogelijk om sterke en zwakke punten van het model te herkennen.

Alle nieuw geïntroduceerde methoden zijn toegepast op een aantal casussen, met een nadruk op de validatie van landgebruiksmodellen op basis van Cellulaire Automaten. Uit de casussen blijkt dat de beoordelingen door de nieuwe methoden goed aansluiten op zichtvalidatie, maar ook in staat zijn om patronen van verschillen te herkennen die voor de menselijke beoordelaar moeilijk te herkennen zijn. Het gebruik van referentiemodellen blijkt onmisbaar te zijn. Er is een sterke correlatie tussen de historische verandering en de modelfit en alleen met referentiemodellen is het mogelijk de kritische grenswaarden vast te stellen.

De mogelijke toepassingen van de vergelijkingsmethoden reiken verder dan de validatie van landgebruiksmodellen. Verwante problemen spelen ook in de ecologie, hydrologie en meteorologie. Behalve voor validatie kunnen de methoden ingezet worden om historische veranderingen te karakteriseren en om kaartclassificaties te beoordelen, bijvoorbeeld classificaties op basis van satelietbeelden en luchtopnamen. Uit een korte verkenning van de respons in de wetenschappelijke literatuur blijkt dat deze toepassingen inderdaad plaatsvinden.

Een tot nu toe niet verwezenlijkte mogelijkheid is de integratie van de kaartvergelijkingsmethoden in verdere ruimtelijke analyse. In principe kan iedere analyse met een vergelijking van categorische kaarten baat hebben bij de geografische nuance van de nieuwe methoden. Gezien de uitgangspunten van het onderzoek ligt integratie in calibratieprocedures het meest voor de hand. De methoden kunnen dan worden gebruikt als fitmaat maar ook als steun bij het vinden van de juiste parameteraanpassing. De verscheidene belichtingshoeken 
van kaartvergelijking kunnen bijzonder geschikt zijn voor een calibratie op basis van optimisatieroutines met meervoudige doelfuncties.

De classificatie op basis satelietbeelden biedt ook veel ruimte voor integratie van vergelijkingsmethoden. De methoden kunnen bijdragen aan het onderscheiden van werkelijke veranderingen en classificatiefouten en, vooral de focale structuur vergelijkingen, kunnen nuttig zijn voor classificatiemethoden die de context van een pixel in rekenschap nemen. 



\section{Summary}

Geosimulation is a filed in geography that seeks to understand geographical patterns and dynamics as the consequence of the interactions between individual entities, like tenants, land owners, car drivers, trees, etc. Geosimulation models prescribe the behaviour of these entities and as a product of the interactions between the entities large scale patterns, such as segregation, urban sprawl, road congestion, forest fire, etc. emerge. The field of geosimulation is spurred by advances in computing. As a consequence, the average desk computer can function as a virtual laboratory, where researchers can breed their own virtual cities, transport systems, rural societies, forests, etc.

Geosimulation models are increasingly finding region specific applications. Rather than using the models to let geographical structures arise from scratch, the models are fed with a real initial situation. The model is then used to elaborate possible future developments. Such region specific applications are not only used for scientific purposes. They have become part of decision support systems that help decision makers foresee future development and assess the consequences of alternative decisions.

The problem that confronts the new generation of geosimulation modellers is to assess how well their virtual worlds correspond to reality. 'Good modelling practice' prescribes different analytical steps in the modelling process. Of these, calibration and validation require the modeller to express the goodness-of-fit of the model. Since the results of the models typically are maps, it makes perfect sense to address this question by map comparison; however the nature of geosimulation models provides some particular challenges that need to be considered first.

One problem is that the resolution at which the model is defined is generally not equal to the scale at which the results are interpreted. The interest in the models lies in the geographical structures that unroll as a consequence of the interactions of the individual entities, rather than the entities themselves. The concept of complexity is relevant here. Typically the elements in the model are mutually dependent on each others behaviour. This causes feedback processes and self-organization, but also making the models sensitive to small deviations to the extent that they are chaotic or unpredictable. The consequence is that even a geosimulation model that perfectly captures the dynamics of a geographical system cannot be expected to produce maps that correspond perfectly to reality. The models should therefore not be evaluated just at the 
location-to-location level, but in terms of the patterns that emerge. On the other hand, when applying a model for a particular region, one is not just interested in the global patterns, but also how the patterns are distributed in space.

A balance has to be sought between finding realistic patterns and finding them at the right location. The geosimulation model should create spatial configurations that are similar to reality and place them in approximately the right locations. Existing comparison methods do not strike such a balance. They are either local and based on cell-by-cell overlap, or global and based on metrics summarizing the whole landscape in a single value. Despite the lack of formal methods, an expert can make this kind of balanced comparison by just looking at the map. It is therefore not surprising that in practice geosimulation models are often evaluated on the basis of such subjective face validation.

There are several problems associated with face validation, most pressingly the lack of objective reproducibility. A practical concern of face validation is that for some tasks, such as calibration, large numbers of consistent assessments are required. Depending on a human judge of map similarity may be too timeconsuming, costly and prone to inconsistencies.

This thesis introduces a framework to evaluate model performance. It applies a number of metrics that can be categorized according to two axes. The first axis is typical of geographical information science and is based on the spatial unit of the analysis; it ranges from local, via focal to global. The second axis is more commonly applied in landscape ecological applications and discerns whether structural aspects of landscape are considered or just the presence of landscape elements.

The Kappa statistic is a frequently used statistic expressing the agreement of pair-wise categorical observations. It does not consider spatial relations except for cell-by-cell overlap and is not specifically aimed at comparing maps; nevertheless it is often used as a map comparison method. The Kappa statistic scales the percentage of agreement between observations to the agreement that could be expected by chance given the number of observations of each class. As such, the statistic confounds local (agreement) and global (expected agreement) aspects of the observation. A new breakdown of the Kappa statistic is proposed that makes it the product of two components: The Klocation statistic that expresses the agreement in local presence and the Khisto statistic that expresses the agreement in global presence (quantity).

In a further elaboration of the Kappa statistic, proximity is taken into account. Fuzziness of location is incorporated in the analysis such that categories found at approximately the right location are considered similar as well. It thus evaluates agreement in focal presence.

Besides fuzziness of location the Fuzzy Kappa statistic also accounts for fuzziness of categories, considering some pairs of categories more similar than 
others. This aspect of the comparison method is useful to weight particular aspects of similarity, for instance to separate the errors due to omission and commission. As a side-effect, the Fuzzy Kappa statistic can well be used to compare maps with different legends.

Map patterns are commonly described using landscape metrics that summarize different aspects of configuration and composition. Landscape structure is not homogenous over the map however and to acknowledge this variability, a comparison method on the basis of moving windows is introduced. In this method extra map layers are created that attribute the landscape metric pertaining to the window surrounding the cell to every cell on the map. These metric layers are then compared on a cell-by-cell basis. Effectively, the evaluated model is assessed on the degree to which that the right types of spatial structures are found at the right locations. The comparison is one of focal structure.

First results of a method comparing patterns of change instead of the static endstates of a simulation run are presented. This is a promising approach since it brings the analysis of model performance closer to the dynamic nature of geosimulation models which is their essential characteristic. The approach is based on a state-space representation in which the transitions of different aspects of spatial structure are registered and compared. It is not yet clear ,however, how the method is affected by the discretization of state-space into classes, which possibly introduces some bias. Further research into this type of comparison is recommended, not in the least since it is a global structure comparison. This means that the dynamics of different regions can be compared against each other and the method can thus be the foundation of a classification of landscape change patterns.

Another problem of validating geosimulation models originates from the dynamic nature of the simulation models and the relatively small number of changes that may occur over a simulation period. A high agreement between model and reality is then not necessarily the consequence of the agreement between the processes in model and reality, but can be just an indication that not much has changed. This causes a risk of misinterpretation and false confidence in geosimulation models.

Misinterpretation of model results can be avoided if geosimulation model are evaluated relative to reference models instead. Such models should be subject to the same constraints and boundary conditions as the investigated model but represent no specific processes except for intertia, therefore they are neutral model of landscape change. The difference in performance between the neutral models and the evaluated geosimulation model can then be attributed to the model relations that are present in the geosimulation model but not in the neutral model. A further advantage of expressing model performance relative to that of a reference model is that metrics measured at various scales become 
mutually comparable. Thus it becomes possible to identify strengths and weaknesses of the evaluated model.

All new methods proposed here have been tested on a number of cases, with an emphasis on the validation of Cellular Automata based land use models. In these cases it is found that the newly developed methods produce assessments that are consistent with face validation, but also have the capacity to highlight patterns of change that the human analyst may not recognize. The use of reference models proved indispensable. It appears that there is a strong correlation between the amount of historical change and geosimulation models capacity to reproduce this change. Only by using reference models it is possible to find the critical thresholds of model performance.

The potential for application is much wider than the validation of Cellular Automata land use models. There are very similar problems in the fields of ecology, meteorology and hydrology. Besides evaluating simulation models, the methods can be used to characterize historical change or to validate spatial classifications, for instance on the basis of remote sensing. A brief review of the response in the scientific literature shows that all these kinds of applications are indeed being made.

A potential that is still unfulfilled is to integrate these new map comparison method in other spatial analysis. In principle any type of analysis that includes the calculation of fit between two categorical maps has the potential to benefit from the geographically nuanced methods introduced in this thesis. Closest to the original objectives, the methods can be integrated in calibration procedures, not only by calculating a goodness-of-fit of model and reality but also by suggesting parameter values to adjust. The multi-faceted assessment of map similarity may be particularly suited for calibration procedure on the basis of multi-objective optimization.

The classification of remote sensing imagery also offers various possibilities. The methods can contribute to making the distinction between real changes in the landscape and errors in the classification. Furthermore, the focal structure comparisons can be of use in contextual classification methods that take the spatial configuration into account when classifying pixels. 


\section{Contents}

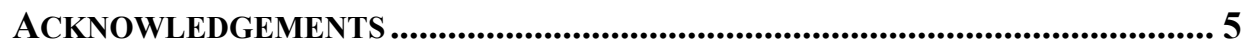

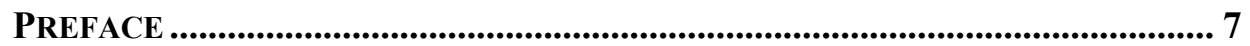

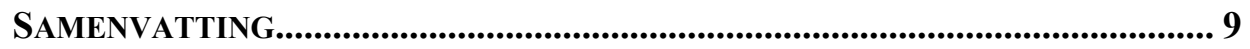

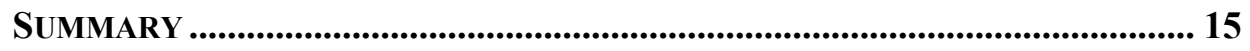

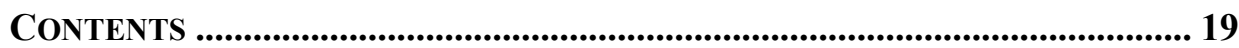

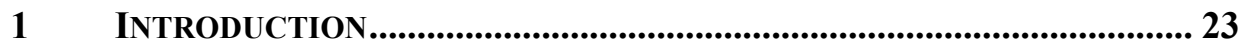

1.1 Background 23

1.1.1 A history of raster based spatial dynamic modelling 24

1.1.2 Good modelling practice: Validation and calibration 27

1.1.3 Constrained Cellular Automata land use model 29

1.1.4 Earlier work on evaluating spatial models by map comparison 31

1.2 Study objectives 33

1.2.1 The challenge of validating geosimulation models 33

1.2.2 Research questions 36

1.3 Methodological approach 36

1.3.1 Local, focal and global operators 36

$\begin{array}{ll}\text { 1.3.2 } & \text { Presence and structure indicators } \\ \text { 1.3.37 }\end{array}$

1.3.3 Thesis outline 38

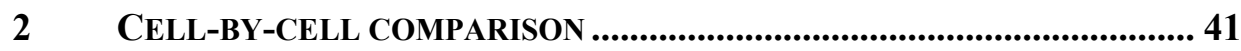

2.1 Introduction 41

2.2 Method 44

2.2.1 Kappa statistic $\quad 44$

2.2.2 Klocation 46

$\begin{array}{lll}2.2 .3 & \text { Kquantity } & 47\end{array}$

$\begin{array}{lll}2.2 .4 & \text { Khisto } & 49\end{array}$

2.2.5 Kappa statistics per category $\quad 49$

2.2.6 Reference level 50

2.3 Results $\quad 51$

2.3.1 Case A: EUROMOVE 51

2.3.2 Case B: Environment Explorer 53

$\begin{array}{lll}2.4 \text { Conclusion } & 57\end{array}$ 


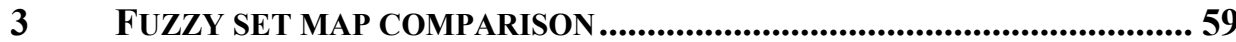

$\begin{array}{lll}3.1 & \text { Introduction } & 59\end{array}$

3.2 Method 60

3.2.2 Representation of fuzziness of categories 61

3.2.3 Representation of fuzziness of location 62

3.2.4 The comparison 64

3.2.5 Two-way comparison $\quad 65$

3.2.6 Fuzzy Kappa statistic for overall map similarity 66

3.3 Derivation of the Fuzzy Kappa statistic 68

3.3.1 Calculation of the overall similarity 69

3.3.2 Calculation of the expected overall similarity 72

3.3.3 Calculation of the Fuzzy Kappa 73

3.4 Results $\quad 74$

3.4.1 Case A: Synthetic dataset $\quad 74$

3.4.2 Case B: The Dublin model 76

3.4.3 Case C: Approaching human judgement 79

3.5 Conclusion $\quad 82$

4 ADVANCED USE OF CATEGORICAL FUZZINESS ....................................85

4.1 Introduction $\quad 85$

4.2 Method $\quad 85$

4.2.2 Setting legend items equal 86

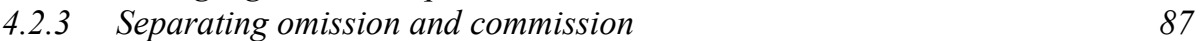

4.2.4 Unequal legends 88

$\begin{array}{lll}4.3 & \text { Results } & 90\end{array}$

4.3.1 Case A: Synthetic dataset 90

4.3.2 Case B: The Dublin model 93

4.3.3 Case C: The Netherlands with unequal legends 97

$\begin{array}{ll}4.4 \text { Conclusion } & 101\end{array}$

5 BALANCING PRESENCE AND STRUCTURE............................................. 103

5.1 Introduction 103

5.2 Method 105

5.2.1 Defining neighbourhoods and local abundance 105

5.2.2 Neighbourhood overlap and similarity of composition 107

5.2.3 Neighbourhood overlap summarized in contingency tables 108

5.2.4 Neighbourhood similarity of configuration 110

$\begin{array}{lll}5.3 \text { Data } & 112\end{array}$

5.3.1 Virtual Workshop 112

5.3.2 Preprocessing of data set D1 112

$\begin{array}{lll}5.4 \text { Results } & 115\end{array}$

5.4.1 Comparison results of data set D1 (Reclassified) 115 
5.4.2 Comparison results of data set D2 119

$\begin{array}{lll}5.5 & \text { Discussion } & 123\end{array}$

$\begin{array}{lll}5.6 & \text { Conclusion } & 124\end{array}$

6 UNITING COMPARISONS OVER MULTIPLE CRITERIA ...................... 125

$\begin{array}{lll}6.1 & \text { Introduction } & 125\end{array}$

6.2 Method 126

6.2.1 General procedure 126

6.2.2 Neutral models of landscape change 128

6.2.3 Performance criteria 130

6.2.4 Normalization 134

6.3 The case of La Réunion: study area, data and model 135

$\begin{array}{lll}6.3 .1 & \text { Study area } & 135\end{array}$

6.3.2 Data 137

6.4 Results 138

6.4.1 Model performance at multiple scales and criteria 138

6.4.2 Sensitivity 141

$\begin{array}{lll}6.5 & \text { Discussion } & 145\end{array}$

$\begin{array}{lll}6.6 & \text { Conclusion } & 147\end{array}$

7 PROSPECTS FOR COMPARING PATTERNS OF CHANGE ...................... 149

$\begin{array}{lll}7.1 & \text { Introduction } & 149\end{array}$

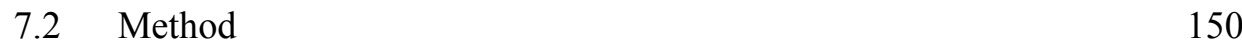

$\begin{array}{lll}7.3 & \text { Results } & 152\end{array}$

$\begin{array}{lll}7.4 & \text { Conclusion } & 156\end{array}$

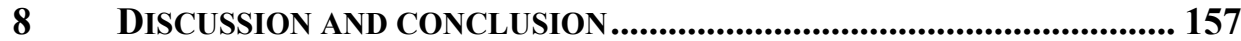

8.1 Comprehensive assessment of model performance 157

8.2 New perspectives for model development 159

8.3 Validation of metrics, the importance of visualization 161

8.4 Implementation in Map Comparison Kit 162

8.5 Current applications and further developments 163

REFERENCES .............................................................................................. 167

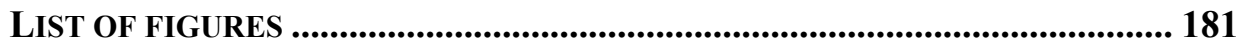

LIST OF TABLES ............................................................................... 185

BIOGRAPHY ............................................................................................. 187 



\section{Introduction}

\subsection{Background}

In recent years the field of high resolution simulation of geographical systems has flourished. Simulation models that are actor oriented and explicit in space and time have found applications in theoretical experiments as well as planning practice, where they help spatial planners foresee future developments and understand the consequences of different decisions and scenarios. The development of these models is ongoing. Whereas early developments were spurred by the boost in computing power (e.g. Tobler 1970), current developments are helped by software advances that bring the development of complex simulation models within the reach of many potential users (Karssenberg et al. 2001, Railsback et al. 2006).

This field is increasingly recognized under the term geosimulation (Benenson \& Torrens 2004). Geosimulation models make use of the possibilities of modern computing and seek to grasp the essence of complex geographical systems, for example cities at the level of individual entities (e.g. tenants, land owners, car drivers). Large scale patterns that are seen in reality (e.g. urban sprawl, segregation, congestion) are not hard-coded into the model, but instead emerge from interaction between the entities. Geosimulation is therefore a form of microsimulation with an emphasis on geographical entities and processes.

New scientific and technological developments pose new problems and require new tools and techniques. One problem that confronts the new generation of geosimulation modellers is how to validate the models and more generally how to measure model performance. This requires data, of course, but more importantly it requires concepts and methods to define and quantify correspondence between model and reality.

Since the main output of these models are geographical maps, this thesis approaches model performance evaluation by means of map comparison. For a model to be valid, the result map should be similar to the maps that depict reality. As maps can be interpreted from many perspectives, there are also many aspects of map similarity. This thesis will introduce a number of methods to quantify aspects of map similarity. Furthermore, it will introduce analytical techniques to assess these different interpretations in a consistent manner, in order to identify strengths and weaknesses of the model at hand. 


\section{Chapter 1}

This introduction will present a background of the problem by presenting highlights from the short history of raster based spatial dynamic modelling. This review illustrates how the field has expanded from the initial strictly mathematical constructs, via abstract models with strong analogies to real world phenomena to the current comprehensive planning-oriented region-specific geosimulation models.

The development towards comprehensive representation and region-specific implementations calls for a more application-oriented and functional approach to model calibration and validation. Therefore the different analytical steps generally recognized as good modelling practice will be discussed. Some philosophical and theoretical issues are discussed in this context: there has been considerable scientific debate about the meaning of validation and the Popperian question if validation is possible at all?

Given the context of spatial modelling and good modelling practice, section 1.3 presents the research objectives and the specific problems that need to be addressed. The chapters of this thesis fit well within a spatial analytical framework. Section 1.4 presents this framework and clarifies how the various chapters fit within.

\subsubsection{A history of raster based spatial dynamic modelling}

The history of raster based spatial modelling is a short one and a starting point was the development of Cellular Automata models by Von Neumann and Ulam at the Los Alamos National Laboratory in the 1940's. The two researchers had very diverse interests, crystal growth and the mechanics of self-reproduction, but used the same mathematical construction of Cellular Automata (Codd 1968).

Cellular Automata (CA) are mathematical constructions with the following characteristics:

- discrete space: Cellular Automata represent space on the basis of a regular lattice. In this thesis the lattice invariably is a two-dimensional rectangular grid, but there are also applications on hexagonal grids, in one dimension or more than two dimensions. The elements in the lattice are called cells.

- discrete states: The cells in the lattice belong to one of a limited number of states. In land use models, these states are land use or land cover categories.

- discrete time: Cellular Automata are dynamic, the state of cells changes over time. More specifically, all cells are updated simultaneously in regular time steps.

- transition rule: The transition rule provides the formalism for cells to change state. The input to the transition rule is the state of the cell and the states found in its neighbourhood. 
- neighbourhood: The neighbourhood of a cell consists of those cells in a fixed spatial relation to it. For instance, the neighbourhood can consist of the 4 or 8 adjacent cells.

Cellular Automata models offer a platform to investigate the relationship between micro-level behaviour (at the scale of the grid cell and the neighbourhood) and macro-level patterns at the scale of the whole lattice. It is precisely this relationship that raised the interest of mathematicians. Conway's Game of Life (Gardner 1970) is perhaps the most effective demonstration that simple rules can cause complex patterns. In this Cellular Automata model, cells in a regular square grid can be in one of two states, alive or dead. Dead cells become alive if exactly three of their eight neighbours are alive. Alive cells remain alive only if two or three of their neighbours are alive. On the basis of these rules simple initial patterns evolve rapidly to landscapes with static, oscillating and moving structures.

Wolfram (1986) used Cellular Automata to investigate dynamic systems more rigorously and identified four classes of dynamics

- Type I: The system evolves to a homogenic situation

- Type II: The system evolves to simple separate structures

- Type III: The system results in chaotic structures

- Type IV: The system results in complex patterns of local structures

The models by Von Neumann, Ulam, Conway and Wolfram are first and foremost mathematical constructions and their relation with real world phenomena is only at the highest level of abstraction. Notwithstanding, at this level it is a strong analogy that even gives rise to the radical idea that the real world is a Cellular Automaton (Zuse 1969).

Bak et al. (1988) used CA models of virtual sandpiles to demonstrate the mechanics of self-organised criticality. Bak et al. (1988) were not particularly interested in sandpiles, but point to a widespread phenomenon in physics. Nevertheless the computational model has a clear physical counterpart, allowing the authors to invite their readers to go to the beach and re-enact the experiments.

The spatial nature of raster based models makes them of particular interest for geographical applications and in particular the neighbour based transition rule of CA models offers potential for representing geographical processes. The discrete nature of space, time and state is computationally advantageous but not crucial. It is therefore not uncommon to find raster based geographical models that are CA-like but in fact do not have all the characteristics defining a CA.

An early example of such a geographical model is the dynamical model of segregation by Schelling (1971). With his model Schelling investigated the dynamics that underlie the formation of ghettos. The model represents plots on a regular grid. These plots have one of three possible states; white tenant, black 


\section{Chapter 1}

tenant or unoccupied. The model then assumes a degree of happiness that depends on the number of same-coloured neighbours. If that number is below a threshold value, the tenant moves randomly to an unoccupied plot. This model is not strictly speaking a CA model, since tenants do not move simultaneously but one at a time. Simulations with the model present a surprising conclusion on the relation between micro-behaviour and macro-patterns: even if tenants only have mild segregationist tendency (i.e. they do not like to be a small minority), their combined actions may lead to strongly segregated patterns.

The Schelling model addresses the real issue of segregation. Nevertheless, it is still a highly abstract model which is not specific to a particular region. A further development is the model of Tobler (1970). This model is a spatially explicit simulation model that represents urban growth in the Detroit region. This region specific model also shares some characteristics with $\mathrm{CA}$; it is grid based and the dynamics are governed by neighbourhood interaction. It is a model of population density however, and the number of possible states is practically infinite. In a later paper (Tobler 1979) the link between Cellular Automata and geographical simulation models is explicitly made.

The land use model that is of particular interest in this thesis is the Constrained Cellular Automata (CCA) model of White et al. (1997). Implementations of this model are evaluated as part of the cases in most chapters. This choice of model is not surprising since the organization that initiated and supported this research, Research Institute for Knowledge Systems, is the same that maintains, develops and commercializes the CCA model in the form of Planning Support Systems. The model is exemplary, however, if not a fore-runner of recent developments in land use modelling.

The first application of the model concerned an imaginary island with characteristics typical of Caribbean islands (Engelen et al. 1995). Later applications focused on the city of the Cincinnati Metropolitan Area on a timescale of more than 100 years (White et al. 1997). Further developments have elaborated the use of GIS data, including road network data and the dynamic integration with socio-economic land use models at multiple scales (White \& Engelen 2000). The model became part of Policy Support Systems, such as the Environment Explorer (Engelen et al. 2003, de Nijs et al. 2004). Currently the model is the cornerstone of several modelling frameworks of urban and regional growth, meaning that new regional applications can be set up within hours, including the METRONAMICA (van Delden \& Engelen 2006) and MOLAND (Barredo \& Demicheli 2003, White et al. 2000) frameworks.

This development towards continuously higher levels of operability also led to increasing demand in analytical tools and procedures concerning model set up and calibration (Geertman et al. 2007, Straatman et al. 2004, Verburg et al. 2004, White \& Engelen 2003). Other land use models have followed similar trajectories. In particular the SLEUTH Cellular Automata model (Clarke et al. 
1997) has been steadily developed and been subject to methodological refinements and empirical and theoretical analysis (Dietzel \& Clarke 2004, Dietzel et al. 2005, Herold et al. 2005, Jantz \& Goetz 2005, Silva \& Clarke 2002)

Cellular Automata modelling of land use processes is a field that remains under development. New developments take place in different directions, for instance integrating processes at multiple scales (Andersson et al. 2002, White 2006) incorporating economic principles in the CA rules (Webster \& Wu 1999a,b) and modelling land use-transport interaction (Geurs et al. 2006).

\subsubsection{Good modelling practice: Validation and calibration}

The previous section sketches the development from theoretical models towards highly operable models applied for region specific explorations and predictions. This development brings a perspective to spatial modelling that is more like engineering than theoretical science. Therefore it is worthwhile to consider the modelling practice in the field of hydrology. In this field the engineering approach has a much longer history and even though there appears to be considerable discussion about semantics and definitions, there is also consensus on the actual procedures. Refsgaard \& Henriksen (2004) discuss the literature and propose a set of definitions that is workable and pays tribute to the different points of view.

The discussion on semantics is best summarized by the contributions of Oreskes et al. (1994) and Rykiel (1996). Oreskes et al. (1994) makes strong philosophical reservations, along the lines of Popper (1959), to the use of the terms 'verification', 'validation' and 'confirmation': As geographical (earth science) models represent open systems they cannot be proven to represent an absolute truth. The word verification is misleading unless it is limited to a closed system. For instance it can be verified that a computer implementation represents a mathematical set of equations with a pre-determined precision. The word validation does not carry the meaning of absolute truth, but still of an 'establishment of legitimacy'. It can refer to actual model code, but due to its generic scope should not refer to model results for a particular situation. The word confirmation is actually the strongest qualification that particular model results can attain. In other words, model results do not prove anything, we can consider ourselves lucky if they do not falsify the theory behind our models.

Rykiel (1996) takes a stance that is not based on philosophical notions but on the paragmatic needs that arise when using models. He argues that regardless of linguistic matters, models need to be evaluated concerning their fitness for the intended use. One may apply any term to describe this process, but the commonly used 'validation' is quite appropriate.

In this thesis the line of thought of Rykiel (1996) is followed. The considerations of Oreskes et al. (1994) seem to relate more to the realm of basic 


\section{Chapter 1}

physics, the modelling of processes on the basis of first principles. For the models evaluated in this thesis, this is not the case. These models are highly simplified representations of reality. Everybody knows that landscapes are not regular grids composed of homogenous squares, that 4 to 20 categories are not sufficient to describe the full variability in land use patterns, that actors (people, companies, spatial planners) are not all identical and do not form grid-cell sized consortia to develop activities at new locations at yearly intervals. Therefore, the word validation can hardly give a false impression of universal truth.

Refsgaard \& Henriksen (2004) make a useful distinction between the conceptual model, the model (computer) code and the site-specific model (i.e. the specification of the model for a particular location or region). This thesis is concerned primarily with the site-specific model. The analytical tasks that the methods in this thesis are intended to support are model calibration and model validation for which performance criteria are required. These are defined by Refsgaard \& Henriksen (2004) as follows:

"Model calibration: The procedure of adjustment of parameter values of a model to reproduce the response of reality within the range of accuracy specified in the performance criteria."

"Model validation: Substantiation that a model within its domain of applicability possesses a satisfactory range of accuracy consistent with the intended application of the model."

"Performance criteria: Level of acceptable agreement between model and reality. The performance criteria apply both for calibration and validation."

One may argue about details of these definitions, for instance calibration is often seen as a process of optimization, rather than aiming for a 'range of accuracy'. Likewise, the definition of a 'level of acceptable agreement' for performance criteria is not always possible or necessary. These are details however and more importantly it should be noted that Refsgaard \& Henriksen (2004) stipulate the need of assessing the agreement between model and reality, but do not provide guidelines on how this should be measured. Such measurement of model agreement is precisely the subject of this thesis and to place this work in the framework of Refsgaard \& Henriksen the following definition needs to be added.

Goodness-of-fit metric: Metric that expresses the agreement between model and reality.

Goodness-of-fit metrics used in calibration and validation are not necessarily the same, since the objectives of calibration and validation are different The objective of calibration is optimization and therefore typically requires a single metric of goodness-of-fit, the exception being calibrations based on multipleobjective optimization (Gupta et al. 1998). Even when calibration requires only a single optimization criterion, the process of selecting parameters to change 
and their adjusted value can be helped a variety of metrics. The purpose of validation is to provide insight; therefore a multi-dimensional assessment of performance is most appropriate.

Ideally calibration and validation take place over independent datasets, because the site and/or time-period of the intended application generally differ from those of the calibration dataset. This is not by definition, and performance of the calibration dataset may be used as an indication of model validity. It must be stressed however that in such cases spatial and temporal stationarity are not investigated and the risk of over-calibration is evident. Over-calibration means that model parameters are tuned towards the eccentricities of the calibration period and not the general time-invariant processes.

\subsubsection{Constrained Cellular Automata land use model}

The CCA is a spatially explicit, dynamic land use model. The main variable of the model is a raster land use map. The state of every cell represents its land use class (e.g. residential, industrial, forest, agriculture). Over the course of a simulation the land use map is iteratively updated, typically in time steps of one year.

The land use map is updated with each iteration to satisfy the exogenous land area demands. In other words, the model does not determine the total area of different land use classes, but only their spatial distribution as the model is constrained by the total area demands.

The land use transitions are driven by the endogenous variable of land use potential, which is calculated for every location (cell) and each land use class. Land use potential is a function of several factors, in particular neighbourhood effect, physical suitability, accessibility and zoning, according to the following equation:

$$
P_{k, a}=f\left(r_{k, a} N_{k, a} S_{k, a} A_{k, a} Z_{k, a}\right)
$$

Equation 1.1

where:

$P_{k, a} \quad$ potential for land use class $k$ at location $a$

$r_{k, a} \quad$ Random perturbation factor for land use class $k$ at location $a$

$N_{k, a} \quad$ neighbourhood effect for land use class $k$ at location $a$

$S_{k, a} \quad$ Physical suitability for land use class $k$ at location $a$

$A_{k, a} \quad$ Accessibility of land use class $k$ at location $a$

$Z_{k, a} \quad$ Zoning status for land use class $k$ at location $a$

$f(\ldots)$ Total potential function

The precise form of the total potential function differs between applications, but generally it is a product of the different factors listed above. 


\section{Chapter 1}

Of the factors, suitability, accessibility and zoning are static data layers; they are either constant over the course of a simulation or modelled by means of exogenous scenarios. Physical suitability reflects aspects of soil, topography and climate that impact the aptness of a location for sustaining different land use classes. Accessibility reflects the degree to which every location is serviced by the infrastructure network and is modelled on the basis of the distance to links and nodes in the network. Zoning maps reflect the zoning status of locations for particular land uses (allowed, not-allowed) at different moments in time.

The neighbourhood effect, expressed in equation 1.2 below, is the dynamic component of the land use potential. It expresses how the presence of land use classes in the surrounding of a location affectvthe aptness of that location to sustain different land use classes.

$$
\mathrm{N}_{\mathrm{k}, \mathrm{a}}=\sum_{\mathrm{b}} \mathrm{w}_{\mathrm{d}(\mathrm{a}, \mathrm{b}), \mathrm{k}, \mathrm{L}(\mathrm{b})}
$$

Equation 1.2

where:

$\mathrm{N}_{\mathrm{k}, \mathrm{a}} \quad$ Neighbourhood effect of cell $a$ for land use class $k$.

$\mathrm{w}_{\mathrm{d}, \mathrm{k}, \mathrm{l}} \quad$ Impact of land use class $l$ on the neighbourhood effect for land use $k$ at distance $d$.

$b \quad$ Index that iterates over all cells in the neighbourhood of cell $a$. The neighbourhood consists of all cells within a given distance of $a$.

$d(a, b)$ Distance between cell $a$ and $b$. Since the model operates on a regular raster, the number of within a given radius possible distances is limited.

$L$ (b) Land use class found at cell $b$

Note that the neighbourhood of a location includes the location itself; therefore the neighbourhood effect includes the effect of land use inertia and conversion costs.

The neighbourhood effect in the potential function qualifies the model as a Cellular Automata model and underlies the self-organizing behaviour of the model. The complexity of the model arises from the fact that the spatial distribution of land use classes is governed by the potential layers, which in turn depend on the land uses pattern.

The interaction between total area demands and land use potential takes place through the allocation mechanism. This mechanism iteratively finds the (still unassigned) cell with the highest value over the potential maps of all land use classes (of which area demands are yet unmet), and assigns the cell to the corresponding land use class. 
The CCA model provides a particular challenge for performance measurement. The issue is that the resolution at which the model is defined is not equal to the scale at which the results are interpreted. The purpose of the model is not to perfectly predict the land use class at individual locations, instead it aims to capture the processes that underly the formation urban morphology..

The straightforward cell-by-cell assessment of agreement would not do justice to the objectives of the model. Instead, it is necessary to develop metrics that express the similarity spatial structure. It is evident that this is not likely to be captured in a single objective metric as there are many ways of considering spatial structure. This inherent subjectivity may be a motivation for some to suffice with a face validation (e.g. Batty 2005).

Another challenge is posed by the dynamical nature of the model and the relatively small number of changes that occurs over a simulation period. It is not uncommon for land use models to attain agreement percentages of $95 \%$ between reality and model (Pontius et al. 2008). This is, however, invariably due to the fact that land use patterns at the beginning of the simulation period are highly similar to those at the end. Rules of thumb in the field of remote sensing consider $85 \%$ agreement already an acceptable fit (Foody 2008). There is a real risk of misinterpretation and false confidence in land use models.

\subsubsection{Earlier work on evaluating spatial models by map comparison}

Relatively little work has been done on the evaluation of spatial models in particular by means of map comparison. Nevertheless, the literature offers a few key papers that will be discussed here because they provide the starting point for the research at hand. Three basic approaches to map comparison are put forward in the literature.

The first approach is cell-by-cell comparison. In this approach the cells in the two maps are treated as independent paired observations. This means that all spatial relations except for direct overlap are ignored, but has the advantage that the large body of non-spatial statistics becomes usable. In particular in the medical sciences, studies on the basis of paired observations are common, for instance the comparison of diagnosed and actual disease. A key contribution in this field is the Kappa statistic by Cohen (1960). This statistic 'corrects' the fraction of agreement between observation for the level of agreement expected from a random pairing of the observations. With this correction a bias is resolved that would reward overestimating common observations and underestimating rare observations.

The Kappa statistic has been taken up as a map comparison method by Monserud \& Leemans (1992) who apply it to the comparison of vegetation maps resulting from spatial models. The authors extend the use of the Kappa 


\section{Chapter 1}

statistic by not only applying it as an overall agreement measure, but also to assess the agreement pertaining to individual categories on the map.

Another influential paper applying the Kappa statistic to map comparison is Pontius (2000). He introduces several variations of the Kappa statistic, in particular to separately register the effect of errors in quantity and errors in location. This is particularly useful when considering the so-called double penalty effect which holds that the presence of a cell of a category is predicted correctly but at the wrong place is registered as two errors: once where the category is predicted but should not be and once where it is not predicted but should be. On the other, hand if the presence of that same category was not predicted at all, only one error would be registered: where it is not predicted, but should be.

The second approach to map comparison seeks to introduce spatial structure by evaluating the maps on the basis of step-wise aggregations. This method is proposed by Costanza (1989). The premise of this method is that with every step the cells in the map are aggregated to cells with double the cell length (i.e. $2 * 2,4 * 4,8 * 8, \ldots)$. With each aggregation errors in opposite direction (i.e. overestimations and underestimations) cancel each other out and fewer errors remain at that particular level of aggregation. Thus the method offers a multiscale approach to map comparison.

The third approach to map comparison is based on the comparison of global landscape metrics (Turner et al. 1989). In this approach the maps being compared are first summarized by metrics expressing aspects of spatial structure such as the size and orientation of clusters or patches after which the values of the metrics are compared. In this approach the notion of spatial correspondence is completely lost; it is in principle possible to compare maps that do not even overlap. This 'a-spatial' approach to spatial analysis is common in landscape ecology and in this context the FRAGSTATS software (McGarical et al. 2002) is noteworthy. This free software is used to calculate a wide range of landscape metrics.

Landscape metrics are in first instance developed for their relevance in ecological applications. Urban geography, however, also has its specialized metrics: In particular fractal analysis has been recognized to capture the typical scale-invariance of urban morphology (Batty \& Longley 1994). Fractal measures have been used to assess the performance of CA models (White et al. 1997). 


\subsection{Study objectives}

\subsubsection{The challenge of validating geosimulation models}

The development of map comparison methods in this thesis has a particular focus; it is aimed at the evaluation of geosimulation models and more specifically the calibration and validation of Cellular Automata land use models. In the end there should be a good level of understanding as well as methods and tools to support these tasks.

The relevance of such methods goes well beyond that specific purpose. Spatial simulation models are found in many disciplines and the circumstances that necessitate a simulation approach are the same that require the model results to be evaluated in terms of structure and patterns. The simulation approach to modelling is not the most desireable solution. Preferably a model is resolved analytically and the integration over time and space is captured in a single equation that can be readily applied. An advantage of such 'solved' models is that numerical errors associated with discretization of time and space are avoided. Furthermore, an analytical solution offers many possibilities for uncertainty analysis, sensitivity analysis, optimization, etc.

Given these advantages of analytical solutions, it is obvious to only resort to simulation approaches when analytical solutions are not available. Two main complications may cause this need. Firstly, it may be the case that the complexity of the model makes it impossible to find an analytical solution: Interactions in a model cause systems of actions and reactions and the nonlinear relation between these leave the model without an analytical solution. Complex does not necessarily mean complicated; it may well be that a very simple model gives rise to non-linear dynamics that cannot be solved analytically. A well-known mathematical problem is posed by the NavierStokes equations that describe fluid dynamics. These are a simple set of equations capturing fluid motion by the conversation of mass and energy. Nevertheless, any application of this model besides the most trivial requires a numerical approximation (Chorin 1968).

A second reason for resorting to simulation approaches is the appearance of non-homogenous and non-continuous boundary conditions. It may be that a model has an analytical solution under standardized circumstances but this analytical solution becomes infeasible under real conditions. For spatial models a typical boundary condition is the initial spatial configuration (i.e. landscape), such a configuration is rarely homogenous, as there are spatial variations in many factors: Elevation, climate, soil, land cover, etc. Even linear models, lacking any feedback processes are best applied through simulation because of spatial and temporal heterogeneity (e.g. Verburg et al. 2002).

The complex nature of some models puts considerable strain on the possibility of assessing their correspondence to reality. Small perturbations in the input, for 


\section{Chapter 1}

instance stochastic variation or measurement errors can develop into considerable differences in the final results. Such models should not be evaluated on the basis of one-to-one agreement with real spatial configurations. In fact, a one-to-one fit with reality would undermine the idea of complexity and self-organization and suggest a mis-specification of the model. Instead, the models should be assessed at a higher level of abstraction in terms of the patterns, frequencies and distributions that they create.

Likewise, models that recognize spatial heterogeneity should also be evaluated in terms of their heterogeneity; it does not only matter what the model predicts but also for which location it makes those predictions. A one-to-one agreement between model and reality is a reasonable objective for that kind of model.

An interesting situation arises when both conditions apply simultaneously; a simulation approach is followed both because of complexity and spatial heterogeneity. This causes a friction in the objective of model evaluation that is the root of methodological development in this thesis:

1. Simulation models that represent spatial interaction should be evaluated in terms of the spatial structures that unfold from these interactions

2. Simulation models that are applied for specific regions should be evaluated in terms of their representation of these regions

These two premises pose a mixed objective that is hard to resolve and qualifies almost all previous work on model evaluation as inadequate, because they address either the one or the other problem. Taunting the analyst even further, this assessment is easily made by visual inspection. It does not take an expert to look at a pair of maps and see whether the distribution of spatial patterns is realistic or not. The lack of formal methods and the versatility of face-validation tempt the modeller to accept the lack of objectivity and repeatability that such validation entails.

Relying on visual assessment (face validation) of model results has far-reaching consequences. Face-validation may suffice when in the initial stages of model development.; it can be expected that any 'expert' is well capable of deciding whether a model gives plausible results or not. However, once analytical tasks require many runs and evaluations the expert cannot keep up; the processes of model calibration and sensitivity analysis may require thousands of model runs. Relying on face validation also hinders the scientific discourse and the accumulation of knowledge. Differences in perspectives make it difficult to quantify progress, making it impossible to qualify model improvements or to make well-informed decisions on modelling decisions that have subtle consequences or involve trade-offs. Once established as plausible or viable, models risk remaining in an impasse where it is not clear to what extent model results can be trusted and neither how further improvements should come about. 
The Cellular Automata land use models that are the direct motivation for engaging in this research indeed satisfy both conditions, they entail complex spatial interactions and are applied to specific regions. These conditions can be found in a broad range of scientific fields however, and it is to be expected that the developed methods find applications in those fields too.

In ecology and biology there are models describing, predicting and explaining the spatial distribution of species. In many of these models there are complex relations between patterns and processes. For instance, the archetypical system dynamics model is the Lotka-Volterra or predator-prey model representing the complex interactions that arise when two populations are mutually dependent (Boyce \& DiPrima 1997). Although originally non-spatial, in recent years the consequences of spatial non-uniformity and spatial distributional aspects are investigated through simulation approaches (Wilson et al. 1993). Such models, once confronted with reality, present the same kind of challenges as land-use geosimulation models. Predictions cannot be expected to be exact and should be evaluated with a tolerance for some spatial mismatches and a focus on agreement in spatial patterns.

Also in physical geography, complex relations between pattern and process leave many phenomena best investigated on the basis of simulation. The mutual relation between geomorphology and shear stress plays a role in such diverse processes as river braiding, hill erosion, avalanches and tidal systems, river and seabed morphology. Again, the agreement of such simulation models and real processes cannot be assessed without accounting for spatial structure and a tolerance for some spatial disagreements (Cleveringa \& Oost 1999, Mulligan 1998, Murray \& Paola 1994)

In human geography, sociology and economics, interactions between people give rise to spatial dynamics. Some topics of interest investigated through simulation approaches are migration, opinion dynamics and diffusion of innovation (Phan \& Amblard 1997). Agent based simulation approaches are becoming widely applied. Here too, evaluating the models at the level of individual agents may not be as meaningful as considering the structures that emerge from the models.

Integrated assessment models typically combine models and concepts between different disciplines and find interlinkage. A typical interaction to investigate is between economic and ecological processes. Studies into sustainable exploitation of natural resources for instance consider the relation between fishery and fish-stock, water use and water supply, tourism and nature conservation. As Schneider (1997) emhasizes that integrated assessment models are always limited in their predictive power. Nevertheless their validity needs to be assessed including the degree to which the model corresponds to reality. In particular he suggests to explore the correspondence between sensitivities (responses to external events) of modelled and real processes. 


\section{Chapter 1}

Is it reasonable then to state that the concepts, methods and tools developed in this thesis are universally important for all spatial dynamic models? No, not always. There are many models that have to be evaluated while accounting for spatial structure, nevertheless the methods developed in this thesis may not be appropriate for the particular domain. For instance, meteorological models need to be evaluated in terms of the patterns that they generate, but these patterns are often well-recognized phenonema, with particular timing and trajectories that should be evaluated as such, for instance Ebert \& McBride (2000) evaluate weather forecasts on the basis of Contiguous Rain Areas.

The representation of space in this thesis suits the Cellular Automata land use models that are the primary interest. This means that geographical space will be represented by raster maps in which every cell is represented by a single legend category. Such a representation may be less adequate for models on the basis of networks, for instance road networks used in traffic simulations.

\subsubsection{Research questions}

This study aims to answer the following question and subquestions:

Question: What performance criteria can be applied to Cellular Automata land use models?

- How can map comparison methods express the agreement between reality and the model?

- How can similarity be expressed in a single objective function to support the calibration process?

- How can multiple aspects of similarity be visualized and coordinated to support a comprehensive validation process?

These questions will not only be answered in a theoretical sense, methods, guidelines and tools will be developed to be of immediate use in the process of model calibration and validation.

\subsection{Methodological approach}

\subsubsection{Local, focal and global operators}

In Geographical Information Systems (GIS) quantitative operations are classified as being local, focal or global in nature (Takeyama \& Couclelis 1997). Local statistics relate to one particular location on the map (in the case of raster maps, to a single cell). Analysis based exclusively on local operations is also called overlay analysis. Focal statistics have the focus on one location, but also take the neighbourhood of the location into account. Typical focal operations are spatial smoothing functions and density estimates. Focal operations are also called filters (typically for small neighbourhoods) or kernel 
operations (typically for large neighbourhoods). Global operations are based on aggregates over the whole map.

Spatial operations may combine local, focal and global operations. For instance the CCA model described before combines all types of operations. The different layers that constitute the potential to sustain land use classes are combined in an overlay operation (local). Of these layers, the neighbourhood effect for each cell is a function of the land use categories found in the neighbourhood (focal). The assignment of cells is based on the value of the potential relative to that of all other cells on the map (global).

In the past map comparison methods that were used as performance criteria for spatial models were either local (e.g. Monserud \& Leemans 1992; Pontius 2000) or global. Global analysis includes fractal dimension (Batty \& Longley 1994, White et al. 1997), cluster size distributions (Dungan 2006) and landscape metrics (Barredo \& Dimecheli 2003; Turner et al. 1989). The disadvantage of these methods is that either spatial structure (local) or spatial specificity (global) is ignored. Costanza (1989) circumvents this problem. He applies local operations not only to the raw model output, but also to stepwise aggregations. By these means he manages to address the continuum from local to global statistics, but at the cost of rather arbitrary units of aggregation.

The methods in this thesis consider the whole spectrum from local to global operations. The emphasis however is on focal operations. Not just because these have received little attention in the past, but primarily because focal operations are the ideal manner of investigating spatial structure while maintaining the focus on locations. The focal perspective can be considered the geographical view on spatial data, since it operationalizes the 'first law of geography': "Everything is related to everything else, but near things are more related than distant things" (Tobler 1970).

The use of focal statistics does not imply that map comparison results are only presented at the local level. By aggregating local agreement, global map comparison metrics can be calculated. Therefore a distinction is made between global map comparison based on the aggregation of local comparisons and global map comparison based on the comparison of global attributes. A distinctive characteristic is that only the former considers the degree of spatial co-variation, whereas the latter can only be used to compare maps of nonoverlapping regions.

\subsubsection{Presence and structure indicators}

The field of landscape ecology (Turner 1989) studies the relationship between landscape structure and ecological processes. One of the major contributions of the field lies in the quantification of spatial structure.

In particular two types of spatial structure are recognized: Composition and configuration. Metrics of composition are based on the fraction of occurrence of 


\section{Chapter 1}

land use / land cover classes at the global level. Examples of composition metrics are class diversity and number of classes.

Metrics of configuration relate to the spatial positioning of land use classes relative to each other. Configuration metrics are often calculated at the level of patches. Patches are contiguous areas of a class. In a geographical context patches are often called clusters. Examples of patch level structure metrics are patch size, patch perimeter, patch shape index and patch fractal dimension. Other configuration metrics that are not based on patches include the edge index and nearest neighbour index.

In landscape ecological applications, metrics are typically applied and analysed at the landscape scale, i.e. globally. When landscape metrics are applied at the focal level, the distinction between composition and configuration blurs, since the focal composition is dependent on the global configuration. Therefore, this thesis emphasizes the difference between similarity in presence and structure, but not composition and configuration.

\subsubsection{Thesis outline}

The emphasis of the thesis is on the introduction of new map comparison methods that apply focal operations to account for geographical relations in the assessment of map similarity.

Chapter 2, however, is an exception. This chapter discusses several commonly used metrics on the basis of the cell-by-cell transition table, in particular the Kappa statistic. Some methodological problems associated with recently developed variations on the Kappa statistic (Pontius 2000) which separate similarity due to quantity and location. A new Kappa variation is proposed that makes this same separation, but does not have the associated problems.

Chapter 3 introduces a 'geographical' variation of the Kappa statistic. It not only considers cell-by-cell agreement but also near agreement. Fuzzy set theory is applied to separately account for fuzziness of location and fuzziness of quantity. The globally derived metric is called the Fuzzy Kappa statistic.

The fuzzy set map comparison and the derived Fuzzy Kappa statistic have applications beyond the basic map comparison of Chapter 3. In particular the fuzziness of categories can be applied as a mechanism to weight aspects of similarity and to compare maps of unequal legends. Such applications are detailed and explored in Chapter 4.

Chapter 5 seeks to generalize and acknowledges that the fuzzy set map comparison is part of a larger family of neighbourhood based (focal) map comparison methods. It places these methods in a continuum from cell-by-cell to landscape level map comparison and details how existing methods at the local or global level can be modified to give a balanced account of similarity in presence and structure. 
The diversity of methods presented in Chapter 5 calls for an analytical framework to make results mutually comparable and to guide the interpretation. Chapter 6 offers such a framework on the basis of normalization and reference models which are neutral models of landscape change. The same chapter also applies a novel approach to multi-scale analysis based on wavelet transformation.

Chapter 7 gives a first taste of the possibilities of global comparison of map change patterns. The idea of this chapter is to evaluate models not in terms of the end state of a simulation run, but instead of the nature of the change that occur over the simulation period. Another difference with all earlier chapters is that the method is a global map comparison, meaning that change patterns of non-overlapping regions can be compared.

Finally, Chapter 8 gives conclusions and directions for further work.

Table 1.1 gives an overview on how the methods introduced and discussed in the following chapters fit in the framework of local, focal, global comparisons on the one axis and structure, presence on the other.

Table 1.1 General framework within which the comparison methods of this thesis can be classified

\begin{tabular}{llll}
\hline & Local & Focal & Global. \\
\hline Presence & Ch. 2 & Ch. 3, 4, 5,6 & Ch. 2 \\
Structure & - & Ch. 5, 6 & Ch. 7 \\
\hline
\end{tabular}





\section{Cell-by-cell comparison}

\subsection{Introduction}

Map comparison can serve many purposes For instance detection of temporal changes, accuracy assessment of map making processes, comparison of alternative model runs and scenario's. The particular purpose addressed in this chapter, and this thesis, is the evaluation of geosimulation models. For this purpose models are run for a period in the past. The level of agreement between the modelled map and the real map is then taken as the goodness-of-fit of the model.

Typically the maps that are input to the model development are produced as part of the same spatial data program as the reference maps. Furthermore the data used for spatial modelling is mostly raster based and the data in the raster maps is of a categorical nature. As a consequence the following conditions are typically satisfied:

1. The compared maps are raster maps

2. Every cell in the raster is assigned one category

3. The compared maps cover the same area

4. The maps have the same resolution.

5. The maps adhere to the same legend

There are exceptions to these rules; there are developments towards land use models that are not cell based, but operate on polygons such as cadastral parcels. Other models are based on soft classifications, i.e. cells can contain multiple land uses at different fraction. In some cases legends are not the same, because legend definitions have changed or altogether different classifications are applied. Nevertheless, the assumption of this chapter, and this thesis, is that the above conditions are true.

Considering the above restrictions the straightforward approach is to evaluate the data as a number of paired observations. Each pair consisting of a category found at a location in one map and the category found at the same location in the other map. A visual impression of map similarity can be produced by creating a third map of the same dimension, which for every pair indicates whether the categories are identical or not. Figure 2.1 shows two maps and the result of such a cell-by-cell comparison. The comparison map contains white cells where the two maps agree and black cells where they do not. 


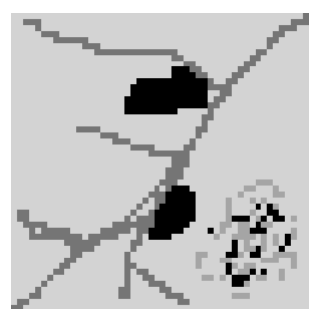

a. Map A

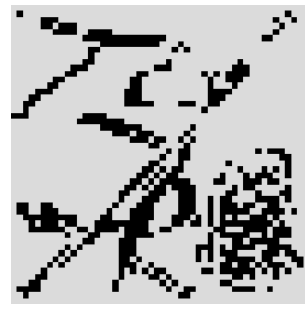

c. Comparison of map A and $\mathrm{B}$

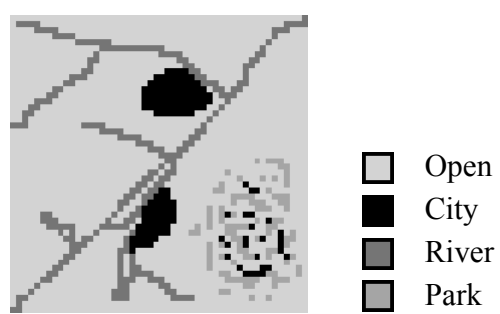

b. Map B

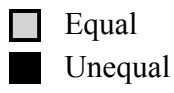

Figure 2.1 Cell-by-cell comparison of two maps

An extension of this cell-by-cell comparison is to compare separately for each category. The result of the comparison in this case is a series of maps (one for each category) that not only shows where maps agree and disagree, but also the nature of the overlap. Four classes of overlap can be distinguished:

- present in both maps

- present in neither of the maps

- present in map A not in map B

- present in map B not in map A

By not only presenting the locations of change, but also the direction and nature of the change these maps are a strong visualization of map differences as figure 2.2 illustrates.

A step further would be to map all possible types of overlap. This approach is sometimes used (e.g. Dungan 2006) but practically leads to too many classes and loss of overview. In the current example, the number of overlap types is 16 (Open to City, Open to River, Open to park, City to Open, etc.). The occurrence of such overlaps can be tabulated however, in what is called the contingency table (it is widely used and sometimes called matrix instead of table, other common names are transition, error and confusion table/matrix).

Since the contingency table, contains the full information on all possible types of overlap all imaginable cell-by-cell comparison metrics can be based on it. It is therefore recognized as a cornerstone of similarity assessment. (Foody 2002). The fraction of agreement metric for instance, can be calculated as the fraction of cells on the diagonal of the table 
The one method that is most used in spatial model assessment is the Kappa statistic, which is the same as the Heidke Skill Score (Cohen 1960, Heidke 1928, Monserud \& Leemans 1992)
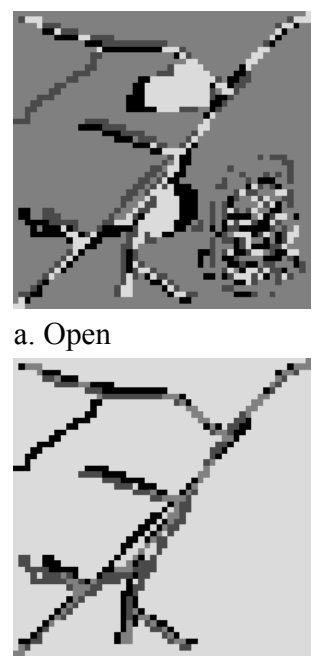

c. River

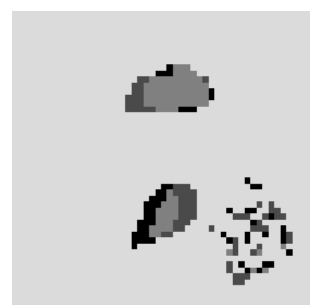

b. City

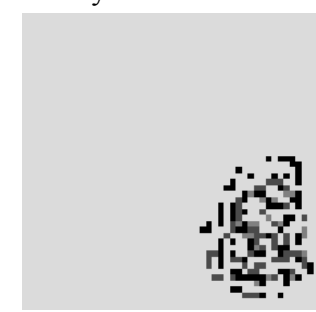

d. Park $\square$ In none of the map

In both maps

In map A, not in map B

In map A, not in map B

Figure 2.2 Per category cell-by-cell comparison of map $A$ and $B$

Table 2.1 Contingency table of map A and map $B$

\begin{tabular}{llllll}
\hline map A $\backslash$ map B & Open & City & River & Park & Total map A \\
\hline Open & 1767 & 61 & 119 & 48 & 1995 \\
City & 32 & 92 & 18 & 8 & 150 \\
River & 154 & 1 & 96 & 0 & 251 \\
Park & 74 & 11 & 0 & 19 & 104 \\
Total map B & 2027 & 165 & 233 & 75 & 2500 \\
\hline
\end{tabular}

Over time a large number of cell-by-cell metrics have been proposed. These metrics for instance discern to what extent a predicted category at a location can be expected to be correct (users accuracy) or to what extent a real category can be expected to be predicted correctly at a location (producers accuracy).

There are information based methods that do not require the compared maps to have common legend (Finn 1993; Foody 2006). Other methods account for differences in weight between different types of overlap (Næsset 1996). A regularly updated overview of such methods is maintained by Ebert (2007).

This chapter focuses on one particular method, the Kappa method. This method is most used for measuring the agreement of pairwise observations. Moreover, this chapter investigates a recent extension that separates agreement due to 


\section{Chapter 2}

location and to quantity (Pontius 2000). This separation is of particular interest for the evaluation of spatial models, because many models have separate parameters determining the total areas of categories and their spatial distribution.

The analysis will show that the metric set of Pontius (2000) produces meaningful results concerning location, but that the component for agreement due to quantity does not behave as expected and desired. Therefore an alternative formulation for this component is proposed. The method section will therefore first discuss the Kappa statistic and then Pontius' variations of the Kappa statistic aimed at distinguishing general error, location error and quantity error.

\subsection{Method}

In Pontius (2000) a number of variations of the Kappa statistic are introduced. Pontius renounces the Kappa statistic as a worthwhile measurement of similarity:

"The standard Kappa offers almost no useful information, because it confounds quantification error with location error." (Pontius 2000)

Pontius (2000) introduces two statistics that indicate the extent to which disagreement is due to location and to quantification error. These statistics are conveniently labeled as Klocation and Kquantity. The following sections first introduce the Kappa statistic and then shortly describe both of Pontius' extensions. The method section concluded by a paragraph on Khisto a newly proposed metric that serves the same purpose as Pontius' Kquantity, but does not have the same problems associated to it.

\subsubsection{Kappa statistic}

In many situations, it is preferential to express the level of agreement in a single number. The Kappa statistic is well suited to classify cell-by-cell comparisons, because it is particularly suited to compare pair wise observations (Carletta 1996, Monserud and Leemans 1992).

The essence of the Kappa statistic is that the level of agreement is corrected for the level of agreement statistically expected when randomly relocating all cells in the maps.

The reason to apply Kappa is that a part of the cell-by-cell agreement between two maps can be explained by the total number of cells taken in by the individual categories. The following simplified example illustrates this: We have a model to predict the nesting locations of ducks in a park. There are two categories for the maps: nest and non-nest. In reality, a nest will be found in only one out of a hundred cells. In this case a model that ignores the occurrence 
of nests and assumes all cells to be non-nest obtains an impressive percentage of agreement of $99 \%$, regardless the fact that it represents all nest cells incorrectly. On the other hand, a model that assumes all cells to be nests obtains a meagre percentage of agreement of $1 \%$, regardless the fact that this one represents all nests correctly. Both models have the same quality (none at all), however one scores better than the other. The reason is that the percentage of agreement "rewards" models that overestimate prevalent categories. The Kappa statistic removes this bias and returns the same similarity (zero) for both models.

One argument against using the Kappa statistic is that for a user of a map it does not matter whether accuracy is the effect of a bias or not (Stehman 2002, Turk 2002). In the process oriented task of model evaluation it is sensible however to apply such 'chance correction', because as the duck nest example makes clear a usable map does not necessarily stem from a good model. Maclure \& Willet (1987) make clear that the Kappa statistic does not remove the bias posed by the number of categories. Kappa statistics calculated for maps with different numbers of categories (legend items) are therefore not mutually comparable.

As explained in the introduction all cell-by-cell comparison metrics can be derived from the contingency table. Table 2.2 gives the generic form of this contingency table; Equations 2.2 and 2.3 use the elements of the table to calculate the actual and expected fraction of agreement.

The Kappa statistic is defined according to Equation 2.1:

$$
\mathrm{Kappa}=\frac{\mathrm{P}(\mathrm{A})-\mathrm{P}(\mathrm{E})}{1-\mathrm{P}(\mathrm{E})}
$$

where:

$\mathrm{P}(\mathrm{A}) \quad$ proportion of agreement

$\mathrm{P}(\mathrm{E}) \quad$ expected proportion of agreement.

The proportion of agreement and the expected agreement are calculated according to Equation 2.2 and Equation 2.3. Note that expected agreement is only based on the total quantities of each map.

$$
\begin{aligned}
& P(A)=\sum_{i=1}^{c} p_{i i} \\
& P(E)=\sum_{i=1}^{c} p_{i .} * p_{. i}
\end{aligned}
$$

where:

$\mathrm{p}_{\mathrm{i}} \quad$ the proportion of cells of category $\mathrm{i}$ in map A 
$\mathrm{p}_{\mathrm{i}} \quad$ the proportion of cells of category $\mathrm{i}$ in map B

$\mathrm{p}_{\mathrm{ij}} \quad$ the proportion of cells of category $\mathrm{i}$ in map $\mathrm{A}$ and category $\mathrm{j}$ in map B.,

c the number of legend entries.

Table 2.2 Proportions of agreement and disagreement, after Monserud \& Leemans (1992).

\begin{tabular}{llllll}
\hline Map A $\backslash$ Map B & 1 & 2 & $\cdots$ & $\mathrm{c}$ & Total \\
\hline 1 & $\mathrm{p}_{11}$ & $\mathrm{p}_{12}$ & & $\mathrm{p}_{1 \mathrm{c}}$ & $\mathrm{p}_{1 .}$ \\
2 & $\mathrm{p}_{21}$ & $\mathrm{p}_{22}$ & $\cdots$ & $\mathrm{p}_{2 \mathrm{c}}$ & $\mathrm{p}_{2 .}$ \\
$\vdots$ & $\vdots$ & $\vdots$ & $\ddots$ & $\vdots$ & $\vdots$ \\
$\mathrm{c}$ & $\mathrm{p}_{\mathrm{c} 1}$ & $\mathrm{p}_{\mathrm{c} 2}$ & $\cdots$ & $\mathrm{p}_{\mathrm{cc}}$ & $\mathrm{p}_{\mathrm{c.}}$ \\
Total & $\mathrm{p}_{.1}$ & $\mathrm{p}_{.2}$ & $\cdots$ & $\mathrm{p}_{. \mathrm{c}}$ & 1 \\
\hline
\end{tabular}

The consequence of the definition of Kappa is that the maximal value of 1 indicates perfect agreement. A Kappa value equal to 0 indicates that the observed agreement matches the agreement expected by random arranging of all cells. The minimum value of Kappa is -1 .

\subsubsection{Klocation}

Klocation compares the actual success rate to the expected agreement, relative to the maximum possible agreement given the total number of cells of each category. The maximum success rate is calculated according to Equation 2.4 and Klocation according to Equation 2.5.

$$
\begin{aligned}
& \mathrm{P}(\max )=\sum_{\mathrm{i}=1}^{\mathrm{c}} \min \left(\mathrm{p}_{\mathrm{i} .}, \mathrm{p}_{. \mathrm{i}}\right) \\
& \text { Klocation }=\frac{\mathrm{P}(\mathrm{A})-\mathrm{P}(\mathrm{E})}{\mathrm{P}(\max )-\mathrm{P}(\mathrm{E})}
\end{aligned}
$$

The maximum value for Klocation is 1 . There is not a minimal value. The advantage above Kappa is that Klocation is independent of the total number of cells of each category. Klocation is undefined for the special cases where $\mathrm{P}(\max )$ equals $\mathrm{P}(\mathrm{E})$. This is only the case if the categories in both maps exclude each other, or if all cells in one of the maps are taken in by one single category. Under these circumstances it is indeed not possible to make a judgment about the overlap due to location, since all spatial distributions give the same result.

Klocation values close to 1 indicate that changing the spatial distribution of the categories cannot increase the overall agreement much. Negative Klocation 
values indicate a systematic difference in location pattern. The disagreement is even larger then would be expected from random selection of locations.

Although Klocation gives an indication of the similarity of the spatial distribution of categories, the definition of spatial similarity is quite narrow. The statistic does for instance not make a distinction between a category that is dislocated over the distance of one cell, from a cell that is dislocated over the whole map. Figure 2.3 demonstrates this by presenting two sets of maps, of which the similarity of spatial allocation is clearly more similar in the first than in the second. The Klocation statistic however does not make a distinction between the two sets.

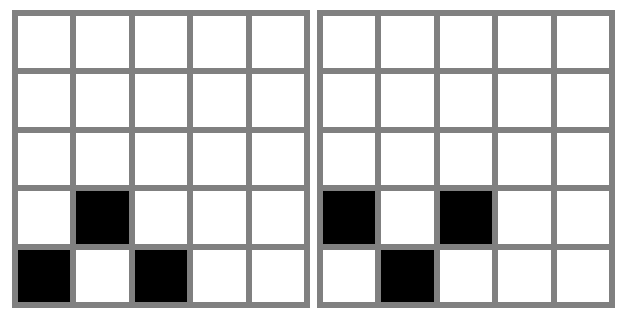

a. First set

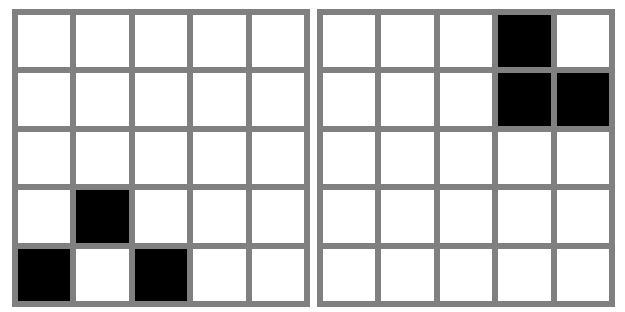

b. Second set

Figure 2.3 Two sets of maps with identical Klocation values, despite clear differences in locational similarity

\subsubsection{Kquantity}

Pontius also derived a statistic for disagreement due to quantitative difference. This is more cumbersome than for location, because it is not possible to change quantities of categories without changing the locations. It is necessary to correct both for random success and success due to good location specification.

The comparison is not symmetrical, which means that comparison of map A to map B gives different results then that of map B to map A. This means that one map has to be designated as the 'real' or template map. The other map is the 'model' or comparison map. Equation 2.6 gives the formula for Kquantity. 


$$
\text { Kquantity }=\frac{P(A)-\frac{1}{c}-\operatorname{Klocation}\left(-\frac{1}{c}+\sum_{i=1}^{c} \min \left(\frac{1}{c}, p_{i .}\right)\right)}{\sum_{i=1}^{c} p_{i .}{ }^{2}-\frac{1}{c}-\operatorname{Klocation}\left(-\frac{1}{c}+\sum_{i=1}^{c} \min \left(\frac{1}{c}, p_{i} .\right)\right)}
$$

The complicated form of Equation 2.6 obscures its interpretation, but some small experiments expose different problems:

\section{Stability problem}

The following contingency tables are highly similar, only one cell has been replaced. Nevertheless, the Kquantity statistic changes extremely.

Table 2.3 Two contingency tables illustrating the stability problem

a. First contingency table

\begin{tabular}{llll}
\hline & A & B & Total \\
\hline A & 2 & 21 & 23 \\
B & 20 & 22 & 42 \\
Total & 22 & 43 & 65 \\
\hline
\end{tabular}

b. Second contingency table with a small deviation from the first table

\begin{tabular}{llll}
\hline & A & B & Total \\
\hline A & 2 & 22 & 23 \\
B & 20 & 21 & 42 \\
Total & 22 & 43 & 65 \\
\hline
\end{tabular}

c. Kappa results, indicating the instability of Kquantity

\begin{tabular}{lll}
\hline & First & Second \\
\hline Kappa & -0.39 & -0.41 \\
Klocation & -0.41 & -0.44 \\
Kquantity & 20.89 & -2 \\
\hline
\end{tabular}

\section{Symmetry problem}

The following example demonstrates that Kquantity is not symmetrical. Two contingency tables that are transposed, but otherwise identical cause different Kquantity statistics. There is no difference for Kappa, Kno and Klocation.

Table 2.4 Two contingency tables illustrating the symmetry problem

a. First contingency table

\begin{tabular}{llll}
\hline & A & B & Total \\
\hline A & 2 & 7 & 9 \\
B & 6 & 25 & 31 \\
Total & 8 & 32 & 40 \\
\hline
\end{tabular}

b. Second contingency table, transposition of the first table

\begin{tabular}{llll}
\hline & A & B & Total \\
\hline A & 2 & 6 & 8 \\
B & 7 & 25 & 32 \\
Total & 9 & 31 & \\
\hline
\end{tabular}

c. Kappa results, indicating asymmetry of Kquantity

\begin{tabular}{lll}
\hline & First & Second \\
\hline Kappa & 0.03 & 0.03 \\
Klocation & 0.03 & 0.03 \\
Kquantity & 1.08 & 0.92 \\
\hline
\end{tabular}

\section{Values out of range problem}

The examples give in above also illustrate that Kquantity may also take values above one. This is unexpected because Kquantity $=1$ already means perfect similarity of quantity. 


\subsubsection{Khisto}

An alternative expression for the similarity of the quantitative model results is the maximal similarity that can be found based upon the total number of cells taken in by each category. This is already introduced as $\mathrm{P}(\max ) . \mathrm{P}(\max )$ can be put in the context of Kappa and Klocation by scaling it to $\mathrm{P}(\mathrm{E})$. The resulting statistic is newly introduced here and is called Khisto, because it can be calculated directly from the histograms of two maps. Khisto is defined by Equation 2.7.

$$
\text { Khisto }=\frac{P(\max )-P(E)}{1-P(E)}
$$

The definition of Khisto has the powerful property that Kappa is now defined as the product of Klocation and Khisto (Equation 2.8). Here, Klocation is a measure for the similarity of spatial allocation of categories of the two compared maps, and Khisto is a measure for the quantitative similarity of the two compared maps.

$$
\text { Kappa }=\text { Khisto } * \text { Klocation }
$$

Equation 2.8

\subsubsection{Kappa statistics per category}

Instead of calculating Kappa statistics for all categories combined, there is the option to calculate Kappa statistics per category. To do so the contingency table is reduced to a contingency table with only two categories, the first is the category of interest (category i). The second category in the reduced contingency table combines all other categories. This approach is also applied in Monserud \& Leemans (1992), albeit only for the Kappa statistic and not for its variations. Table 2.5 gives the reduced contingency table.

Table 2.5 Reduced contingency table for a single category

\begin{tabular}{llll}
\hline Map A $\backslash$ Map B & Category $\mathrm{i}$ & All others & Total \\
\hline Category $\mathrm{i}$ & $\mathrm{p}_{\mathrm{ii}}$ & $\mathrm{p}_{\mathrm{i} .}-\mathrm{p}_{\mathrm{ii}}$ & $\mathrm{p}_{\mathrm{i} .}$ \\
All others & $\mathrm{p}_{\mathrm{i} .}-\mathrm{p}_{\mathrm{ii}}$ & $1-\mathrm{p}_{\mathrm{i} .-} \mathrm{p}_{\mathrm{i}+} \mathrm{p}_{\mathrm{ii}}$ & $1-\mathrm{p}_{\mathrm{i} .}$ \\
Total & $\mathrm{p}_{. \mathrm{i}}$ & $1-\mathrm{p}_{\mathrm{i}}$ & 1 \\
\hline
\end{tabular}

The following equations give the different Kappa variations for category i, except for Kquantity. In accordance with the overall statistics the following relationship applies: $\mathrm{Kappa}_{\mathrm{i}}=\mathrm{Klocation}_{\mathrm{i}}{ }^{*} \mathrm{Khisto}_{\mathrm{i}}$. 


$$
\begin{aligned}
& \operatorname{Kappa}_{\mathrm{i}}=\frac{\mathrm{p}_{\mathrm{ii}}-\mathrm{p}_{\mathrm{i} . \mathrm{.i}} \mathrm{p}_{\mathrm{i}}}{\frac{1}{2}\left(\mathrm{p}_{\mathrm{i} .}+\mathrm{p}_{. \mathrm{i}}\right)-\mathrm{p}_{\mathrm{i} . \mathrm{p}_{. i}}} \\
& \text { Klocation }_{\mathrm{i}}=\frac{\mathrm{p}_{\mathrm{ii}}-\mathrm{p}_{\mathrm{i} . \mathrm{p}_{. i}}}{\min \left(\mathrm{p}_{\mathrm{i} .}, \mathrm{p}_{. \mathrm{i}}\right)-\mathrm{p}_{\mathrm{i} . \mathrm{.i}} \mathrm{p}_{. \mathrm{i}}} \\
& \text { Khisto }_{\mathrm{i}}=\frac{\min \left(\mathrm{p}_{\mathrm{i} .}, \mathrm{p}_{. \mathrm{i}}\right)-\mathrm{p}_{\mathrm{i} .} \mathrm{p}_{. \mathrm{i}}}{\mathrm{p}_{\mathrm{ii}}-\mathrm{p}_{\mathrm{i} .} \mathrm{p}_{. \mathrm{i}}}
\end{aligned}
$$

Equation 2.11

\subsubsection{Reference level}

The correction for agreement due to chance agreement is important for removing bias. Too often, however, the chance agreement is interpreted as a reference level. In reality it has limited meaning as such. The Kappa statistic is not suitable to directly pass judgment on model results; a Kappa result well above zero signifies a level of agreement that is clearly better than expected from random map making, however in the context of model validation this does not necessarily imply a good model. In fact, a Kappa result indicating a good result in one case may indicate a bad result in another, simply because the criterion that the similarity level must be higher than what can be expected from random map generation is in many cases too lenient. Often there is better a reference available specifically relevant to the situation at hand.

It can for instance be worthwhile to use historical maps as a reference. For instance a model simulates from 1950 to 1980 . The results are compared with real data from 1980; in this case it would be more informative to know how the model performs relative to the base data of 1950, rather than to some random generated map. Figure 2.4 schematically illustrates a procedure to do this. Chapter 6 gives a more elaborate methodology for creating and applying reference maps.

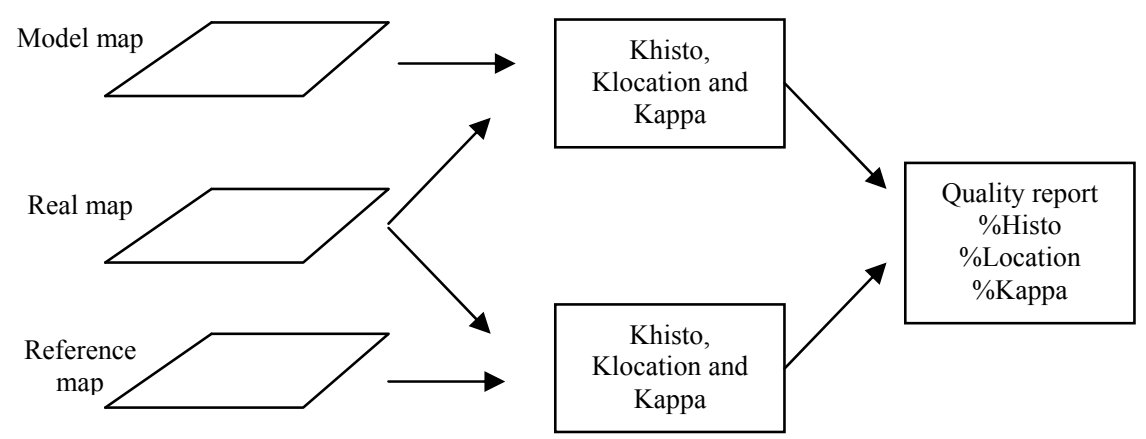

Figure 2.4 Scheme for using reference map comparison with Kappa statistic 


\subsection{Results}

The use of the Kappa variants is investigated by applications to two test cases. Both test cases have been made available by National Institute for Public Health and the Environment and come from models that try to foresee changes in the environment.

The first case is the EUROMOVE model (Bakkenes et al. 2002) this model seeks to give insight in the consequences of climate change with regards to the diversity and distribution of species. The model applies multiple logistic regression in order to predict the pattern of occurrence of approximately 1400 plant species in the year 2050. The test case in this paper only addresses one of these species and evaluate the fit of the logistic model, in other words it does not consider the predicted map of 2050, but instead compares the predicted distribution in 1990 with the actual distribution in 1990.

The second case is the Environment Explorer (Engelen et al. 2003), which is a Planning Support System built around a constrained Cellular Automata land use model. The system is used to explore the long term development of land use patterns and the associated social, economical and ecological consequences as a result of national spatial planning strategies and expected national population and employment developments. Typically the end year of simulations is 2030 . For the current case the model compares the results of a simulation run from 1989 to 1996 to the actual situation in 1996.

\subsubsection{Case A: EUROMOVE}

The EUROMOVE model (Bakkenes et al. 2002) predicts the occurrence of a wide range of plant species and is amongst others calibrated upon the occurrence of the species Hymenophyllum wilsonii. The dataset depicts the occurrence of this species in 1990 as observed in the Atlas Florae Europaeae (AFE) and the occurrence in 1990 according to the EUROMOVE model (EMM). For the sake of the exercise described in this report, the datasets have been slightly modified from the original data. The maps have been reduced in size by leaving out a large area of NoData values in the Atlantic Ocean and the maps have been aligned by assigning cells having the NoData value in one of the maps also the NoData value in the other map.

Besides the whole study area (Europe) also several subsets of the area are considered. In the maps of figure 2.5 black cells indicate the presence of a species of plants (Hymenophyllum wislonii). The maps labeled AFE are based upon the Atlas Florea Europaeae, the maps labeled EMM result from the EUROMOVE model. Table 2.6 gives corresponding contingency tables. 
Chapter 2
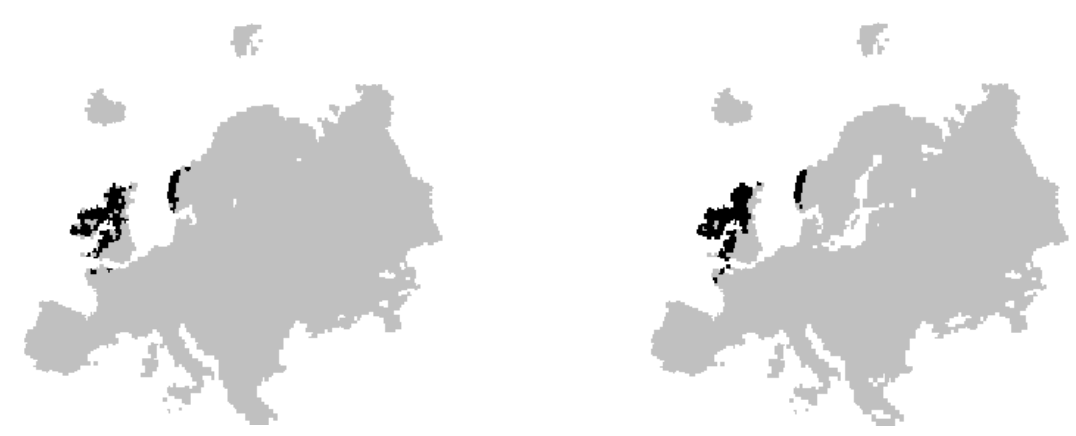

a. Europe

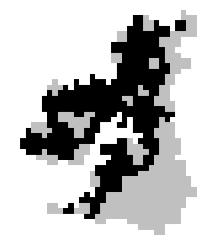

b UK \& Ireland

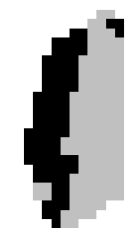

d. SW Norway
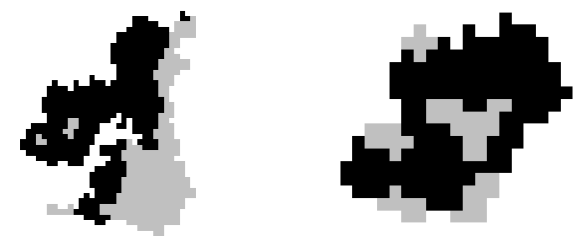

c. Ireland

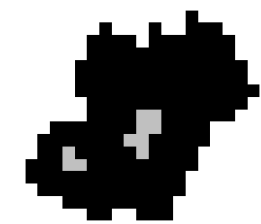

$\square$ Species present
$\square$ Species absent
$\square$ Nodata

Figure 2.5 Atlas Flora Europaeae (left) and EuroMove (right) dataset and three subsets,.

Table 2.6 Contingency tables corresponding to the maps in figure 2.5

a. Europe

\begin{tabular}{llll}
\hline AFE\EMM & Yes & No & Total \\
\hline Yes & 415 & 111 & 526 \\
No & 66 & 16861 & 16927 \\
Total & 481 & 16972 & 17453 \\
\hline c. Ireland & & & \\
\hline AFE\EMM & Yes & No & Total \\
\hline Yes & 135 & 6 & 141 \\
No & 45 & 4 & 49 \\
Total & 180 & 10 & 190 \\
\hline
\end{tabular}

b. UK \& Ireland

\begin{tabular}{|c|c|c|c|}
\hline AFE\EMM & Yes & No & Total \\
\hline Yes & 344 & 42 & 386 \\
\hline No & 98 & 245 & 343 \\
\hline Total & 442 & 287 & 729 \\
\hline \multicolumn{4}{|l|}{ d. SW Norway } \\
\hline AFE\EMM & Yes & No & Total \\
\hline Yes & 68 & 16 & 84 \\
\hline No & 0 & 139 & 139 \\
\hline Total & 68 & 155 & 223 \\
\hline
\end{tabular}


Table 2.7 Kappa statistics corresponding to the maps in figure 2.5

\begin{tabular}{lllll}
\hline & Europe & UK+Ireland & Ireland & SW-Norway \\
\hline Kappa & 0.82 & 0.61 & 0.05 & 0.84 \\
Klocation & 0.85 & 0.72 & 0.19 & 1.0 \\
Khisto & 0.95 & 0.84 & 0.28 & 0.84 \\
Kquantity A-B & 0.996 & -1.5 & 1.3 & 0.42 \\
Kquantity B-A & 0.995 & 0.28 & 0.54 & 0.63 \\
\hline
\end{tabular}

The results in table 2.7 demonstrate that the drawbacks of the Kquantity are not just hypothetical, but manifest themselves in a practical application. It is a-symmetric and also returns unexpected results above the value 1 . The Norway map yields an extreme result of Klocation equals 1 . This means that for this section of the map it is only possible to increase similarity by adjusting the total presence of the species.

For the similarity of Europe a Khisto value of 0.95 is found, this indicates that quantification is close to perfect. An eventual overall (Kappa) improvement is more likely to be found in improvement in the spatial differentiation than in the quantification. This conclusion is not surprising since the calibration process involved optimization of the Kappa statistic by changing the overall presence of species, as the following citation explains: "As the results of regression equations are in terms of probability and we want to count the number of species, the probabilities had to be transformed to species' predicted presences or absences. For each species we derive a specific threshold probability above which we assume the species to be present. [...] For each individual species the threshold value was set at the value that maximized the Kappa statistic, leading to an optimal match between observed and predicted occurrence". (Bakkenes et al. 2002)

\subsubsection{Case B: Environment Explorer}

The Environment Explorer is a Constrained Cellular Automata land-use model of the Netherlands (Engelen et al. 2003). Three maps are available (see figure 2.6).

1. observed map of 1989 (lovbk89)

2. observed map of 1993 (lovbk93)

3. simulated map of 1993 (lu93_sim)

All maps have the same size; 540 columns by 650 rows and the cell size is 500 m. 


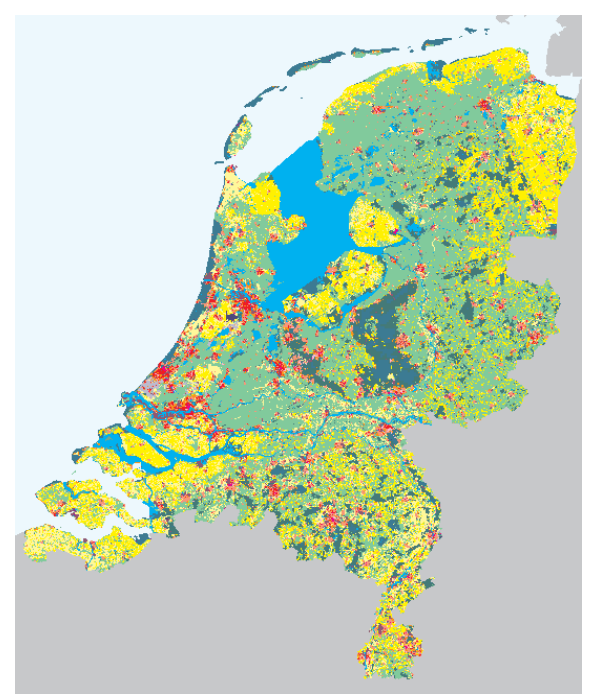

a. Land use in 1989

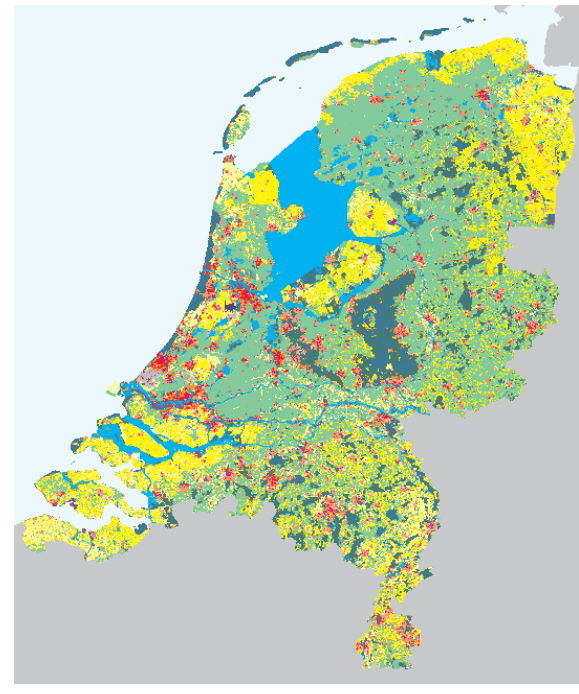

c. Simulated land use in 1993

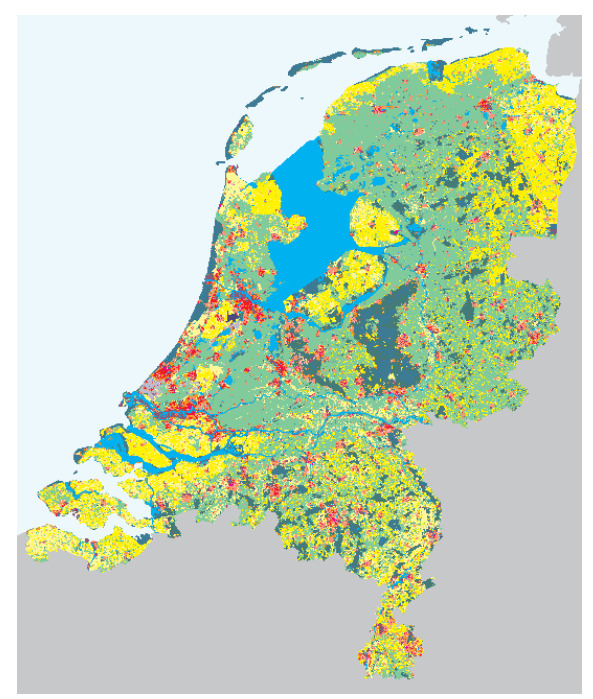

b. Land use in 1993

$\begin{array}{ll}\square & \text { Other agriculture } \\ \square & \text { Grassland } \\ \square & \text { Arable land } \\ \square & \text { Greenhouses } \\ \square & \text { Sparse residential } \\ \square & \text { Dense residential } \\ \square & \text { Industry } \\ \square & \text { Commercial } \\ \square & \text { Other services } \\ \square & \text { Forest } \\ \square & \text { Extensive grassland } \\ \square & \text { Nature } \\ \square & \text { Recreation } \\ \square & \text { Airport } \\ \square & \text { Fresh water } \\ \square & \text { Salt water } \\ \square & \text { Foreign }\end{array}$

Figure 2.6 Environment Explorer dataset

Table 2.8 gives the results of Kappa statistics for the overall map and per category for the Environment Explorer results (lovbk93 compared to lu93_sim). The category Foreign has been left out of the analysis, because it is not part of the study area. All discussed Kappa variations are presented. Considering the before mentioned reservation on Kquantity, the interpretation is limited to Kappa, Klocation and Khisto. The results indicate that the largest differences can be found in categories Commercial, Other services, Extensive grassland. 
These are the only categories with a Kappa value below 0.8 . Commercial has a relatively low value for Klocation this indicates that the cause of the high difference lays in the spatial location. For category Other services both Klocation and Khisto are relatively low, for this category the difference is caused by a combination of quantitative differences and different spatial location. The low Kappa for Extensive grassland is best explained by differences in quantity as indicated by the low value for Khisto.

An overall Kappa value of 0.974 is observed. This indicates very good agreement according to a table presented by Monserud \& Leemans (1992). It is not evident however, that the classification used in that article is also applicable for the current situation. In order to give an indication of the quality of the model a reference level is needed. The procedure involving a reference map has been followed for the Environment Explorer results. Chapter 6 will provide a more thorough approach to creating and applying reference maps. In this case, the 1989 base data (lovbk89) is used as a reference map, results are found in figure 2.7

Table 2.8 Kappa results for the Environment Explorer, the simulated and observed maps for 1993 are compared

\begin{tabular}{llllll}
\hline & Kappa & Klocation & Khisto & Kquantity1 & Kquantity2 \\
\hline Overall & 0.97 & 0.98 & 0.99 & 0.99 & 0.99 \\
Other agriculture & 0.90 & 0.91 & 0.99 & 1.00 & 1.00 \\
Grassland & 0.97 & 0.98 & 0.99 & 0.99 & 0.99 \\
Arable land & 0.98 & 0.98 & 1.00 & 1.00 & 1.00 \\
Greenhouses & 0.81 & 0.84 & 0.96 & 1.00 & 1.00 \\
Sparse residential & 0.95 & 0.95 & 1.00 & 1.00 & 1.00 \\
Dense residential & 0.94 & 0.95 & 1.00 & 1.00 & 1.00 \\
Industry & 0.85 & 0.87 & 0.98 & 1.00 & 1.00 \\
Commercial & 0.80 & 0.81 & 0.98 & 1.00 & 1.00 \\
Other services & 0.78 & 0.86 & 0.91 & 1.00 & 1.00 \\
Forest & 0.96 & 0.97 & 0.99 & 1.00 & 1.00 \\
Extensive grassland & 0.73 & 0.91 & 0.80 & 1.00 & 1.00 \\
Nature & 0.91 & 0.95 & 0.96 & 1.00 & 1.00 \\
Recreation & 0.87 & 0.87 & 1.00 & 1.00 & 1.00 \\
Airport & 0.91 & 0.97 & 0.94 & 1.00 & 1.00 \\
Fresh water & 0.97 & 0.97 & 1.00 & 1.00 & 1.00 \\
Salt water & 1.00 & 1.00 & 1.00 & 1.00 & 1.00 \\
\hline
\end{tabular}

Given the small changes in land use occurring over a period of four years, the 1989 base data presents an ambitious reference level. It is expected that results that are validated according to this method will look better if the time between 


\section{Chapter 2}

the reference and the model date is larger. The results of a validation over a longer model period, e.g. twenty years will also be more interesting. Because, the results as presented here merely indicate that in four years time land use hardly changes both in the observed reality and in the model.

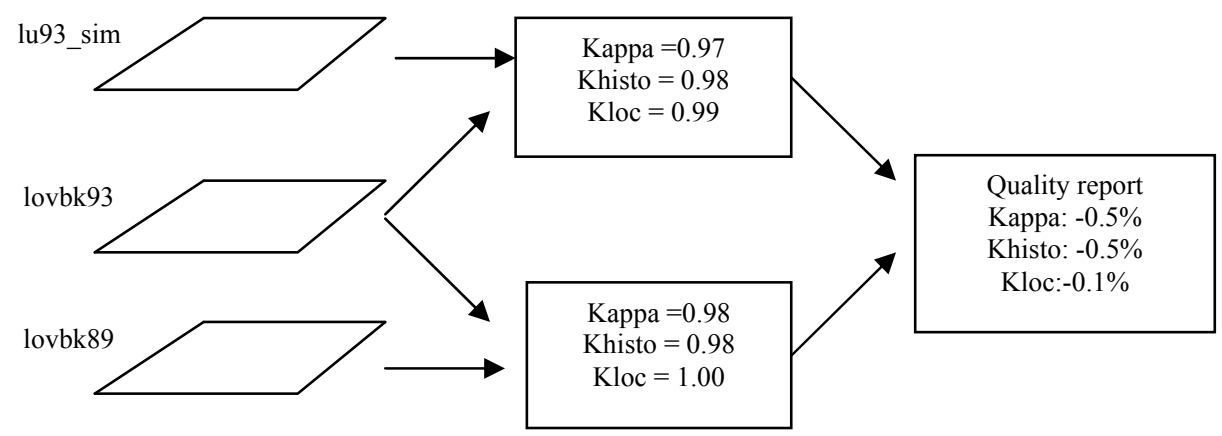

Figure 2.7 Comparison scheme applied for Environment Explorer

It is suggested (pers. com. Guy Engelen) that a relatively large part of the dissimilarity can be explained by misrepresentations within the 'green' land use types. A new contingency table is constructed in which the 'green' land use types are collapsed.

Table 2.9 Green land use types

\begin{tabular}{ll}
\hline Category & Description \\
\hline 0 & Other agriculture \\
1 & Grassland \\
2 & Arable land \\
9 & Forest \\
10 & Extensive grassland \\
11 & Nature \\
12 & Recreation \\
\hline
\end{tabular}

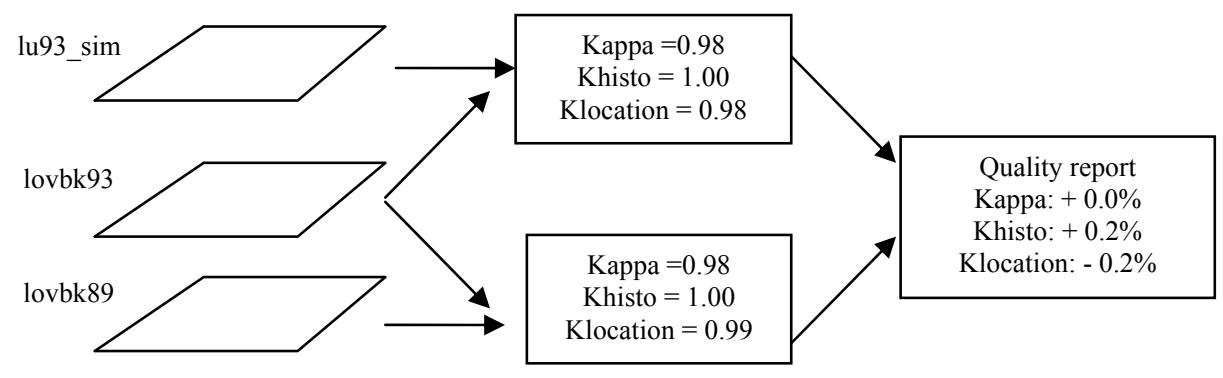

Figure 2.8 Comparison scheme applied for Environment Explorer with collapsed categories 


\subsection{Conclusion}

This chapter discusses cell-by-cell comparison methods that are used for as performance criteria of spatial model. These methods represent the state of the art in spatial accuracy assessment (Foody 2002). The realization that all cell-bycell methods can be derived from the contingency table is a warning flag; These methods do not offer map comparison in a geographical sense, since except for co-occurrence there is no notion of distance or spatial structure at all.

Despite the lack of a geographical perspective, cell-by-cell methods have their attractions as well. The methods are easily implemented, widely applied and unambiguous. As the methods and cases in this chapter demonstrated different aspects of map similarity can be evaluated; Different degrees of similarity can be attributed to individual legend categories and the distinction between agreement due to quantity and location is made.

Such detailed assessment is most useful in the process of model calibration. Understanding of the nature of the errors guides the calibration process (either automatic or manual) and can lead to faster convergence. This advantage is most clear when the calibrated model has parameters that are particular to individual categories. Likewise the distinction between Klocation and Khisto is useful when different parameters govern the quantities of categories and their spatial distribution.

Even though the formulation of the Kappa statistic suggests that the level expected agreement is used as a benchmark, interpretation as such may be misleading. The purpose of accounting (correcting) for the expected agreement is to resolve a bias. In many cases it is not an appropriate benchmark level for goodness-of-fit. The literature offers tables or rules of thumb that relate Kappa values to a validation judgment, these are of no value in the case of evaluation of dynamic models. The Environment Explorer case demonstrates that Kappa values as high as 0.98 may still be below the level of aspiration. The need to establish appropriate reference levels will surface repeatedly in this thesis and will be addressed in depth in chapter 6 . 



\section{Fuzzy set map comparison}

\subsection{Introduction}

For most purposes visual, human comparison still outperforms automated procedures. When comparing maps the human observer takes many aspects into consideration without deliberately trying. Local similarities, but also global similarities, logical coherence, patterns etc. are recognized. Map comparison methods performed by software usually capture one of these aspects, but overlook the others. Furthermore, they generally lack the flexibility to switch from one aspect to the other when the data requires so. The best example of this rigidity is the cell-by-cell comparison of two checkerboards; the first board has a white field in the upper left corner, the second a black field. The average observer would immediately recognize the two boards as being highly similar in quality, however a cell-by-cell comparison method would find a black cell where a white one is expected and vice versa. Hence total disagreement would be concluded.

The comparison method presented here, is primarily developed to be of use in the calibration and validation process of cellular models for land-use dynamics. The method is based on fuzzy set theory (Bandemer \& Gottwald 1995, Zadeh 1965). Several authors addressed the potential of fuzzy set theory for geographical applications (Cheng et al. 2001; Fisher 2000) and fuzzy set theory has been used before to assess the accuracy of map representations and for map comparisons (Lewis \& Brown 2001, Metternicht 1999, Power et al. 2001).

The subject of map comparison is closely related to accuracy assessment of maps, in the sense that accuracy assessment is one of its applications. Foody (2002) presents an overview of the status of land cover classification accuracy assessment. Several issues that are brought to attention in that overview are, at least partly addressed in this chapter. Foody (2002) asks: "Why cannot some level of positional tolerance be more generally incorporated into thematic map accuracy assessment". Also, he stresses that "spatial variability of error can be a major concern". Finally Foody (2002) states that there is "scope for considerable research" on the topic of fuzzy classifications in accuracy assessment.

The objective is to find a method that to some extent mimics the human comparison and gives a detailed assessment of similarity. The method is aimed 
at comparing categorical raster maps. The assessment results are spatial and gradual; additionally an overall figure for similarity is aggregated from the detailed spatial results.

\subsection{Method}

For the comparison of maps, two sources of fuzziness are considered: fuzziness of location and fuzziness of category. A similar distinction is found in (Cheng et al. 2000), where thematic and geometric aspects of uncertainty are treated separately. In this chapter, fuzziness means a level of uncertainty and vagueness of a map. This fuzziness is not inherently present in the map, but follows from an observer's interpretation. Here fuzziness of category means that some categories in the legend of a map are more similar to each other than others. Fuzziness of location means that the spatial specification found in a categorical map is not always as precise as appears. A category that in the map is positioned at a specific location may be interpreted as being present somewhere in the proximity of that location.

In the original map every cell is represented by a single category. In the fuzzy representation a cell will partially belong to multiple categories. To allow cells to belong to multiple categories simultaneously they are assigned a membership vector. The elements of the vector give the degree of belonging to each category. In this chapter three types of membership vectors will be distinguished the Crisp Vector $\left(\mathrm{V}_{\text {crisp }}\right)$ the Fuzzy Category Vector $\left(\mathrm{V}_{\text {cat }}\right)$ and the Fuzzy Neighbourhood Vector $\left(\mathrm{V}_{\mathrm{nbh}}\right)$. The Crisp Vector does not involve fuzziness at all. The Fuzzy Category Vector represents a cell when only fuzziness of category is considered. Finally, the Fuzzy Neighbourhood Vector represents a cell considering fuzziness of both category and location.

The Crisp Vector simply transforms the categories of the legend into vector notation. All element in the vector have value 0 except for the element corresponding to the category itself, which gets value 1 . Table 3.1 gives an example for a map containing four categories.

Table 3.1 Crisp Vector representation of four categories

\begin{tabular}{lll}
\hline Category & Original representation & Crisp Vector \\
\hline Urban area & 1 & $(1,0,0,0)$ \\
Undeveloped & 2 & $(0,1,0,0)$ \\
Agriculture & 3 & $(0,0,1,0)$ \\
Water & 4 & $(0,0,0,1)$ \\
\hline
\end{tabular}




\subsubsection{Representation of fuzziness of categories}

Vagueness may exist in the definition of categories. This is especially true if some or all categories on the map have in fact an ordinal definition, such as for instance the categories 'high-', 'medium-'and 'low-density residential area' on a land use map.

Similarity between categories is expressed in the Fuzzy Category Vector by assigning a higher degree of membership for categories that are more similar to the original category. Each element in the vector has a value between 0 (no similarity) and 1 (undistinguishable). A category is undistinguishable from itself, thus the degree of membership for the element corresponding to the category itself is 1 .

Table 3.2 demonstrates by example how the fuzziness of the categories can be expressed in the Fuzzy Category Vector. The meaning of this particular fuzzy representation of categories is that, for instance, 'low density residential' is considered more similar to 'high density residential' than to 'industry'. On the other hand 'low density residential' is less similar to 'high density residential' to than 'medium density residential'.

Table 3.2 Fuzzy representation of ordinal data

\begin{tabular}{llllllllll}
\hline Category & Number & \multicolumn{1}{l}{ Fuzzy Category Vector } & & & \\
\hline High density residential & 1 & ( & 1 & 0.4 & 0.2 & 0 & 0 & 0 & ) \\
Medium density residential & 2 & ( & 0.4 & 1 & 0.4 & 0 & 0 & 0 & ) \\
Low density residential & 3 & ( & 0.2 & 0.4 & 1 & 0 & 0 & 0 & ) \\
Agriculture & 4 & ( & 0 & 0 & 0 & 1 & 0 & 0 & ) \\
Industry & 5 & ( & 0 & 0 & 0 & 0 & 1 & 0 & ) \\
Water & 6 & ( & 0 & 0 & 0 & 0 & 0 & 1 & ) \\
\hline
\end{tabular}

In the previous example it is clear that 'high-', 'medium-' and 'low-density residential' are sub-categories of 'residential'. Maps will more often contain a mixture of categories and sub-categories. The sub-categories are not always ordinal; they can also be nominal. The difference between categories in the legend that are sub-categories of the same main category is often less distinct than between categories that do not belong to a common group of categories. This can also be expressed in the Fuzzy Category Vector, as is illustrated by an example in table 3.3 
Chapter 3

Table 3.3 Fuzzy representation of hierarchical data

\begin{tabular}{llllllllll}
\hline Category & Number & Fuzzy Category Vector & & & \\
\hline Residential & 1 & ( & 1 & 0 & 0 & 0 & 0 & 0 & ) \\
Citrus agriculture & 2 & ( & 0 & 1 & 0.3 & 0.3 & 0 & 0 & ) \\
Sugarcane agriculture & 3 & ( & 0 & 0.3 & 1 & 0.3 & 0 & 0 & ) \\
Banana agriculture & 4 & ( & 0 & 0.3 & 0.3 & 1 & 0 & 0 & ) \\
Industry & 5 & ( & 0 & 0 & 0 & 0 & 1 & 0 & ) \\
Water & 6 & ( & 0 & 0 & 0 & 0 & 0 & 1 & ) \\
\hline
\end{tabular}

In the example of table 3.3 the sub-categories 'citrus-', 'sugarcane-' and 'banana agriculture' are considered more similar to each other than to the other categories, 'residential', 'industry' and 'water'.

It should be kept in mind that the fuzzy representation is in reality an interpretation of the original crisp data. There are no straightforward rules for assigning membership values. The definition of the appropriate set depends, for instance, on the nature of the map, the aim of the comparison and the number of categories present This realization .

\subsubsection{Representation of fuzziness of location}

Besides fuzziness of category also fuzziness of location is considered. The calculation of fuzziness of location is based upon the notion that the fuzzy representation of a cell depends on the cell itself and, to a lesser extent, also the cells in its neighbourhood. The extent to which the neighbouring cells influence the fuzzy representation is expressed by a distance decay function. For instance a cone (defined by radius), an exponential decay (defined by halving distance) or a 3-D Gausse curve (defined by variance), see figure 3.1 (Bandemer \& Gottwald 1995).

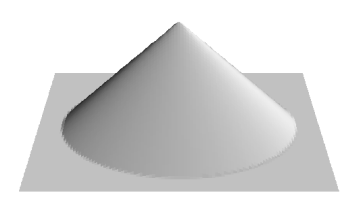

a. Cone

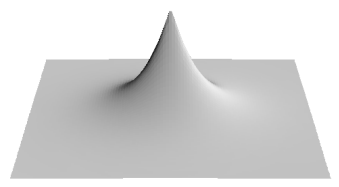

b. Exponential

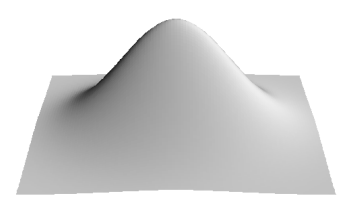

c. Gaussian

Figure 3.1 Some 3D memberships

Which function is most appropriate and also the size of the neighbourhood depends on the nature of the uncertainty, vagueness of the data and the observer's tolerance for spatial error. From a theoretical point of view, there is 
not a best alternative, hence it is worthwhile to experiment with size and form of the function.

The different membership contributions of the neighbouring cells are combined by calculating the fuzzy union of all neighbouring cells multiplied by the weight corresponding to their distance. The vector that results from this operation is the Fuzzy Neighbourhood Vector Equation 3.1

$$
\mu_{\mathrm{nbh}, \mathrm{i}}=\underset{\mathrm{j}=1}{\mathrm{n}}\left|\mathrm{w}_{\mathrm{j}} * \mu_{\mathrm{cat}, \mathrm{i}, \mathrm{j}}\right|
$$

where:

$\mu_{\text {nbh,i }} \quad$ i-th element of Fuzzy Neighbourhood Vector $\left(V_{n b h}\right)$

$\mu_{\text {cat }, i, j} \quad i$-th element of the Fuzzy Category Vector $\left(V_{\text {cat }}\right)$ of the $j$-th cell in the neighbourhood.

$w_{j} \quad$ distance based membership of $j$-th cell in the neighbourhood

$\mathrm{n}$ number of cells in the neighbourhood

Figure 3.2 and Equation 3.2 illustrate this for a cell in a neighbourhood with a radius of $\sqrt{ } 2$ cells. The figure describes the situation. Equation 3.2 applies Equation 3.1 for the central cell of the particular situation.

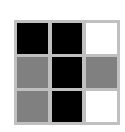

a. Neighbourhood

\begin{tabular}{ll}
\hline category & Fuzzy Category Vector \\
\hline black & $(1,0,0)$ \\
white & $(0,1,0)$ \\
grey & $(0,0,1)$ \\
\hline
\end{tabular}

b. Legend

\begin{tabular}{ll}
\hline $\mathrm{d}$ & $\mathrm{w}$ \\
\hline 0 & 1 \\
1 & 0.5 \\
$\sqrt{ } 2$ & 0.2 \\
\hline
\end{tabular}

c. Distance relation

Figure 3.2 Neighbourhood, legend and distance relation

$$
\mathrm{V}_{\text {nbh }}=\left(\begin{array}{c}
\operatorname{Max}\left[\begin{array}{lll}
1 * 0.2 & 1 * 0.5 & 0 * 0.2 \\
0 * 0.5 & 1 * 1.0 & 0 * 0.5 \\
0 * 0.2 & 1 * 0.5 & 0 * 0.2
\end{array}\right] \\
\operatorname{Max}\left[\begin{array}{lll}
0 * 0.2 & 0 * 0.5 & 1 * 0.2 \\
0 * 0.5 & 0 * 1.0 & 0 * 0.5 \\
0 * 0.2 & 0 * 0.5 & 1 * 0.2
\end{array}\right] \\
\operatorname{Max}\left[\begin{array}{lll}
0 * 0.2 & 0 * 0.5 & 0 * 0.2 \\
1 * 0.5 & 0 * 1.0 & 1 * 0.5 \\
1 * 0.2 & 0 * 0.5 & 0 * 0.2
\end{array}\right]
\end{array}\right)=\left(\begin{array}{l}
1 \\
0.2 \\
0.5
\end{array}\right)
$$


In the example of figure 3.2, the Fuzzy Category Vector is equal to the Crisp Vector, indicating that similarity between categories has not been considered. The procedure is identical if the Fuzzy Category Vector does express similarity between categories.

\subsubsection{The comparison}

\section{Comparison of two fuzzy cells}

The similarity of two maps can be assessed by cell-by-cell comparison of the fuzzy vectors assigned to all cells. The expression for similarity at each location is based upon the fuzzy set intersection of the two fuzzy vectors, and is given in Equation 3.3.

$$
\mathrm{S}\left(\mathrm{V}_{\mathrm{A}}, \mathrm{V}_{\mathrm{B}}\right)=\max _{\mathrm{i}=1}^{\mathrm{c}}\left|\min \left(\mu_{\mathrm{A}, \mathrm{i}}, \mu_{\mathrm{B}, \mathrm{i}}\right)\right|
$$

Equation 3.3

In Equation 8, $\mathrm{S}\left(\mathrm{V}_{\mathrm{A}}, \mathrm{V}_{\mathrm{B}}\right)$ stands for the similarity between a cell in map $\mathrm{A}$ and one at the same location in map B. In (Zadeh 1965) the same expression is indicated by the letter $\mathrm{M}$ and referred to as the 'maximal degree of intersection A $\cap$ B'. This index is chosen, despite the availability of many alternatives (Shyi-Ming 1995, Tolias et al. 2001, Wang et al. 1995, Zwick et al. 1987). The reason for this choice is that, when applied according to the two-way method described in the following section it behaves just as intended, as will be illustrated.

Equation 3.3 calculates the similarities if the Fuzzy Neighbourhood Vectors of the two central cells found in figure 3.3. The membership settings and notations are those used before in figure 3.2 .

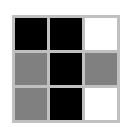

a. Map A

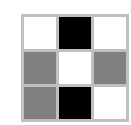

b. Map B

\begin{tabular}{lll}
\hline & Central cell A & Central cell B \\
\hline Crisp vector & $(1,0,0)$ & $(0,1,0)$ \\
Fuzzy Nbh Vector & $(1,0.2,0.5)$ & $(0.5,1,0.5)$ \\
\hline
\end{tabular}

c. Central cell vectors

Figure 3.3 Two neighbourhoods and their central cells

$$
\mathrm{S}\left(\mathrm{V}_{\mathrm{Nbh}, \mathrm{A}}, \mathrm{V}_{\mathrm{Nbh}, \mathrm{B}}\right)=\max \left|\begin{array}{l}
\min (1.0,0.5) \\
\min (0.2,1.0) \\
\min (0.5,0.5)
\end{array}\right|=0.5
$$

The value for similarity ranges from 0 to $1 . S\left(V_{A}, V_{B}\right)$ will equal 0 for two completely dissimilar neighbourhoods and 1 for neighbourhoods with matching 
central cells. The value of 0.5 resulting from the operation is to be interpreted as 'considerably similar'. It is noted, however, that this similarity value is due to the fact that both central cells neighbour a grey cell. And thus the calculated similarity is based on the neighbours rather than the central cells themselves. This is not the intention of the comparison as the following example will illustrate; consider two maps, both maps are forest, except for one cell. This one cell contains a hotel in one map and a waste dump in the other map. The comparison method should acknowledge that hotels and waste dumps are fully distinct and not consider the cell similar only because both the waste dump and the hotel are surrounded by forest. The following section applies the similarity operator $\mathrm{S}\left(\mathrm{V}_{\mathrm{A}}, \mathrm{V}_{\mathrm{B}}\right)$ bi-directionally to resolve this shortcoming.

\subsubsection{Two-way comparison}

By directly comparing the fuzzy representations of two cells a part of the comparison result depends on the comparison of the two neighbourhoods, excluding the central cell. The consequence is that even if two cells at the same location in two maps belong to different categories and these two categories are not similar to any of the categories in the neighbourhood, there is a possibility that the cells are considered similar because their neighbourhoods are similar. This is not intended for the map comparison.

To avoid an overpowering influence of the similarities between the neighbourhoods, the so-called two-way comparison is introduced. It proceeds as follows: in first instance the Fuzzy Neighbourhood Vector of cell A is compared to the Crisp Vector of cell B. Next the Crisp Vector of cell A is compared to the Fuzzy Neighbourhood Vector of cell B. Finally, the lower of the two comparison results establishes the similarity at that location (Equation 3.5).

$$
\mathrm{S}_{\text {TwoWay }}(\mathrm{A}, \mathrm{B})=\left|\mathrm{S}\left(\mathrm{V}_{\text {Nbh }, \mathrm{A}}, \mathrm{V}_{\text {Crisp }, \mathrm{B}}\right), \mathrm{S}\left(\mathrm{V}_{\text {Crisp }, \mathrm{A}}, \mathrm{V}_{\text {Nbh }, \mathrm{B}}\right)\right|_{\text {Min }}
$$

Equation 3.5

The calculation of the two-way similarity value of the central cells in figure 3.3 is calculated according to Equation 3.6 to Equation 3.8. A lower similarity of 0.2 is found.

$$
\mathrm{S}\left(\mathrm{V}_{\mathrm{Nbh}, \mathrm{A}}, \mathrm{V}_{\text {Crisp }, \mathrm{B}}\right)=\max \left|\begin{array}{l}
\min (0.5,1.0) \\
\min (1.0,0.0) \\
\min (0.5,0.0)
\end{array}\right|=0.5
$$




$$
\begin{aligned}
& \mathrm{S}\left(\mathrm{V}_{\text {crisp }, \mathrm{A}}, \mathrm{V}_{\text {nbh }, \mathrm{B}}\right)=\max \left|\begin{array}{l}
\min (1.0,0.0) \\
\min (0.2,1.0) \\
\min (0.5,0.0)
\end{array}\right|=0.2 \\
& \mathrm{~S}_{\text {TwoWay }}(\mathrm{A}, \mathrm{B})=\min (0.5,0.2)=0.2
\end{aligned}
$$

Equation 3.8

Figure 3.4 shows six situations to illustrate the preference for the two-way comparison over the direct comparison of Fuzzy Neighbourhood Vectors. For each situation both the similarity according to the direct comparison of the Fuzzy Neighbourhood Vectors and the two-way comparison are given. It demonstrates that only the two-way comparison yields the intended similarity results.

\subsubsection{Fuzzy Kappa statistic for overall map similarity}

The previous section details how for each cell a local measure of similarity can be calculated. In addition to this, a metric of overall map similarity derived. Such a metric can be derived by integrating all values over the similarity map. Division by the total area then yields a value between 0 (for total disagreement) and 1 (for identical maps). Since regular grid maps are considered, this is equivalent to calculating the mean similarity over all cells.

Mean similarity, however, is not necessarily a good metric of overall similarity, because its expected value would be strongly influence by the number of categories on the map and also on the numerical distribution of cells over those categories. In order to make the results of maps with different numerical distributions better comparable, a statistic is introduced that corrects the mean similarity for the random expected similarity, given the total area of each category on the map.

The statistic is similar to the Kappa statistic and is therefore called Fuzzy Kappa ${ }^{1}$. The formula for Fuzzy Kappa (Equation 3.9) is identical in form to that of the Kappa statistic discussed in chapter 2. The difference is in the calculation of the expected similarity.

\footnotetext{
${ }^{1}$ In the original paper this metric is called Kfuzzy
} 


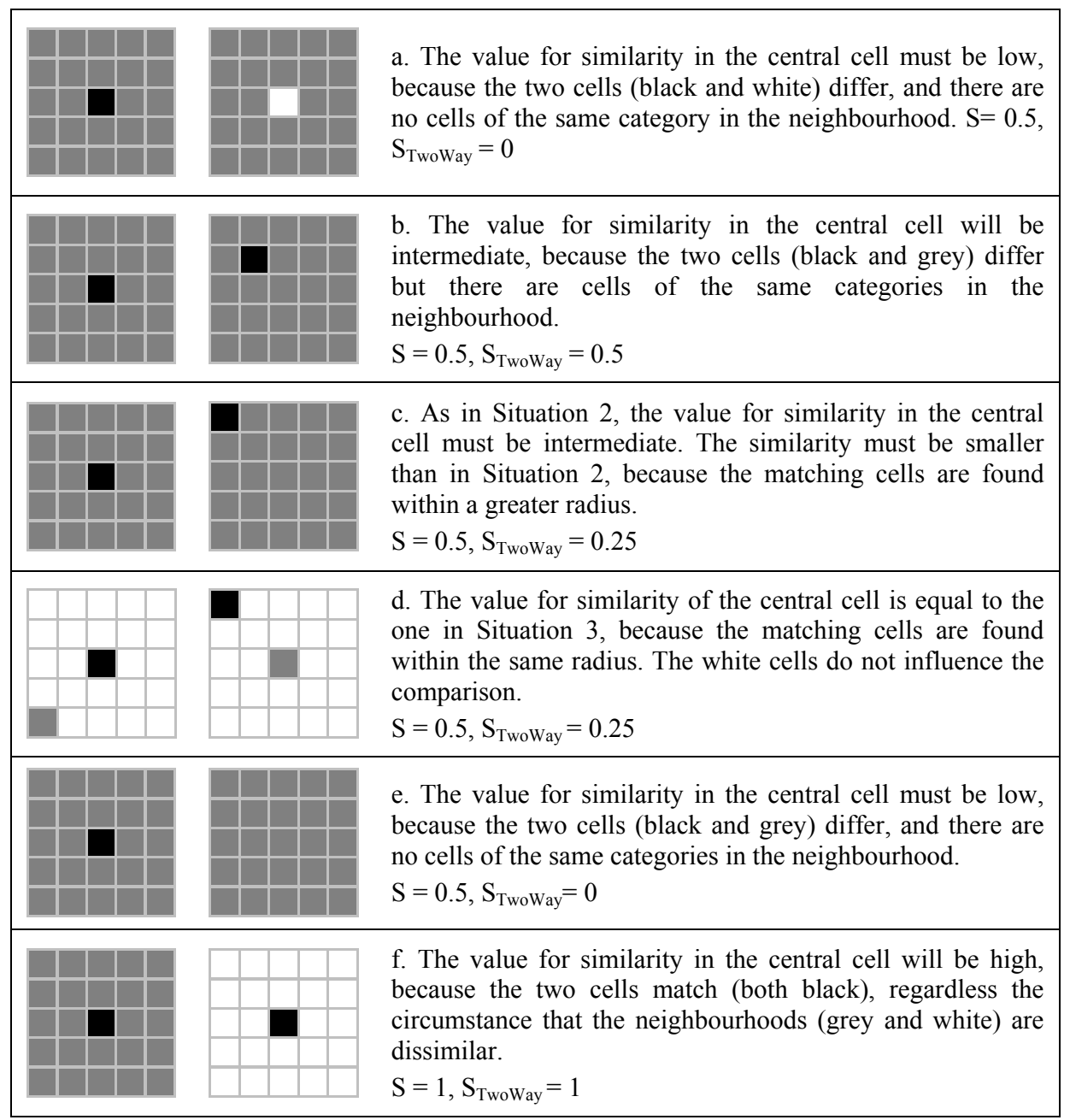

Figure 3.4 Six situations in which the middle cells of the left and right map are compared, with consideration of fuzziness of location. Weights according exponential decay function with halving distance of $\sqrt{ } 2$

FuzzyKappa $=\frac{P(A)-P(E)}{1-P(E)}$

Equation 3.9

where:

$\mathrm{P}(\mathrm{A}) \quad$ observed percentage of agreement (i.e. mean similarity).

$\mathrm{P}(\mathrm{E}) \quad$ expected similarity, based upon given histograms

The following section gives the full mathematical derivation of Fuzzy Kappa. 


\subsection{Derivation of the Fuzzy Kappa statistic}

In a (crisp) categorical map each cell belongs to one category. In the fuzzy set map comparison, an interpretation of the map is made, indicating in the form of a vector how similar the cell is to each of the categories found on the other map. This vector is now called the interpretation vector. Thus, if we consider similarity to be a degree of belonging, the interpretation vector is a fuzzy set (Zadeh 1965). A cell can belong to multiple categories at the same time and the sum of all degrees of belonging may be larger than 1

The interpretation vector is based on two ideas, fuzziness of location and fuzziness of category. By fuzziness of location is meant that a cell is principally defined by the category found there, but to a lesser extent it is also defined by the categories found in its neighbourhood. This means that a cell is similar to the categories found in its proximity. By fuzziness of categories is meant that the distinction between some categories is not sharp and hence some categories are more akin to each other than others. Here the concept of fuzziness is stretched to mean similarity even though that is something else. For instance, the categories 'broad leaved forest' and 'pine forest' are sharply distinct, but for in some contexts they can be considered similar. since they are both forests.

As the interpretation vector is a fuzzy set, fuzzy set theory becomes available and we could use fuzzy similarity measures to express the agreement between the cells at one location in a pair of maps. For instance, a typical min-max similarity measure could be applied on the two interpretation vectors. This approach is not followed however, because it would introduce an unnecessary indirection, as by their definition the interpretation vectors already express similarity directly. (In case of unequal legends it would also be incorrect because the elements in the vectors refer to different categories.) Thus, by direct use of the interpretation vectors, two indications for local similarity are found; 1) the element of the interpretation vector of the location in the first map that refers to the category found in the second map and 2) its reverse counterpart: the element of the interpretation vector of the location in the second map that refers to the category found in the first map. These two indications of local similarity are combined into a single similarity value. For this, the fuzzy logic AND operation is used. Practically, this means that the local similarity is the lesser of the two indications of local similarity.

Besides similarity per cell, also an overall statistic of agreement is calculated. This statistic is called the Fuzzy Kappa, as its definition is analogous to the Kappa statistic. It gives the average similarity corrected for similarity to be expected given the total area taken in by each category and is based on probability and not fuzzy set theory. The motivation to discount for the expected similarity is to prevent the overall similarity statistic from bias towards maps with uneven frequency distributions. Another bias, which is not corrected for, is towards maps with fragmented landscapes. As maps are more 
fragmented, neighbourhoods become more diverse and thus it becomes more likely to find a 'mitigating' category in the neighbourhood. This has the consequence that Fuzzy Kappa values for pairs of maps that are highly clustered may be lower than intuitively expected, as reported by Wealands et al. (2004)

The calculation of average and expected similarity is given in the following two sections. Subsequently the calculation of the Fuzzy Kappa is detailed.

\subsubsection{Calculation of the overall similarity}

The raster maps to be compared are not necessarily rectangular and may also contain gaps. Moreover, the two maps that are to be compared $\left(\mathrm{map}^{A}\right.$ and $\mathrm{map}^{B}$ ) do not need to cover the exact same area. Only for the area they both cover are similarity values calculated. The non-overlapping parts of the maps do play a role in the comparison, because these parts influence the neighbourhood configuration of cells that are being compared as well as the frequency distribution of categories over the maps.

Thus, we have two sets of locations (for $m a p^{A}$ and $\operatorname{map}^{B}$ ) lying on a regular grid as expressed below:

$$
\begin{aligned}
& \operatorname{locs}^{A}=\left\{\mathrm{v}_{1}^{\mathrm{A}}, \mathrm{v}_{2}^{\mathrm{A}}, \cdots, \mathrm{v}_{\mathrm{na}}^{\mathrm{A}}\right\} \\
& \operatorname{locs}^{\mathrm{B}}=\left\{\mathrm{v}_{1}^{\mathrm{B}}, \mathrm{v}_{2}^{\mathrm{B}}, \cdots, \mathrm{v}_{\mathrm{nb}}^{\mathrm{B}}\right\} \\
& \operatorname{locs}=\operatorname{locs}^{\mathrm{A}} \cap \operatorname{locs}^{\mathrm{B}}=\left\{\mathrm{v}_{1}, \mathrm{v}_{2}, \cdots \mathrm{v}_{\mathrm{n}}\right\}
\end{aligned}
$$

where:

$\mathrm{v}_{\mathrm{i}}^{\mathrm{M}} \quad \mathrm{i}$-th cell in map $\mathrm{M}$ cell specified by a row and column number $\left(v_{i}\right.$ $\in \mathbb{N}^{2}$ )

na,nb,n the number of cells in respectively map A, map B and the intersection of the two

The locations are sorted to the effect that the first $n$ elements of $\operatorname{locs}^{A}$ and $\operatorname{locs}^{B}$ coincide. The third set of locations, locs, is the intersection of the former two. A local similarity will be calculated for all cells present in locs.

Every cell on map A and B is occupied by one of the categories present in their respective legends. Let $C^{A}$ and $C^{B}$ be the sets of categories present in the legends of $\operatorname{map}^{A}$ or $\operatorname{map}^{B}$. For the sake of notational simplicity the cell categories are considered identical to their index number in $C^{A}$ and $C^{B}$.

$$
\begin{aligned}
& C^{A}=\{1,2, \ldots, r, r \\
& C^{B}=\{1,2, \ldots, s\}
\end{aligned}
$$

Equation 3.11 


\section{Chapter 3}

where:

$r$ and $s$ the number of categories present in the legends of $\operatorname{map}^{A}$ and $m a p^{B}$.

The functions $m^{A}$ and $m^{B}$ (Equation 3.12) read the category found respectively in $m a p^{A}$ and $m a p^{B}$ given a location. Thus, $m_{l}^{A}$ is the category found at location $l$ in $\operatorname{map}^{A}$ :

$$
\begin{aligned}
& \mathrm{m}^{\mathrm{A}}: \operatorname{locs}^{\mathrm{A}} \rightarrow \mathrm{C}^{\mathrm{A}} \\
& \mathrm{m}^{\mathrm{B}}: \operatorname{locs}^{\mathrm{B}} \rightarrow \mathrm{C}^{\mathrm{B}}
\end{aligned}
$$

The comparison of the two maps at a cell is based upon the configuration of the neighbourhood of that cell in both maps. The neighbourhood of a cell consists of all cells within a certain distance from that cell, including the cell itself. The defining radius is constant over the maps, but not necessarily the same for both maps. The neighbourhood configuration of a cell consists of two vectors: Vector $N$ contains all the categories found in the neighbourhood. Vector $D$ contains the corresponding distances to the central cell of the neighbourhood. The relations are expressed in equations Equation 3.13 and Equation 3.14 below:

$$
\begin{aligned}
& \mathrm{N}_{1}^{\mathrm{A}}=\left\{\mathrm{n}_{1,1}^{\mathrm{A}}, \mathrm{n}_{1,2}^{\mathrm{A}}, \cdots, \mathrm{n}_{1, \mathrm{t}_{1}}^{\mathrm{A}}\right\} \\
& \mathrm{N}_{1}^{\mathrm{B}}=\left\{\mathrm{n}_{1,1}^{\mathrm{B}}, \mathrm{n}_{1,2}^{\mathrm{B}}, \cdots, \mathrm{n}_{1, \mathrm{u}_{1}}^{\mathrm{B}}\right\} \\
& \mathrm{D}_{1}^{\mathrm{A}}=\left\{\mathrm{d}_{1,1}^{\mathrm{A}}, \mathrm{d}_{1,2}^{\mathrm{A}}, \cdots, \mathrm{d}_{1, \mathrm{t}_{1}}^{\mathrm{A}}\right\} \\
& \mathrm{D}_{1}^{\mathrm{B}}=\left\{\mathrm{d}_{1,1}^{\mathrm{B}}, \mathrm{d}_{1,2}^{\mathrm{B}}, \cdots, \mathrm{d}_{1, \mathrm{u}_{1}}^{\mathrm{B}}\right\}
\end{aligned}
$$

Equation 3.14

where:

$u_{l}, t_{l} \quad$ the size of the neighbourhood for map A and B at location $l$.

The size of the neighbourhood differs from location to location due to the edges of the map. The first cell in the neighbourhood is by definition the central cell, thus $d_{l, 1}^{A}=d_{l, 1}^{B}=0, n_{l, 1}^{A}=m_{l}^{A}$ and $n_{l, 1}^{B}=m^{B}{ }_{l}$.

The influence of neighbouring locations diminishes with distance according to a function $F$ (Equation 3.15). This function is not necessarily the same for both maps, but always returns the value 1 for the central cell and returns a value between 0 and 1 for all other neighbouring cells, as follows: 


$$
\begin{aligned}
& \mathrm{F}^{\mathrm{A}}: \mathbb{R}^{+} \rightarrow[0,1] \subset \mathbb{R} \\
& \mathrm{F}^{\mathrm{B}}: \mathbb{R}^{+} \rightarrow[0,1] \subset \mathbb{R} \\
& \mathrm{F}^{\mathrm{A}}(0)=\mathrm{F}^{\mathrm{B}}(0)=1
\end{aligned}
$$

The comparison method also takes into account that some categories found in the legends of $m a p^{A}$ and $m a p^{B}$ are more similar to each other than others. This is expressed by an index of similarity between 0 and 1 for each combination of categories. Categorical similarity is thus expressed as matrix $M$ in Equation 3.16:

$$
\mathrm{M}=\left(\begin{array}{ccc}
\mathrm{M}_{1,1} & \cdots & \mathrm{M}_{1, \mathrm{~s}} \\
\vdots & \ddots & \vdots \\
\mathrm{M}_{\mathrm{r}, 1} & \cdots & \mathrm{M}_{\mathrm{r}, \mathrm{s}}
\end{array}\right)
$$

where:

$\mathrm{M}_{\mathrm{ij}} \quad$ The similarity of category $\mathrm{i}$ in the legend of $\operatorname{map}^{A}$ and category $\mathrm{j}$ in the legend of $\operatorname{map}^{B} .\left(M_{i, j} \in[0,1] \subset \mathbb{R}\right)$

Categorical similarities are assumed to be mutual relations, the similarity of category $a$ to $b$ is identical to the similarity $b$ to $a$.

For every location two interpretation vectors are calculated, $S_{l}^{A}$ and $S_{l}^{B}$. These vectors express for both maps how similar that location is to all categories found in the other map. For one category, this equals the maximum contribution to the similarity over all locations in the neighbourhood, taking into account both the categorical similarity and the distance decay function. Equation 3.17 formalizes this relation:

$$
\begin{aligned}
& \mathrm{S}_{1}^{\mathrm{A}}=\left\{\operatorname{sim}_{1,1}^{\mathrm{A}} \operatorname{sim}_{1,2}^{\mathrm{A}}, \cdots, \operatorname{sim}_{1, \mathrm{~s}}^{\mathrm{A}}\right\} \\
& \mathrm{S}_{1}^{\mathrm{B}}=\left\{\operatorname{sim}_{1,1}^{\mathrm{B}} \operatorname{sim}_{1,2}^{\mathrm{B}}, \cdots, \operatorname{sim}_{1, \mathrm{r}}^{\mathrm{B}}\right\} \\
& \operatorname{sim}_{1, \mathrm{~b}}^{\mathrm{A}}=\max _{\mathrm{j}=1}^{\mathrm{t}_{1}}\left(\mathrm{M}_{\mathrm{n}_{1, \mathrm{j}}^{\mathrm{A}} \mathrm{b}} * \mathrm{~F}^{\mathrm{A}}\left(\mathrm{d}_{1, \mathrm{j}}^{\mathrm{A}}\right)\right) \\
& \operatorname{sim}_{1, \mathrm{a}}^{\mathrm{B}}=\max _{\mathrm{k}=1}^{\mathrm{u}_{1}}\left(\mathrm{M}_{\mathrm{a}, \mathrm{n}_{1, \mathrm{k}}^{\mathrm{B}}} * \mathrm{~F}^{\mathrm{B}}\left(\mathrm{d}_{1, \mathrm{k}}^{\mathrm{B}}\right)\right)
\end{aligned}
$$

where:

$a, b \quad$ indices to $\mathrm{C}^{A}$ respectively $C^{B}$. 
Equation 3.18 calculates the overall similarity of the cell, $S_{l}$, by taking the minimum similarity of $\mathrm{map}^{A}$ to the category found in $\mathrm{map}^{B}$ at that location and vice versa:

$$
\mathrm{S}_{1}=\min \left(\operatorname{sim}_{1, \mathrm{~m}_{1}^{\mathrm{B}}}^{\mathrm{A}}, \operatorname{sim}_{1, \mathrm{~m}_{1}^{\mathrm{A}}}^{\mathrm{B}}\right)
$$

The map similarity is calculated as the average similarity over all cells, as in Equation 3.19:

$$
\mathrm{S}=\frac{\sum_{\mathrm{l}=1}^{\mathrm{n}} \mathrm{S}_{1}}{\mathrm{n}}
$$

Equation 3.19

\subsubsection{Calculation of the expected overall similarity}

Equation 3.20 defines the probability of a cell on $\operatorname{map}^{A}$ to be taken in by category $a$ according to the frequency of occurrence of $a$ on A:

$$
\mathrm{p}_{\mathrm{a}}^{\mathrm{A}} \equiv \frac{\sum_{\mathrm{l}=1}^{\mathrm{n}^{\mathrm{A}} \delta_{\mathrm{m}_{1}^{\mathrm{A}}, \mathrm{a}}}}{\mathrm{n}^{\mathrm{A}}}
$$

where:

$\delta_{x, y} \quad$ is the Kronecker delta, returning 1 when $x=y$ and 0 otherwise.

The $p^{B}{ }_{b}$ 's are defined analogously.

Based on this definition of the probabilities regarding the category occupying a cell in map $^{\mathrm{A}}$ and $\mathrm{map}^{\mathrm{B}}$, we can now calculate the expected value of $\mathrm{S}$ for the comparison area.

The local similarity, as expressed in Equation 3.18 , only depends upon the neighbourhood configuration found in $\mathrm{map}^{A}$ and $\mathrm{map}^{B}$. Considering that the distance vectors $D_{l}$ are fixed, the similarity only depends on the categories found at the different offsets in the neighbourhood. This means that, as the number of neighbourhood configurations is limited, the number of possible local similarity values is too. The vector $Z_{i}$ contains all possible neighbourhood occupancies for cell $l$ (Equation 3.21). The number of possible combinations $(z)$ follows from the number of cells in the neighbourhoods $\left(t_{l}\right.$ and $\left.u_{l}\right)$ and the number of categories present in the maps ( $r$ and $s$ ) as below:

$$
\mathrm{z}=\mathrm{r}^{\mathrm{t}_{1}} * \mathrm{~s}^{\mathrm{u}_{1}}
$$


The vectors $P_{i}$ (Equation 3.22) and $X_{i}$ (Equation 3.23) give respectively the probability and local similarity value that correspond to each neighbourhood configuration.

$$
\begin{aligned}
& \mathrm{P}_{1}=\left(\mathrm{p}_{1,1}, \mathrm{p}_{1,2}, \cdots, \mathrm{p}_{\mathrm{l}, \mathrm{z}}\right) \\
& \mathrm{p}_{\mathrm{l}, \mathrm{i}}=\prod_{\mathrm{j}=1}^{\mathrm{t}} \mathrm{p}_{\mathrm{n}_{\mathrm{l}, \mathrm{i}, \mathrm{j}}^{\mathrm{A}}}^{\mathrm{A}} * \prod_{\mathrm{k}=1}^{\mathrm{u}} \mathrm{p}_{\mathrm{n}_{\mathrm{l}, \mathrm{i}, \mathrm{k}}^{\mathrm{B}}}^{\mathrm{B}} \\
& \mathrm{X}_{1}=\left(\mathrm{x}_{1,1}, \mathrm{x}_{1,2}, \cdots, \mathrm{x}_{1, \mathrm{z}}\right)
\end{aligned}
$$

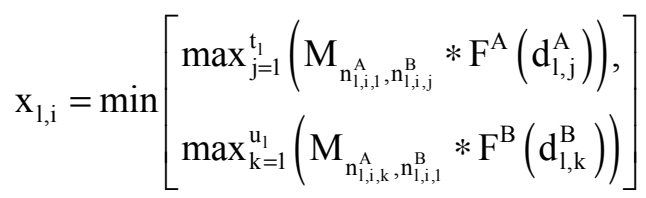

Equation 3.23

In other words, $P_{i}$ is the probability distribution of the outcome of the similarity values which are in the vector $X_{i}$, and thus the expected local similarity can be calculated as the sum product of probability and similarity (see Equation 3.24).

$$
\mathrm{E}\left(\mathrm{S}_{1}\right)=\sum_{\mathrm{i}=1}^{\mathrm{z}}\left(\mathrm{p}_{1, \mathrm{i}} * \mathrm{x}_{1, \mathrm{i}}\right)
$$

Equation 3.25 calculates the expected similarity as the average expected similarity over all cells.

$$
\mathrm{E}=\mathrm{E}(\mathrm{S})=\frac{\sum_{\mathrm{l}=1}^{\mathrm{n}} \mathrm{E}\left(\mathrm{S}_{1}\right)}{\mathrm{n}}
$$

The number $z$ can be quite large and for many practical purposes the straightforward implementation of the equations presented here will not be possible. Substantial efficiency gains in the computation can be made by taking advantage of the fact that there are large groups of neighbourhood configurations that lead to identical similarity values.

\subsubsection{Calculation of the Fuzzy Kappa}

The Fuzzy Kappa is calculated in the same manner as the (crisp) Kappa:

$$
\text { Fuzzy Kappa }=\frac{S-E}{1-E}
$$


The calculation detailed in this chapter can be time consuming. An approximation can be made by assuming that all offsets found in the neighbourhood are present on the map for all locations. In that case the expected value of similarity is constant over the map and thus only needs to be calculated once. In practice this means that for equations 13 to 16 the subscript $l$ is cancelled and that $t=t^{\max }$ and $u=u^{\max }$.

\subsection{Results}

\subsubsection{Case A: Synthetic dataset}

The two maps in figure 3.5 were created in order to demonstrate the features of the map comparison method. Several types of differences occur: minor shifts, major shifts, growth/decline, introduction/removal, and differences of cell categories within clusters of similar content. The method is symmetrical; this means that there is no difference between comparing map 1 with map 2 or vice versa. Therefore, growth is equivalent to decline, as is introduction to removal.

Figure 3.6 gives the results of the direct cell-by-cell method (a) and the proposed fuzzy cell-by-cell method (b). The fuzzy membership function is that of exponential decay with a halving distance of two cells and a neighbourhood with a four-cell radius. The direct cell-by-cell method consists of the pair-wise comparison of the categories in each cell of the two maps; Cells where the maps are identical in both maps are in white, cells where the categories differ are in black. In the fuzzy comparison map lighter cells are more similar than darker cells.

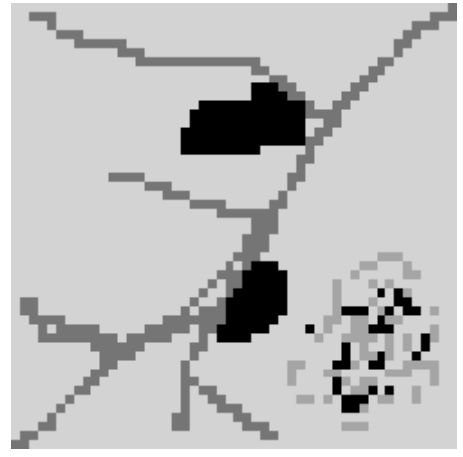

a. Map 1

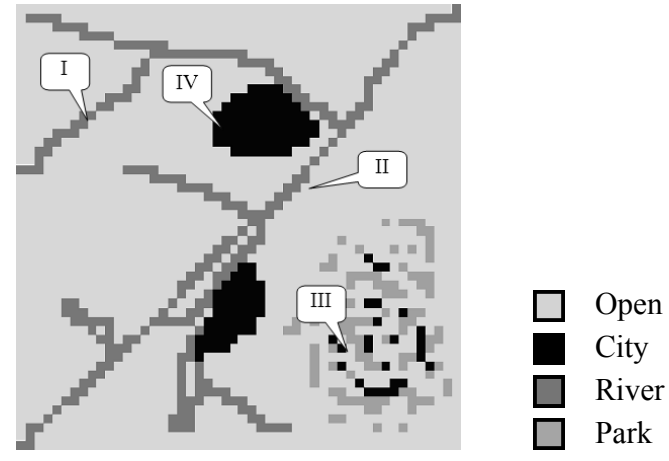

b. Map 2

I. Introduction of new landscape element

II. Most of river; minor shifts

III. Many differences at the cell level, but similar clusters at the macro level IV. Major decrease and shift of city

Figure 3.5 The two maps to compare. Different types of differences are marked on the second map. 


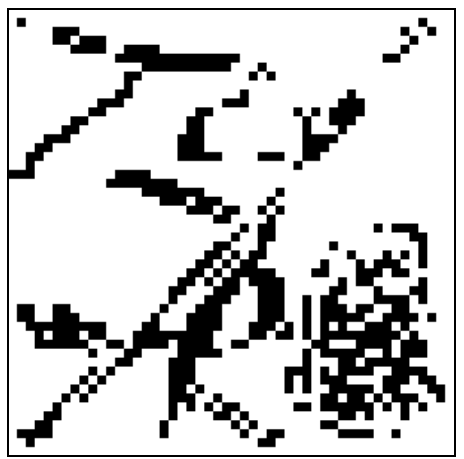

a. Cell-by-cell comparison

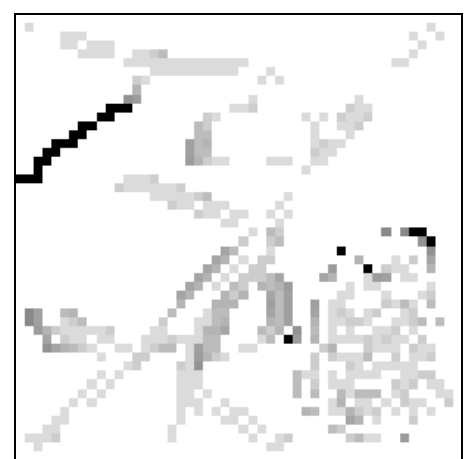

b. Fuzzy comparison of maps

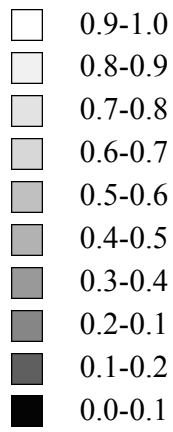

$0.9-1.0$

$0.6-0.7$

$0.5-0.6$

.3-0.4

. $1-0.2$

$0.0-0.1$

Figure 3.6 Comparison results

The comparison map that results from the procedure contains values between 0 and 1. This can be more detail than required. Based on the objective of the map comparison it can be worthwhile to include a classifying step. For instance it is possible to distinguish between total agreement, medium similarity and low similarity. Figure 3.7 gives the map resulting from classification with the use of a threshold level at 0.65 . The areas containing new introductions (e.g. the added linear element in the upper left corner) or major shifts (e.g. the shifts of two larger oval shapes) are distinguished from the areas of minor shifts (e.g. the other linear elements) and fluctuations within patterns (e.g. the pattern of coloured cells at the lower right side of the map).

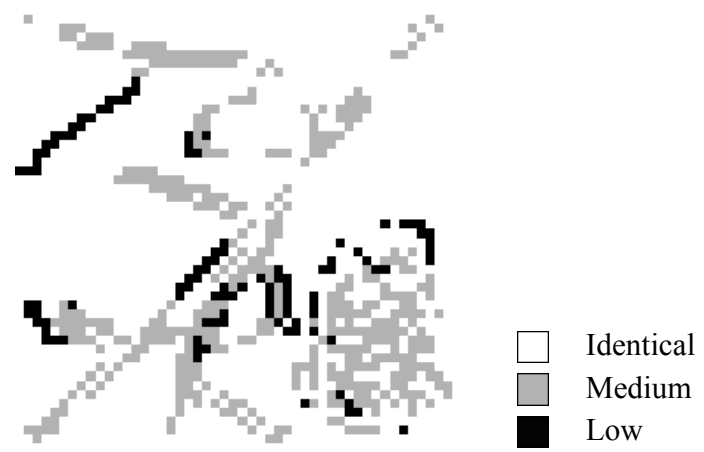

Figure 3.7 Three levels of agreement by the proposed fuzzy comparison method

Fuzzy Kappa is calculated to be 0.49 . This means that the maps are significantly more similar than would be expected solely from the number of cells of each category, because that level of similarity has the Fuzzy Kappa value of 0 . The maps are, however, also clearly distinct, because highly similar maps will have a Fuzzy Kappa value close to 1, which stands for completely identical. As a bare figure the Fuzzy Kappa statistic is not highly informative. It is more informative if there is reference material available as in the practical case presented in the next section 


\section{Chapter 3}

\subsubsection{Case B: The Dublin model}

The case presented here applies the two-way fuzzy comparison method for validation. It compares results generated by a model with real data. The particular model is a constrained Cellular Automaton as described in Chapter 1 (White et al. 1997). The model is applied for the study of the urban development of Dublin, as part of the MURBANDY and MOLAND projects of the European Union's Joint Research Centre (White et al. 2000).

Three maps are compared with the observed 1998 data (figure 3.8). In the first instance the 1988 base map (Figure 3.9 a), which was the starting situation for the model is. Next the 1998 map generated by the original model (figure $3.9 \mathrm{~b}$ ). Finally, the 1998 map generated by an improved version of the model. (figure $3.9 \mathrm{c})$. The land-use maps are found in the left column, the comparison maps in the right. Lighter cells in the comparison maps indicate larger similarity.
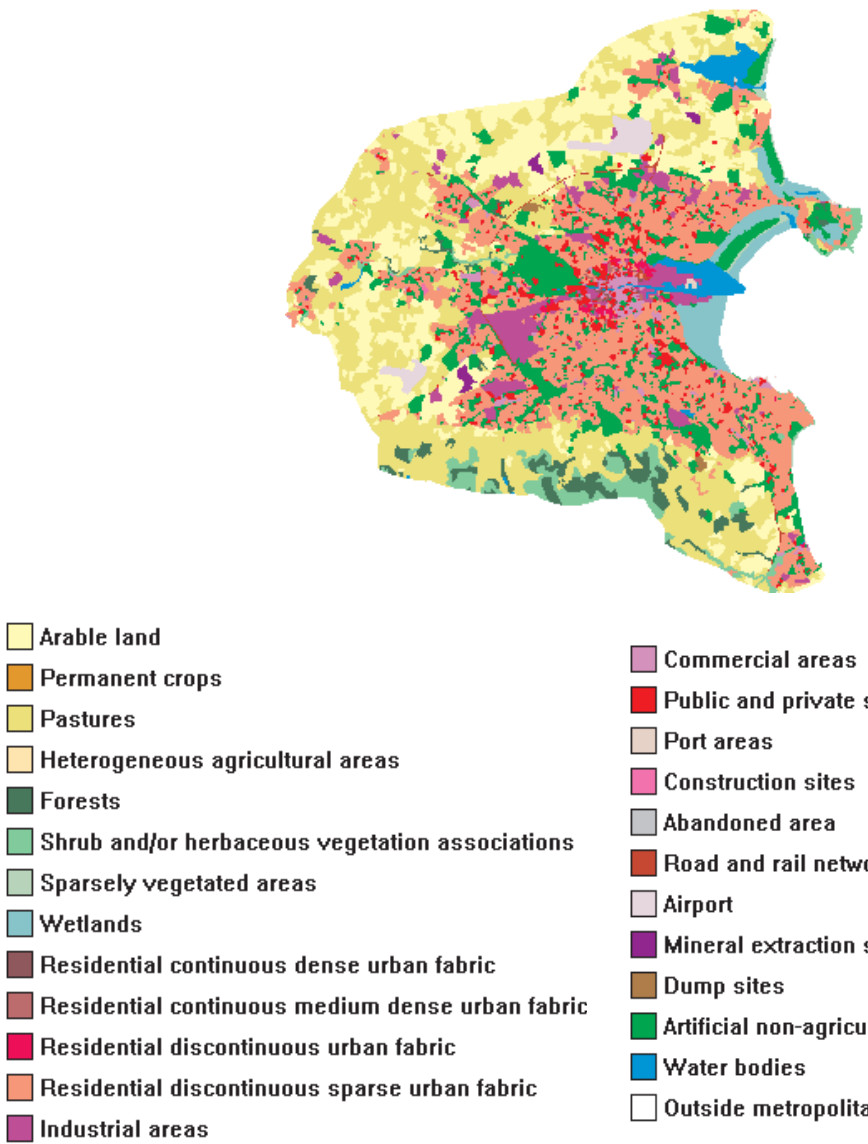

$\square$ Commercial areas
$\square$ Public and private services
$\square$ Port areas
$\square$ Construction sites
$\square$ Abandoned area
$\square$ Road and rail networks and associated land
$\square$ Airport
$\square$ Mineral extraction sites
$\square$ Dump sites
$\square$ Artificial non-agricultural vegetated areas
$\square$ Water bodies
$\square$ Outside metropolitan area

Figure 3.8 Dublin 1998 validation data 
The comparison with the base data (figure 3.9 a) yields a relatively high Fuzzy Kappa (0.90), even though the modelling effort is nihil. Interpretation of the comparison map learns that between 1988 and 1998 a small number of cells change land-use, however the changes are severe (not many cells are coloured grey; these are however mostly dark grey). The Fuzzy Kappa of the base map can be used as a reference level. Models scoring lower than 0.90 do 'more damage than good', while models scoring higher achieve 'better than minimally required'.

The results from the original model (figure $3.9 \mathrm{~b}$ ) contain a relatively large number of cells that are not identical (they are grey) and their similarity is relatively low (they are mostly dark grey). As a result Fuzzy Kappa is smaller than that of the 1988 base data. Finally, the result map of the improved model still contains a large number of non-identical cells, however the similarity of these cells is relatively high (they are lighter grey). The resulting Fuzzy Kappa is higher than that of the base data and therefore yields a positive validation of this model. 

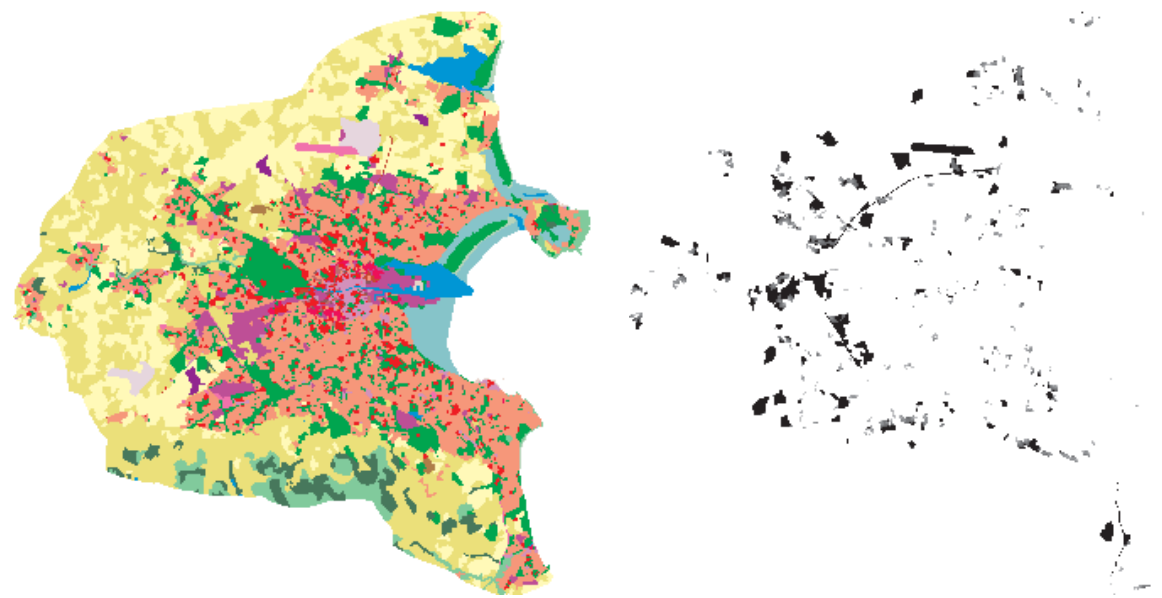

a1. Dublin 1988 base data

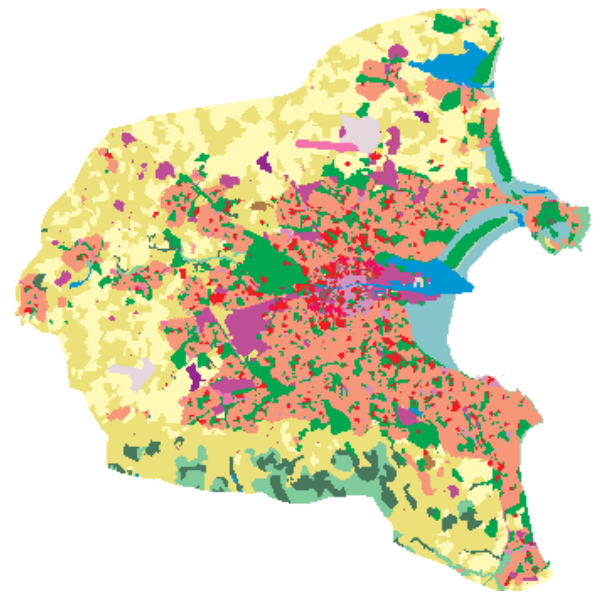

a2. Fuzzy Kappa: 0.90

b1. Dublin 1998 model

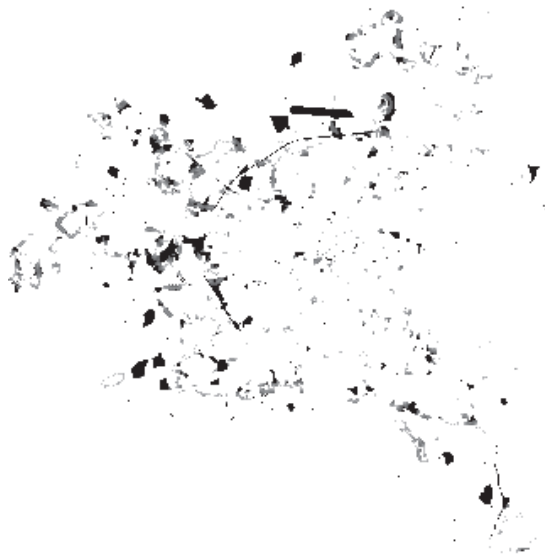

b2. Fuzzy Kappa: 0.89
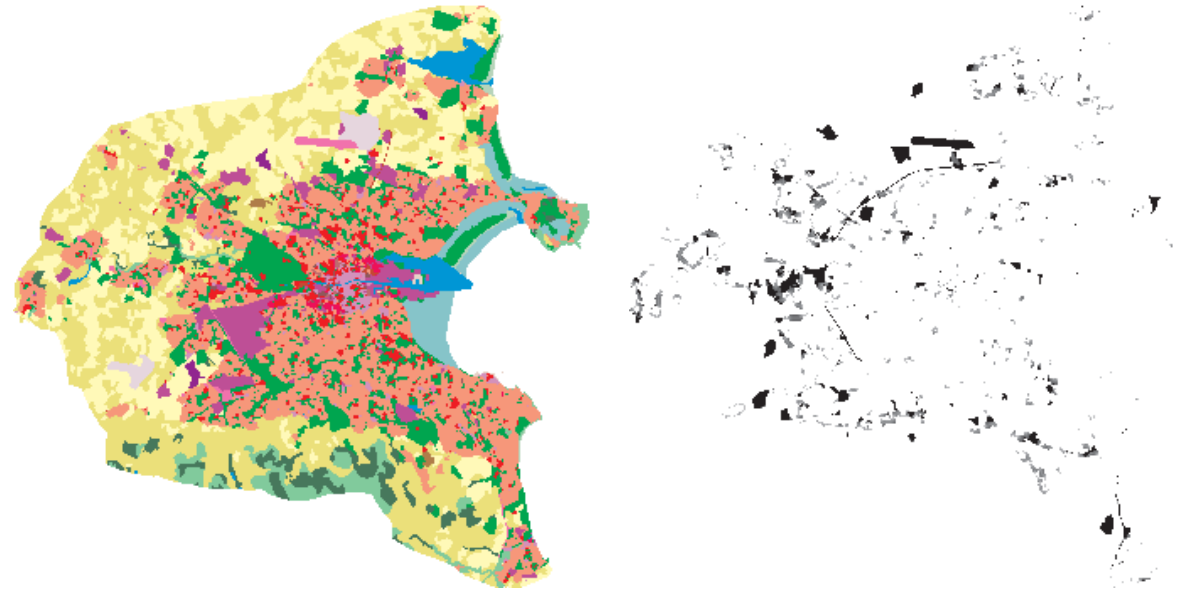

c1. Dublin 1998 improved model

c2. Fuzzy Kappa: 0.91

Figure 3.9 Three comparison results from validation process 


\subsubsection{Case C: Approaching human judgement}

The introduction of this chapter argued that traditional map comparison methods do not distinguish small differences from large differences, leading to comparison results that are not in accordance with human judgment. The fuzzy set map comparison method should produce results that are in better accordance to human judgement.

To validate the assumption that fuzzy set map comparison does approach human judgment closer than the cell-by-cell methods introduced in chapter 2, a test case is considered. The case was available from a map comparison survey held over the Internet (Kuhnert 2002, Kuhnert et al. 2005). Participants of the survey were presented ten pairs of categorical maps and then asked to express the similarity of each pair as a number between 0 and 1 . After 186 participants filled out the form, the average similarity of each pair was calculated. The maps of the survey are small, $32 * 32$ cells, and consist of 5 different colours (yellow, brown, green, dark blue, pale blue). There is no legend provided. The maps can be found in figure 3.10 .

The correlation between similarities as expressed by the participants and as given by the comparison methods is evaluated. The fuzzy set map comparison is performed for several fuzzy settings. In first instance the settings that were also used for the other 2 cases are applied (exponential distance decay with a halving distance of two cells and a maximum radius of four cells). Additionally the Fuzzy Kappa settings are optimized for closest resemblance (correlation) to the survey. The reason to consider correlation and not, for instance, absolute or squared differences is that the theoretical ranges of values for the different methods and the survey answers do not correspond.

The similarity according to Percentage of agreement, Kappa and Fuzzy Kappa are presented in table 3.4. The results indicate that as expected the correlation with survey results is highest for Fuzzy Kappa (0.90). For Kappa (0.88) it is higher than for proportion of agreement (0.84). After tuning the parameters of the fuzzy set map comparison to the results of the Internet survey an even higher correlation is found (0.93). The settings are exponential decay with a halving distance of 1 cell and a maximum radius of 6 cells. Figure 3.11 plots the correspondance between the survey and the comparison results. 

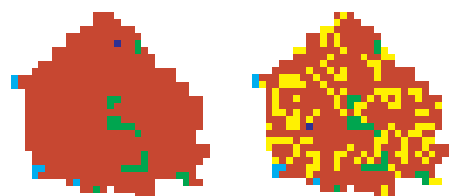

a. Pair 1

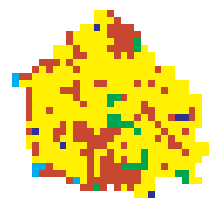

c. Pair 3

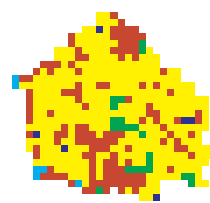

e. Pair 5

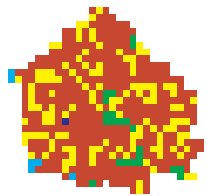

g. Pair 7

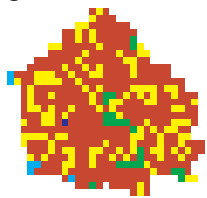

i. Pair 9
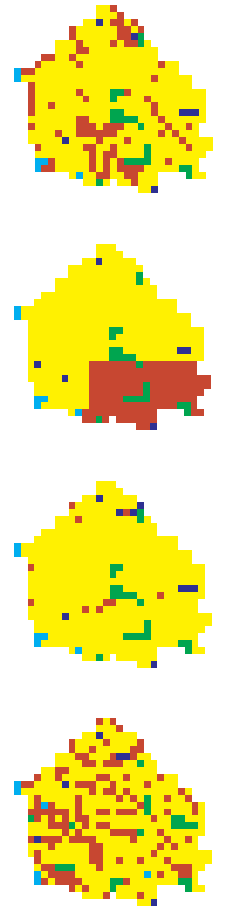

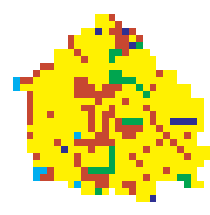

b. Pair 2

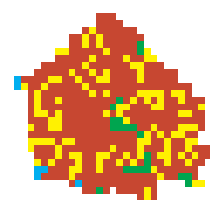

d. Pair 4

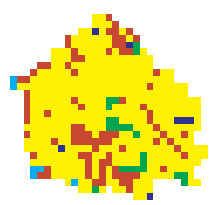

f. Pair 6

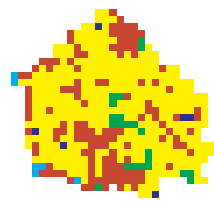

h. Pair 8

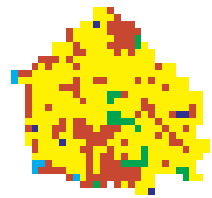

j. Pair 10
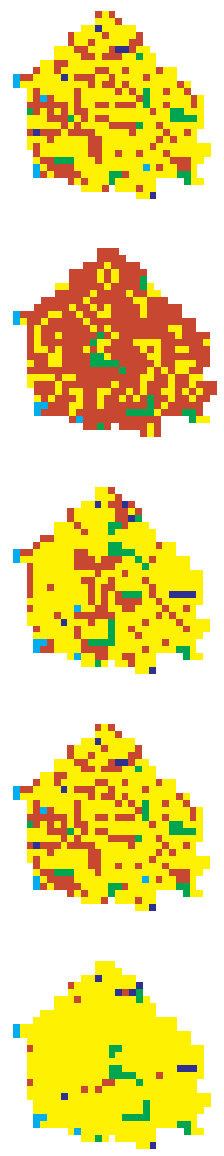

Figure 3.10 Ten pairs of maps found in the web survey.

The survey presented here is limited in scope, offering only 10 maps that due to their small size are not fully representative of maps that are typically compared. Nevertheless the results offer empirical support for the idea that Fuzzy Kappa approaches human judgment closer than the (crisp) Kappa and the percentage of agreement.

The results also contribute to the discussion about the need for 'chance correction' in accuracy assessment (Turk 2002, Stehman 2002). It is found that in this case chance correction does align the agreement statistic with human interpretation. 
Table 3.4 Comparison results, $P$ oA $=$ proportion of agreement, $F K=$ Fuzzy Kappa $^{l}$

\begin{tabular}{llllll}
\hline Pair & Survey & PoA & Kappa & FK(initial) & FK(optimal) \\
\hline 1 & 0.39 & 0.75 & 0.27 & 0.20 & 0.23 \\
2 & 0.40 & 0.61 & 0.15 & 0.14 & 0.15 \\
3 & 0.61 & 0.91 & 0.81 & 0.81 & 0.80 \\
4 & 0.73 & 0.87 & 0.69 & 0.71 & 0.70 \\
5 & 0.28 & 0.68 & 0.33 & -0.26 & 0.04 \\
6 & 0.48 & 0.81 & 0.54 & 0.52 & 0.51 \\
7 & 0.22 & 0.32 & 0.11 & 0.07 & 0.09 \\
8 & 0.36 & 0.62 & 0.20 & 0.14 & 0.16 \\
9 & 0.29 & 0.42 & 0.11 & 0.04 & 0.07 \\
10 & 0.45 & 0.76 & 0.37 & 0.35 & 0.36 \\
Correlation & 1.00 & 0.84 & 0.88 & 0.90 & 0.93 \\
\hline
\end{tabular}

Percentage-of-Agreement

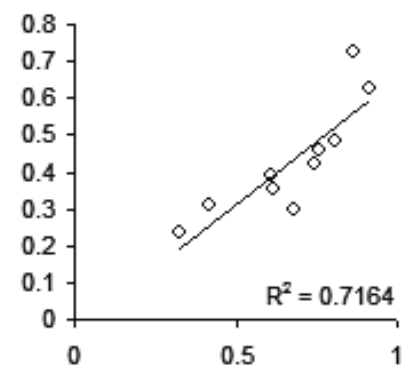

Fuzzy Kappa (initial)

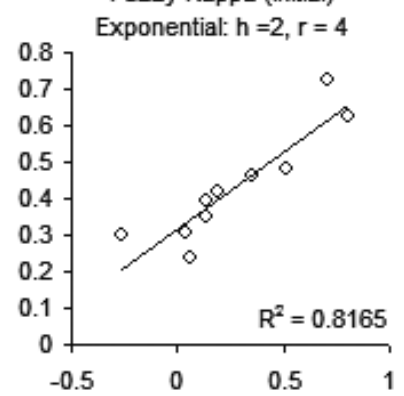

Kappa
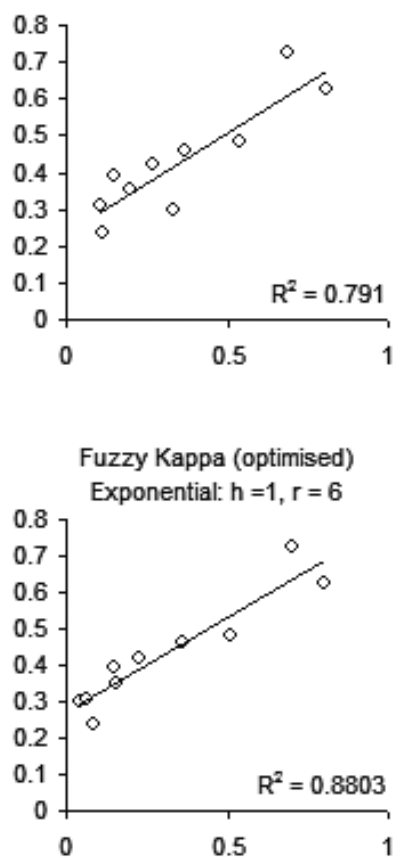

Figure 3.11 Correlation graphs, the automated comparison results are plotted against the similarity expressed in the survey.

${ }^{1}$ The numerical results differ from those presented by Kuhnert et al. (2005). There is a mismatch between the results presented on the survey website and those reported in the paper. The results are based on the survey website (Kuhnert 2002). Replacing the data leads to correlations that are about $10 \%$ smaller, but yield the same ranking of results. 


\subsection{Conclusion}

By applying fuzzy set theory for the comparison of categorical maps it is possible to obtain a spatial and gradual analysis of similarity of two maps. The results from the comparison are basically in accordance with those of a visual inspection: it distinguishes minor deviations and fluctuations within similar areas from major deviations. The third case confirms the idea that the new method comes approximates human judgement better than existing approaches, even though the experiment is too limited to formulate strong conclusions on the nature of human judgement in map comparison. The comparison method considers uncertainty and vagueness in the specification of the location of categories (fuzziness of location) as well as in the definition of the categories (fuzziness of category). The fuzziness of category is largely ignored in this chapter but treated extensively in chapter 4 .

The fuzzy set based comparison is an extension of the crisp methods described in chapter 2 . The fuzzy similarity map extends the binary agreement map. From the fuzzy similarity map it is possible to read which cells are identical and which not, but moreover for the non-identical cells the degree of agreement is given. This means that the fuzzy set map comparison gives the same information as the cell-by-cell comparison, and more.

The mean over the fuzzy similarity map extends the crisp fraction of agreement by also considering near overlap and categorical similarity. Likewise, the Fuzzy Kappa statistic extends the Kappa statistic. Under settings without fuzziness, mean fuzzy similarity is identical to fraction of agreement and Fuzzy Kappa statistic is identical to the Kappa statistic.

The results of remote sensing and high-resolution spatial models can be assessed in more detail than before. Based upon the spatial comparison results it is possible to specify the discrepancies between observed data and model results. Furthermore the comparison map can be used to find correlations between similarity and other spatial occurrences (e.g. certain categories, distances from landmarks, geographical and political boundaries etc.).

The fuzziness of location that is applied holds that the degree of belonging of a cell to a category is determined by the nearest neighbour of that category. This implies that there is no local control on quantities, i.e. the presence of a category in one location can compensate the absence of that category in multiple other locations. Another disadvantage of the fuzzy set map comparison is that is does not explicitly address spatial structure. The method accounts for overlap and near-overlap, but not for similarity in composition and configuration. The moving windows based structure comparisons of chapter 6 address both the control on local quantity and the explicit comparison of spatial structure. 
The fuzzy set map comparison method can be of practical use in the calibration of spatial models. Since the method does rewards near overlap as well as overlap, it is more likely to pick up on small improvements in the parameter settings. The spatially detailed account of map similarity can guide parameter and model improvements to those areas or categories with the severest disagreement.

The applicability of the method is not restricted to geographical problems; other fields of potential use are image analysis, pattern recognition and video image analysis. 



\section{Advanced use of categorical fuzziness}

\subsection{Introduction}

The methods presented in this chapter are an extension to the methods presented in the previous chapter. That chapter introduced a method for comparing categorical maps taking into account both proximity relations and the fact that some pairs of categories are more similar than others. Proximity relations are generally not taken into account in map comparison methods as most methods are based on analysis of the contingency table, which summarizes cell-to-cell agreement and disagreement (Foody 2002). The fuzzy set map comparison belongs to a less prominent, but growing, tradition of considering geographical coherence in the assessment of map similarity. Approaches that do so address the presence and overlap of features (Power et al. 2002, Remmel \& Perera 2002), local composition and configuration (Csillag \& Boots 2004), apply swap heuristics (Ehlschlager 2000, Fewster \& Buckland 2001) or compare maps that are rescaled to different resolutions (Costanza 1989, Pontius 2002). The approach in Chapter 3 is different all together, but most resembles swap and multi-resolution methods, as differences found at a location may be mitigated by categories found in the neighbourhood.

The current chapter has two main parts. First, the use of the categorical similarity matrix is discussed and applications of the matrix are detailed that were not originally intended or documented. The next section demonstrates the advances made, by re-examining the two datasets of the previous chapter as well as a third dataset that consists of two maps with unequal legends.

\subsection{Method}

The previous chapter proposed to use the categorical similarity matrix for the purpose of taking into account that some categories are more similar to each other than others. When, for instance, the categories 'pine forest' and 'broad leafed forest' are more similar to each other than to the categories 'urban' and 'agricultural land', then the matrix of table 4.1 may be applied. A second 


\section{Chapter 4}

example considers categories of an ordinal nature; this example is given in table 4.2.

Table 4.1 An example similarity matrix where pine and broad leaved forest are similar to each other.

\begin{tabular}{lllll}
\hline map A $\downarrow:$ map B $\rightarrow$ & pine... & broad... & urban & Agri... \\
\hline pine forest & 1 & 0.5 & 0 & 0 \\
broad leaved forest & 0.5 & 1 & 0 & 0 \\
Urban & 0 & 0 & 1 & 0 \\
agricultural land & 0 & 0 & 0 & 1 \\
\hline
\end{tabular}

Table 4.2 An example similarity matrix where the residential categories have an ordinal relation

\begin{tabular}{llllll}
\hline map A $\downarrow:$ map B $\rightarrow$ & high.... & medium.... & Low... & agri... & forest \\
\hline high density residential & 1 & 0.4 & 0.2 & 0 & 0 \\
medium density residential & 0.4 & 1 & 0.4 & 0 & 0 \\
low density residential & 0.2 & 0.4 & 1 & 0 & 0 \\
Agriculture & 0 & 0 & 0 & 1 & 0 \\
Forest & 0 & 0 & 0 & 0 & 1 \\
\hline
\end{tabular}

\subsubsection{Setting legend items equal}

One new use of the category matrix is to temporarily set two or more categories equal. Thus the matrix functions as a tool for 'on the fly' reclassification. The similarity matrix of table 4.3 signifies that the difference between 'pine forest' and 'broad leafed forest' are ignored in the comparison.

Another use of the categorical similarity matrix is to assess the similarity of a single category. Following Monserud \& Leemans (1992) all categories except the category being considered are set as being identical to each other. Table 4.4 gives the similarity matrix for this comparison regarding the category 'Urban'. Comparing maps per category can serve different purposes for instance it may be necessary to rank the different categories according to the degree of similarity in order to prioritize further actions. Knowing to what extent differences between maps are related to individual categories may also help to understand the nature of the differences. 
Table 4.3 An example similarity matrix where pine and broad leaved forest are considered equal in the comparison

\begin{tabular}{lllll}
\hline map A $\downarrow:$ map B $\rightarrow$ & pine... & broad... & urban & agri... \\
\hline pine forest & 1 & 1 & 0 & 0 \\
broad leaved forest & 1 & 1 & 0 & 0 \\
Urban & 0 & 0 & 1 & 0 \\
agricultural land & 0 & 0 & 0 & 1 \\
\hline
\end{tabular}

Table 4.4 An example similarity matrix where the category urban is considered separately.

\begin{tabular}{lllll}
\hline map A $\downarrow:$ map B $\rightarrow$ & pine $\ldots$ & broad... & urban & agri... \\
\hline pine forest & 1 & 1 & 0 & 1 \\
broad leaved forest & 1 & 1 & 0 & 1 \\
Urban & 0 & 0 & 1 & 0 \\
agricultural land & 1 & 1 & 0 & 1 \\
\hline
\end{tabular}

\subsubsection{Separating omission and commission}

Applying asymmetrical categorical similarity matrices gives the option to separately consider differences due to omission and commission or appearing and disappearing. The terms omission and commission have a meaning in the context of accuracy assessment, whereas appearing and disappearing relate to comparison of maps for different moments in time. Differences (errors) due to commission of a category are locations where the category is placed where it should not be (false positives) and differences due to omission are those where the category is not found, but where it should be (false negatives). In practical situations the implications of differences due to omission and commission may be quite different. For instance, models dedicated to the early detection of problem areas (e.g. fire, desertification, pollution) may, under the precautionary principle, be used with a high tolerance for errors due to commission and a small tolerance for errors due to omission. When used in a later stage (e.g. once resources are being allocated) this tolerance may be reversed. The similarity matrix given in table 4.5 is used to assess the fuzzy difference resulting from commission of the category urban (in $m a p^{B}$ relative to $m a p^{A}$ ); this is achieved by considering only those cells dissimilar where 'Urban' is found in $\mathrm{map}^{B}$ and not in $\mathrm{map}^{A}$. The transposed matrix (table 4.6) registers differences due to omission instead. 


\section{Chapter 4}

Table 4.5 An example similarity matrix where only commission of the category urban is considered

\begin{tabular}{lllll}
\hline map A $\downarrow:$ map B $\rightarrow$ & pine... & broad... & urban & agri... \\
\hline pine forest & 1 & 1 & 0 & 1 \\
broad leaved forest & 1 & 1 & 0 & 1 \\
urban & 1 & 1 & 1 & 1 \\
agricultural land & 1 & 1 & 0 & 1 \\
\hline
\end{tabular}

Table 4.6 An example similarity matrix where only omission of the category urban is considered

\begin{tabular}{lllll}
\hline map A $\downarrow:$ map B $\rightarrow$ & pine... & broad $\ldots$ & urban & agri... \\
\hline pine forest & 1 & 1 & 1 & 1 \\
broad leaved forest & 1 & 1 & 1 & 1 \\
urban & 0 & 0 & 1 & 0 \\
agricultural land & 1 & 1 & 1 & 1 \\
\hline
\end{tabular}

An asymmetrical categorical similarity matrix can express differences in the weighting of omission and commission. The similarity matrix in Table 4.7 gives such a matrix where omission is weighted stronger than commission. When exploring differences between two maps, such a setting would rarely have merit, because if omission and commission have a distinct meaning it is more worthwhile to consider them in two separate maps than to confound them in a single one. However, when applied in an automated procedure, such as the automatic calibration by Straatman et al. (2004) it is necessary to express similarity in a single statistic and better results may be obtained when different types of error are weighted differently.

Table 4.7 An example similarity matrix where only the category urban is considered and omission weights stronger than commission

\begin{tabular}{lllll}
\hline map A $\downarrow:$ map B $\rightarrow$ & pine... & broad... & urban & agri... \\
\hline pine forest & 1 & 1 & 0.5 & 1 \\
broad leaved forest & 1 & 1 & 0.5 & 1 \\
Urban & 0 & 0 & 1 & 0 \\
agricultural land & 1 & 1 & 0.5 & 1 \\
\hline
\end{tabular}

\subsubsection{Unequal legends}

The table may also be used to compare maps with unequal legends. The categorical similarity matrix can be either crisp (Table 4.8) or fuzzy (Table 4.9). Finding the appropriate correspondence between the two categorical definitions 
is not a straightforward task and is essentially subjective. In this chapter two heuristic approaches are followed that estimate the similarity matrix on the basis of the (crisp) contingency table. The first approach leads to a crisp similarity matrix in which categories are either equal or distinct, this approach in fact represents a reclassification of both maps towards a joint legend. The second approach yields a fuzzy categorical similarity matrix indicating with values between 0 and 1 the degree of similarity of legend classes.

Fritz \& See (2005) offer an alternative approach that is not based on statistics but instead on a questionnaire filled out by experts who judge the similarity from different perspectives. Yet an other approach is that of Ahlqvist (2005) who applies a formal analysis of semantic similarity of legend class definitions. The fuzzy set map comparison provides a method to apply these assessments of categorical similarity in combination with fuzziness of location.

Table 4.8 An example similarity matrix for the comparison of two maps with nonidentical legends and a crisp translation key

\begin{tabular}{llllll}
\hline map A $\downarrow:$ map B $\rightarrow$ & $\begin{array}{l}\text { high dens. } \\
\text { residential }\end{array}$ & $\begin{array}{l}\text { medium dens. } \\
\text { residential }\end{array}$ & $\begin{array}{l}\text { low dens. } \\
\text { residential }\end{array}$ & $\begin{array}{l}\text { Agricultur } \\
\text { e }\end{array}$ & forest \\
\hline pine forest & 0 & 0 & 0 & 0 & 1 \\
broad leaved forest & 0 & 0 & 0 & 0 & 1 \\
Urban & 1 & 1 & 1 & 0 & 0 \\
agricultural land & 0 & 0 & 0 & 1 & 0 \\
\hline
\end{tabular}

Table 4.9 An example similarity matrix for the comparison of two maps with nonidentical legends and a fuzzy translation key. In this example the distinction between 'low density residential' and 'agricultural land' cannot always be made and the definition of 'pine forest' in map A partially overlaps 'agriculture' in map $B$.

\begin{tabular}{llllll}
\hline map A $\downarrow:$ map B $\rightarrow$ & $\begin{array}{l}\text { high dens. } \\
\text { residential }\end{array}$ & $\begin{array}{l}\text { medium dens. } \\
\text { residential }\end{array}$ & $\begin{array}{l}\text { low dens. } \\
\text { residential }\end{array}$ & agriculture & forest \\
\hline pine forest & 0 & 0 & 0 & 0.3 & 1 \\
broad leaved forest & 0 & 0 & 0 & 0 & 1 \\
Urban & 1 & 1 & 1 & 0 & 0 \\
agricultural land & 0 & 0 & 0.5 & 1 & 0 \\
\hline
\end{tabular}

\section{Approach 1: Crisp categorical similarity}

The categorical similarity matrix is based on the contingency table such that a category in a legend is identical to the category it mostly overlaps with. 


$$
\mathrm{m}_{\mathrm{ij}}=\left\{\begin{array}{l}
1 \text { if } \mathrm{p}_{\mathrm{ij}}=\max _{\mathrm{i}=1}^{\mathrm{na}}\left|\mathrm{p}_{\mathrm{ij}}\right| \\
1 \text { if } \mathrm{p}_{\mathrm{ij}}=\max _{\mathrm{j}=1}^{\mathrm{nb}}\left|\mathrm{p}_{\mathrm{ij}}\right| \\
0 \text { otherwise }
\end{array}\right.
$$

where:

$\mathrm{m}_{\mathrm{ij}} \quad$ element in the categorical similarity matrix relating category $\mathrm{i}$ in the first map to category $\mathrm{j}$ in the second map.

$\mathrm{p}_{\mathrm{ij}} \quad$ element in the contingency table relating category $\mathrm{i}$ in the first map to category $\mathrm{j}$ in the second map.

na number of legend items in the first map

$\mathrm{nb}$ number of legend items in the second map

\section{Approach 2: Fuzzy categorical similarity}

In this approach, the categorical similarity is based on the proportion of overlap. The categorical similarity is determined as the maximum proportion that an element in the contingency takes, either in the row or the column.

$$
m_{i j}=\max \left(\frac{p_{i j}}{p_{i .}}, \frac{p_{i j}}{p_{. j}}\right)
$$

where:

$\mathrm{p}_{\mathrm{i}} \quad$ The proportion of category $\mathrm{i}$ in the first map.

$\mathrm{p}_{\mathrm{j}} \quad$ The proportion of category $\mathrm{j}$ in the second map

\subsection{Results}

To demonstrate the functioning of the different categorical similarity matrices, we apply them on two of the datasets of chapter 3 . The first data set is a synthetic one, constructed specifically to demonstrate the functioning of the fuzzy set map comparison.

\subsubsection{Case A: Synthetic dataset}

Comparison of the maps in the synthetic dataset (figure 4.1) yields the result given in figure 4.2, where grey levels indicate similarity (as in all subsequent greyscale maps). In order to obtain a better understanding of the nature of the differences figures $4.3 \mathrm{a} 1, \mathrm{~b} 1, \mathrm{c} 2$ and $\mathrm{d} 1$ give an overview of the differences per category. Figures $4.3 \mathrm{a} 2$, b2, c2 and d2 give the differences due to commission 
(in $m a p^{B}$ relative to $m a p^{A}$ ) and figures $4.3 \mathrm{a} 3, \mathrm{~b} 3, \mathrm{c} 3$ and $\mathrm{d} 3$ those due to omission. Table 4.10 gives the Fuzzy Kappa values resulting from the comparison, as well as regular Kappa values calculated according to Monserud \& Leemans (1992). It becomes clear that by considering proximity the order of the categories when sorted according to similarity changes. The similarity matrices that underlie the analysis for the whole map (figure 4.2) and for the category 'City' (figures 4.3b1, b2 and b3) are found in Table 4.11 For the other categories the similarity matrices are analogous.

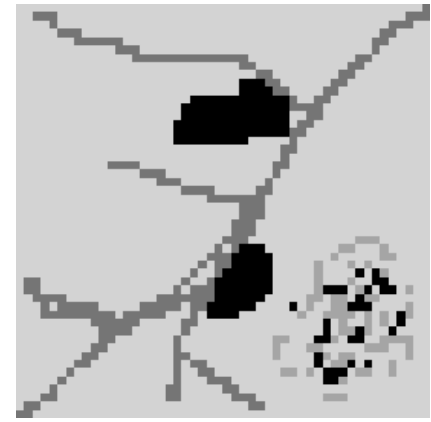

a. Map A

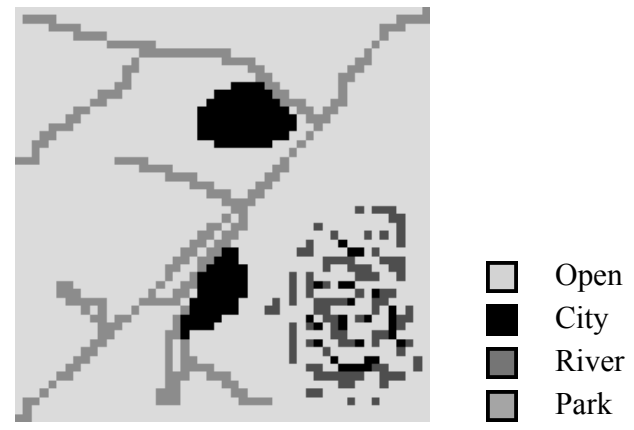

b. Map B

Figure 4.1 Synthetic dataset

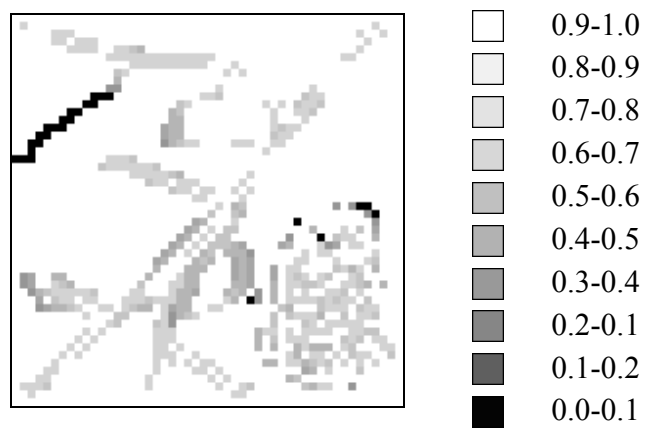

Figure 4.2 Fuzzy similarity, grey levels indicate local similarity, Fuzzy Kappa $=0.495$ 


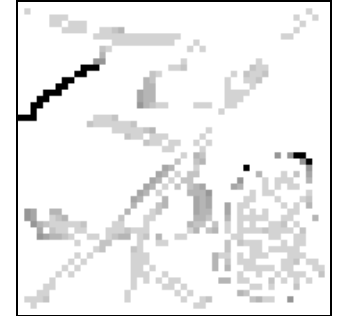

a1. Open, overall

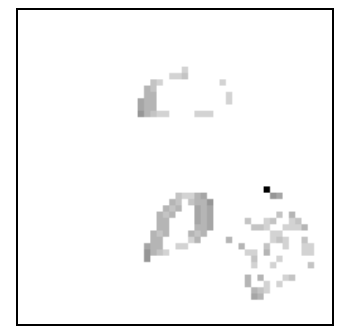

b1. City, overall

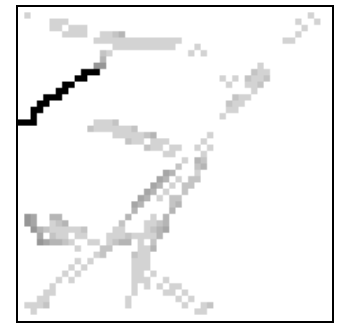

c1. River, overall

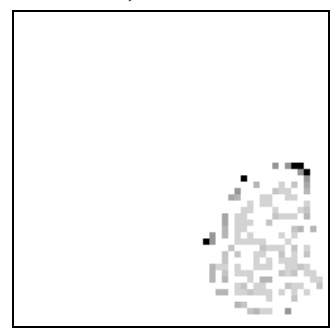

d1. Park, overall

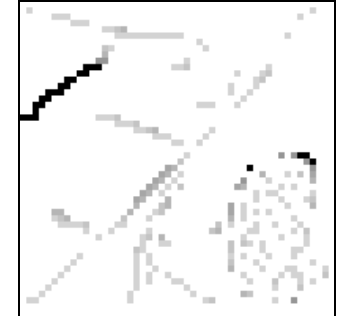

a2. Open, disappearance

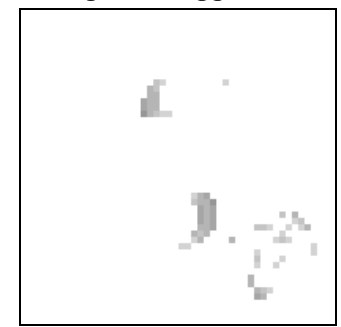

b2. City, disappearance

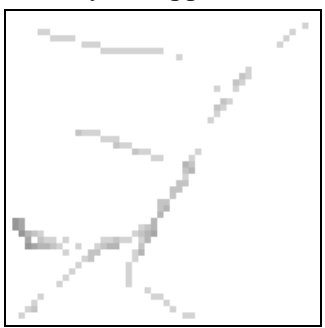

c2. City, disappearance

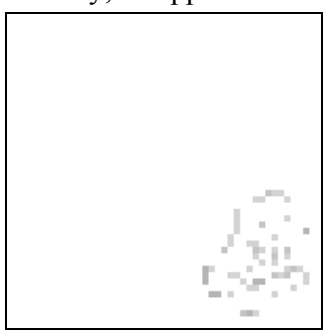

d2. Park, disappearance

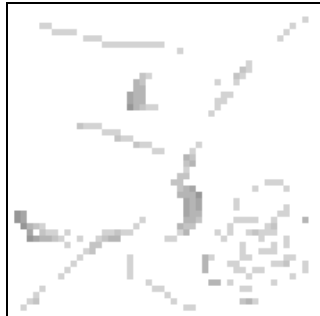

a3. Open, appearance

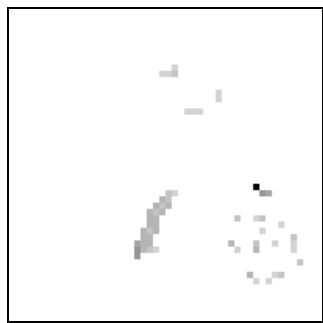

b3. City, appearance

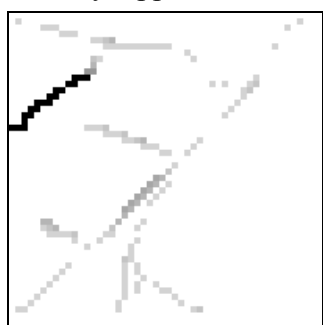

c3. City, appearance

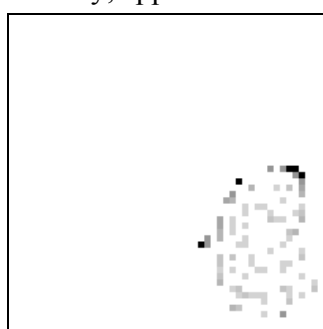

d3. Park, appearance

Figure 4.3 Disagreement per category and split into disagreement due to appearance (omission) and disappearance (commission).

The detailed similarity maps and statistics give information that cannot be derived directly from figure 4.2. In particular, we find that, according to table 4.10 , the strongest contribution to the difference is made by the presence of 'River' in $\operatorname{map}^{B}$ where it is not present in $\mathrm{map}^{A}$. Observing figure $4.3 \mathrm{c} 3$ it becomes clear that this is explained by the additional branch in the upper left area of the map. Furthermore, we learn that the maps are most similar with respect to the 'City' category. The similarity map of figure $4.3 \mathrm{~b} 1$ clarifies that for this category there is only one cell in the lowest class of similarity. 
Table 4.10 Per category comparison results

\begin{tabular}{lllll}
\hline $\mathrm{A} \downarrow \mathrm{B} \rightarrow$ & $\begin{array}{l}\text { Overall similarity } \\
\text { (Fuzzy Kappa) }\end{array}$ & $\begin{array}{l}\text { Disappearance } \\
\text { (Fuzzy Kappa) }\end{array}$ & $\begin{array}{l}\text { Appearance } \\
\text { (Fuzzy Kappa) }\end{array}$ & $\begin{array}{l}\text { Overall similarity } \\
\text { (Kappa) }\end{array}$ \\
\hline Open & 0.366 & 0.355 & 0.379 & 0.380 \\
City & 0.616 & 0.592 & 0.644 & 0.556 \\
River & 0.399 & 0.461 & 0.344 & 0.332 \\
Park & 0.485 & 0.544 & 0.446 & 0.184 \\
\hline
\end{tabular}

Table 4.11 Similarity matrices

a. Similarity matrix underlying results in b. Similarity matrix underlying results in figure figure 4.2

\begin{tabular}{lllll}
\hline $\mathrm{A} \downarrow \mathrm{B} \rightarrow$ & Open & City & River & Park \\
\hline Open & 1 & 0 & 0 & 0 \\
City & 0 & 1 & 0 & 0 \\
River & 0 & 0 & 1 & 0 \\
Park & 0 & 0 & 0 & 1 \\
\hline
\end{tabular}

c. Similarity matrix underlying results in figure $4.3 \mathrm{c} 2$

\begin{tabular}{lllll}
\hline $\mathrm{A} \downarrow \mathrm{B} \rightarrow$ & Open & City & River & Park \\
\hline Open & 1 & 1 & 1 & 1 \\
City & 0 & 1 & 0 & 0 \\
River & 1 & 1 & 1 & 1 \\
Park & 1 & 1 & 1 & 1 \\
\hline
\end{tabular}
$4.3 \mathrm{c} 1$

\begin{tabular}{lllll}
\hline $\mathrm{A} \downarrow \mathrm{B} \rightarrow$ & Open & City & River & Park \\
\hline Open & 1 & 0 & 1 & 1 \\
City & 0 & 1 & 0 & 0 \\
River & 1 & 0 & 1 & 1 \\
Park & 1 & 0 & 1 & 1 \\
\hline
\end{tabular}

d. Similarity matrix underlying results in figure $4.3 \mathrm{c} 3$

\begin{tabular}{lllll}
\hline $\mathrm{A} \downarrow \mathrm{B} \rightarrow$ & Open & City & River & Park \\
\hline Open & 1 & 0 & 1 & 1 \\
City & 1 & 1 & 1 & 1 \\
River & 1 & 0 & 1 & 1 \\
Park & 1 & 0 & 1 & 1 \\
\hline
\end{tabular}

\subsubsection{Case B: The Dublin model}

The second dataset (figure 4.4) is taken from practice. It consists of a land use map generated by a model and another which is considered 'ground truth'. The particular model is of the Constrained Cellular Automata (CCA) type (White et al. 1997) applied for the study of the urban development of Dublin, as part of the MOLAND project (White et al. 2000). Comparison of the two maps yields a similarity map (figure 4.5) and a Fuzzy Kappa of 0.905 which is considered satisfactory, because it means that the CCA model outperforms the null-model (chapter 3). 

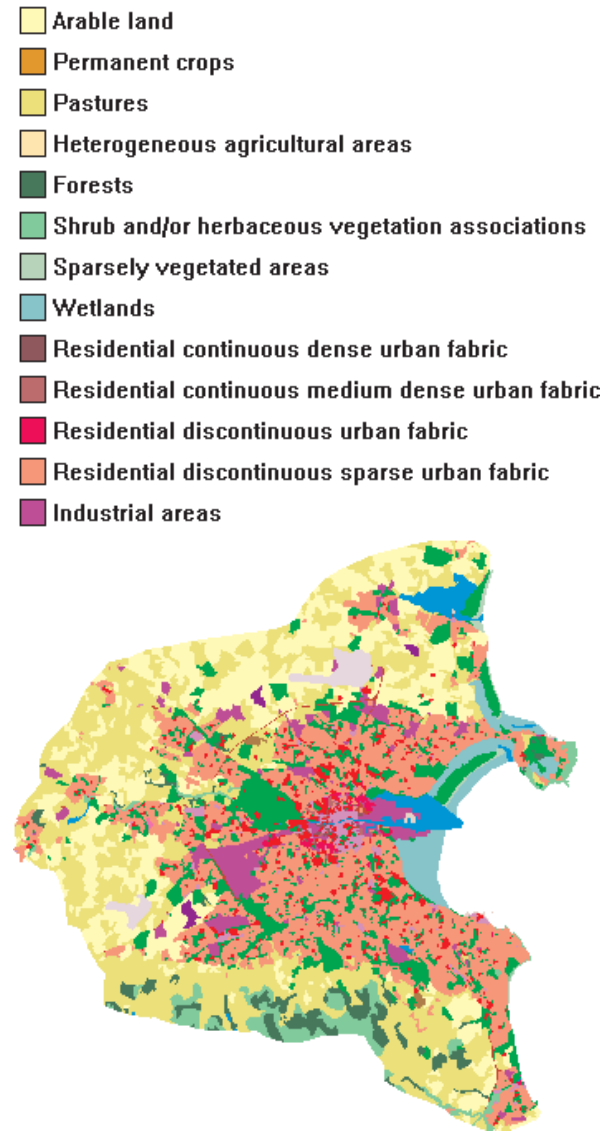

a. Ground truth map of Dublin in 1998
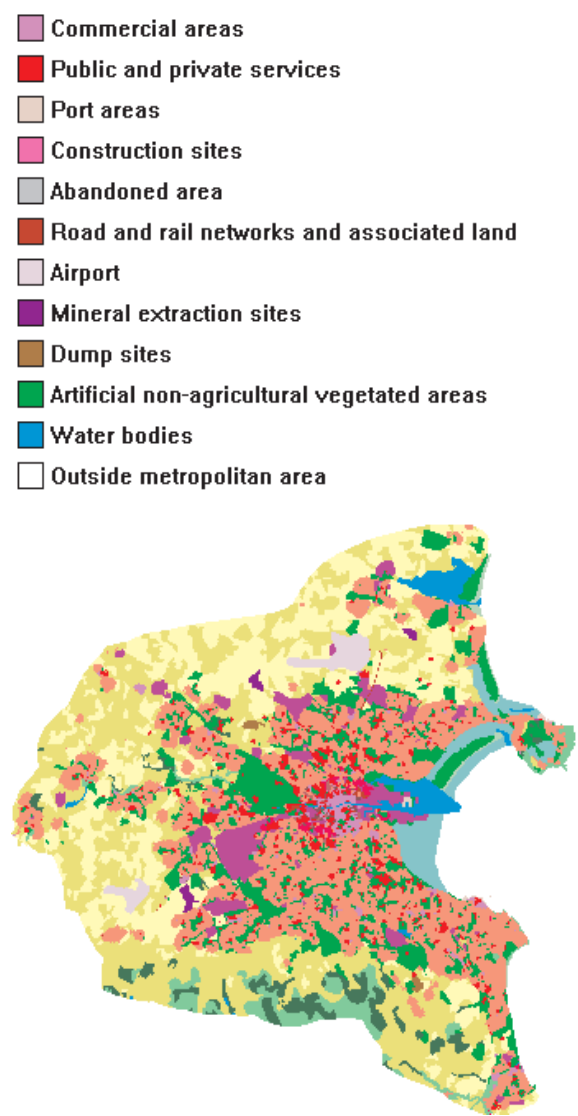

b. Simulated map of Dublin in 1998

Figure 4.4 Two maps of Dublin

The influence of differences pertaining to the category 'Road and rail networks and associated land' is considered a disturbance in the comparison, because it signifies a difference in the maps that the model is not expected or intended to prevent; The CCA model takes note of roads and railways in the calculation of accessibility, but takes them as exogenous input from separate network layers and does not predict their development. To investigate the impact of the disturbance, the difference with respect to this category is considered by temporarily setting all other categories equal to each other. Maybe more significantly, the similarity remaining when ignoring this source of difference is calculated, by temporarily setting the category 'Road and rail...' equal to all other categories. The results (figure 4.6) indicate that dismissing the contribution of 'Road and rail...' has a distinct visual impact on the distribution of the differences because the dominant linear elements disappear from the similarity map. Thus, we have gained more insight into the structure of the original similarity map. Despite the strong visual impact, the overall statistics 
are hardly affected; at the three-digit accuracy supported by the software, the Fuzzy Kappa does not change.

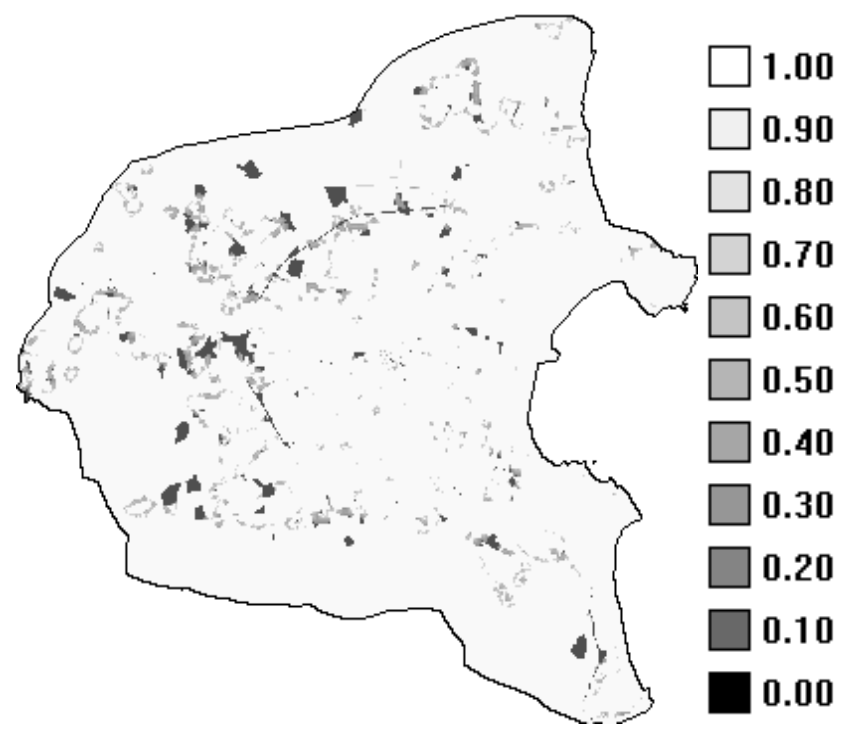

Figure 4.5 Fuzzy similarity

The categories 'Residential discontinuous sparse urban fabric' and 'Industrial areas' are of particular interest, because the model is aimed at their development and these categories displayed a severe change over the model period. Therefore, these two categories are examined separately. Considering the category 'Residential...' (figure 4.7) it appears that the differences due to omission are more serious than those due to commission. This is an indication that new residential cells are too often placed close to existing ones (minor differences due to commission) and too few new clusters are generated (major differences due to omission). This confirms the notion that, from a modeller's perspective, correctly 'seeding' new urban areas is more difficult than 'growing' existing areas.

An automated procedure might take this into account by weighting differences due to commission less than those by omission. This would mean that the procedure 'prefers' the combination of large errors due to commission and small errors of omission over the opposite and would thus lead to parameters more aimed at 'seeding' than at 'growing'. Admittedly, this is a speculative preposition and future research will need to point out the merit of applying asymmetrical similarity matrices in this manner. Figure 4.8 gives the results of weighting omission or commission stronger, analogous to table 4.7 but with 0.8 as the intermediate value. It demonstrates that by using different weights, other areas are highlighted as being most dissimilar. 


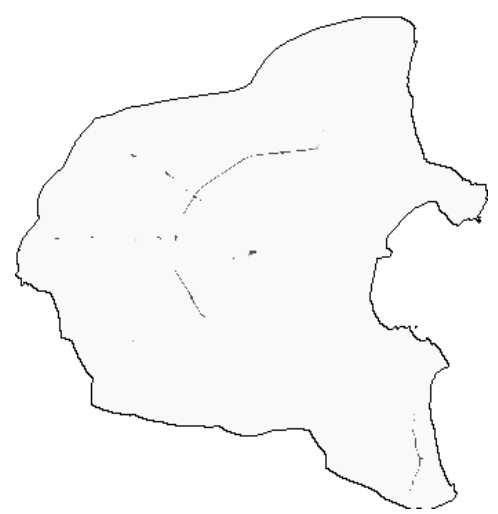

a. Fuzzy similarity of only 'Road and rail networks and associated land'

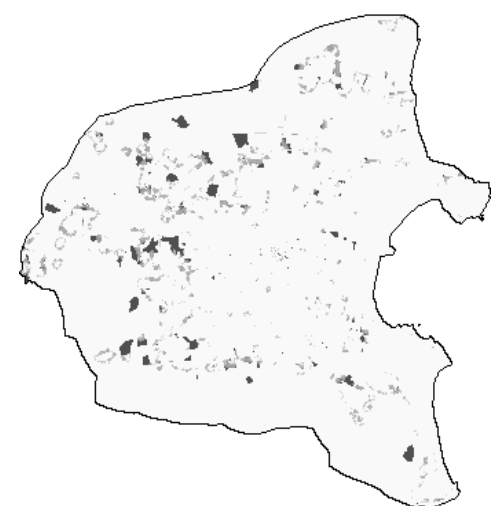

b. Fuzzy similarity ignoring 'Roads and rail networks and associated land'

Figure 4.6 Fuzzy similarity of 'Road and rail networks and associated land'

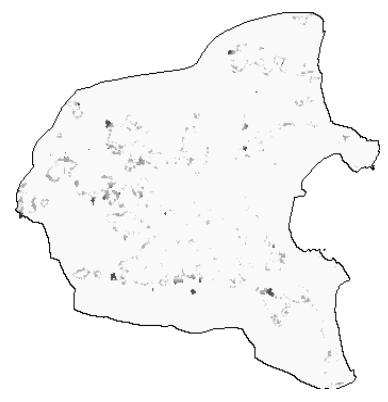

a. Overall

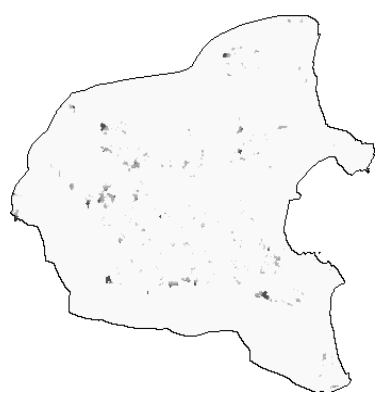

b. Omission

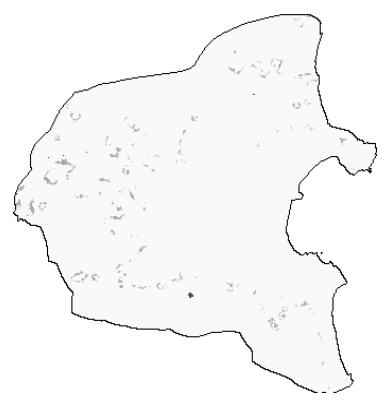

c. Commission

Figure 4.7 Difference with respect to the category 'Residential discontinuous sparse urban fabric'

The observation with regards to 'Industrial areas' (figure 4.9) is similar to that of 'Residential...'; however an additional observation is made here. Specifically in the northern part of the map it appears that the spatial distribution of clusters of omission is similar to that of the clusters of commission, indicating that although cell-to-cell the maps are clearly different (even when applying a tolerance for small spatial differences), the model does capture significant aspects of the spatial structure of industrial location. 


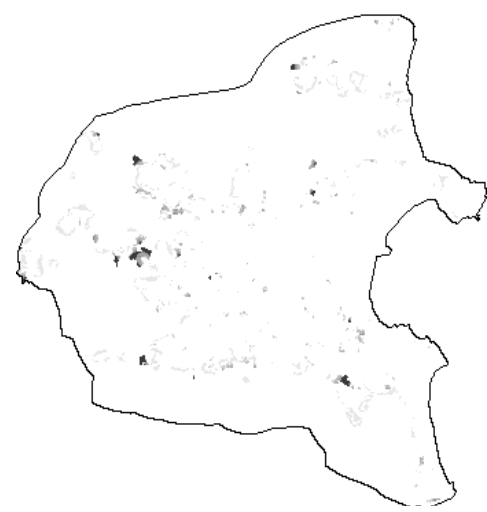

a. Omission is weighted stronger

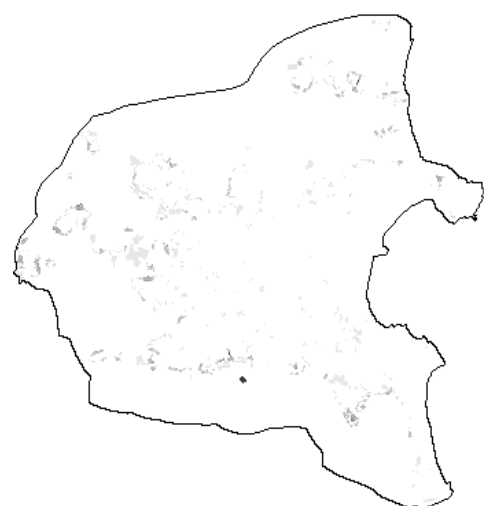

b. Commission is weighted stronger

Figure 4.8 Difference with respect to the category 'Residential discontinuous sparse urban fabric'.

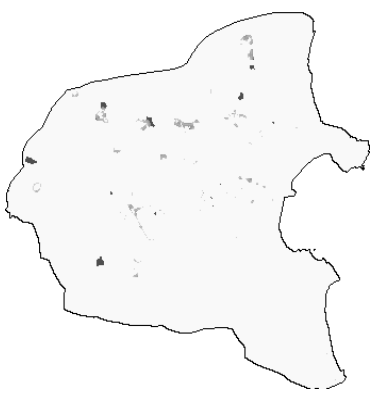

a. Overall

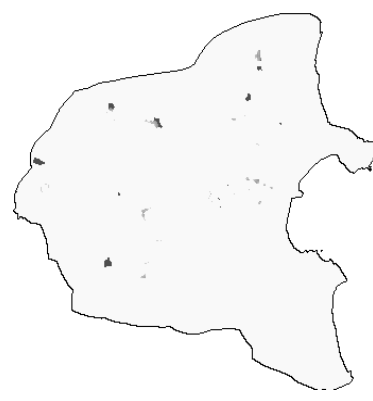

b. Omission

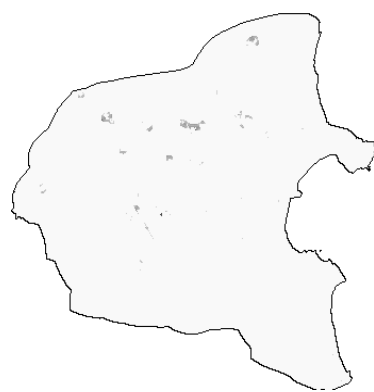

4. c. Commission

Figure 4.9 Difference with respect to category 'Industrial areas'.

\subsubsection{Case C: The Netherlands with unequal legends}

A third dataset consists of two maps of the Netherlands. The two maps are of different moments in time and obey different legends. Furthermore the maps are created following different procedures; the 1970 is based on topographic base maps and aerial photographs, whereas the 1989 map is based on a supervised classification of remote sensing imagery. Both maps have been resampled to a resolution of $500 \mathrm{~m}$. The maps and their respective legends are displayed in figure 4.10. 


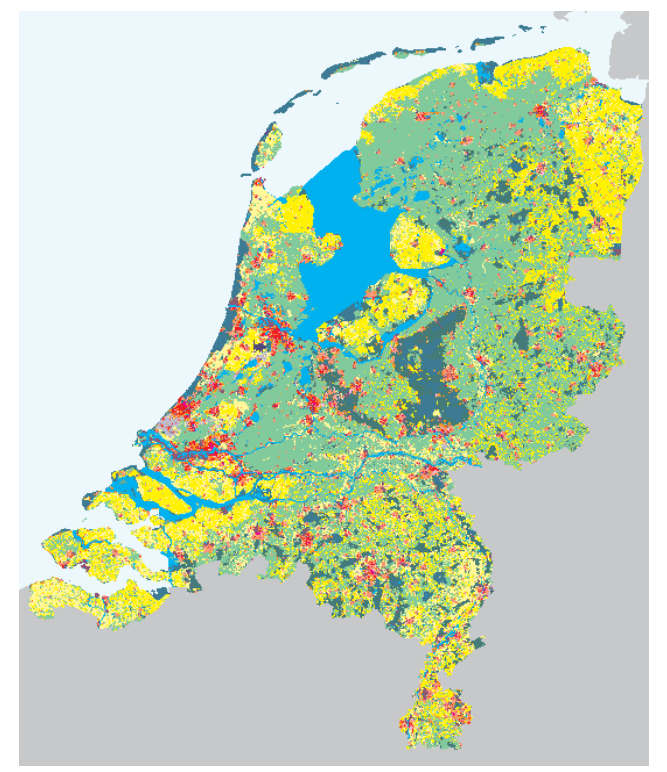

$\begin{array}{ll}\square & \text { Other agriculture } \\ \square \quad \text { Grassland } \\ \square \quad \text { Arable land } \\ \square \quad \text { Greenhouses } \\ \square \quad \text { Sparse residential } \\ \square \quad \text { Dense residential } \\ \square \quad \text { Industry } \\ \square \quad \text { Commercial } \\ \square \quad \text { Other services } \\ \square \quad \text { Forest } \\ \square \quad \text { Extensive grassland } \\ \square & \text { Nature } \\ \square & \text { Recreation } \\ \square & \text { Airport } \\ \square & \text { Fresh water } \\ \square & \text { Salt water } \\ \square & \text { Foreign }\end{array}$

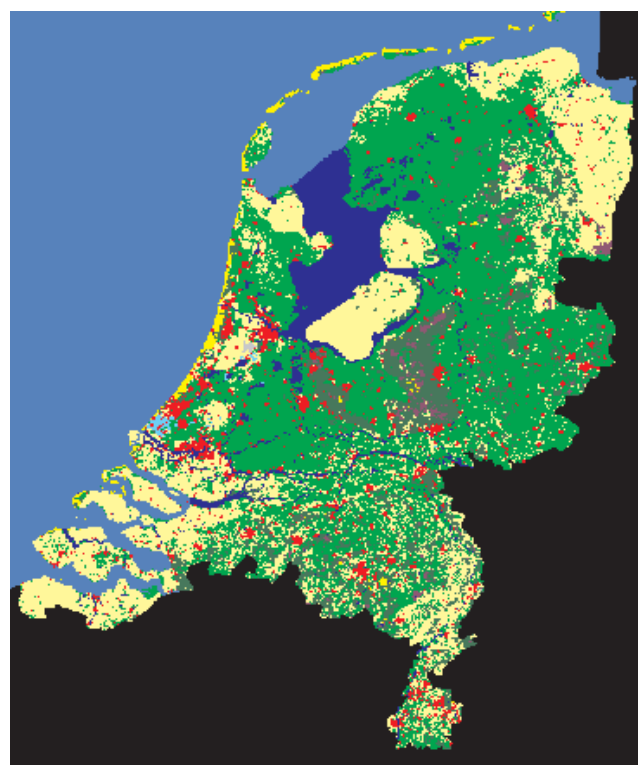

\begin{tabular}{|l|l}
\hline \multicolumn{1}{|c}{ Outside map } \\
\hline & Grass \\
\hline$\square$ & Arable land \\
\hline$\square$ & Heath \\
\hline$\square$ & Forest \\
\hline$\square$ & Build up \\
\hline$\square \quad$ & Fresh water \\
\hline$\square \quad$ & Sand \& dunes \\
\hline$\square \quad$ & Greenhouses \\
\hline$\square \quad$ & Airport \\
\hline$\square \quad$ Salt water
\end{tabular}

a. Land use 1989, 17 categories

b. Land use 1970, 11 categories

Figure 4.10 Two land use maps of the Netherlands. For different moments in time and with different legend classes

The categorical similarity matrices generated by both the crisp (table 4.12) and fuzzy (table 4.13) heuristic procedure give rise to the result result maps of figure 4.11. Four areas with strong differences according to both results are pointed out. In all four cases these represent real changes that took place over time and not disagreements in legend definition These are: 
- Zeeland 1: Large scale waterworks changed a body of water from salt water to fresh water.

- Zeeland 2: Nature development turned salt water into overgrown tidal shelves classified as nature.

- Flevoland: This province is new to the Netherlands (claimed from the sea in the period from 1930 to 1960 and still subject to large scale developments, both urbanization and nature development.

- Friesland: Large scale nature development was applied to build a 'natural' tidal inlet.

Table 4.12 Crisp categorical similarity matrix for two legends

\begin{tabular}{|c|c|c|c|c|c|c|c|c|c|c|c|}
\hline & 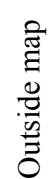 & $\begin{array}{l}n \\
\tilde{\Xi} \\
\tilde{0}\end{array}$ & $\frac{\frac{0}{0}}{\frac{\pi}{2}}$ & $\begin{array}{l}\bar{E} \\
\stackrel{\mathbb{N}}{\mathbb{N}}\end{array}$ & $\begin{array}{l}\overrightarrow{0} \\
0 \\
0 \\
0\end{array}$ & 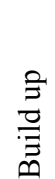 & $\begin{array}{l}\overline{\mathbf{D}} \\
\bar{\pi} \\
\overline{3} \\
\bar{w} \\
0 \\
0\end{array}$ & 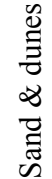 & $\begin{array}{l}\text { v } \\
0 \\
0 \\
0 \\
\tilde{0} \\
0 \\
0 \\
0\end{array}$ & 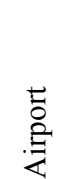 & $\begin{array}{l}\bar{\Phi} \\
\bar{\sigma} \\
3 \\
\bar{E} \\
\tilde{D}\end{array}$ \\
\hline Other agriculture & & & 1 & & & & & & & & \\
\hline Grassland & & 1 & & & & & & & & & \\
\hline Arable land & & & 1 & & & & & & & & \\
\hline Greenhouses & & & & & & & & & 1 & & \\
\hline Sparse residential & & & & & & 1 & & & & & \\
\hline Dense residential & & & & & & 1 & & & & & \\
\hline Industry & & & 1 & & & & & & & & \\
\hline Commercial & & & & & & 1 & & & & & \\
\hline Other services & & & & & & 1 & & & & & \\
\hline Forest & & & & & 1 & & & & & & \\
\hline Extensive grassland & & 1 & & & & & & & & & \\
\hline Nature & & & & 1 & 1 & & & 1 & & & \\
\hline Recreation & & 1 & & & & & & & & & \\
\hline Airport & & & & & & & & & & 1 & \\
\hline Fresh water & & & & & & & 1 & & & & \\
\hline Salt water & & & & & & & & & & & 1 \\
\hline Foreign & 1 & & & & & & & & & & \\
\hline
\end{tabular}


Table 4.13 Fuzzy categorical similarity matrix for two legends

\begin{tabular}{|c|c|c|c|c|c|c|c|c|c|c|c|}
\hline & 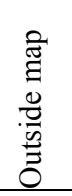 & 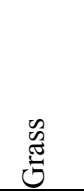 & $\frac{\frac{0}{3}}{\frac{\pi}{2}}$ & 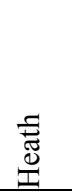 & 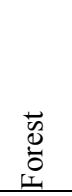 & 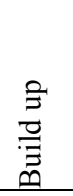 & 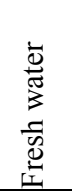 & 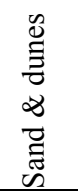 & 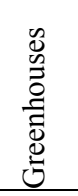 & 总 & $\begin{array}{l}\bar{\Xi} \\
\bar{\sigma} \\
3 \\
\bar{\Xi} \\
\tilde{\omega} \\
\end{array}$ \\
\hline Other agriculture & & 0.31 & 0.60 & 0.04 & 0.04 & 0.06 & 0.01 & 0.01 & 0.04 & 0.09 & 0.01 \\
\hline Grassland & & 0.86 & 0.16 & & 0.04 & 0.03 & 0.01 & & & & \\
\hline Arable land & & 0.26 & 0.72 & 0.01 & 0.02 & 0.01 & & & & & \\
\hline Greenhouses & & 0.12 & 0.25 & & 0.01 & 0.08 & 0.01 & & 0.95 & & \\
\hline $\begin{array}{l}\text { Sparse } \\
\text { residential }\end{array}$ & & 0.21 & 0.20 & & 0.04 & 0.54 & 0.01 & 0.01 & & & \\
\hline $\begin{array}{l}\text { Dense } \\
\text { residential }\end{array}$ & & 0.17 & 0.15 & & & 0.68 & & & & & \\
\hline Industry & & 0.24 & 0.38 & 0.02 & 0.06 & 0.24 & 0.05 & 0.01 & & 0.13 & 0.01 \\
\hline Commercial & & 0.13 & 0.17 & & 0.04 & 0.65 & & 0.01 & & 0.02 & \\
\hline Other services & & 0.23 & 0.19 & & 0.24 & 0.33 & & 0.01 & & & \\
\hline Forest & & 0.06 & 0.05 & 0.23 & 0.85 & & & 0.04 & & & \\
\hline $\begin{array}{l}\text { Extensive } \\
\text { grassland }\end{array}$ & & 0.45 & 0.13 & 0.02 & 0.30 & 0.01 & 0.02 & 0.04 & & & 0.03 \\
\hline Nature & & 0.12 & 0.09 & 0.65 & 0.33 & 0.01 & 0.02 & 0.77 & & 0.01 & 0.04 \\
\hline Recreation & & 0.37 & 0.23 & 0.01 & 0.19 & 0.14 & 0.04 & 0.02 & & & \\
\hline Airport & & 0.15 & 0.07 & 0.02 & 0.11 & & & & & 0.74 & \\
\hline Fresh water & & 0.06 & 0.04 & 0.01 & & 0.02 & 0.92 & 0.02 & 0.01 & & 0.09 \\
\hline Salt water & & & & & & & & 0.06 & & & 1.00 \\
\hline Foreign & 1.00 & 0.01 & 0.01 & 0.01 & 0.01 & & & 0.02 & & & \\
\hline
\end{tabular}

The difference between the two approaches is reflected in the comparison maps. The crisp approach hardens the similarity found in the contingency table and thus recognizes large areas as identical. The fuzzy approach retains the uncertainty that follows from the less than perfect fit between the two maps and thus presents a less pronounced overall picture.

The correspondence between real major land use changes and differences observed in the two maps is an indication that the relation found between legend categories is adequate. 


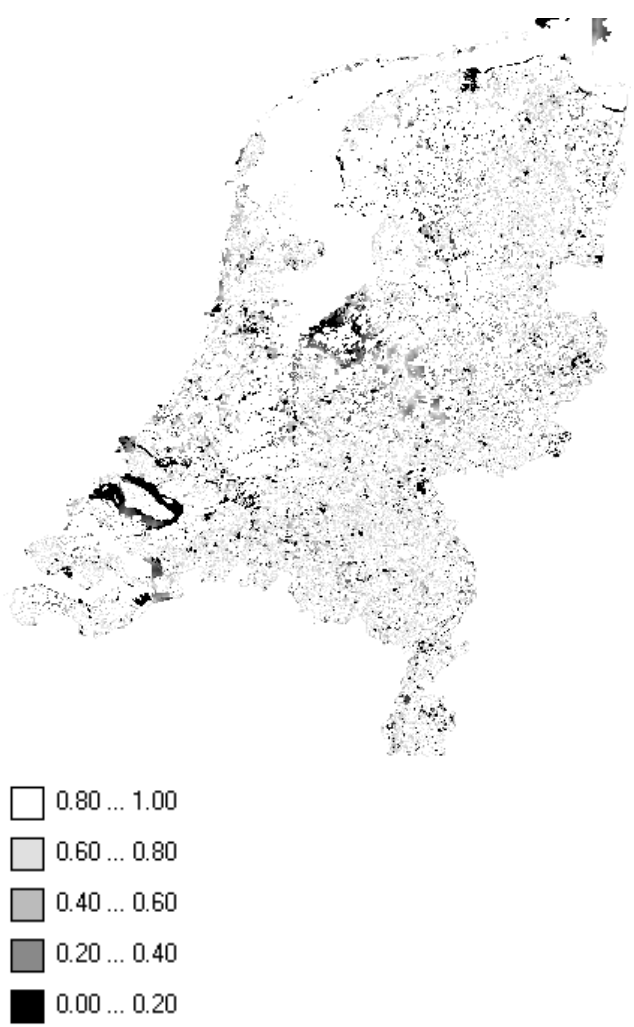

a. Based on a crisp categorical similarity matrix

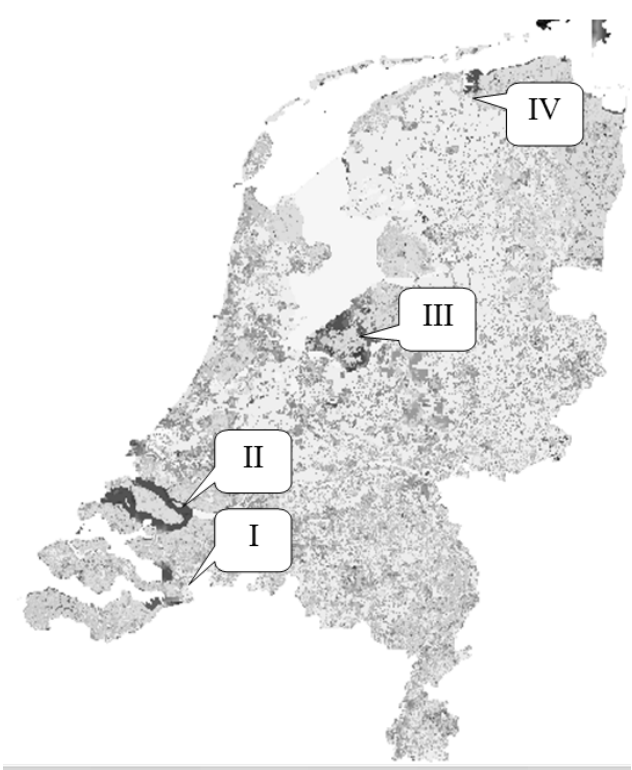

I. Zeeland 1

II. Zeeland 2

III Flevoland

IV Friesland

b. Based on a fuzzy categorical similarity matrix

Figure 4.11 Fuzzy Similarity of two maps with unequal legends

\subsection{Conclusion}

Chapter 3 introduced a fuzzy set map comparison method that applies a categorical similarity matrix to account for the fact that some categories are more similar than others. The current chapter points out that the similarity matrix has significance beyond this purpose. To some extent, the further applications are pragmatic, in particular when the categorical similarity matrix is used to group categories together or perform a per category comparison. This could also be achieved by a reclassification of the source data prior to a fuzzy set map comparison as presented in chapter 3 .

The further applications of the matrix also embrace true methodological improvements. The use of asymmetrical categorical similarity matrices allows for the separate treatment of errors due to commission and omission, in line with the distinction between users and producers accuracy of cell-by-cell map comparison that are discussed in chapter 2 . 


\section{Chapter 4}

By using categorical similarity values between 0 and 1 it becomes possible to weight different aspects of similarity. This stands in contrast with the methods discussed so far, where the general drift has been to untangle different aspects of similarity, rather than confound them. A comprehensive and balanced account of similarity is useful however for model analytical tasks that require only a single metric of goodness-of-fit.

The similarity matrix proves to be a useful instrument for comparing maps with unequal legends. Furthermore the matrix can be used to single out or weight categories or groups of categories in the comparison; Finally, it can make the distinction between differences due to omission and commission. Thus, the fuzzy set map comparison not only offers insight into the severity and spatial distribution of differences, but also the nature of these differences.

Application to the same dataset that was also used in chapter 2 provides insights that were not obvious without exploring the possibilities of highlighting and weighting different types of categorical similarity.

The comparison of maps with unequal legends is useful for those situations where multi-temporal data are available from different sources, or have not been collected according to the same standards. In these cases the difficulty is to discern differences due to real changes from differences in the legend. In the presented case land use maps as far as 19 years apart were compared and the large differences that appear reflect major land use changes that took place over this period.

The similarity matrix offers a practically unlimited number of comparison settings. There is little point in calculating all of these every time a pair of maps is compared. Therefore, the aim of the method is to illuminate differences and similarities found in a pair of maps through interactive, explorative use. It also means that although the methods are explicitly defined and repeatable, the idea of objective map comparison is a fiction. Comparison is based upon the subjective interpretation of maps, which is expressed firstly by the selection of the methodology and secondly by the parameter settings (if any) that are applied.

Visual inspection of the Dublin case revealed a similarity in the size and spatial distribution of industrial areas. Such similarity cannot be recognized by the fuzzy set map comparison and provides motivation for further development of map comparison methods aimed at structural similarity. The development of such methods is the topic of chapter 6 . 


\section{$5 \quad$ Balancing presence and structure}

\subsection{Introduction}

Two juxtaposed approaches to map comparison are the measurement of cell-bycell agreement of presence the global comparison of landscape structure. This chapter recognizes that these are the extremes of a continuous scale and investigates the options along that scale on the basis of moving window based analysis.

For raster maps the comparison of overlap means cell-by-cell comparison as discussed in chapter 2 . This approach is particularly common (and appropriate) in remote sensing accuracy assessment. (Foody 2002). At the other side of the spectrum lies the practice of comparing maps at the landscape level. Summaries of landscape structure allow a mean of comparing maps, even those that do not overlap in space. Landscape metrics such as mean patch size, entropy and mean shape index find application in landscape ecology. Urban geographers have relied on measures such as cluster size distribution and fractal dimension (Batty \& Longley 1994).

This chapter explores the idea that landscape structure is not homogenous over space and hence that some locations may be more similar in terms of structure than others. By accounting for near overlap the fuzzy set map comparison of chapter 3 already takes structure into consideration. The current chapter gives a more generic framework and includes metrics of configuration.

Figure 5.1 shows two pairs of maps that in a typical contingency table based approach would be classified as fully distinct (Kappa $=-1$ ). From a landscape structure perspective both pairs of maps represent full agreement because patches have the same size, shape and relative position (if direction is ignored). From a visual analysis one might conclude that the first pair is more similar than the second because the displacement of the black circles is smaller.

This chapter introduces several methods that consider spatial structure and overlap simultaneously. As in the fuzzy set map comparison, a central idea is that a location is defined by its neighbourhood and that cells closer to the centre of the neighbourhood have a stronger influence than those at the edge. 


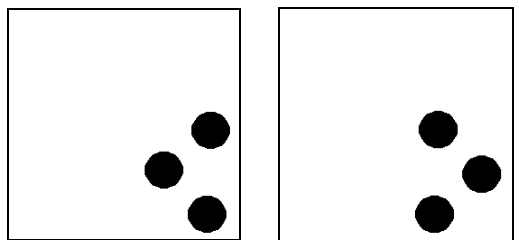

a. First pair of maps

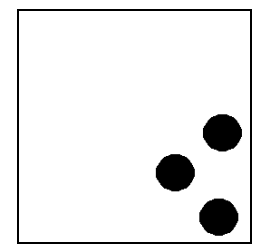

b. Second pair of maps

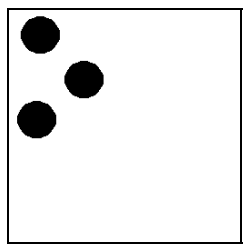

Figure 5.1 Two pairs of maps that are both considered fully distinct from the perspective of overlap and identical from the perspective of landscape structure. Balanced analysis should find the first pair more similar.

Thus, the methods make use of a distance weighted moving window parameterized by halving distance. In the limits the methods are cell-by-cell comparisons (when the halving distance approaches 0 ) or landscape level comparisons (when the halving distance approaches infinity). In between, the methods will consider the first pair more similar than the second pair. Figure 5.2 illustrates how similarity depends on halving distance.

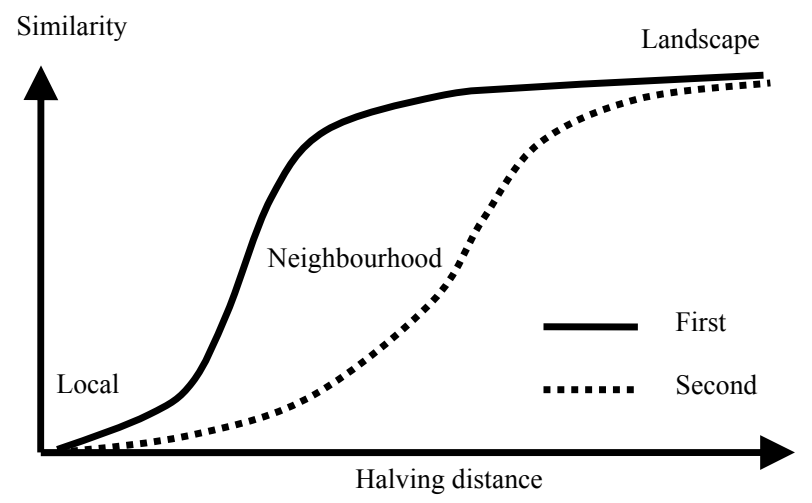

Figure 5.2 Moving windows based similarity of the two pairs of maps in figure 5.1 as a function of halving distance

The following sections will introduce 'neighbourhood variants' of both overlap based comparison methods (contingency table, kappa statistic) and structure comparisons. The structure metrics are based on both configuration (patch size, edge length, fractal dimension and shape index) and composition metrics (abundance and diversity). 


\subsection{Method}

\subsubsection{Defining neighbourhoods and local abundance}

The notion of neighbourhoods is central to all comparison methods that will be introduced in this chapter. Therefore, this section first defines neighbourhoods and the key variable of local abundance which summarizes the neighbourhood.

The maps that we consider are raster maps that cover the same area, which means that they consist of cells that are defined by a row and column number coordinate. Let $C$ be the set of all cells on the maps:

$$
\begin{aligned}
& \mathrm{C}=\left\{\mathrm{c}_{1}, \mathrm{c}_{2} \cdots \mathrm{c}_{\mathrm{n}}\right\} \\
& \mathrm{c}_{\mathrm{i}} \in \mathbb{Z}^{2}
\end{aligned}
$$

where:

$\mathrm{n}$ the number of cells on the maps.

The neighbourhood of a cell consists of all cells within radius $r$ of that cell. Let $N B H$ be the set of neighbourhoods for all cells in $C$.

$$
\begin{aligned}
& \mathrm{NBH}=\left\{\mathrm{nbh}_{1}, \mathrm{nbh}_{2}, \cdots \mathrm{nbh}_{\mathrm{n}}\right\} \\
& \mathrm{nbh}_{\mathrm{i}}=\left\{\mathrm{nbh}_{\mathrm{i}, 1}, \mathrm{nbh}_{\mathrm{i}, 1}, \cdots, \mathrm{nbh}_{\mathrm{i}, \mathrm{t}_{\mathrm{i}}}\right\} \\
& \mathrm{nbh}_{\mathrm{i}, \mathrm{j}} \in \mathrm{C} \mid \mathrm{d}_{\mathrm{i}, \mathrm{j}} \leq \mathrm{r} \\
& \mathrm{d}_{\mathrm{i}, \mathrm{j}}=\left\|\mathrm{nbh}_{\mathrm{i}, \mathrm{j}}-\mathrm{c}_{\mathrm{i}}\right\| * \mathrm{u}
\end{aligned}
$$

where:

$\mathrm{nbh}_{\mathrm{i}, \mathrm{j}} \quad$ the $\mathrm{j}$-th neighbour of the $\mathrm{i}$-th cell in $\mathrm{C}$.

$t_{i} \quad$ number of cells in the neighbourhood of the $i$-th cell in $C$

$d_{i, j} \quad$ Euclidean distance expressed between the $i$-th cell and its $j$-th neighbour

$\mathrm{u} \quad$ cellsize, converts the distance from cell units to real units.

For convenience, $u$ is assumed to be 1 , which means that all distances are measured in cell units. The number $t_{i}$ is not the same for all cells because at the edges of the map, neighbourhoods consist of fewer cells.

The neighbourhoods are distance weighted, thus every cell in each neighbourhood is assigned a weight $w_{i, j}$ on the basis of the distance decay function $f(d)$. 


$$
\begin{aligned}
& f(d)=\frac{1}{2}^{d / x} \\
& w_{i, j}=f\left(d_{i, j}\right)
\end{aligned}
$$

Thus the neighbourhood is set by 2 parameters; halving distance $\alpha$ and radius $r$. From a mathematical point of view it would be perfectly acceptable to apply an infinitely large radius, considering that the volume under an exponential distance decay surface is a limited real value. This would mean that the neighbourhood of each cell consists of all cells on the map $\left(n b h_{i}=C\right.$ for all $\left.i\right)$. In practice, calculation times would be out of bounds. Thus, the two parameters have a different role; $\alpha$ is a parameter with a conceptual meaning (the scale of the analysis) whereas $r$ has a technical meaning (the precision of the analysis). Throughout this chapter, a radius of 5 times the halving distance is applied. This corresponds to a cut-off value for $w_{i, j}$ of $(1 / 2)^{5}=0.03125$.

On the basis of the definition of the neighbourhood and weights an abundance map can be derived from a categorical map. The abundance map specifies for each location to what extent the neighbourhood is defined by each category. Thus every location corresponds to a vector of values indicating for each category the degree of belonging (Equation 5.5).

$$
\begin{aligned}
& \mathrm{P}_{\mathrm{i}}^{\mathrm{M}}=\left\{\mathrm{p}_{\mathrm{i}, 1}^{\mathrm{M}}, \mathrm{p}_{\mathrm{i}, 2}^{\mathrm{M}}, \cdots \mathrm{p}_{\mathrm{i}, \mathrm{y}^{\mathrm{M}}}^{\mathrm{M}}\right\} \\
& \mathrm{p}_{\mathrm{i}, \mathrm{k}}^{\mathrm{M}} \in[0,1]
\end{aligned}
$$

where:

$\mathrm{p}_{\mathrm{i}, \mathrm{k}}^{\mathrm{M}} \quad$ abundance at cell $\mathrm{i}$ in map $\mathrm{M}$ for legend category $\mathrm{k}$

$\mathrm{y}^{\mathrm{M}} \quad$ is the number of categories in the legend of map $M$

Let $V(M, c)$ be the function that reads the legend index number for the category found at cell $c$ in map $M$. Then the abundance of a category can be calculated as:

$$
\mathrm{p}_{\mathrm{i}, \mathrm{k}}^{\mathrm{M}}=\frac{\sum_{\mathrm{j}=1}^{\mathrm{t}_{\mathrm{i}}} \mathrm{w}_{\mathrm{i}, \mathrm{j}} * \delta_{\mathrm{k}, \mathrm{V}\left(\mathrm{M}, \mathrm{nbh} \mathrm{h}_{\mathrm{i}, \mathrm{j}}\right)}}{\sum_{\mathrm{j}=1}^{\mathrm{t}_{\mathrm{i}}} \mathrm{w}_{\mathrm{i}, \mathrm{j}}}
$$

Where

$\delta_{\mathrm{a}, \mathrm{b}} \quad$ the Kronecker delta, taking value 1 if $\mathrm{a}$ and $\mathrm{b}$ are equal and 0 otherwise. 
Calculation of local abundance according to Equation 5.6 means that applications that give considerable weight to the neighbourhood will automatically loose focus of the cell level. This may well be intended, but it is not strictly necessary. In chapter 3 the fuzzy neighbourhood vector prevented just this. The premise of that representation is that the cell is fully defined by its own value and to a smaller extent, also by the cells in the neighbourhood. In other words it is possible to consider large neighbourhoods and give them a substantial weight in the analysis without diluting the information contained at the cell level. This representation of multiple truths is typical of fuzzy set analysis. Local abundance according to this fuzzy representation is defined by Equation 5.7.

$$
\begin{aligned}
& P_{i}^{\text {fuzzy, }, M}=\left\{p_{i, 1}^{\text {fuzzy }, M}, p_{i, 2}^{\text {fuzzy }, M}, \cdots p_{i, y}^{\text {fuzzy }, M}\right\} \\
& p_{i, k}^{\text {fuzzy,M }}=\max _{j=1}^{t_{i}} w_{i, j} \delta_{v\left(M, n b h_{i, j}\right), k}
\end{aligned}
$$

Equation 5.7

\subsubsection{Neighbourhood overlap and similarity of composition}

Overlap based methods compare cell-by-cell whether values on two maps are similar. In the neighbourhood variants this amounts to evaluating cell-by-cell whether neighbourhoods are similar.

Composition metrics of landscape summarize the distribution of classes over the whole map and subsequently compare the summaries. In the neighbourhood variant the local distribution of classes is summarized and compared.

Thus, in their neighbourhood variants, overlap comparison and landscape composition metrics are identical.

This chapter will compare local abundance in terms of presence by means of the Euclidean distance (Equation 5.8). For alternative distance metrics see (Shalan et al. 2004). Note that the fuzzy set map comparison methods in chapters 3 and 4 are in fact local abundance comparisons as well.

$$
\mathrm{D}_{\mathrm{i}}^{\text {Euclid }}=\left\|\mathrm{P}_{\mathrm{i}}^{\mathrm{A}}-\mathrm{P}_{\mathrm{i}}^{\mathrm{B}}\right\|
$$

Equation 5.8

The structure of local abundance may be summarized by different structure metrics of composition. These metrics typically express the diversity of the composition. Shannon diversity (entropy) is such a metric originating from information theory and will be applied in this chapter. The difference in Shannon diversity is calculated according to the following equation: 
Chapter 5

$$
\begin{aligned}
& D_{i}^{\text {Shannon }}=\operatorname{Shannon}\left(p_{i}^{B}\right)-\operatorname{Shannon}\left(p_{i}^{A}\right) \\
& \operatorname{Shannon}\left(p_{i}^{M}\right)=-\sum_{k=1}^{y} p_{i, k}^{M} \ln \left(p_{i, k}^{M}\right)
\end{aligned}
$$

Equation 5.9

\subsubsection{Neighbourhood overlap summarized in contingency tables}

Chapter 2 saw how cell-by-cell differences can be summarized in a contingency table. That contingency table is the basis for many metrics including Kappa, Klocation and Khisto. Could a contingency table on the basis of local abundance be just as informative? Instead of summarizing cell-by-cell differences, this matrix would summarize neighbourhood-by-neighbourhood differences. The methodology for compiling such matrices is already available in two papers aiming at the accuracy assessment of soft classified maps (Binaghi et al. 1999, Lewis \& Brown 2001). In particular the fuzzy set based contingency table of Binahi et al. (1999) offers a robust approach since it does not mix propbability and fuzzy set theory like Lewis \& Brown (2001). Their confusion matrix, $C_{\text {binaghi }}$, is derived according to Equation 5.10.

$$
\begin{aligned}
& \mathrm{C}^{\text {binaghi }}=\left[\begin{array}{cccc}
\mathrm{c}_{1,1} & \mathrm{c}_{1,2} & \cdots & \mathrm{c}_{1, \mathrm{y}^{\mathrm{B}}} \\
\mathrm{c}_{2,1} & \mathrm{c}_{2,2} & \cdots & \mathrm{c}_{2, \mathrm{y}^{\mathrm{B}}} \\
\vdots & \vdots & \ddots & \vdots \\
\mathrm{c}_{\mathrm{y}^{\mathrm{A}}, 1} & \mathrm{c}_{\mathrm{y}^{\mathrm{A}}, 2} & \cdots & \mathrm{c}_{\mathrm{y}^{\mathrm{A}}, \mathrm{y}^{\mathrm{B}}}
\end{array}\right] \\
& \mathrm{c}_{\mathrm{a}, \mathrm{b}}=\sum_{\mathrm{i}=1}^{\mathrm{n}} \min \left(\mathrm{p}_{\mathrm{i}, \mathrm{a}}^{\mathrm{A}}, \mathrm{p}_{\mathrm{i}, \mathrm{b}}^{\mathrm{B}}\right)
\end{aligned}
$$

Equation 5.10

Binaghi et al. (1999) use the confusion matrix as input to derive several summary statistics including overall accuracy $(O A)$. Here a slight variation $\left(O A^{L Q}\right)$, is proposed that can be conveniently expressed as the product of location and quantity based agreement. $O A^{L Q}$ measures the overlap in abundance relative to the total abundance found in either of the maps. It is thus the equivalent of the percentage of agreement.

$$
\mathrm{OA}^{\mathrm{LQ}}=\frac{\sum_{\mathrm{k}=1}^{\mathrm{y}} \mathrm{c}_{\mathrm{k}, \mathrm{k}}}{\max \left(\sum_{\mathrm{k}=1}^{\mathrm{y}} \sum_{\mathrm{i}=1}^{\mathrm{n}} \mathrm{p}_{\mathrm{i}, \mathrm{k}}^{\mathrm{A}}, \sum_{\mathrm{k}=1}^{\mathrm{y}} \sum_{\mathrm{i}=1}^{\mathrm{n}} \mathrm{p}_{\mathrm{i}, \mathrm{k}}^{\mathrm{B}}\right)}
$$

where:

$k \quad$ index over the legend categories 
$y \quad$ the number of categories.

In analogy to Khisto and Klocation of chapter 2, differences of location are measured relative to the maximum agreement given the total presence of categories in both maps. The statistics $O A^{L}$ and $O A^{Q}$ express respectively the location and the quantity component of $O A^{L Q}$ such that $O A^{L Q}=O A^{L *} O A^{Q}$

$$
\begin{aligned}
& \mathrm{OA}^{\mathrm{L}}= \frac{\sum_{\mathrm{k}=1}^{\mathrm{y}} \mathrm{c}_{\mathrm{k}, \mathrm{k}}}{\sum_{\mathrm{k}=1}^{\mathrm{y}} \min \left(\sum_{\mathrm{i}=1}^{\mathrm{n}} \mathrm{p}_{\mathrm{i}, \mathrm{k}}^{\mathrm{A}}, \sum_{\mathrm{i}=1}^{\mathrm{n}} \mathrm{p}_{\mathrm{i}, \mathrm{k}}^{\mathrm{B}}\right)} \\
& \mathrm{OA}^{\mathrm{Q}}=\frac{\sum_{\mathrm{k}=1}^{\mathrm{y}} \min \left(\sum_{\mathrm{i}=1}^{\mathrm{n}} \mathrm{p}_{\mathrm{i}, \mathrm{k}}^{\mathrm{A}}, \sum_{\mathrm{i}=1}^{\mathrm{n}} \mathrm{p}_{\mathrm{i}, \mathrm{k}}^{\mathrm{B}}\right)}{\max \left(\sum_{\mathrm{k}=1}^{\mathrm{y}} \sum_{\mathrm{i}=1}^{\mathrm{n}} \mathrm{p}_{\mathrm{i}, \mathrm{k}}^{\mathrm{A}}, \sum_{\mathrm{k}=1}^{\mathrm{y}} \sum_{\mathrm{i}=1}^{\mathrm{n}} \mathrm{p}_{\mathrm{i}, \mathrm{k}}^{\mathrm{B}}\right)}
\end{aligned}
$$

Equation 5.13

The accuracy can also be assessed for a single category $k$ as:

$$
\begin{aligned}
& \mathrm{OA}_{\mathrm{k}}^{\mathrm{LQ}}=\frac{\mathrm{c}_{\mathrm{k}, \mathrm{k}}}{\max \left(\sum_{\mathrm{i}=1}^{\mathrm{n}} \mathrm{p}_{\mathrm{i}, \mathrm{k}}^{\mathrm{A}}, \sum_{\mathrm{i}=1}^{\mathrm{n}} \mathrm{p}_{\mathrm{i}, \mathrm{k}}^{\mathrm{B}}\right)} \\
& \mathrm{OA}_{\mathrm{k}}^{\mathrm{L}}=\frac{\mathrm{c}_{\mathrm{k}, \mathrm{k}}}{\min \left(\sum_{\mathrm{i}=1}^{\mathrm{n}} \mathrm{p}_{\mathrm{i}, \mathrm{k}}^{\mathrm{A}}, \sum_{\mathrm{i}=1}^{\mathrm{n}} \mathrm{p}_{\mathrm{i}, \mathrm{k}}^{\mathrm{B}}\right)} \\
& \mathrm{OA}_{\mathrm{k}}^{\mathrm{Q}}=\frac{\min \left(\sum_{\mathrm{i}=1}^{\mathrm{n}} \mathrm{p}_{\mathrm{i}, \mathrm{k}}^{\mathrm{A}}, \sum_{\mathrm{i}=1}^{\mathrm{n}} \mathrm{p}_{\mathrm{i}, \mathrm{k}}^{\mathrm{B}}\right)}{\max \left(\sum_{\mathrm{i}=1}^{\mathrm{n}} \mathrm{p}_{\mathrm{i}, \mathrm{k}}^{\mathrm{A}}, \sum_{\mathrm{i}=1}^{\mathrm{n}} \mathrm{p}_{\mathrm{i}, \mathrm{k}}^{\mathrm{B}}\right)}
\end{aligned}
$$

Equation 5.16

The confusion matrix cannot be directly interpreted as a change or error matrix. That is because element $c_{a, b}$ in the matrix indicates to what extent an abundance of category $a$ in map A overlaps with abundance of category $b$ in map B. This does not necessarily mean that $a$ in map $\mathrm{A}$ is replaced by $b$ in map $\mathrm{B}$, instead it can also mean that category $b$ is generally found in the neighbourhood of $a$. This is illustrated by the fact that the confusion matrix $C$ of two identical maps still contains off-diagonal elements. 
To resolve the ambiguity of the confusion matrix $C$, a second matrix $T$ is introduced. This matrix details how the decrease in one category co-occurs with the increase of another. It thus describes the nature of the transitions and can be interpreted as a change or error matrix. Non-zero values in the matrix indicate that within neighbourhoods, decrease of the row-category occurs together with increase by the column-category.

$$
\begin{aligned}
\mathrm{T} & =\left[\begin{array}{cccc}
\mathrm{t}_{1,1} & \mathrm{t}_{1,2} & \cdots & \mathrm{t}_{1, \mathrm{y}} \\
\mathrm{t}_{2,1} & \mathrm{t}_{2,2} & \cdots & \mathrm{t}_{2, \mathrm{y}} \\
\vdots & \vdots & \ddots & \vdots \\
\mathrm{t}_{\mathrm{y}, 1} & \mathrm{t}_{\mathrm{y}, 2} & \cdots & \mathrm{t}_{\mathrm{y}, \mathrm{y}}
\end{array}\right] \\
\mathrm{t}_{\mathrm{a}, \mathrm{b}} & =\sum_{\mathrm{i}=1}^{\mathrm{n}} \max \left(0, \min \left(\mathrm{p}_{\mathrm{i}, \mathrm{a}}^{\mathrm{A}}-\mathrm{p}_{\mathrm{i}, \mathrm{a}}^{\mathrm{B}}, \mathrm{p}_{\mathrm{i}, \mathrm{b}}^{\mathrm{B}}-\mathrm{p}_{\mathrm{i}, \mathrm{b}}^{\mathrm{A}}\right)\right)
\end{aligned}
$$

Equation 5.17

Note that the diagonal elements of matrix $\mathrm{T}$ are 0 by definition and therefore have no particular meaning.

The idea of separately addressing overlap and change can also be found in Lewis \& Brown (2001), who define separate confusion and error matrices. Their approach is aimed at soft classifications that are sum normal which means that it can be applied on regular abundance vectors but not fuzzy abundance vectors. The transition matrix introduced here can be applied on both.

\subsubsection{Neighbourhood similarity of configuration}

Landscape metrics of configuration summarize structure in terms of the spatial arrangement of categories over the map. The building blocks for many configuration metrics are patches. Patches are formed by groups of contiguous cells that are taken in by the same category. Patches are characterized, for instance, by their size and perimeter. Configuration metrics are common in landscape ecology (McGarigal et al. 2002) and they are sporadically used as performance criteria of a Cellular Automata model of urban dynamics (Power et al. 2001; Barredo \& Demicheli 2003) apply such metrics for the evaluation of a Cellular Automata model of urban dynamics.

The following patch characteristics have been applied: patch size, patch perimeter, fractal dimension and shape index. They are calculated according to the Fragstats documentation (McGarigal et al. 2002) and diagonally adjacent cells are considered contiguous as well (i.e. Queen contiguity is applied). The calculation of the perimeter includes 'holes' in patches as well as the edge of the map. The fractal dimension and the shape index are calculated according to Equation 5.18 and Equation 5.19. 
Both fractal dimension and shape index are measures to summarize the complexity of the spatial structure by relating the the area of patches to their perimeter.

$$
\begin{aligned}
& \mathrm{Sh}_{\mathrm{k}}=\frac{\mathrm{Pe}_{\mathrm{k}}}{4 \sqrt{\mathrm{Si}_{\mathrm{k}}}} \\
& \mathrm{Fr}_{\mathrm{k}}=\frac{2 \log \left(\mathrm{Pe}_{\mathrm{k}} / 4\right)}{\log \left(\mathrm{Si}_{\mathrm{k}}\right)}
\end{aligned}
$$

where:

$\mathrm{Si}_{\mathrm{k}} \quad$ size of the patch $k$ expressed in cell units

$\mathrm{Pe}_{\mathrm{k}} \quad$ perimeter of the patch $k$ in cell units

$\mathrm{Sh}_{\mathrm{k}} \quad$ shape index of a patch $k$

$\mathrm{Fr}_{\mathrm{k}} \quad$ fractal dimension of a patch $k$

Note that the fractal dimension must be calculated in cell units and not in real units as documented in McGarigal et al. (2002). Real units give undesired outcomes outside the range [1,2].

All configuration measures applied in this chapter are patch based. Since this means that structure is defined at a patch level, rather than a cell level, moving windows based aggregation becomes problematic. As a solution, intermediate metric maps are introduced. In these metric maps every cell has the value corresponding to the characteristic of the patch that it belongs to (Equation 5.20 and likewise for $\mathrm{Si}, \mathrm{Pe}$ and $\mathrm{Sh}$ ).

$$
\mathrm{M}_{\mathrm{i}}^{\mathrm{Fr}}=\mathrm{Fr}_{\mathrm{k}_{\mathrm{i}}}
$$

Equation 5.20

where:

$\mathrm{M}_{\mathrm{i}}^{\mathrm{Fr}} \quad$ value of cell $\mathrm{i}$ in the fractal dimension metric map

$\mathrm{k}_{\mathrm{i}} \quad$ index of the patch that contains cell $\mathrm{i}$

In the next step the metric maps are converted into moving averages by calculating for every cell the weighted average of its neighbourhood (Equation 5.21). Finally, the two moving average maps are compared by evaluating their difference cell-by-cell (Equation 5.22). The resulting map gives a spatial account of the difference in structure. 


$$
\begin{aligned}
& L_{i}^{\mathrm{Fr}, \mathrm{M}}=\frac{\sum_{\mathrm{j}=1}^{\mathrm{t}_{\mathrm{i}}} \mathrm{w}_{\mathrm{i}, \mathrm{j}} * \mathrm{v}\left(\mathrm{M}^{\mathrm{Fr}}, \mathrm{nbh}_{\mathrm{i}, \mathrm{j}}\right)}{\sum_{\mathrm{j}=1}^{\mathrm{t}_{\mathrm{i}}} \mathrm{w}_{\mathrm{i}, \mathrm{j}}} \\
& \mathrm{D}_{\mathrm{i}}^{\mathrm{Fr}}=\mathrm{L}_{\mathrm{i}}^{\mathrm{Fr}, \mathrm{B}}-\mathrm{L}_{\mathrm{i}}^{\mathrm{Fr}, \mathrm{A}}
\end{aligned}
$$

Equation 5.22

where:

$L_{i}^{F r, M} \quad$ neighbourhood fractal dimension at cell i of map M

$v(M, c) \quad$ function that reads the value of map $\mathrm{M}$ at cell $\mathrm{c}$

$n b h_{i, j} \quad$ the $\mathrm{j}$-th cell in the neighbourhood of cell $\mathrm{i}$

$w_{i, j} \quad$ the weight corresponding to the $\mathrm{j}$-th neighbour of $\mathrm{i}$

$t_{i} \quad$ the number of neighbours of cell $\mathrm{i}$

$D_{i}^{F r} \quad$ difference in fractal dimension at cell i

\subsection{Data}

\subsubsection{Virtual Workshop}

The methods have been applied on two data sets, D1 and D2, each consisting of a single pair of maps. The data sets were made available as part of the Geoide Virtual Workshop on map comparison (Boots \& Csillag 2007) and came without much background information.

Data set D1 came with the following information: "the first pair is trying to resemble a comparison between two labelling processes (same area, same date)". The maps are shown in figure 5.3.

The second dataset came with the following information: "the second pair is trying to resemble a comparison between maps from two consecutive time-steps of the same area and same labelling process". These maps are shown in figure 5.4.

\subsubsection{Preprocessing of data set D1}

The first impression from a visual inspection of maps D1a and D1b is that the definition of their legend categories is similar but not the same. In order to obtain consistent legends, the maps will be reclassified. The reclassification is based upon the degree to which categories in the two maps are confounded with each other. This can be expressed by the fuzzy confusion table $C_{\text {binaghi }}$ (table 5.1). Note that total abundance for a category is smaller than the sum of shared abundance over all categories in the other map. This is intentional and is born of the fact that shared abundance is non-exclusive (as it is based on the fuzzy 
intersection), thus a certain degree of abundance can overlap simultaneously with several categories.

Table 5.1 Fuzzy confusion matrix (*1000, Fuzzy weighted, $\alpha=2)$

\begin{tabular}{lllllll}
\hline D1a $\backslash$ D1b & cat 0 & cat 1 & cat 2 & cat 3 & cat 4 & $\begin{array}{l}\text { Total } \\
\text { abundance }\end{array}$ \\
\hline cat0 & 6.6 & 2.4 & 7.0 & 5.0 & 14.3 & 16.5 \\
cat1 & 2.0 & 5.5 & 5.3 & 2.9 & 4.4 & 7.8 \\
cat2 & 5.2 & 4.7 & 21.3 & 15.7 & 17.2 & 30.1 \\
cat3 & 2.4 & 1.7 & 10.2 & 22.3 & 23.9 & 32.1 \\
cat4 & 1.7 & 1.1 & 7.0 & 12.7 & 18.4 & 19.9 \\
cat5 & 3.5 & 1.7 & 8.0 & 11.4 & 35.4 & 35.8 \\
cat6 & 1.6 & 0.9 & 5.4 & 10.2 & 22.0 & 22.3 \\
Total & & & & & & \\
abundance & 6.6 & 5.5 & 21.5 & 24.1 & 46.3 & \\
\hline
\end{tabular}

Based upon the row and column totals of the matrix it is possible to calculate the prevalence according to Equation 5.23. This prevalence expresses the degree to which a category $a$ in map $A$ overlaps with a category $a$ in the map $B$. It is calculated as the product of the relative degree of overlap for both map $A$ and map $B$.

$$
\mathrm{p}_{\mathrm{a}, \mathrm{b}}^{\mathrm{AB}}=\frac{\mathrm{c}_{\mathrm{a}, \mathrm{b}}}{\mathrm{c}_{+, \mathrm{b}}} \frac{\mathrm{c}_{\mathrm{a}, \mathrm{b}}}{\mathrm{c}_{\mathrm{a},+}}
$$

where:

$\mathrm{c}_{\mathrm{a},+} \quad$ indicates the total abundance of category $a$ in map $A$

$\mathrm{c}_{+, \mathrm{b}} \quad$ indicates the total abundance of category $b$ in map $B$.

The results are given in table 5.2 and suggest that cat 4 in map D1b encompasses cat 4 , cat5 and cat6 in map D1a. The reclassified maps as depicted in figure 5.5 will be the topic of further evaluation. 


\section{Chapter 5}

Table 5.2 Prevalence, the strongest overlap for each category is highlighted

\begin{tabular}{llllll}
\hline $\mathrm{D} 1 \mathrm{a} \backslash \mathrm{D} 1 \mathrm{~b}$ & cat0 & cat1 & cat2 & cat3 & cat4 \\
\hline cat0 & 0.40 & 0.06 & 0.14 & 0.06 & 0.27 \\
cat1 & 0.08 & 0.70 & 0.17 & 0.04 & 0.05 \\
cat2 & 0.14 & 0.13 & 0.70 & 0.34 & 0.21 \\
cat3 & 0.03 & 0.02 & 0.15 & 0.64 & 0.38 \\
cat4 & 0.02 & 0.01 & 0.11 & 0.33 & 0.37 \\
cat5 & 0.05 & 0.01 & 0.08 & 0.15 & 0.75 \\
cat6 & 0.04 & 0.06 & 0.14 & 0.06 & 0.27 \\
\hline
\end{tabular}
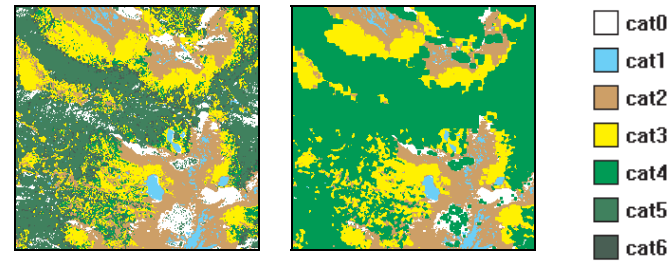
a. D1a
b. D1b

Figure 5.3 Data set D1. The maps contain 7 different classes.

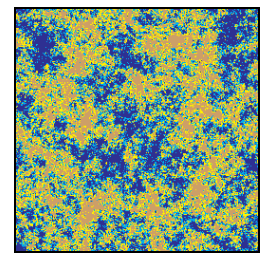

a. D2a

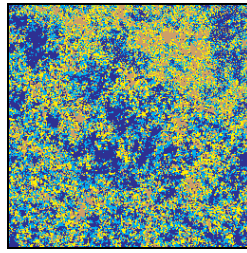

b. D2b

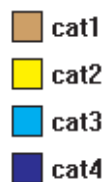

Figure 5.4 Data set D2.
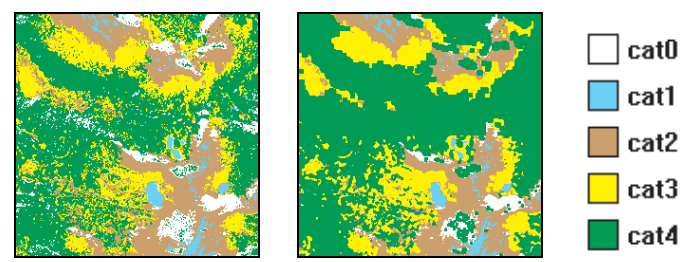

a. D1a reclass

b. D1b reclass

Figure 5.5 Reclassified maps of data set D1. 


\subsection{Results}

\subsubsection{Comparison results of data set D1 (Reclassified)}

The spatial distribution of fuzzy similarity (figure 5.6) and Euclidean distance (figure 5.7) is largely the same. Both local similarity measures indicate that the differences in the top half of the map are stronger than those in the bottom half. An essential difference also appears; in the fuzzy similarity map differences are sharply delineated, whereas in the Euclidean distance map the results are more blurry. This means that the fuzzy similarity map has the advantage that area and severity of disagreement can be assessed separately. In the Euclidean distance map on the other hand these are confounded and it is therefore not always possible to distinguish small areas of large disagreement from large areas of small disagreement. Compared to the simple binary cell-by-cell comparison that both methods derive from, the fuzzy similarity map has only gained information, since it not only tells which cells disagree but also to what extent. The Euclidean distance map has gained nuance, but at the cost of knowing the precise location of the disagreeing cells.

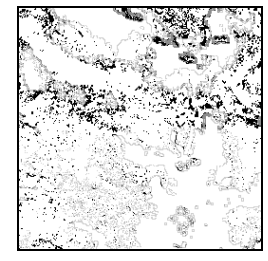

a. $\alpha=2$

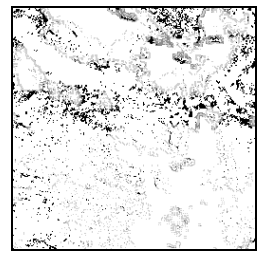

b. $\alpha=3$

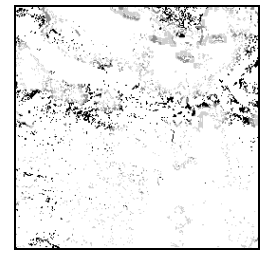

c. $\alpha=5$ $\square 0.75 \ldots 1.00$

$0.50 \ldots .75$

$\square 0.25 \ldots .0 .50$

$0.00 \ldots .25$

Figure 5.6 Fuzzy similarity, for dataset D1.

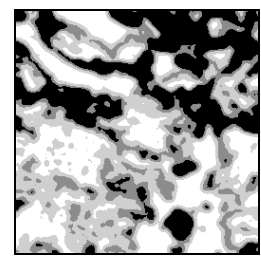

a. $\alpha=2$

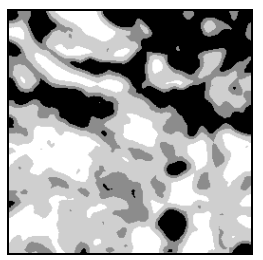

b. $\alpha=3$

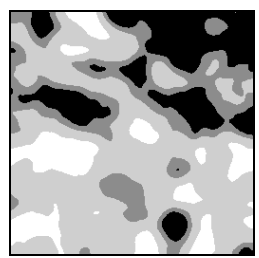

c. $\alpha=5$

Figure 5.7 Euclidean, for dataset D1 (weighted abundance).

Differences in quantity will, for an individual category of the legend, lead to an overall over- or underrepresentation in one map relative to the other. Differences in location on the other hand will lead to a mix of overrepresentation at some locations and underrepresentation at others. Considering this, the fuzzy similarity maps for individual categories (figure 5.8) are consistent with the $O A_{Q}$ and $O A_{L}$ statistics (table 5.3). The patterns of categories present in one map and not the other of figure 5.8 can be well matched, and all results indicate that the dominant transitions are those from 


\section{Chapter 5}

cat0 and cat3 in map D1a to cat4 in map D1b. Also considerable, but to a lesser extent there are shifts from cat 2 to cat 3 and cat 4 . This general pattern is confirmed and further quantified by the transition tables (table 5.4).

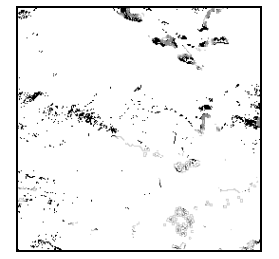

a. Cat0 in A not B

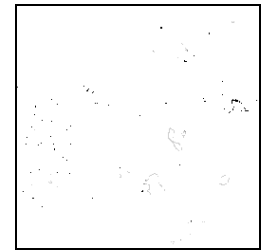

c. Cat1 in A not B

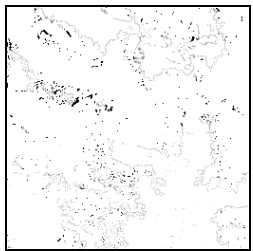

e. Cat2 in A not B

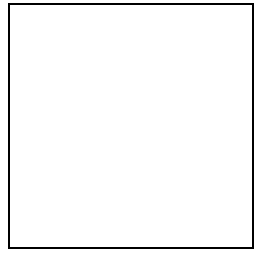

b. Cat0 in B not A
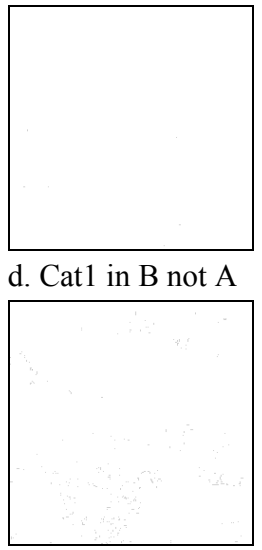

f. Cat2 in B not A
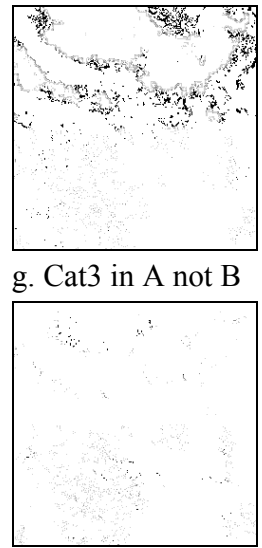

i. Cat4 in A not B

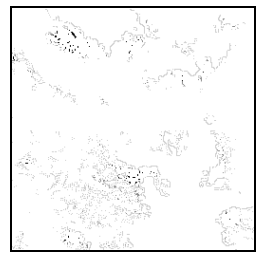

h. Cat3 in B not A

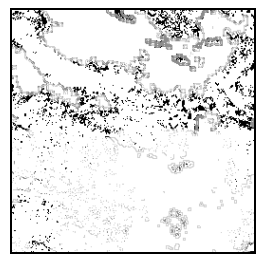

j. Cat 4 in $B$ not $A$

Figure 5.8 Per category similarity maps for omission and commission, $\alpha=2$ (same legend as figure 5.6).

The per category fuzzy similarity maps make plain that the differences relating to cat2 are mainly minor ones. Together with the results discussed above this suggests that the labelling process applied for map D1a places the border between cat 2 and cat 4 more towards cat 4 than the one for map D1b. Similarly it appears that the border between cat 3 and cat 4 is more towards cat 4 and the border between cat 2 and cat 3 towards cat 3 . These shifting boundaries form a larger distortion for the border between cat 3 and cat 4 than for the others. The differences related to cat 0 and cat 1 are for a large part strong differences. For cat 1 this is related to speckles of cat 1 that are present in map D1a but not D1b. Cat0 manifests large patches of strong differences, where it has a large presence $\mathrm{D} 1 \mathrm{a}$ but is not found close-by in D1b. It is for this reason that cat 0 is considered the most dissimilar (table 5.3, Fuzzy Kappa and $O A^{L Q}$ ) 
Table 5.3 Overall similarity and per category similarity for different metrics and settings. The category of lowest agreement is highlighted for every metric.

\begin{tabular}{lllllllll}
\hline Metric & Abundance & $\alpha$ & cat0 & cat1 & cat2 & cat3 & cat4 & Total \\
\hline $\mathrm{OA}^{\mathrm{LQ}}$ & Crisp & 2 & 0.348 & 0.855 & 0.768 & 0.747 & 0.767 & 0.831 \\
$\mathrm{OA}^{\mathrm{LQ}}$ & Crisp & 3 & 0.349 & 0.855 & 0.769 & 0.760 & 0.770 & 0.836 \\
$\mathrm{OA}^{\mathrm{LQ}}$ & Crisp & 5 & 0.351 & 0.854 & 0.769 & 0.776 & 0.773 & 0.842 \\
\hline $\mathrm{OA}^{\mathrm{L}}$ & Crisp & 2 & 1.000 & 0.999 & 0.999 & 0.827 & 0.988 & 0.954 \\
$\mathrm{OA}^{\mathrm{L}}$ & Crisp & 3 & 1.000 & 1.000 & 1.000 & 0.841 & 0.992 & 0.959 \\
$\mathrm{OA}^{\mathrm{L}}$ & Crisp & 5 & 1.000 & 1.000 & 1.000 & 0.859 & 0.996 & 0.965 \\
\hline $\mathrm{OA}^{\mathrm{Q}}$ & Crisp & 2 & 0.348 & 0.856 & 0.769 & 0.903 & 0.776 & 0.871 \\
$\mathrm{OA}^{\mathrm{Q}}$ & Crisp & 3 & 0.349 & 0.855 & 0.769 & 0.903 & 0.776 & 0.871 \\
$\mathrm{OA}^{\mathrm{Q}}$ & Crisp & 5 & 0.351 & 0.854 & 0.769 & 0.904 & 0.777 & 0.872 \\
\hline $\mathrm{OA}^{\mathrm{LQ}}$ & Fuzzy & 2 & 0.398 & 0.704 & 0.707 & 0.694 & 0.896 & 0.748 \\
$\mathrm{OA}^{\mathrm{LQ}}$ & Fuzzy & 3 & 0.423 & 0.674 & 0.721 & 0.726 & 0.921 & 0.750 \\
$\mathrm{OA}^{\mathrm{LQ}}$ & Fuzzy & 5 & 0.467 & 0.658 & 0.757 & 0.778 & 0.947 & 0.765 \\
\hline $\mathrm{OA}^{\mathrm{L}}$ & Fuzzy & 2 & 1.000 & 0.995 & 0.990 & 0.926 & 0.957 & 0.962 \\
$\mathrm{OA}^{\mathrm{L}}$ & Fuzzy & 3 & 1.000 & 0.997 & 0.994 & 0.950 & 0.960 & 0.970 \\
$\mathrm{OA}^{\mathrm{L}}$ & Fuzzy & 5 & 1.000 & 0.998 & 0.996 & 0.970 & 0.967 & 0.980 \\
\hline $\mathrm{OA}^{\mathrm{Q}}$ & Fuzzy & 2 & 0.398 & 0.708 & 0.714 & 0.750 & 0.936 & 0.778 \\
$\mathrm{OA}^{\mathrm{Q}}$ & Fuzzy & 3 & 0.423 & 0.676 & 0.726 & 0.765 & 0.959 & 0.773 \\
$\mathrm{OA}^{\mathrm{Q}}$ & Fuzzy & 5 & 0.467 & 0.659 & 0.760 & 0.802 & 0.980 & 0.781 \\
\hline Fuzzy Kappa & Fuzzy & 2 & 0.363 & 0.922 & 0.757 & 0.441 & 0.392 & 0.539 \\
Fuzzy Kappa & Fuzzy & 3 & 0.275 & 0.914 & 0.738 & 0.371 & 0.291 & 0.478 \\
Fuzzy Kappa & Fuzzy & 5 & 0.116 & 0.895 & 0.710 & 0.272 & 0.154 & 0.385 \\
\hline
\end{tabular}

As the scale of the analysis increases (halving distance becomes larger) the intuitively expected response would be that agreement related to quantity remains constant and furthermore that the agreement due to location increases. The results follow this intuition for the regular weighted abundance (abundance according to Equation 5.6) but not for the fuzzy weighted abundance (abundance according to Equation 5.7). The crux is that (total) fuzzy weighted abundance increases with halving distance, whereas (total) crisp weighted abundance remains the same. The effect on total quantity of different categories will not be uniform; as the abundance of each category depends on the nearest neighbour distance for that category therefore the total abundance of categories that have a small or scattered presence on the map will be affected the strongest.

The reason that the agreement of quantity for the crisp weighted abundance is not fully independent of the halving distance is that at the edges of the map neighbourhood sizes are smaller and the relative impact of individual cells on the abundance of their neighbours will vary. 
Chapter 5

Table 5.4 Transition tables (fuzzy weighted abundance)

a. $\alpha=2$

\begin{tabular}{llllll}
\hline map $a \backslash$ map b & cat0 & cat1 & cat2 & cat3 & cat4 \\
\hline cat0 & -- & 23.12 & 96.97 & 396.46 & 2018.51 \\
cat1 & 0.00 & -- & 34.26 & 181.90 & 448.38 \\
cat2 & 0.00 & 11.28 & -- & 970.37 & 2052.25 \\
cat3 & 0.00 & 3.08 & 71.52 & -- & 1998.13 \\
cat4 & 0.00 & 0.85 & 68.31 & 604.81 & -- \\
\hline b. $\alpha=3$ & & & & & \\
\hline map a $\backslash$ map b & cat0 & cat1 & cat2 & cat3 & cat4 \\
\hline cat0 & -- & 23.64 & 95.98 & 462.34 & 1852.95 \\
cat1 & 0.00 & -- & 37.94 & 215.31 & 608.83 \\
cat2 & 0.00 & 12.40 & -- & 738.32 & 1803.43 \\
cat3 & 0.00 & 3.28 & 55.38 & -- & 1563.24 \\
cat4 & 0.00 & 0.76 & 57.14 & 503.21 & -- \\
\hline c. $\alpha=5$ & & & & & \\
\hline map a $\backslash$ map b & cat0 & cat1 & cat2 & cat3 & cat4 \\
\hline cat0 & -- & 20.91 & 82.98 & 465.77 & 1517.55 \\
cat1 & 0.00 & -- & 37.96 & 240.35 & 765.05 \\
cat2 & 0.00 & 12.16 & -- & 496.44 & 1325.58 \\
cat3 & 0.00 & 2.87 & 39.22 & -- & 1072.42 \\
cat4 & 0.00 & 0.57 & 41.69 & 367.21 & -- \\
\hline
\end{tabular}

The comparison maps of spatial structure are given in the maps of figure 5.9. Note that the interpretation of the legend here is different from the earlier similarity maps. Dark colours indicate an increase (of e.g. patch size) and light colours a decrease in map D1a relative to D1b. Thus, cells of identical structure are not white but grey instead.

Map D1a is contains finer details than map D1b. As a result the moving average of patch size is overall larger in map D1b, the perimeter of patches is larger as well. The complexity of the shapes, measured either by shape index or fractal dimension is strongly influenced by the large patch of cat 4 that occupies the major part of both maps. The largest impacts on patch size and fractal dimension are found in the upper part of the map and can be explained by one large patch of cat2 in map D1a that is broken into several smaller patches of the same category in map D1b. 


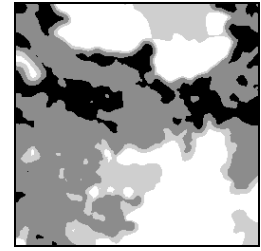

a. Patch size, $\alpha=2$

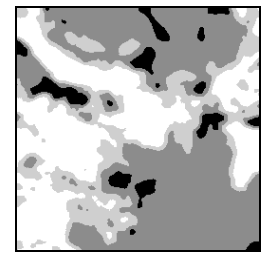

d. Perimeter, $\alpha=2$

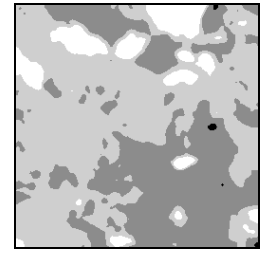

g. Fractal dimension, $\alpha$ $=2$

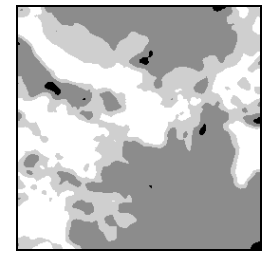

j. Shape index, $\alpha=2$

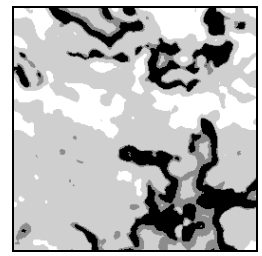

$\mathrm{m}$. Shannon diversity, $\alpha=2$

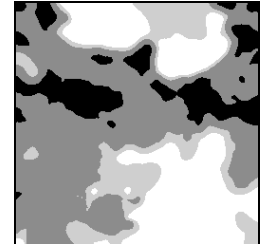

b. Patch size, $\alpha=3$
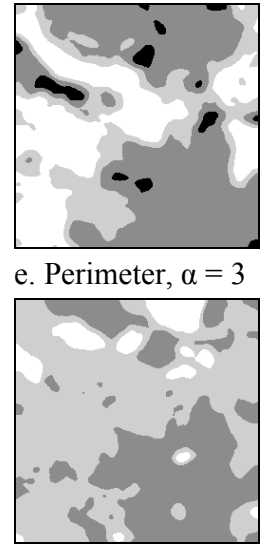

h. Fractal dimension, $\alpha$ $=3$

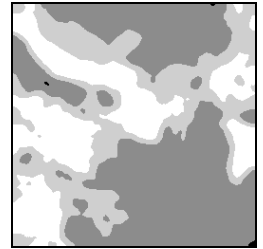

k. Shape index, $\alpha=3$

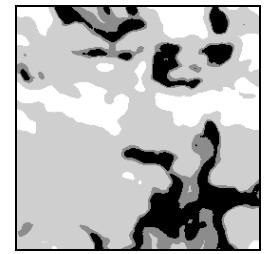

n. Shannon diversity, $\alpha=3$

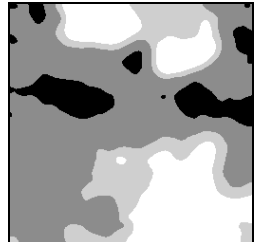

c. Patch size, $\alpha=5$

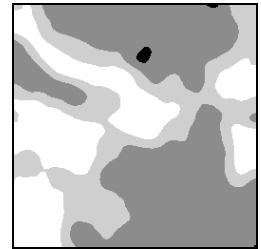

$-8200 \ldots-5300$

$-5300 \ldots-2500$

$-2500 \ldots 0$

0 ... 3750

f. Perimeter, $\alpha=5$

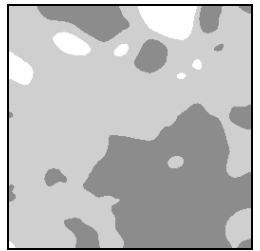

$-0.50 \ldots-0.25$

$-0.25 \ldots-0.17$

$-0.17 \ldots 0.00$

$0.00 \ldots .04$

i. Fractal dimension, $\alpha$ $=5$

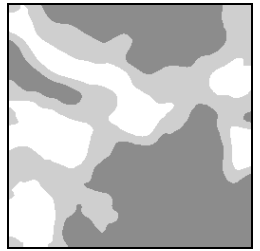

$\square-14 \ldots-10$

$\square-10 \ldots-6$

$\square-6 \ldots 0$

$0 \ldots 3$

1. Shape index, $\alpha=5$

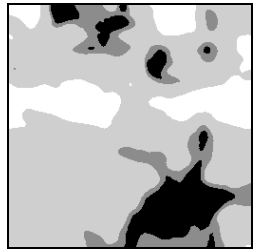

$-1.22 \ldots-0.48$

$-0.48 \ldots .00$

$0.00 \ldots .07$

$0.07 \ldots .60$

o. Shannon diversity, $\alpha=5$

Figure 5.9 Comparison on structure for data set D1. (positive values indicate larger values in Dlb relative to Dla)

\subsubsection{Comparison results of data set D2}

Both the fuzzy similarity (figure 5.10) and the Euclidean distance map (figure 5.11) point out that the data set falls apart into two regions with clearly different dynamics. A line from the upper left corner of the maps to the middle of the right border separates the map in a static (little change) upper part and a 
dynamic (much change) lower part. Table 5.5 shows fuzzy kappa statistics calculated for the upper and the lower region and confirms the sharp contrast.

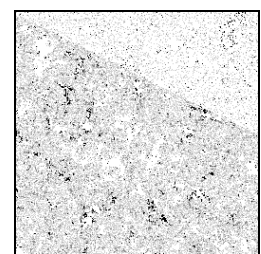

a. $\alpha=2$

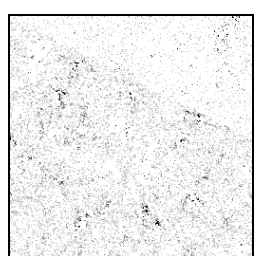

b. $\alpha=3$

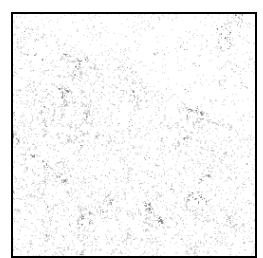

c. $\alpha=5$
$0.75 \ldots 1.00$
$0.50 \ldots 0.75$
$0.25 \ldots 0.50$
$0.00 \ldots 0.25$

Figure 5.10 Fuzzy similarity, for dataset D2.

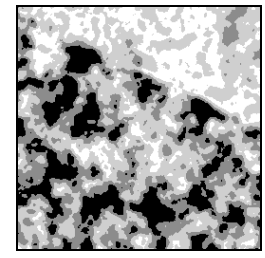

a. $\alpha=2$

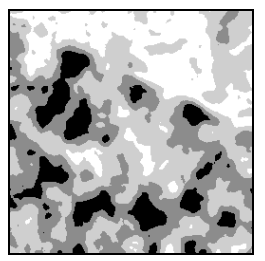

b. $\alpha=3$

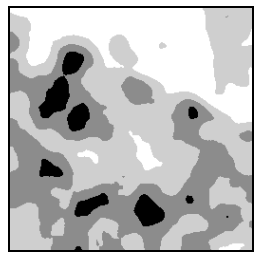

c. $\alpha=5$

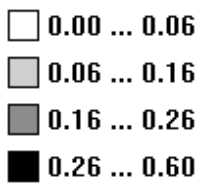

$0.26 \ldots .60$

Figure 5.11 Euclidean, for dataset D2 (weighted abundance)

Table 5.5 Fuzzy kappa similarity profiles for upper and lower region $(\alpha=2)$

\begin{tabular}{llllll}
\hline Region & cat1 & cat2 & cat3 & cat4 & Total \\
\hline Lower & 0.426 & 0.326 & 0.268 & 0.327 & 0.259 \\
Upper & 0.744 & 0.729 & 0.761 & 0.821 & 0.732 \\
\hline
\end{tabular}

The results (figure 5.12) of fuzzy similarity values for cat 2 and cat 3 indicate that the differences for these categories are the smallest. Their difference is mainly due to location, meaning that these categories expand a bit at some locations and contract at others. In general they do not appear in areas without an initial presence, or disappear complete from a neighbourhood. Stronger differences are found relating to cat1 (mainly disappearing), but the strongest differences are related to the appearing of cat 4 in map D1b; cat4 forms a new presence in areas where it was hardly present before.

The structure based comparisons (figure 5.13) uncover a second pattern of disagreement, beside the upper and lower region divide. Concentric circles are recognized that display distinct structural changes. The centre area of the map there is characterized by increasing patch size and patch perimeter and a decrease in diversity. The ring shows an inverse trend. The remainder of the map forms a less pronounce third ring where changes are more or less neutral.

It is striking that the spatial distributions of patch size and perimeter changes are practically identical. This is an indication that some structural characteristic of 
the patches is conserved. The results indicate however that this is neither fractal dimension nor shape index.

Further insight in the nature of the difference follows from a per category comparison on patch size (figure 5.14). Here the patterns underlying those of figure 5.13 are illuminated. The structural differences mainly follow from an increase in patch size of cat 4 in the centre of the map and a decrease in patch size of cat 1 in the ring surrounding it. Cat 2 and cat 3 behave more or less neutral (note that ranges of the legends in figure 5.14 vary considerably).

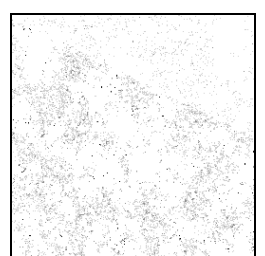

a. Cat1 in A not B

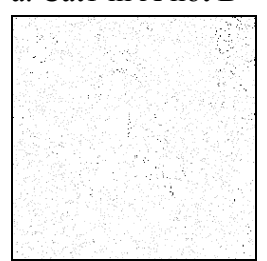

e. Cat1 in B not A

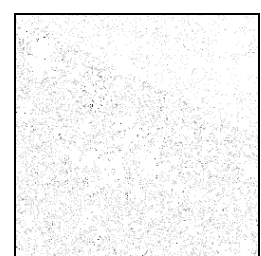

b. Cat2 in A not B

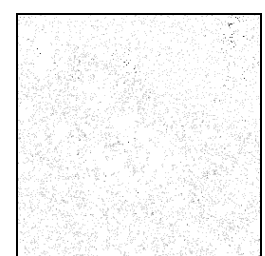

f. Cat2 in B not A

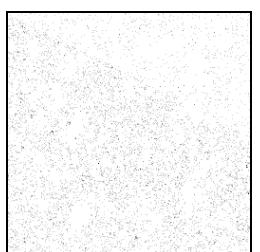

c. Cat3 in A not B

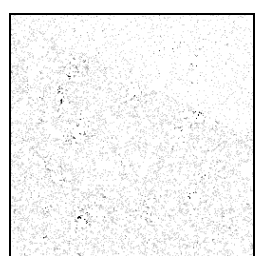

g. Cat3 in B not A

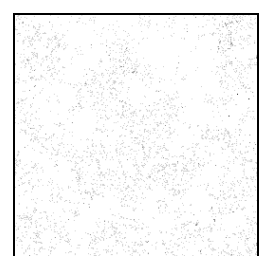

d. Cat4 in A not B

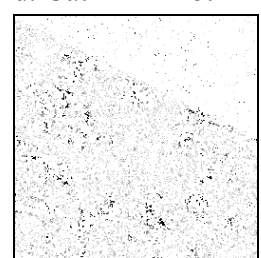

h. Cat4 in B not A

Figure 5.12 Per category similarity maps for increase and decrease, $\alpha=2$ (same legend as figure 5.10) 


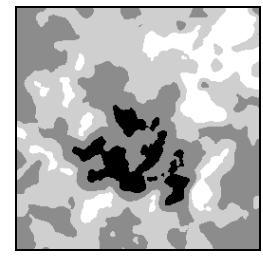

a. Patch size, $\alpha=2$

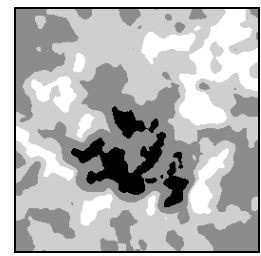

d. Perimeter, $\alpha=2$

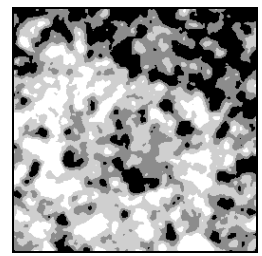

g. Fractal dimension, $\alpha$ $=2$

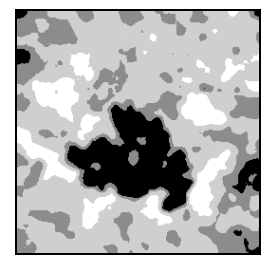

j. Shape index, $\alpha=2$

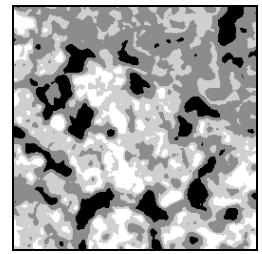

$\mathrm{m}$. Shannon diversity, $\alpha$ $=2$

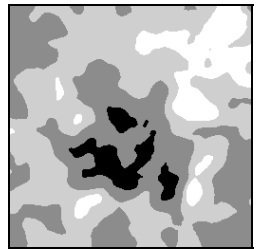

b. Patch size, $\alpha=3$

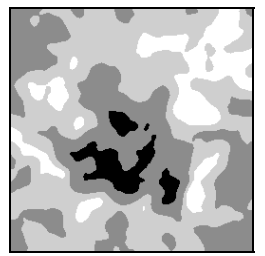

e. Perimeter, $\alpha=3$

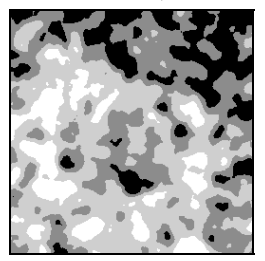

h. Fractal dimension, $\alpha$ $=3$

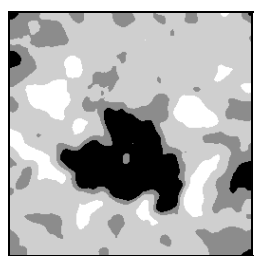

k. Shape index, $\alpha=3$

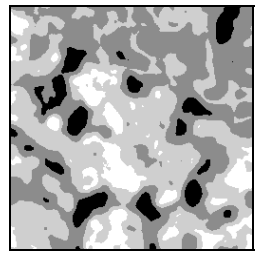

n. Shannon diversity, $\alpha$ $=3$

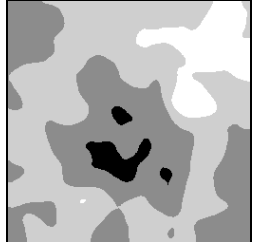

$-1700 \ldots-350$

$-350 \ldots 0$

0 ... 1600

$1600 \ldots 3200$

c. Patch size, $\alpha=5$

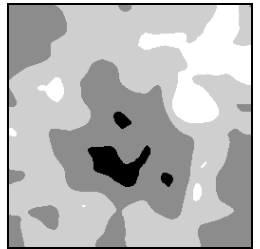

$-1700 \ldots-350$

$-350 \ldots 0$

0 ... 1600

$1600 \ldots 3200$

\section{f. Perimeter, $\alpha=5$}

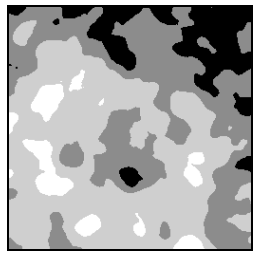

$-0.31 \ldots-0.11$

$-0.11 \ldots-0.05$

$-0.05 \ldots .00$

$0.00 \ldots .18$

i. Fractal dimension, $\alpha$ $=5$

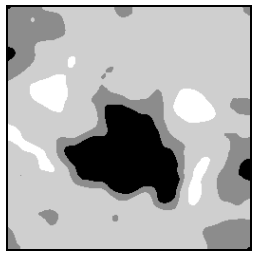

$-8.6 \ldots-2.3$

$-2.3 \ldots 0.0$

$0.0 \ldots 1.8$

$1.8 \ldots 9.7$

1. Shape index, $\alpha=5$

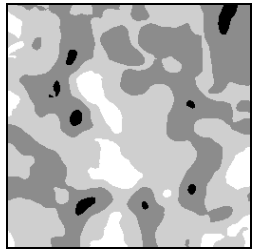

$-0.4 \ldots-0.1$

]-0.1 ... 0.0

$0.0 \ldots .2$

$0.2 \ldots 0.8$

o. Shannon diversity, $\alpha$ $=5$

Figure 5.13 Comparison on structure for data set D2 (positive values indicate larger values in D2b relative to D2a, thus an increase over time) 


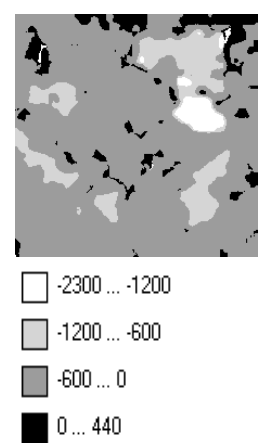

a. cat 1

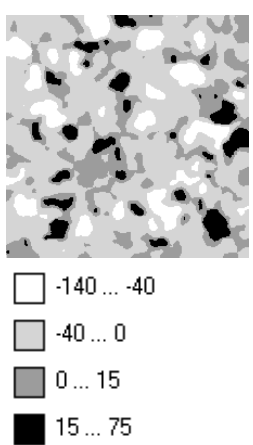

b. cat2

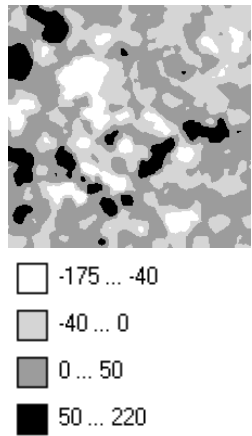

c. cat3

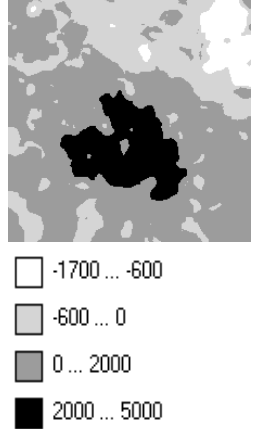

d. cat4

Figure 5.14 Comparison on patch size for individual categories $(\alpha=2)$.

\subsection{Discussion}

For dataset D1a emphasis has been on the severity of difference, by applying neighbourhood based methods the difference can be expressed in nuance. In particular the distinction between major and minor differences is made at the cellular level, which is not made by more common cell-by-cell methods.

The nature of the difference becomes clear from the fuzzy set map comparison methods for omission and commission that were introduced in chapter 4 . The new neighbourhood based Euclidean distance maps and transition tables confirm the results of the fuzzy set map comparison, but do not offer new insights.

Where neighbourhood based contingency and transition tables are used it appears (and is confirmed by Foody (2006) as part of the same Virtual Workshop on Map Comparion) that their original cell based counterparts have a less ambiguous interpretation and lead to the same conclusions.

The benefits of more nuance and accounting for proximity did not materialize in this experiment. This can be explained by the setup of the experiment, by only comparing two single map pairs with hardly any context the analysis lacks a reference level. The numerical results exist in a void, within which nuances are lost.

The results of dataset D2a demonstrated the merit of a neighbourhood based comparison of structure. The pattern of structural differences that emerges gives suggestions for further investigation towards the processes underlying the changes. The neighbourhood based approach is essential to find these results, because at the landscape level reverse trends at different locations would annihilate each other. The lack of a reference level is less problematic in this case, since by giving a spatial distribution of differences the methods supply their own reference material. Aggregated statistics of structural similarity (mean 


\section{Chapter 5}

squared error) were calculated as well, however these are not reported because again the lack of reference material prevents meaningful interpretation. Chapter 7 will present a framework to unite map comparison results of multiple criteria and introduce neutral models of landscape change that serve as the much needed reference level.

\subsection{Conclusion}

This chapter introduced neighbourhood variants of cell-by-cell and landscape level structure comparisons. This chapter recognizes these approaches as the extremes on a continuous scale for local to global comparisons. The intermediate level of comparisons, at the neighbourhood or focal level can combine characteristics of both approaches. In particular the advantage over cell-by-cell methods is that spatial relations and geographical structure become part of the comparison. On the other hand the advantage over landscape level comparison is that neighbourhood based comparisons recognize that structure is not a homogenous landscape characteristic but varies in space. The spatial covariation is explicitly considered in neighbourhood based comparisons of spatial structure.

The structure difference maps demonstrate the advantage of the neighbourhood based approaches. They provide extensive information on the extent and nature of agreement between the maps. Such information cannot be gained from landscape level analysis alone. For instance, all structure difference maps contain both positive and negative values, whereas at the landscape level either a gain or loss is registered.

An additional advantage, beyond the current application of map comparison, is that in neighbourhood based landscape analysis is the scale of the analysis is set by a (distance decay) parameter rather than the resolution of the data or the extent of the study area. This property is of most value when multiple scales are considered in a single study.

The further specification of similarity to individual categories was also applied in chapters 2 and 4. Again it provides further insight in the nature and distribution of agreement between maps.

The case material is characterized by a lack of context. As such there is little ground for attaching meaning to the metrics that present a single value. The benefit of these metrics over their cell-by-cell or landscape level counterparts remains unproven. This underlines the need of establishing reference levels. Chapter 6 will provide a methodology for creating reference maps and apply it on structure based similarity metrics. 


\section{Uniting comparisons over multiple criteria}

\subsection{Introduction}

The structure based map comparison methods presented in chapter 5 give rich information about the spatial distribution of structural differences. That chapter also demonstrates, however, that single figure similarity indices without a frame of reference are not open to a meaningful interpretation. Furthermore chapter 5 indicated that ranges at which similarity is expressed can vary strongly both depending on the metric itself and the scale at with it is applied. This chapter introduces a methodological framework that that aims to discern to what extent model performance, expressed by a variety of metrics, can be attributed to processes that are endogenous to the model or to exogenous model inputs.

For this purpose, neutral models of landscape change are introduced that are subject to the same boundary conditions and constraints as the probed model, but otherwise represent no specific processes except reluctance to change. The neutral models serve as benchmark and the difference in performance with the model under investigation can be attributed to the endogenous qualities of the model. Furthermore, the framework makes performance measures over multiple criteria and scales mutually comparable and helps identifying strengths and weaknesses of the model.

This chapter seeks to answer the following questions:

- How can diverse metrics of model goodness-of-fit be mutually compared to indicate strengths and weaknesses of the evaluated model?

- To what extent must goodness-of-fit be attributed to modeled processes or to boundary conditions and constraints?

The second question may seem more abstract, but in fact refers to a real and persistent problem; It is not uncommon for land use models to attain a percentage correct of about $95 \%$, but this 'very good performance' is then due to the fact that the landscape at the end of the simulation period is largely identical to the given initial situation. Another common constraint on land use models is the total area per land use class. This is applied when in fact the model is not intended to represent the change in area (quantity) of land use classes, but only the spatial distribution. The exogenously imposed areas per 


\section{Chapter 6}

land use class will influence model accuracy, regardless of the adequacy of the modeled processes. Chapter 2 and 3 (as well as Pontius et al. 2004) already addressed the impact of the initial situation, but not the impact of other constraints.

Neutral landscape models that are common in landscape ecological studies, may be useful to this problem. Neutral models are algorithms that create landscape patterns in absence of specific processes (With \& King 1997). Comparison of the performance of the investigated model to that of neutral models can help determining to what extent the model performance must be attributed to processes that are absent in the neutral model.

'Textbook' neutral landscape models (Turner et al. 2001 Ch. 6) are not appropriate as reference for dynamic models however. These models create a landscape starting from a blank or randomized initial situation and therefore can not account for the effect of the initial situation. A recent extension to neutral landscape models (Gardner \& Urban 2007) applies a mask to separate the landscape in static (not changing) and dynamic (changing) region. In that extension, however, the landscape in the dynamic region is still created from a blank initial situation and the model is therefore not adequate for the purpose of this paper either.

To resolve this shortcoming, this paper introduces a new class of neutral landscape models: neutral models of landscape change. These models do not create a landscape from a blank initial situation, but instead modify an existing initial landscape. These models are subject to the same boundary condition and constraints as the probed model and therefore pose an adequate reference level. Turner (1987) and Pontius et al. (2007) provide earlier applications of simple models of landscape change as benchmarks for more complex ones.

The evaluated model in the case study is the Constrained Cellular Automata (CCA) land use model calibrated for the island La Réunion. The comparison methods used within the framework combine the wavelet decomposition approach of Briggs \& Levine (1997) with the structure indicator maps of Chapter 5. This combination is particularly suited to test and demonstrate the methodological framework since it presents diverse indicators of model performance at multiple scales.

\subsection{Method}

\subsubsection{General procedure}

The performance of spatial models is assessed by running them for a period in the past and comparing the output of the model to reality. Model and reality are compared on a number of criteria that are evaluated at multiple scales. These diverse indicators of model performance are normalized to the real change that 
occurred over the simulation period, measured according to the same criteria. This means of normalization reflects the need to account for persistence already observed by Tobler (1970) and is inspired by recent findings of Pontius et al. (2008) that model performance correlates strongly with the amount of change over the simulation period.

The comparison is not just made for the evaluated model, but also for one or more neutral models of landscape change. These models are subject to the same boundary conditions and constraints as the evaluated model. Otherwise the neutral models are conservative, which means that they minimize change. What constitutes minimal change remains ambiguous, therefore multiple neutral models of landscape change may be applied. The model performance is expressed relative to that of the neutral models of landscape change.

Figure 6.1 presents a flowchart of the general procedure. The specific neutral models, performance criteria and means of normalization that are applied in this paper are given in the following sections.

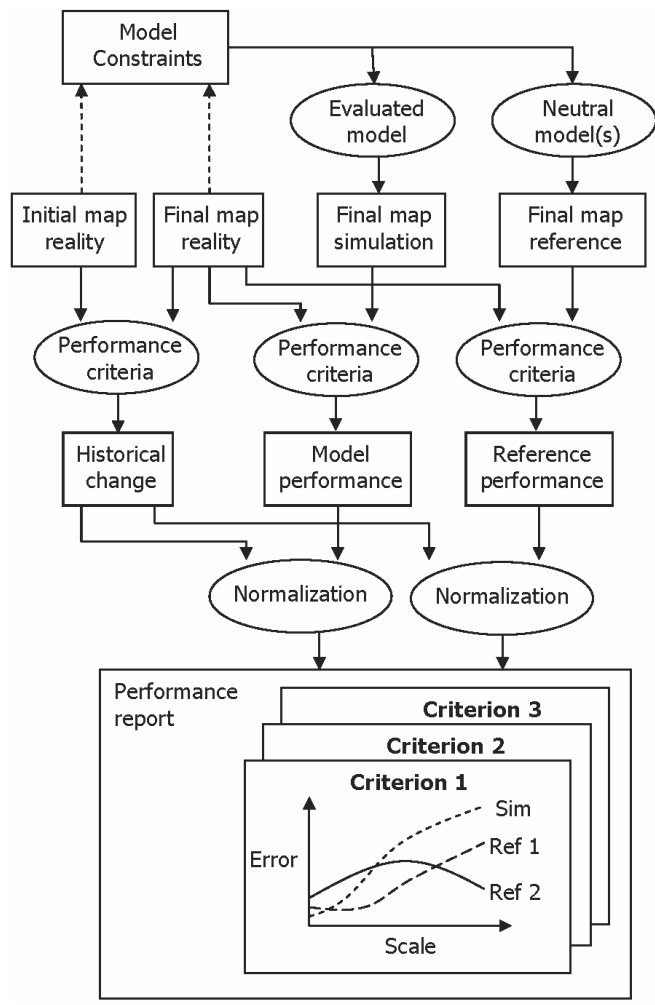

Figure 6.1 Flowchart of model performance evaluation. The dashed lines indicate that Model constraints are not necessarily based on the initial and final map of reality, but in the current case they are. 


\section{Chapter 6}

\subsubsection{Neutral models of landscape change}

This section introduces two neutral models of landscape change. Both neutral models modify the initial map to the effect that it has the same composition (total area per class) as the simulated map. This is the same constraint that is also applied in the evaluated model. Both neutral models follow the notion of changing as little as possible, the difference is that the random constraint match model places change at randomly selected locations, whereas the growing clusters model also places new cells of a class adjacent to existing cells of that class.

Pseudo code of both models is given in the two text boxes.

\section{Neutral model: Random constraint match}

The random constraint match model finds locations of change randomly and evolves towards a 'speckled' map of small clusters.

The model first assesses for each class how many cells it is under- or overrepresented in the initial map relative to the constraints. For each overrepresented class it then randomly selects the surplus cells on the initial map. Then, the underrepresented classes are randomly distributed over the selected cells on the initial map.

For example, consider a dataset of four land use classes (agriculture, urban, nature, water). Agriculture and nature become less prevalent over time, while water and urban are gaining. Initially there are 450 cells of agriculture whereas the constraint for the end situation is 410 , which means that the class agriculture is overrepresented by 40 cells. Out of the 450 cells of agriculture, 40 are selected to change class. Likewise, the class nature is overrepresented by 10 cells and out of the initial nature cells 10 are selected. In total 50 cells have been selected to change class. The class urban is underrepresented by 45 cells and the class water by 5 cells. Thus out of the 50 cells that will change class, 45 cells are randomly selected. These change to the class urban. The remaining 5 cells change to the class water. Now all constraints are satisfied.

Textbox 6.1 Pseudo-code Random Constraint Match

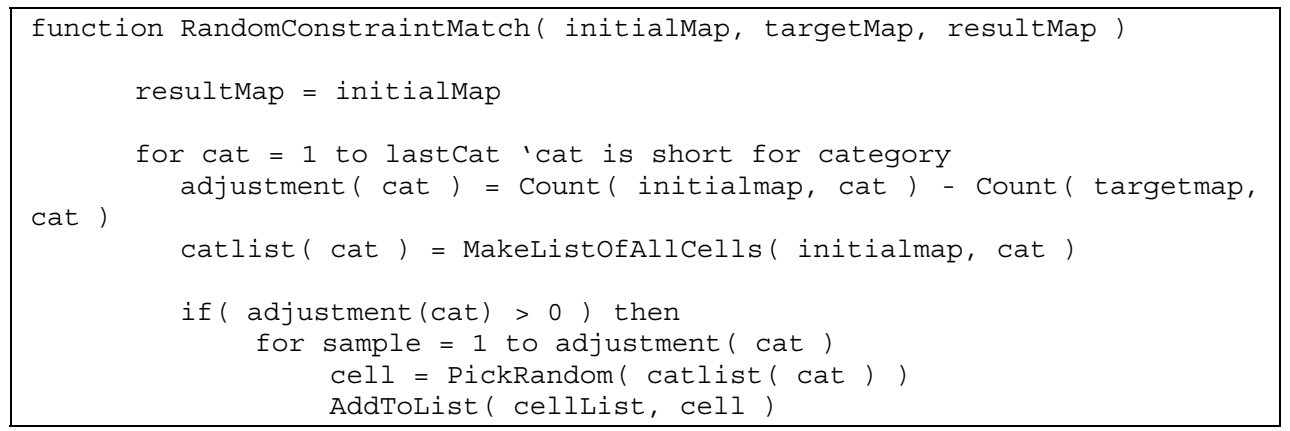




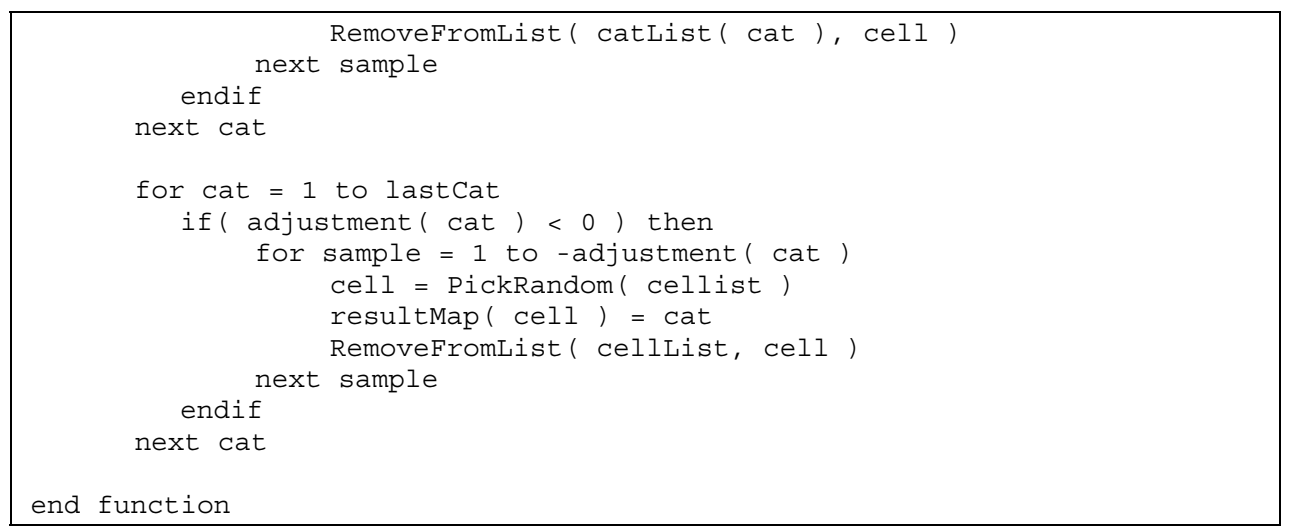

\section{Neutral model: Growing clusters}

The growing clusters model finds locations for changes along the edges of existing patches (clusters). This model evolves towards 'blobby' map of large patches.

The model first counts cells for all classes both in the initial map and in the target map. The model then compiles a list of all edges in the initial map where an underrepresented category borders an overrepresented category. Then, it repeatedly selects edges from this list and changes the cell with the overrepresented category to take the value of the underrepresented category. The transition will take place only if that cell has not changed yet and the categories along the edge are still overrepresented, respectively underrepresented.

It is possible that the list of edges is exhausted before all required changes are made. In that case the procedure is repeated with the adjusted map as the new initial map. Another possibility is that no more edges between over- and underrepresented classes are found. In that case, for each underrepresented class randomly a cell of an overrepresented class is found and the transition is made. The new random changes can be the seeds of growing clusters and the procedure is repeated until all constraints have been met.

Textbox 6.2 Pseudo-code Growing Clusters

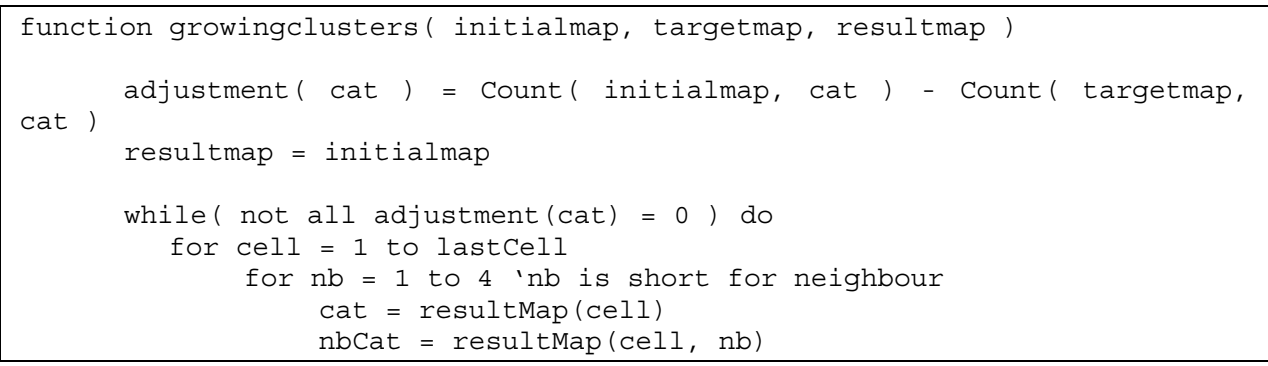




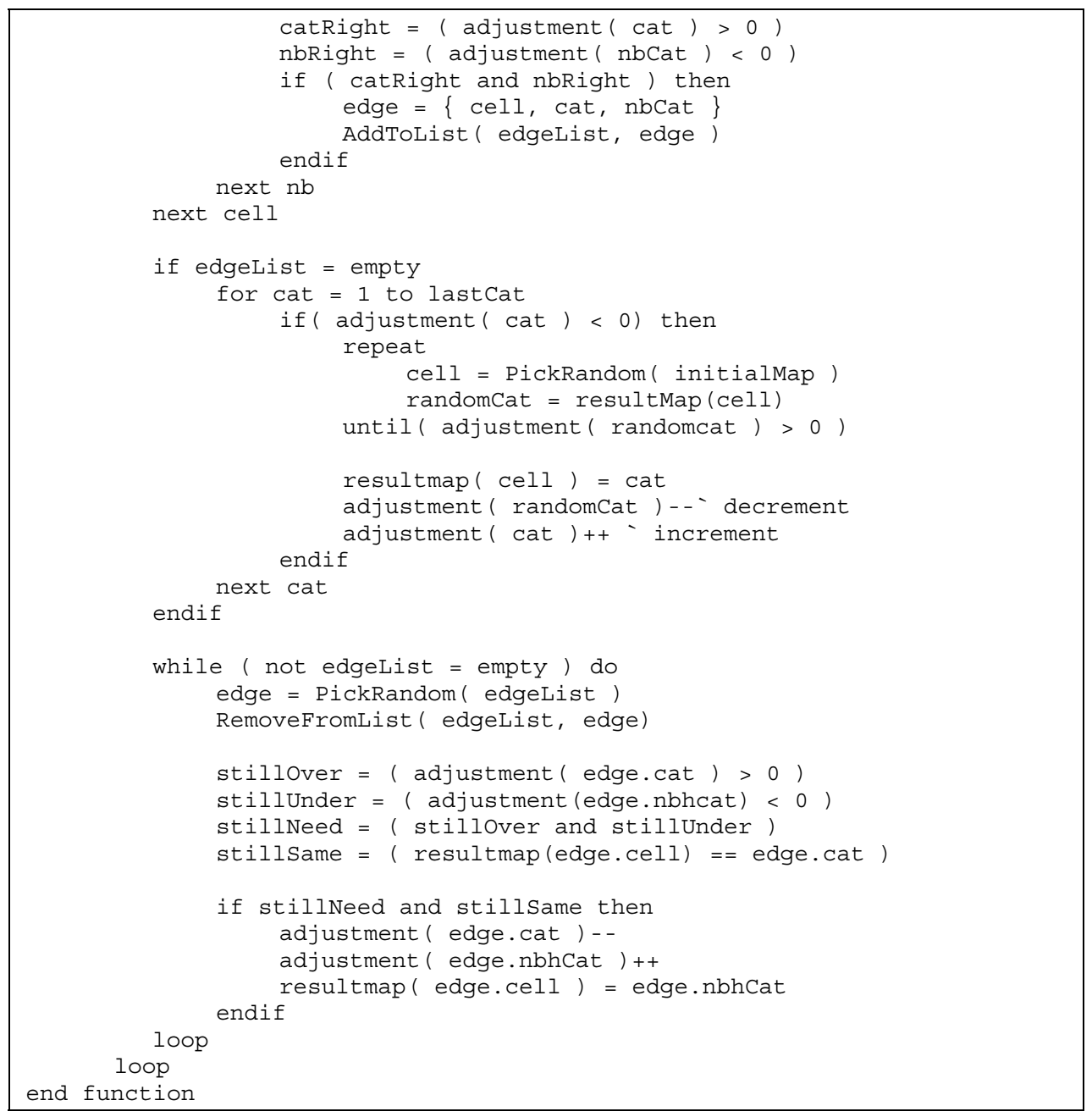

\subsubsection{Performance criteria}

Real and model maps are compared on several characteristics that are selected on the basis of the intended and perceived strengths of the evaluated model. The spatial interaction of the Constrained Cellular Automata land use model is in particular expected to represent the dynamic processes underlying urban morphology, therefore the performance is measured in terms of both structure and presence at multiple scales. With 'presence' is meant the extent to which occurrence of a class coincides in both maps. Likewise, with 'structure' is meant the extent to which indicators of spatial structure correspond in both maps.

The structure metrics that are applied are based on the patch size and patch fractal dimension metrics for individual land use classes. Urban patch size is 
included because we perceive it to be the main criterion in the visual assessment of map similarity for this kind of model. Urban fractal dimension is included because earlier model assessments put emphasis on the area to perimeter relation of urban clusters.

The class agriculture is evaluated only in terms of presence, because this class is modeled primarily on the basis of site characteristics and not spatial interaction. Multi-scale analysis is appropriate since the site characteristics have multi-scale features.

\section{Criterion maps}

The first step of the comparison derives criterion maps from the two compared land use maps for each of the criteria introduced above. The criterion maps for urban and agricultural presence have value 1 where the respective class is present and 0 elsewhere. Urban patch size and urban patch fractal dimension criterion maps give every cell the value of the patch that it belongs to, i.e. an urban cell belonging to a patch with size $s$, obtains value $s$.

The identification of patches is based on Queen Contiguity, i.e. diagonally adjacent cells are considered contiguous. Patch size is simply the number of cells in a patch. Patch fractal dimension (Equation 6.1) is based on the FRAGSTATS definition (McGarical et al. 2002), which means that 'fractal dimension' is a shape characteristic and not a fractal dimension in mathematical terms (Frankhauser 1994).

$$
\mathrm{F}=\frac{2 \log (\mathrm{p} / 4)}{\log (\mathrm{a})}
$$

Equation 6.1

where:

F fractal dimension of a patch

a area of the patch expressed in cell units

$\mathrm{p} \quad$ perimeter of the patch in cell units.

\section{Multi-scale analysis by wavelet transformation}

A wavelet transformation is used to decompose the criterion maps into criterion maps at multiple scales. The idea of the transformation is that large clusters of similar values are registered at coarse scales (large wavelengths) and small clusters of similar values at fine scales (small wavelengths). The transformation is quite different from block and moving window aggregation techniques that are more commonly used. In aggregation approaches coarse scale information remains present at finer scales implying that some errors are registered at multiple scales. This is not the case with wavelet transformation since it splits the data into layers at different scales by separation; information is not repeated 


\section{Chapter 6}

in the different layers. Another attractive property of the wavelet approach is that the squared difference between two transformed maps over all scales amounts to the difference of the original untransformed maps. Therefore it can be said that the wavelet approach decomposes the difference between maps into multiple scales.

Wavelet transformation is a technique that transforms an original signal consisting of $n$ values to an accumulation of the same number of $n$ coordinates, each corresponding to one from a family of wavelets. These wavelets are template patterns that all have the same basic shape (resembling a localized wave), but different amplitudes, wavelengths and phases. Each coordinate relates to a unique combination of a wavelength and a phase and the coordinate value itself expresses the amplitude. Wavelets are commonly used in image processing, in particular image compression. For such two-dimensional applications the wavelet transformation is first applied on the rows and then on the transformed columns.

In this chapter wavelet transformation separate the data into different scales. These separate scales are found by selecting from all coordinates of the wavelet transformation those that correspond to the particular wavelength and perform an inverse wavelet transformation on those only. Colloquially said: The wavelet approach transforms the original dataset into a large collection of local waves. The comparison at a scale is based on only those waves whose wavelength corresponds to that particular scale.

There are different types of wavelets and one aspect differentiating them is whether they are continuous or discrete. We follow Briggs \& Levine (1997) and use discrete wavelets. This means that wavelengths come in powers of 2 and wavelets are arranged head to tail. For instance, a signal consisting of 16 values will be decomposed into 8 wavelets of length 2, 4 of length 4,2 of length 8,1 of length 16 and finally one value for the overall mean.

The second differentiating factor of wavelet types is their template pattern (i.e. the shape of the wavelet), called mother wavelet. Restrictions to possible forms of mother wavelets arise from the condition that wavelets derived from a single mother wavelet need to be orthogonal and orthonormal. The simplest of mother wavelets is the Haar wavelet, most common are Daubechies wavelets.

This chapter applies the Haar wavelet. It is not selected on the basis of simplicity, but following the information based criterion recommended by Briggs \& Levine (1997). A second motivation for using the Haar wavelet is that the earlier mentioned restrictions make it the only symmetrical wavelet and all others would introduce anisotropy. Although these are valid arguments, there are no overwhelming arguments against other mother wavelets. The choice of mother wavelet is, thus, more or less arbitrary and will be considered in the sensitivity analysis (Section 6.4.2). 
For an in depth discussion of wavelet based map comparison we refer to Briggs \& Levine (1997) and Zepeda-Arce et al. (2000).

Equation 6.2 expresses that the original criterion map is decomposed into a series of maps by wavelet transformation.

$$
\begin{aligned}
& C_{\text {real }} \stackrel{W T}{\longrightarrow}\left\{C_{\text {real }}^{1}, C_{\text {real }}^{2} \ldots, C_{\text {real }}^{n \text { max }}\right\} \\
& C_{\text {real }}^{1}+C_{\text {real }}^{2} \ldots+C_{\text {real }}^{n \text { max }}=C_{\text {real }}
\end{aligned}
$$

where the numbers $1,2, \ldots, n \max$ indicate different scales. $C$ is any of the 4 criterion maps (presence of agriculture, presence of urbam, patch size of urban and fractal dimension of urban). The wavelet transform is performed for the real as well as the model map.

The cell-to-cell errors at every scale are aggregated to a mean squared error (MSE), following Briggs \& Levine (1997).

$$
M S E_{C, s}(\text { real }, \text { model })=\frac{\sum_{\text {cell }}\left(C_{\text {real,cell }}^{s}-C_{\text {model }, \text { cell }}^{s}\right)^{2}}{n \text { Cells }}
$$

Equation 6.3

where $C$ is the evaluated criterion and $s$ the scale at which it is evaluated. The index cell iterates over all cells of which there are $n$ Cells. As an illustration, figure 6.2 shows the squared error per cell for the criterion urban presence at multiple scales. The underlying data is presented in section 6.3 . 


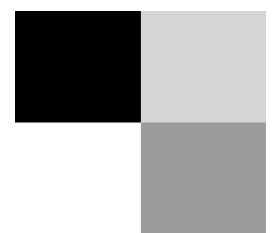

a. $256 * 256$

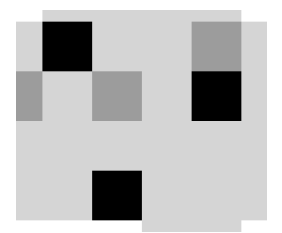

c. $64 * 64$

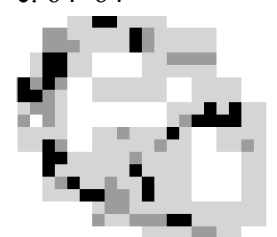

e. $16 * 16$

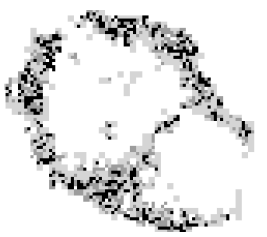

g. $4 * 4$

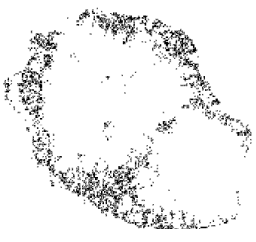

i. $1 * 1$

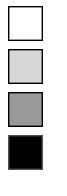

0 - 9.3E-9

9.3E-9 -6.7E-6

$6.7 \mathrm{E}-6-1.4 \mathrm{E}-5$

$1.4 \mathrm{E}-5-1.8 \mathrm{E}-5$
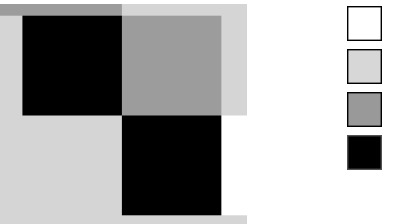

$0-6.7 \mathrm{E}-8$

6.7E-8 - 1.1E-5

1.1E-5 - 2.2E-5

$2.2 \mathrm{E}-5-6.0 \mathrm{E}-5$

b. $128 * 128$

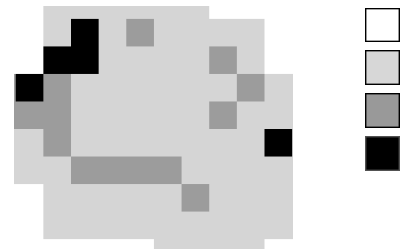

0 - 6E-21

$6 \mathrm{E}-21-1.1 \mathrm{E}-4$

$1.1 \mathrm{E}-4-4.6 \mathrm{E}-4$

4.6E-4 - 3.0E-3

d. $32 * 32$
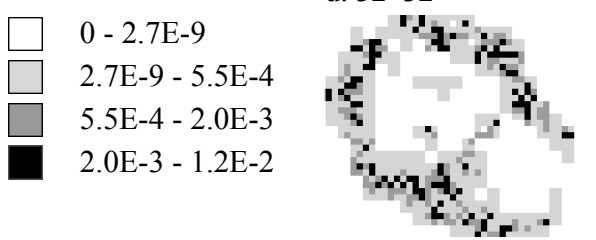

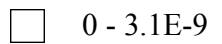

$3.1 \mathrm{E}-9-1.2 \mathrm{E}-3$

$1.2 \mathrm{E}-3-5.4 \mathrm{E}-3$

$5.4 \mathrm{E}-3-8.6 \mathrm{E}-2$

f. $8^{*} 8$
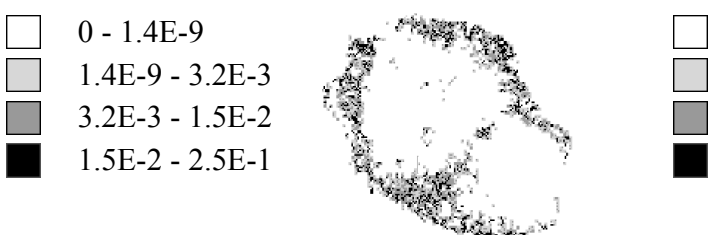

0 - 8.5E-8

$8.5 \mathrm{E}-8-8.6 \mathrm{E}-3$

$8.6 \mathrm{E}-3-4.3 \mathrm{E}-2$

4.3E-2 - 7.7E-1

h. $2 * 2$

$0-6.3 \mathrm{E}-8$

6.3-8 - 2.7E-2

$2.7 \mathrm{E}-2-1.5 \mathrm{E}-1$

$1.5 \mathrm{E}-1-2.3$

Figure 6.2 Haar wavelet decomposition of the error in urban presence

\subsubsection{Normalization}

The change over the simulation period is used as a means of normalization. The change over the simulation period is measured according to the same metric that expresses the model error. The two neutral models described in the previous section are used as a reference level. In summary, the following five maps are input to the analysis.

1. INIT: Initial ground truth map (initial year)

2. FINAL: Final ground truth map (final year)

3. SIM: Evaluated land use model (final year) 
4. RCM: Random Constraint Match (final year)

5. CLUST: Growing Clusters (final year)

Applying these abbreviations the normalized performance of the three models is calculated according to the following equations.

$$
\begin{aligned}
& P_{C, s}^{S I M}=\frac{M S E_{C, s}(\text { FINAL,SIM })}{M S E_{C, s}(\text { FINAL, INIT })} \\
& P_{C, s}^{R C M}=\frac{M S E_{C, s}(\text { FINAL, } R C M)}{M S E_{C, s}(\text { FINAL, INIT })} \\
& P_{C, s}^{C L U S T}=\frac{M S E_{C, s}(\text { FINAL,CLUST })}{M S E_{C, s}(\text { FINAL, INIT })}
\end{aligned}
$$

Equation 6.4

where $P$ is the performance metric applied in this chapter. $C$ stands for any of the four criterion maps and $s$ is the scale at which the model is evaluated. $P$ is the final measure of goodness-of-fit and can be summarized in plots and tables to concisely express the performance at multiple scales and relative to the different reference models. It is an error metric, so lower values indicate better performance.

\subsection{The case of La Réunion: study area, data and model}

\subsubsection{Study area}

La Réunion belongs to the Mascareignes archipelago in the Indian Ocean with Mauritius and the Gambrani islands situated east of Madagascar (figure 6.3). Politically, La Réunion belongs to the overseas French departments. It is one of the seven Ultraperipheral European Regions with the same status as regions on the European mainland.

The island covers $2512 \mathrm{~km}^{2}$ but only $1000 \mathrm{~km}^{2}$ are available for human activities, because of the steep slopes that are found on the island. The highest peak is $3070 \mathrm{~m}$ (Piton des Neiges) and is one of the world's most active volcanoes. Another restriction is formed by tropical forest which covers 1000 $\mathrm{km}^{2}$ and has a highly protected status. 


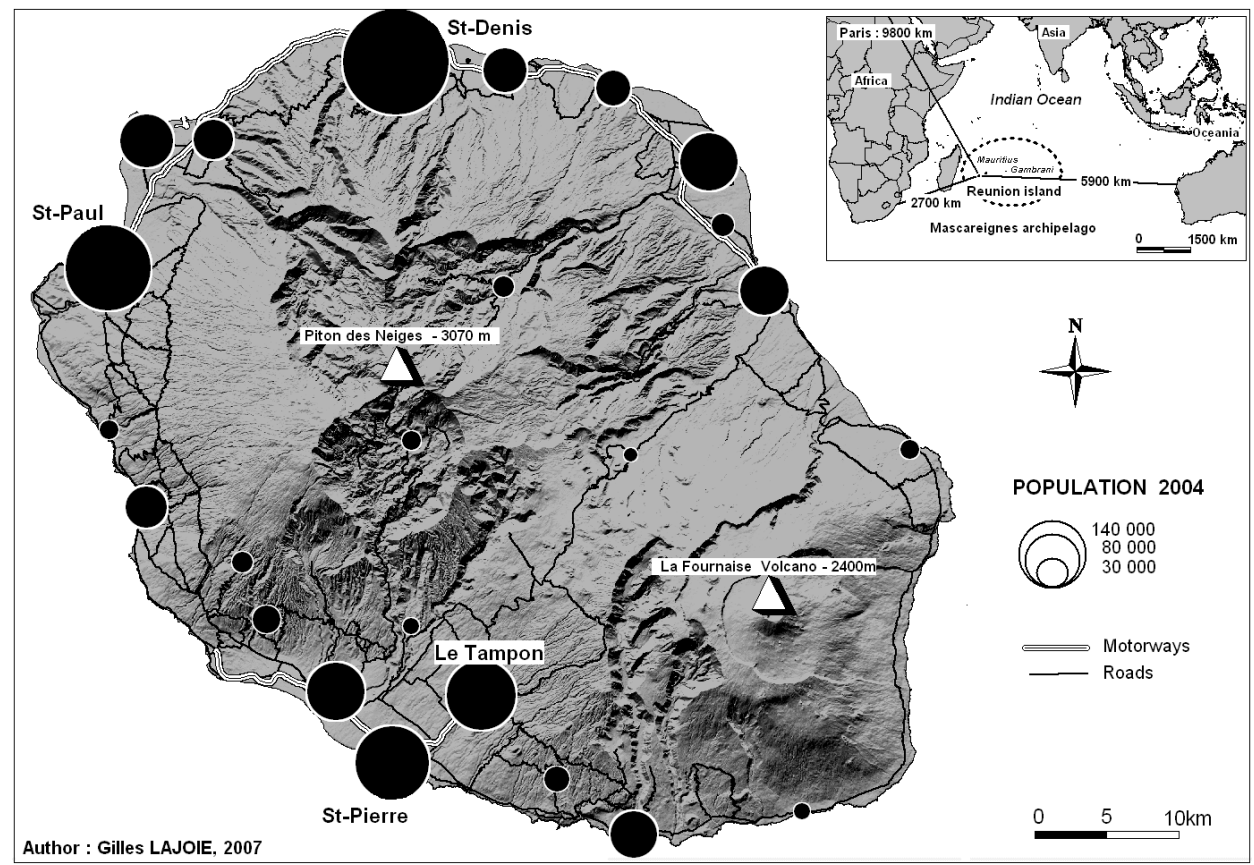

Figure 6.3 Geographical setting of La Réunion

Over the last twenty years the island has undergone some profound changes. The population increased from 590000 inhabitants in 1989 to 740000 in 2002 and will reach 1000000 in 2028 according to demographic projections of the National Institute of Statistics (Lardoux 2002). The economy has grown too and land has become scarce.

The land use model is calibrated over the period 1989 - 2002. In this period, urban development and the associated recession of forest and agriculture were the main processes of land use change (Lagabrielle et al. 2005). The recession of agriculture is expressed by a decrease of 3000 ha of land of which $60 \%$ transformed into forest and $20 \%$ transformed into urban. This classic case of rapid recession of agriculture came unexpectedly because agriculture was the primary economic activity on the island for several decades. Transitions took place both from agriculture to forest and vice versa.

While agriculture declined in the Northeast, it expanded in the Southwest. The explanation is simple; urban growth found ideal conditions in the Northeast (absence of slope, good accessibility to the capital where economic activity is concentrated, low land prices, etc.). At the same time, irrigation made land in the Southwest suitable for agriculture thanks to a large construction project financed by the European Union that is planned to transform 7000 ha of savannah into sugar cane plantations over a period of thirty years (1983-2013). 


\subsubsection{Data}

The calibration of the model requires two land use datasets. The best available data for this purpose are the remote sensing classifications from the TEMOS program and in particular the Data Base Isle project (CNES 2005). This project supplies scientists with pre-processed, multi-temporal satellite and multi-sensor data, as well as multi-thematic measures of land characteristics.

These source data are two SPOT images with a resolution of 20 meters for 1989 and 2002. The classification of this data is detailed in the TEMOS project report (Lagabrielle et al. 2005). Fifty land cover categories are distinguished, of which the land use model uses five particularly stable aggregate classes (mixed vegetation, forest, agriculture, urban, bare land). Additionally, to complete the cover of the island, steep slopes $(>30 \%)$ and the littoral fringe have become separate classes.

Both images of 1989 and 2002 have been aggregated to grids of regular cells of 200 meters aside, every cell taking the dominant class among seven classes. Eventually, La Réunion is represented on a matrix of 286 rows and 323 columns. The choice of spatial resolution and categorical detail is not trivial. Categorical detail determines to a large extent the parameter space in the model, since there are a number of parameters for every pair of land use classes. As a consequence this choice impacts the degrees of freedom of the model and the risk of over calibration. For this reason the number of land use classes is kept as low as reasonably possible. The choice of model resolution is not just a matter of model precision; in fact the resolution of the model determines the dynamic behavior of the model (Benenson 2007). It does so in a technical sense because the software allows neighborhoods with a radius of maximally 8 cells, but also more fundamentally since the resolution determines the spatial unit at which the land use changes.

Suitability maps are based on a number of characteristics that are considered constant in time, in particular soil type, elevation and slope. Although some of this data has been collected after 1989, there is no reason to assume that the data is not a good representation of the conditions in 1989. The same holds for the road network that underlies the accessibility layer of the model. This data was collected for 2002, but the road network has not changed between 1989 and 2002 (new projects are planned for 2009-2019).

The land use maps of 1989 and 2002, as well as the simulated maps are presented in figure 6.4. 


\subsection{Results}

\subsubsection{Model performance at multiple scales and criteria}

The results for the performance indicator presence of agriculture are presented in table 6.1. The results indicate that the changes that occurred over time (the column INIT compares the initial map of 1989 to the final map of 2002) vary with scale. At finer scales the changes are larger. The errors of the three models (SIM, RCM and CLUST) follow this same trend. In fact there is a near perfect linear fit between error and historical change for all three models (the correlation is 0.997 or higher for all). When the errors (table 6.1a) are normalized to the historical change the results (table $6.1 \mathrm{~b}$ ) fall within a range that is more naturally interpreted. The value 0 still stands for a perfect match, but the value 1 stands for the error that corresponds to the level of historical change, in other words the performance of the model of persistence.

At coarser scales all models perform better than a model of persistence. The fact that the random constraint match and the growing clusters model display these 'good results' at coarse scales (and even perfect results at the coarsest scale), indicates that this achievement must be attributed to the constraints imposed on the model.

Of most interest is the performance of the CCA model (SIM) relative to the neutral models. Table $6.1 \mathrm{~b}$ indicates that only at coarse scales of $16 * 16$ to $256 * 256$ the model outperforms both. Table $6.1 \mathrm{~d}$ shows that in terms of cumulative results at each scale and all coarser scales the model outperforms the neutral models of landscape change at scales of $8 * 8$ to $256 * 256$. Figure 6.5 shows the graphs corresponding to table $7.1 \mathrm{~b}$ and $\mathrm{d}$. All other results are presented in this visual form. 
Table 6.1 Goodness-of-fit results for the criterion presence of agriculture.

a. Mean squared error (MSE) [*10-6]

\begin{tabular}{lllll}
\hline Scale & INIT & SIM & RCM & CLUST \\
\hline 512 X512 & 11 & 0 & 0 & 0 \\
256X256 & 49 & 1 & 30 & 35 \\
128X128 & 170 & 10 & 88 & 130 \\
64 X64 & 290 & 120 & 240 & 290 \\
32 X32 & 540 & 360 & 460 & 650 \\
16 X16 & 690 & 570 & 580 & 1200 \\
8 X8 & 1200 & 1400 & 1100 & 2300 \\
4 X4 & 2500 & 3200 & 2400 & 4800 \\
2 X2 & 5400 & 8200 & 5600 & 10000 \\
1 X1 & 17000 & 25000 & 18000 & 27000 \\
\hline
\end{tabular}

c. MSE cumulative over scales $\left[{ }^{*} 10^{-6}\right]$

\begin{tabular}{lllll}
\hline Scale & INIT & SIM & RCM & CLUST \\
\hline $512 X 512$ & 11 & 0 & 0 & 0 \\
256X256 & 60 & 1 & 30 & 35 \\
128X128 & 230 & 12 & 120 & 160 \\
$64 X 64$ & 520 & 140 & 360 & 460 \\
$32 X 32$ & 1100 & 500 & 810 & 1100 \\
$16 X 16$ & 1800 & 1100 & 1400 & 2300 \\
$8 X 8$ & 2900 & 2400 & 2500 & 4700 \\
$4 X 4$ & 5400 & 5600 & 5000 & 9500 \\
2X2 & 11000 & 14000 & 11000 & 20000 \\
$1 X 1$ & 28000 & 39000 & 29000 & 47000 \\
\hline INIT = Initial map (1989) \\
SIM = Constrained Cellular Automata simulation (2002 \\
RCM = Neutral Model: Random Constraint(2002) \\
CLUST = Neutral Model: Growing Clusters (2002) \\
The best fit per scale is highlighted
\end{tabular}

b. MSE normalized to INIT

\begin{tabular}{llll}
\hline Scale & SIM & RCM & CLUST \\
\hline 512X512 & 0.00 & 0.00 & 0.00 \\
256X256 & 0.03 & 0.61 & 0.71 \\
128X128 & 0.06 & 0.53 & 0.78 \\
$64 X 64$ & 0.43 & 0.82 & 1.00 \\
32X32 & 0.67 & 0.84 & 1.19 \\
$16 \times 16$ & 0.82 & 0.85 & 1.76 \\
$8 \times 8$ & 1.14 & 0.94 & 1.97 \\
$4 \times 4$ & 1.28 & 0.98 & 1.93 \\
$2 \times 2$ & 1.52 & 1.04 & 1.89 \\
$1 \times 1$ & 1.49 & 1.08 & 1.60 \\
\hline
\end{tabular}

d. MSE cumulative over scales normalized to INIT

\begin{tabular}{llll}
\hline Scale & SIM & RCM & CLUST \\
\hline 512X512 & 0.00 & 0.00 & 0.00 \\
256X256 & 0.02 & 0.50 & 0.58 \\
128X128 & 0.05 & 0.52 & 0.73 \\
64X64 & 0.26 & 0.69 & 0.88 \\
32X32 & 0.47 & 0.76 & 1.04 \\
16X16 & 0.61 & 0.80 & 1.32 \\
8X8 & 0.83 & 0.86 & 1.58 \\
4X4 & 1.03 & 0.91 & 1.74 \\
2X2 & 1.28 & 0.98 & 1.82 \\
1 X1 & 1.41 & 1.04 & 1.69 \\
\hline
\end{tabular}




\section{Chapter 6}
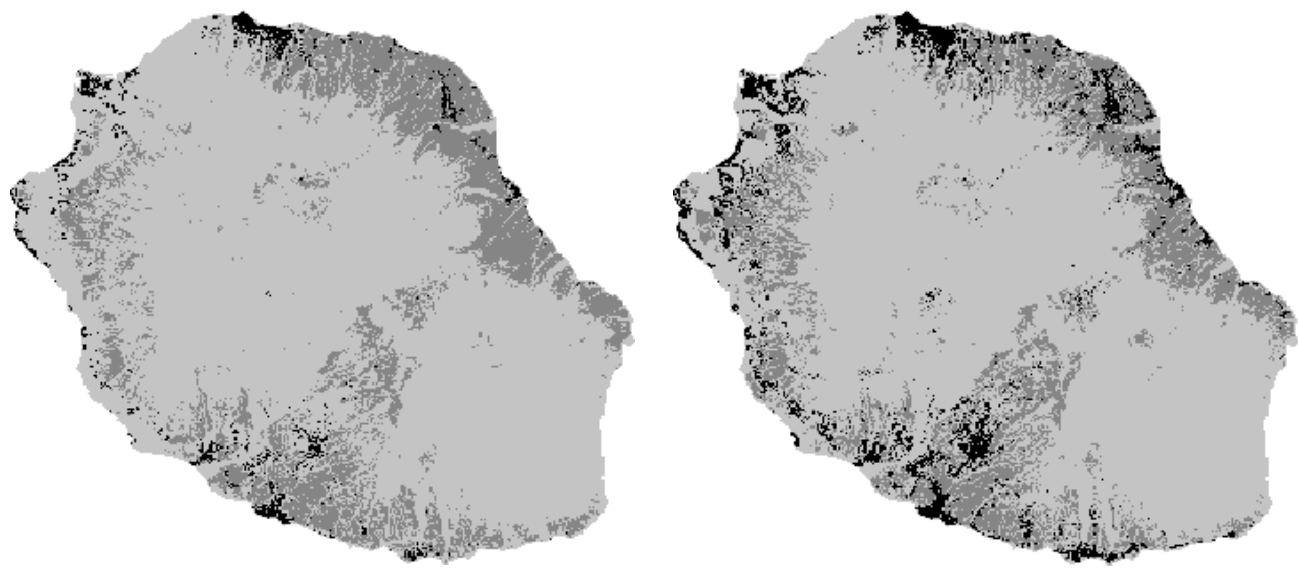

a. Ground truth 1989 (INIT)

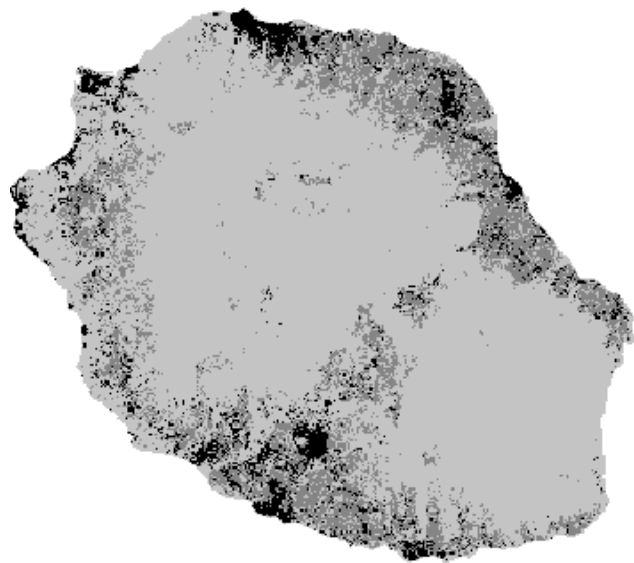

b. Ground truth 2002 (FINAL)

c. Simulation 2002 (SIM)

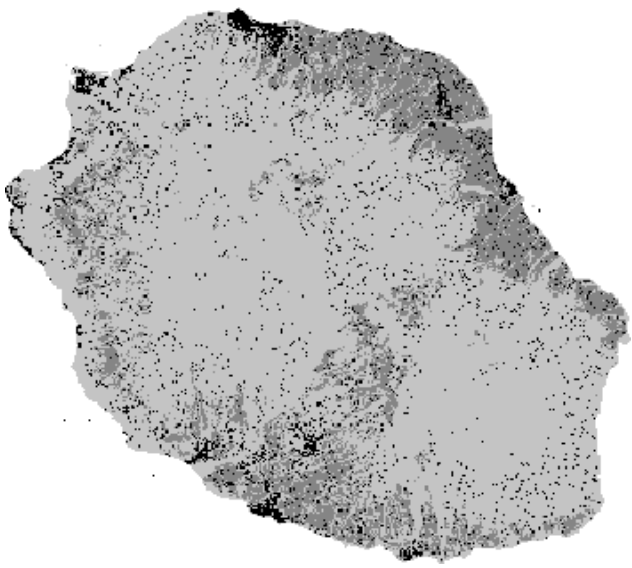

d. Random constraint match 2002 (RCM)
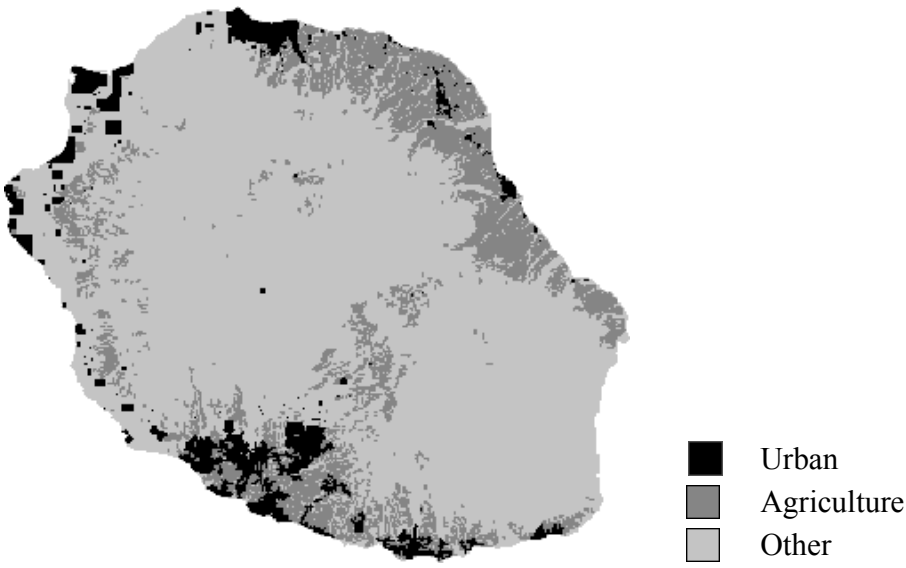

e. Growing clusters 2002 (CLUST)

Figure 6.4 Five land use maps, the original legend has been reduced to three main classes (after simulation) for legibility 


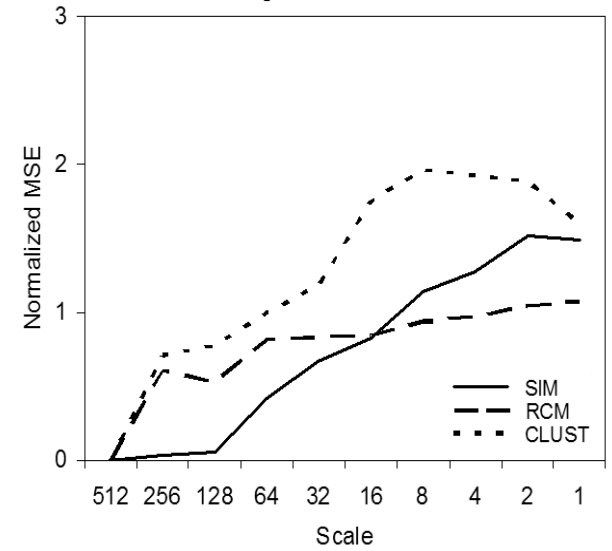

a. Each scale represents a wavelength

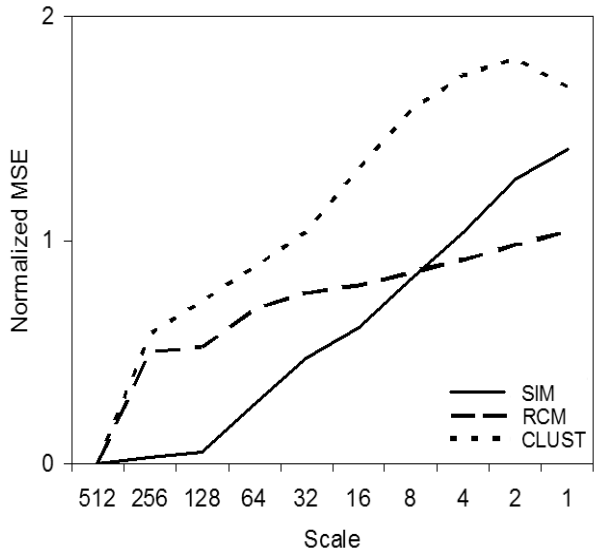

b. Cumulative: Each scale represents a wavelength and all larger wavelengths combined

Figure 6.5 Multi-scale goodness-of-fit of presence of agriculture, with coarse scales on the left and fine scales on the right

A closer look at the change patterns of the agricultural land use class may illuminate these results. Figure 6.6 illustrates that the change patterns that occurred in reality consisted of appearing agriculture at some cells and disappearing at other. The same holds for the changes that occurred in the model, but not in the random constraint match model, since this model minimizes overall change.

Results for presence criterion of urban are similar to those of agriculture (figure $6.7 \mathrm{a}-\mathrm{b}$ ); the CCA only outperforms the neutral models of landscape change at the mid range of scales $(8 * 8$ to $32 * 32)$. When spatial structure is considered the results are quite different. In terms of urban patch size (figure 6.7c) the neutral models are outperformed at all scales and on the criterion of fractal dimension at all scales except $32 * 32$ (figure $6.2 \mathrm{~d}$ ).

\subsubsection{Sensitivity}

In the course of the analysis, several choices have been made that are essentially arbitrary. In this section the impact of those decisions is investigated. The following three arbitrary decisions are considered.

1. The choice of the mother wavelet

2. The strategy for padding the image to 512 by 512 cells

3 . The choice of evaluating only a single model run

For the analysis we used the Haar wavelet. Although we provided motivation for this choice of mother wavelet, the selection is more or less arbitrary 


\section{Chapter 6}
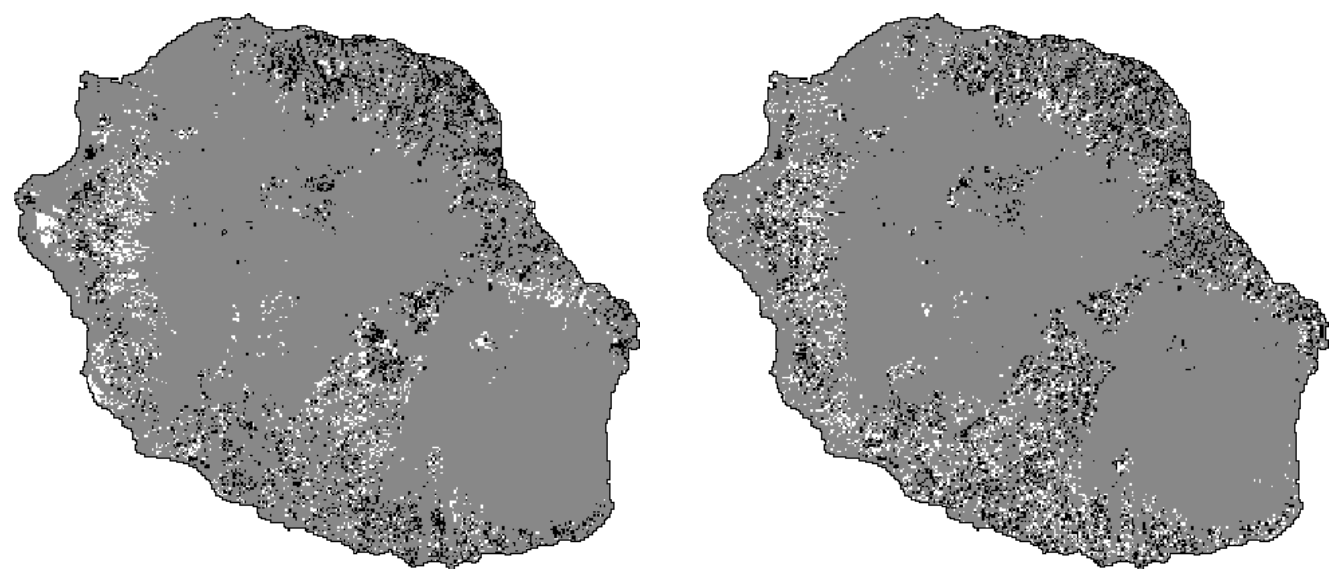

a. Ground truth

b. Simulation

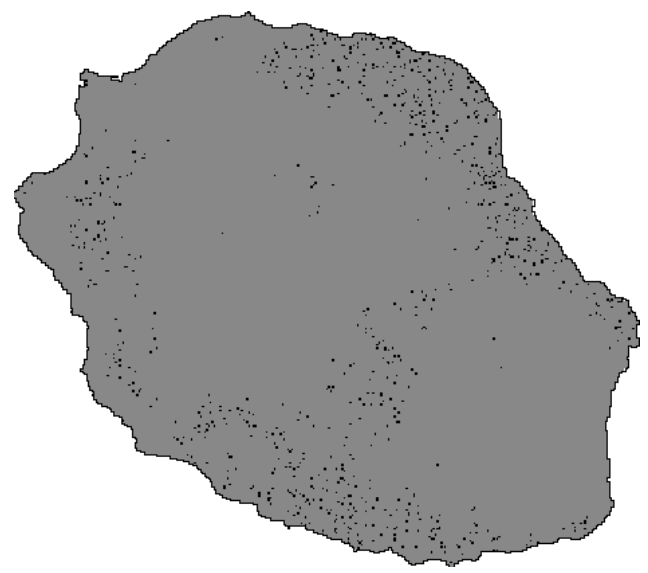

c. Random constraint match

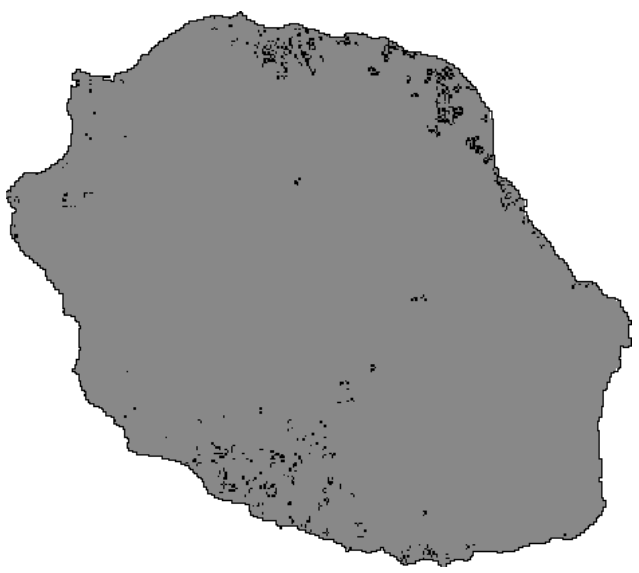

d. Growing clusters

$\square$ Agriculture unchanged

$\square$ Agriculture appeared

- Agriculture disappeared

Figure 6.6 Patterns of agricultural change 

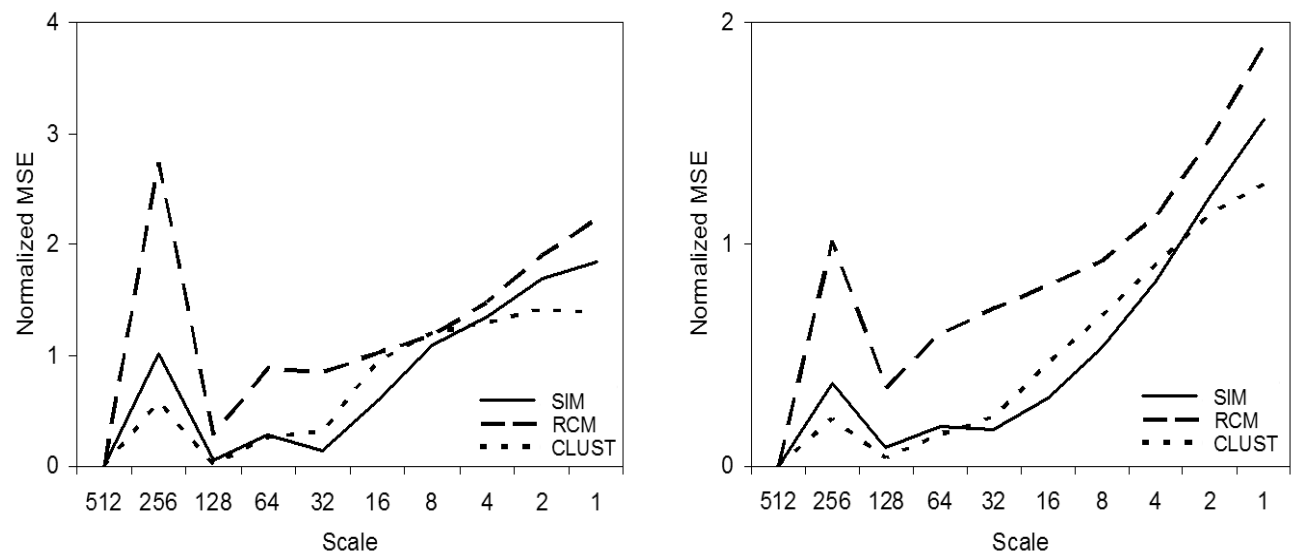

a. Presence

b. Presence cumulative
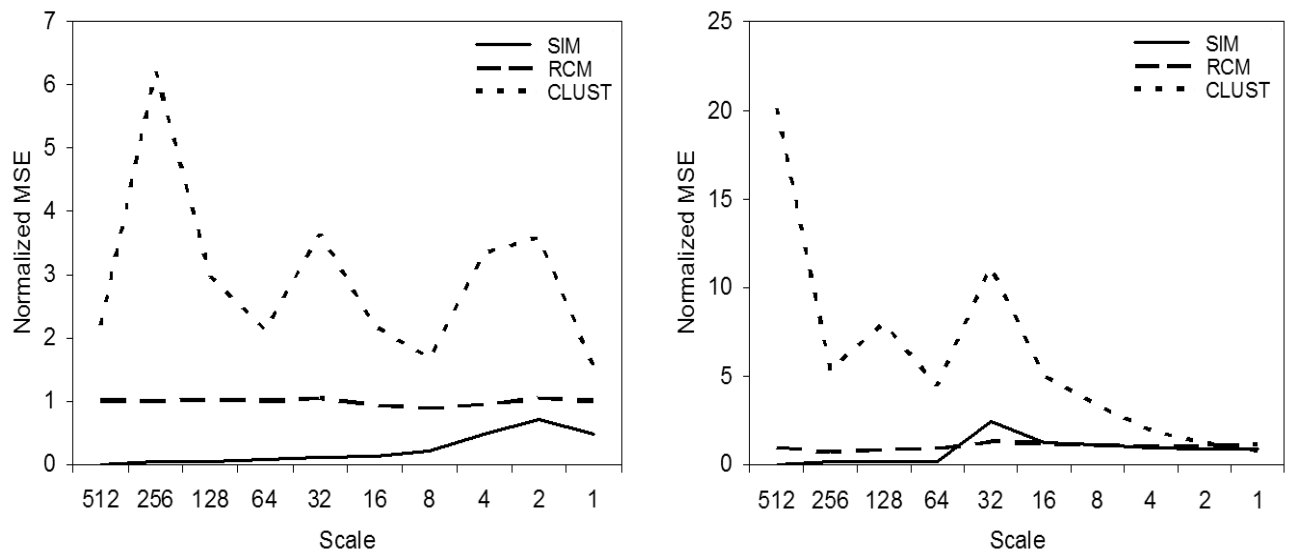

d. Fractal dimension

c. Patch size

Figure 6.7 Multiscale goodness-of-fit for the class urban, with coarse scales on the left and fine scales on the right

The evaluation of similarity of agriculture presence is recalculated twice, on the basis of a Daubechies 4 and Daubechies 16 wavelets (figure 6.8). Comparison to the earlier results (figure 6.5a) makes clear that the choice of mother wavelet substantially impacts the analysis. For instance, at scale $16^{*} 16$ the CCA model outperforms the reference models according to the Haar wavelet, but not according to the Daubechies wavelets. At the coarsest scales the CCA model outperforms the neutral models of landscape change according to the Daubechies 4 and 16 wavelets, but not according to the Haar wavelet. 


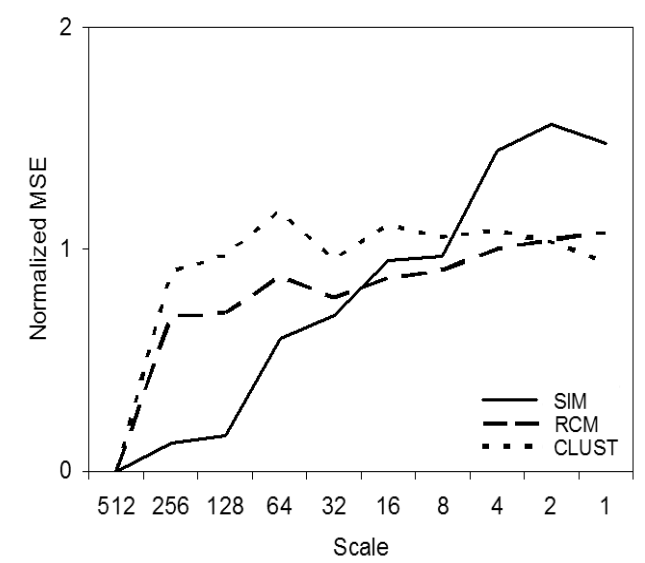

a. Daubechies 4

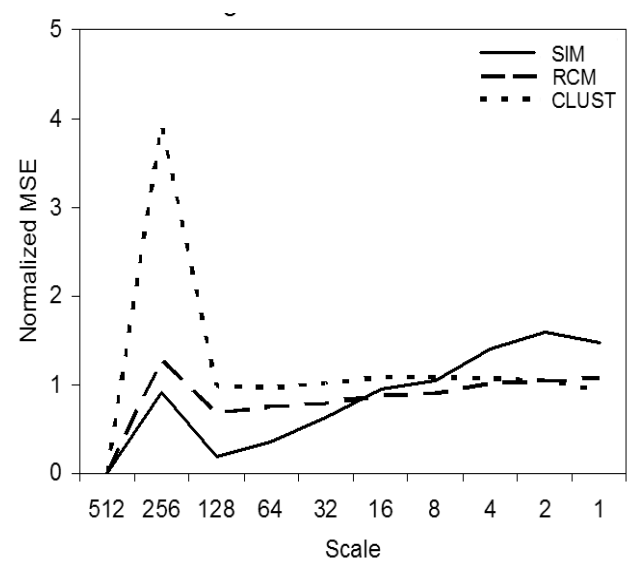

b. Daubechies 16

Figure 6.8 Multi-scale goodness-of-fit of agriculture according to Daubechies wavelets

The discrete wavelet transform requires data in strings of $2^{\mathrm{n}}$ elements. The original map has the dimension of 286 by 323 cells. In order to be processed in the wavelet analysis, all maps had to be padded to 512 by 512 cells. With padding is meant that at the sides of the map rows and columns are added to obtain the right dimension. Since La Réunion is an island, in effect padding includes a larger part of the ocean in the analysis. There are different options available considering how many rows are added in the North or the South and columns in the East or the West. The results presented so far have been based on the strategy of centering the original map on the padded map (i.e. the island lays in the middle of the ocean). One alternative is to place the original map on the upper-left corner of the padded map. This is the approach used to attain the results of (figure 6.9a). In comparison to earlier results (figure 6.7a) the errors have shifted between scales. Most strikingly, the peak in the error that was originally registered at the scale of $128^{*} 128$ is now found at $256^{*} 256$. At the finer scales the errors are approximately the same.

All three models have a stochastic component. Monte Carlo analysis of the distribution of goodness-of-fit is an option for further statistical rigor. The double graphs of figure $6.9 \mathrm{~b}$ show best and worst fit over five runs of each model. It shows that the relative ordering of the models is most unclear around scale $8 * 8$ where the lines intersect and at the coarse scales of $64 * 64$ to $256 * 256$.

Of the three arbitrary decisions, the padding strategy influences the results most strongly. 


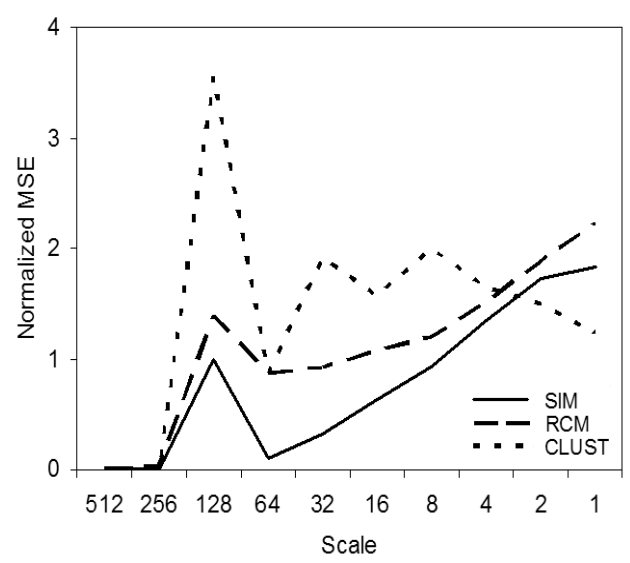

a. Alternative padding strategy

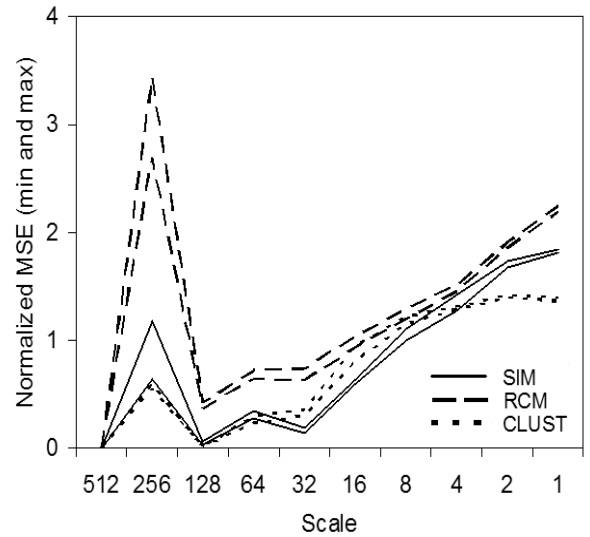

b. Monte Carlo

Figure 6.9 Multi-scale goodness-of-fit of urban presence under alternative padding options and Monte Carlo simulation

\subsection{Discussion}

The model evaluation period is the same period that is also used for the model calibration, namely 1989-2002. This is not the ideal case as preferably model performance is measured over a separate validation period or otherwise independent data set. Good results for the calibration period, therefore, do not necessarily indicate good predictive quality. Temporal stationarity is not investigated and there is a risk of over-calibration. The consequence is that our conclusions only reflect how well the model can reproduce historical land use patterns and not how well it can be expected to predict future developments.

Results at the coarsest scale form a special case. At this scale, maps are represented by the mean over the map. Since the total presence of agriculture and urban area is exogenous to both the CCA model and the reference models, all perform identical (and perfect) at this scale for the presence criteria. Other coarse scales must be considered with caution; the discrete nature of wavelets and relatively small number of coordinates at this level (refer back to figure 6.2) make results at this scale highly sensitive to the arbitrary positioning of the wavelet patterns. This is confirmed by the sensitivity analysis. The multi-scale assessment seems stable at scales $1 * 1$ to $64 * 64$ at coarser scales there is too little information and the results are overshadowed by the uncertainties posed by arbitrary decisions. Note that at $64 * 64$ the whole island is captured by less than 30 cells.

The comparison of normalized results of the four criteria indicates that the model performs best in terms of urban patch size (figure 6.10 plots all criteria on the same scale). The strong contrast between performance of the model and 


\section{Chapter 6}

the neutral models of landscape change indicates that the similarity in structure can be attributed to the processes of the CCA model. Barring the unreliable results at the coarsest scales, the results indicate that the Constrained Cellular Automata outperforms neutral models at coarse scales for all criteria. In terms of structure, and particularly patch size, the CCA outperforms the neutral models at all scales.

The performance of the random constraint match model for fractal dimension is remarkable. How can this blunt neutral model form competition to the CCA when it comes to a criterion of patch shape? A visual assessment of the maps shows that the shape of the patches is not at all realistic; in fact the model only adds speckles of size 1 . The fractal dimension metric may have been ill-chosen for the current case. At the resolution of $200 \mathrm{~m}$ many urban patches consist of only a few cells and the metric value is then determined largely by the small number of possible configurations rather than the actual shape of the patch.

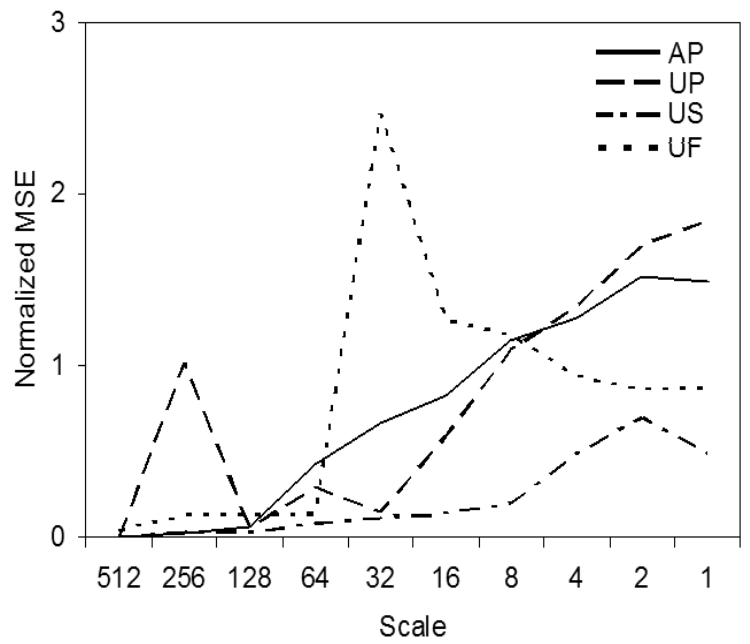

Figure 6.10 Multi-scale, multi-criteria goodness-of-fit. Agriculture presence (AP), Urban presence (UP), Urban Urban patch size (US) and Urban fractal dimension (UF)

A remarkable error of urban presence is found at the coarse scale of $256 * 256$ $\left(128^{*} 128\right.$ in the analysis based on alternative padding). This is an indication that one or more large scale processes are insufficiently captured by the model. Several strong gradients over the island may be the explanation. The first gradient is climatic; the East receives $4000-5000 \mathrm{~mm}$ rain per year whereas the West receives less than $1000 \mathrm{~mm}$ per year. Another gradient is socio-economic; the model considers only a single urban class, but the characteristics of this class differ regionally in terms of population density and economic profile. 


\subsection{Conclusion}

The performance of spatial models can be measured according to many different criteria. The problem arises that scores for these criteria are not mutually comparable and moreover that scores on identical criteria may not be comparable when applied at different scales or for different applications, since the context of the model determines the appropriate interpretation. The framework for model performance assessment proposed in this chapter addresses both problems by first normalizing to the level of historical change and secondly expressing the model performance relative to that of neutral models of landscape change.

The development of rigorous frameworks for the evaluation of model performance is crucial to advance the field of land use modeling. As the field is developing, advances increasingly depend on systematic empirical analysis. An example of a frontier of new developments is the investigation of scaledependency in CA land use models (Benenson 2007). Scale dependency is of course known for a long time, but only recently studies are appearing that systematically investigate the sensitivity to resolution and scale (e.g. Jantz \& Goetz 2005, Kocabas \& Dragicevic 2006, Ménard \& Marceau 2005, Samat 2006). All these studies present multi-scale analyses in similar fashion to this chapter. The difference is that these studies analyze the results of models that are applied on multiple scales, whereas the model in this chapter is only applied at a single resolution. These studies are confronted by the same problem that as the scale of analysis changes, the appropriate reference level for different performance criteria changes as well. Application of the methodological framework of this chapter would enhance the interpretation given to the results in these studies.

Neutral models of landscape change are a new class of neutral landscape models. Their innovation is that instead of creating a landscape from scratch, they modify an initial landscape until all constraints are satisfied. This dynamic character is crucial if neutral landscape models are to be used in relation to the process of land use change. The potential for application of neutral models of landscape change is not restricted to land use modelling purposes. Any landscape analysis with temporal aspects can benefit from neutral models of landscape change. The models can be employed to test hypotheses about patterns of change in the landscape rather than the landscape patterns themselves. 



\section{Prospects for comparing patterns of change}

\subsection{Introduction}

The methods presented in the previous chapters are suited for the operational validation (Rykiel 1996) of spatial models. The models are run for a period in the past, after which the simulated map is compared to a map of reality. By invoking different criteria and scales the methods present rich information on strengths and weaknesses of the examined model.

This chapter explores the possibilities of a method that does not compare the end state of a simulation to reality, but instead compares the changes that are generated by the model with those that took place in reality; i.e. the method is based on the comparison of transitions. The transitions are compared on the basis of various cell attributes that together describe a state-space. Therefore the method is based on a comparison of transitions in state-space.

By evaluating patterns of change instead of patterns of the end state, the approach evaluates more directly the model's processes than do the methods discussed in the earlier chapters. An additional advantage is that the state-space representation is not bound to particular locations; the approach evaluates whether units with a similar set of characteristics change according to similar patterns. It allows comparison of change patterns of regions that do not overlap, or only partly overlap.

This suggests that the method is also useful for providing descriptive statistics of land use change. In other words, it can be used to assess the performance of a model, but also to summarize historical land use change patterns. The approach differs from common descriptive models of land use patterns that summarize the land use at a given time in one or more variables. Those variables can be simple, e.g. the total built up area, or complex, e.g. fractal dimension or the slope of a cluster-size distribution plot, but generally do not address the dynamics of the urban system.

There seems to be scope for a classification system of spatial dynamics. Would it not be interesting - and useful - if we could recognize the fingerprint of urbanisation of different regions and times? To know, for instance, if an urban region is developing more like LA in the 1990's or NY in the 1920's. Or to 


\section{Chapter 7}

evaluate in an urban planning context, whether the patterns of urbanisation indeed follow the objectives laid out by planners. It would then be possible to take action before unwanted dynamics have taken their full effect.

This chapter does not intend to provide the definite classification or method. Instead, by a relatively simple experiment, it explores the use of the state-space approach for map comparison and classification of urban dynamics. The experiment revisits the model of La Réunion evaluated in chapter 6; Now, the model is evaluated in terms of patterns of change. The advantage over the earlier application is that now the evaluated

\subsection{Method}

The comparison method is based on the comparison of one or more raster maps. Every cell in the maps is characterized by a number of attributes. Those attributes can be the values found in the raster maps, such as land use class or population number, but can also be derived attributes, such as the number of residential cells within a given radius.

The various characteristics represent dimensions in state-space. As a cell's attributes change over time, its position in state-space changes accordingly. In order to facilitate the tabulation of transitions in state-space, a categorization is made that divides the whole state-space in $n$ categories. Transitions in statespace over a given time can than be summarized in an $n$ by $n$ transition matrix.

Since the comparison is intended to be on the types of transitions that take place and not on the actual state of the maps, the transition diagram is normalized, such that its cells represent frequencies of transition, i.e. the sum over all frequencies for any initial class is always 1 .

The creation of the transition matrix is illustrated step-by-step for an artificial example. In this example there are two attributes that comprise state-space; 'housing density within $500 \mathrm{~m}$ radius' and 'distance to nature'. These two attributes are the axes against which the state-space plot is drawn. Figure 7.1 illustrates how a location changes attributes and moves through state-space in consecutive time steps. Transitions in state-space are made at all locations and can be summarized in a single plot as in figure 7.2. All transitions together may be further summarized in a transition matrix (table 7.1) on the basis of a categorization as in figure 7.3 


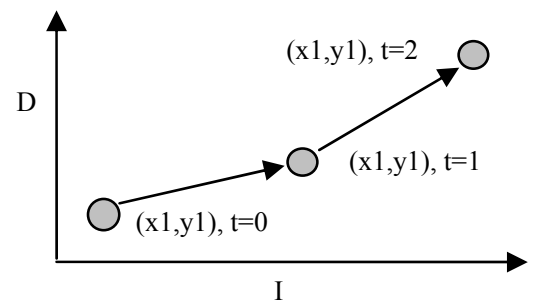

Figure 7.1 The geographical location $(x 1, y 1)$ changes location in state-space over time. The two axes represent distance to nature (vertical) and inhabitants within a $500 \mathrm{~m}$ radius (horizontal). Through time the location gains inhabitants and becomes further away from nature.

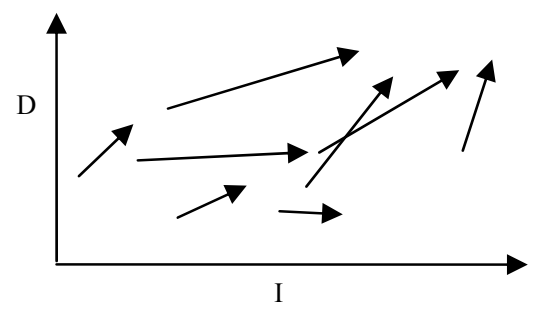

Figure 7.2 All locations combined provide a summary of the changes in the map.

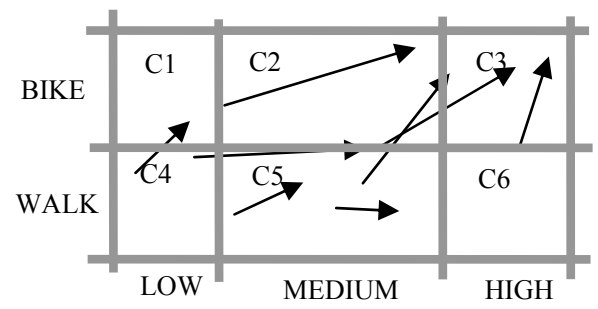

Figure 7.3 A simple classification yields six categories. Distance to nature is expressed in two bins for biking and walking distance. Number of inhabitant ranges is classified as \{low, medium, high\} 
Table 7.1 The normalized transition matrix tabulates all changes that occurred.

\begin{tabular}{lllllllll}
\hline & & $\mathrm{t}+1$ & & & & & \\
& & $\mathrm{C} 1$ & $\mathrm{C} 2$ & $\mathrm{C} 3$ & $\mathrm{C} 4$ & $\mathrm{C} 5$ & $\mathrm{C} 6$ & $\mathrm{SUM}$ \\
\hline $\mathrm{T}$ & $\mathrm{C} 1$ & $\mathrm{~T}_{1,1}$ & $\mathrm{~T}_{1,2}$ & etc. & & & & $100 \%$ \\
& $\mathrm{C} 2$ & $\mathrm{~T}_{2,1}$ & $\mathrm{~T}_{2,2}$ & & & & & $100 \%$ \\
$\mathrm{C} 3$ & etc. & & & & & $100 \%$ \\
$\mathrm{C} 4$ & & & & & & $100 \%$ \\
$\mathrm{C} 5$ & & & & & & $100 \%$ \\
$\mathrm{C} 6$ & & & & & & $100 \%$ \\
\hline
\end{tabular}

The transitions of two pairs of maps are compared by a (matrix)cell-by-cell comparison of the transition matrices. A provision is made for those state-space categories that are in the initial situation not present in one of the two map pairs, according to the following equation:

$$
\mathrm{d}(\mathrm{A}, \mathrm{B})=\frac{\sum_{\mathrm{i}, \mathrm{j}}\left(\left|\mathrm{A}_{\mathrm{i}, \mathrm{j}}-\mathrm{B}_{\mathrm{i}, \mathrm{j}}\right| * \mathrm{w}_{\mathrm{i}, \mathrm{A}, \mathrm{B}}\right)}{\sum_{\mathrm{i}} \mathrm{w}_{\mathrm{i}, \mathrm{A}, \mathrm{B}}}
$$

where:

$\mathrm{d}(\mathrm{A}, \mathrm{B})$ difference in transitions between regions $\mathrm{A}$ and $\mathrm{B}$

A, B two compared transition matrices

$A_{i, j} \quad$ fraction of locations originally in state $i$ that changes to state $j$.

$\mathrm{W}_{\mathrm{i}, \mathrm{A}, \mathrm{B}} \quad$ presence indicator, it takes value 1 if class $\mathrm{i}$ is present in the initial map of both pairs $\mathrm{A}$ and $\mathrm{B}$, and 0 otherwise.

If not a single class is present in both initial maps, then their dynamics can not be compared.

\subsection{Results}

Chapter 6 introduced the case of La Réunion. In this chapter the results are revisited and evaluated in terms of their state-space dynamics. As before, the results are compared against the performance of two neutral models of land use change; the growing clusters model and the random constraint match model. Additionally, two more models are evaluated; these are a previous, less exhaustively calibrated version of the model and a model that allocates land use cells randomly without taking the initial situation into account.

It is expected that the neutral models of landscape change are outperformed by both calibrated versions of the model. Furthermore it is expected that the neutral models of landscape change which meet de constraints by modifying the initial 
situation perform better than the traditional neutral model that creates a landscape without accounting for the initial situation.

In summary, there are 6 land use models. In order of expected similarity to ground truth, these are the following:

1. CCA model with elaborate calibration

2. CCA model with minimal calibration

3. Neutral models of landscape change

4. Random constraint match

5. Growing clusters

6. Random location

To reduce the dimensionality of the analysis, the maps have been reclassified to only four classes: Natural vegetation, Agriculture, Urban and Unused land. The maps (figure 7.4) are categorical raster maps with a resolution of 200 meters.

Each dimension in the state-space comparison refers to a single category. Of that category the prevalence (fraction of occurrence) within a circular neighbourhood is registered and is classified into 6 bins. Thus, in a moving windows analysis the percentage of occurrence for each of the four classes is calculated and a classification is made on the basis of maximum $6^{4}=1296$ classes. This is an overestimation since not all combinations are possible considering that the fractions must add up to 1 . In first instance the analysis is performed on the basis of a circular neighbourhood with a radius of 10 cells.

The results (table 7.2) indicate as expected that the transitions in the elaborately calibrated model are most similar to those in ground truth data. Also according to expectations, the neutral models that take into account the initial situation (random constraint match and growing clusters) perform distinctively better than the random location model that generates a landscape from scratch. It is surprising however that the minimally calibrated version of the model, does not outperform either neutral model of landscape change. Even though beforehand it was clear that this calibration is of less quality than the elaborate calibration, the predicate 'worse than random' indicates that the quality of the calibration was overestimated. 


\section{Chapter 7}

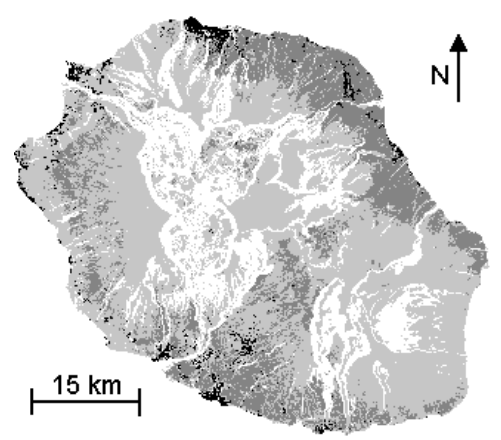

a. Ground truth 1989

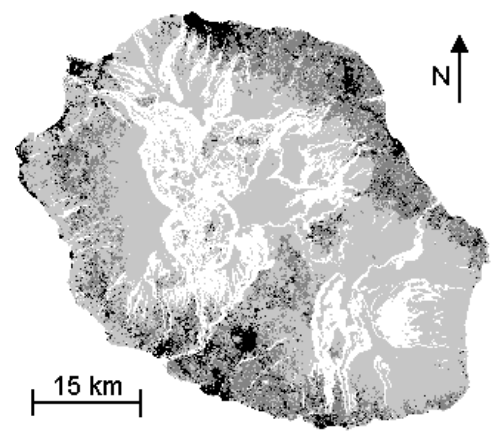

c. Elaborate calibration 2002

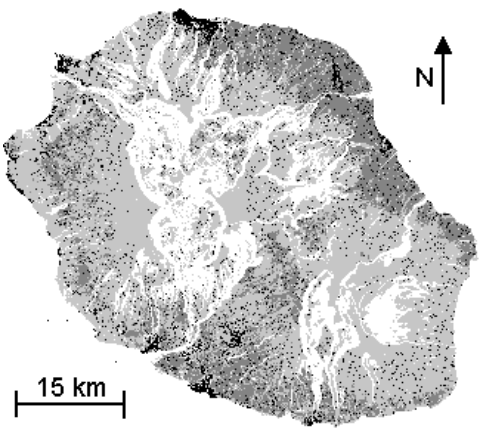

e. Random constraint match 2002

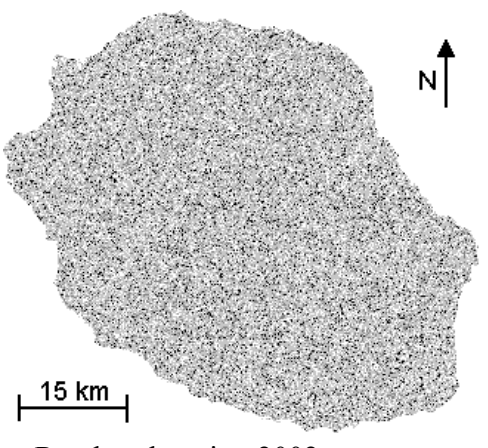

g. Random location 2002

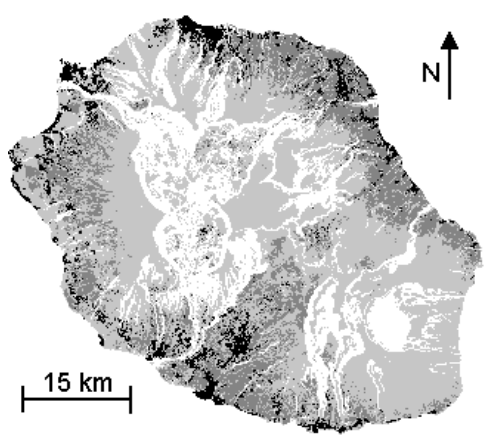

b. Ground truth 2002

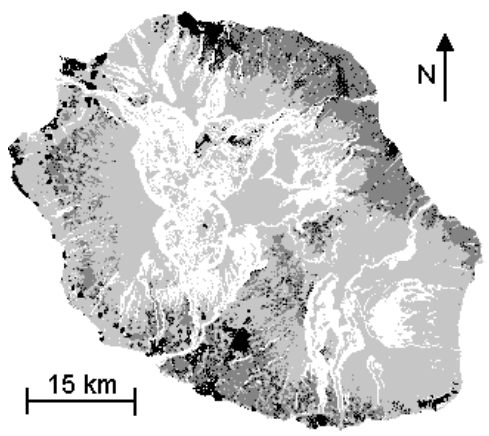

d. Minimal calibration 2002

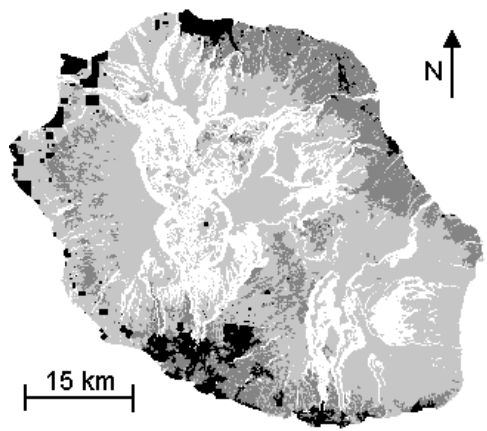

f. Growing clusters 2002

$\square$ Natural vegatation

Agriculture

Urban

Unused

Figure 7.4 Reclassified land use maps of La Réunion 
Table 7.2 Difference in transition pattern, based on land use fractions within a 10 cell radius.

\begin{tabular}{lll}
\hline & Score & Normalized \\
\hline Elaborate calibration & 43.0 & 0.42 \\
Minimal calibration & 79.4 & 0.78 \\
Random constraint match & 73.1 & 0.72 \\
Growing clusters & 74.6 & 0.73 \\
Random location & 130.5 & 1.28 \\
No change & 102.0 & 1 \\
\hline
\end{tabular}

The choice of a 10 cell radius is arbitrary, and therefore different radii are evaluated, establishing a multi-scale analysis. Chapter 6 indicated that models can be expected to predict non-change better than change. In this moving window approach fine scales by definition change more than coarse scales, hence there is a bias that considers maps at coarse scales more similar than those at fine scales. To overcome this bias the difference metrics are normalized to the level of actual change, following the framework of chapter 6 . The multiscale results after this normalization are found in table 7.3.

The multi-scale results are surprising because they indicate that the model is performing best at the finest scales. This is unexpected because chapter 6 pointed to the opposite. It is tempting to conclude that a realistic representation of fine-scale dynamics is responsible for coarse scale structural similarity. If this was the case, however, the best results should be found at the radius of spatial interaction of the CA model (maximum 8 cells) and not at a radius of 0 .

A possible explanation may be the number of categories within state-space. Earlier it was indicated that there are up to 1269 categories. At small radii however there are many fewer possible categories because of the discrete nature of the neighbourhood (e.g. a radius of 0 cells consists only of the cell itself and has 4 possible states, a radius of 1 cell yields a neighbourhood of 5 cells, which with 4 categories leaves 56 different distributions). Further research should indicate whether the distribution effects of the discrete nature of the neighbourhood configurations possibly introduces biases to the analysis. 
Table 7.3 Normalized differences in transition pattern based on land use fractions within 4 different radii.

\begin{tabular}{lllll}
\hline & $\mathrm{R}=0$ & $\mathrm{R}=5$ & $\mathrm{R}=10$ & $\mathrm{R}=20$ \\
\hline Elaborate calibration & 0.25 & 0.51 & 0.42 & 0.38 \\
Minimal calibration & 0.84 & 0.80 & 0.78 & 0.70 \\
Random constraint match & 0.80 & 0.74 & 0.72 & 0.70 \\
Growing clusters & 0.83 & 0.79 & 0.73 & 0.67 \\
Random location & 3.07 & 1.23 & 1.28 & 1.42 \\
\hline
\end{tabular}

\subsection{Conclusion}

This chapter introduces a method for the comparison of transitions in statespace. As a proof of concept the method is applied to a particular case. The experiment demonstrates how the comparison of changes over time can be a measure of model performance. The ranking of the different models of the experiment is largely according to expectations. The exception is the minimally calibrated version of a spatial land use model, which, as it turned out, performed more poorly than models of random change.

The experiments indicate good prospects for transition based descriptive modelling of urban change. Some weaknesses, however, are revealed as well.

The results from the multi-scale analysis raise doubts; possibly the corrections for non-occurrence of classes and the normalization to the level of historical change introduce biases to the analysis. A suggested line of research that may settle these questions is a formal elaboration on the basis of Markov Chains. In that work, a central topic would be to account for the lack of independence between observations.

Another drawback of the methodology is the loss of information due to classification, and, related to that, the curse of dimensionality. This curse holds that the number of classes grows exponentially with the number of dimensions and the number of observations per class reduces accordingly. Therefore, even though theoretically the number of characteristics and classes to distinguish is unlimited, in practice it is imperative to reduce to the essentials. 


\section{Discussion and conclusion}

\subsection{Comprehensive assessment of model performance}

This thesis argued that there is a need for performance criteria for geosimulation models and Cellular Automata land use models in particular. It is recognized that the recent developments in land use modelling resulting in high levels of operability and region specific applications call for a rigorous modelling process. Such a process is already well established in other fields, in particular hydrological modelling, and requires amongst others the steps of model calibration and validation. Both of these steps involve the formulation of goodness-of-fit criteria.

Measuring the performance of Cellular Automata land use models is particularly challenging: Even though the model is defined at the scale of the raster cell, the interest in the results is at coarser scales and in particular in the spatial structure that emerges. And this is where complications arise; there are many aspects of spatial structure and the question which aspect more appropriately addresses the performance of the model is not easily answered. It will depend on the particular circumstances of the region that is being modelled, the objective of the simulation and ultimately the personal preference of the analyst. As a consequence this thesis does not offer the one ultimate map comparison method to be used for all calibration and validation problems, such a method is not likely to exist. Instead, a range of methods is presented, most of which take several parameters as input, that can be used to pry and tease out different aspects of correspondence between maps.

The range of possible map comparison methods is almost unlimited and therefore the task of map comparison remains subjective. The improvement over the common practive of face validation is that once a method has been selected the evaluation is objective and repeatable. The main contribution of this thesis therefore is that now it is possible to quantitatively express the correspondance between model and reality for models that emphasize the emergence of spatial structure. More specifically, the methods that are introduced fit well in a framework that assesses aspects of correspondance in structure and presence at a continuum of scales ranging from individual cells to the full landscape. 


\section{Chapter 8}

The quantitative nature of the analysis makes judgements verifiable, repeatable and unambiguous. Furthermore, it allows a systematic comparison of the performance of different models, applications of models to different regions, variations of models and different parameterizations of models. In other words, the modelling process is considerably better informed than before. The existence of performance criteria is a catalyst for further developments in the fields of land use modelling and geosimulation in general.

As a criterion of presence the Fuzzy Kappa statistic based on the fuzzy set map comparison is recommended. This metric measures the degree of cell-to-cell overlap, but with tolerance for near overlap and the confusion between similar categories. The use of fuzzy set techniques is flexible because different aspect of fuzziness can be incorporated. Temporal fuzziness may be a useful extension beyond locational and categorical fuzziness that are introduced and applied in this thesis. The particular strength of fuzzy set map comparison is that a great degree of fuzziness can be included in the analysis without loosing the information concering the cell itself. Other moving window approaches tend to become overly blurred.

The distance decay parameter of the fuzzy set map comparison as well as the categorical similarity matrix allow control over the comparison. In particular it is possible to focus on individual categories and separate omission from commission. A positive a side effect is that the similarity matrix can be used to compare maps of different legends. This is particularly interesting since parallel to this work other researchers have developed methods to create categorical similarity matrices to relate legends to each other (Ahlqvist 2005, Fritz \& See 2005).

Further insight into structural similarity is achieved via focal comparison of spatial structure metrics. Of the different metrics that are suggested, patch size has the most intuitive physical menaing. Two different methods of multi-scale analysis are introduced. Moving window analysis is most powerful for visualization and in the case studies discussed a strong tool of exploratory data analysis. The second method of wavelet transformation proves to be particularly useful for multi-scale analysis. Compared to other aggregation based multiscale approaches it stands out by separating spatial data layers into different scales and therefore evaluating different scales independently.

The proposed metrics offer input to the assessment of model performance at different spatial scales as wel as measurement scales. Consequently, the problem of interpretation and mutual comparability arises. Moreover it appears that even at the same spatial and measurement scale results are not necessarily comparable. There is considerable evidence for the intuition that predicting change is more difficult than predicting persistence. Therefore, a 'blind' comparison of seemingly equal scales may give a distorted view of a model's strengths and weaknesses. A basic solution to this problem is expressing model 
performance relative to the change that took place over the simulation period. This should be a minimal requirement for any validation of spatial dynamic models.

A more rigorous and generic approach of accounting for the context of the model is through the use of neutral models of landscape change. These models are subject to the same boundary conditions (including the initial situation) and constraints as the probed model. Comparing a model's performance relative to that of one or more neutral models provides insight into the extent to which model performance can be attributed to the model itself or to the context in which it is evaluated.

All methods discussed so far evaluate models by considering the final state of a model run. Arguably a dynamic model is best evaluated in terms of the changes that it creates rather than a static situation. That notion is explored in the last chapter of this thesis. The results are promising, but the method is neither exhausted nor fully developed. Since the method presented is a global map comparison it means that map dynamics over different regions can be compared, opening prospects of formal analysis and classification of land use dynamics. The development of metrics for the comparison of map dynamics is seen as a further development with great potential that surpasses the purpose of map comparison.

\subsection{New perspectives for model development}

One of the reasons to engage in this research was that any further developments in the field of land use modelling require a set of criteria against which proposed improvements and new ideas can be evaluated. Furthermore, there are several crucial decisions in the set-up of a Cellular Automata model for which no good objective criteria are available. Such decisions are the meta-parameters of the Cellular Automata model; the following questions need to be answer for any CA model application:

- What is the cell-size?

- Which land use classes are to be modelled?

- How long is the time step?

- What is the extent of the model area?

- For what period is the model applied?

In the past such questions, in particular the question of spatial resolution, have often been answered in light of the data that was available and the processing time of the computer (Benenson 2007). This practice is not typical of CA modelling only, but common in spatial analysis (Hengl 2006). These are crucial decisions however and should be made on solid grounds, with reference to the nature and purpose of the model. In recent years research is dedicated to the 


\section{Chapter 8}

sensitivity of Cellular Automata land use models that can inform such decisions (Dietzel \& Clarke 2004, 2006, Jantz \& Goetz 2005, Kocabas \& Dragicevic 2006, Ménard \& Marceau 2005, Pontius \& Malizia 2004).

A typical problem confronting these sensitivity analyses is that varying the meta-parameters does not only affect the outcomes of the model but also the appropriate reference levels. For instance, applying a model over a range of cell-sizes will produce different types and quantities of change over time. The performance of different runs should only be compared in light of this changed context, but in practice this is not the case.

This is a situation that is very similar to the one described in chapter 6 of this thesis. In that chapter the model is not applied under different settings, but it is evaluated according to various metrics at multiple scales. The various expressions of goodness-of-fit are not comparable amongst each other; therefore reference levels are established on the basis of a common reference model. The use of reference models would greatly advance the degree to which models at different resolutions and categorical aggregations can be compared and would allow an informed model specification on the basis of strength and weaknesses of the model under different settings of meta-parameters.

Cellular Automata modelling of land use processes is a field that remains under development. New developments take place in different areas, for instance integrating processes at multiple scales (Andersson et al. 2002, White 2006) incorporating economic principles in the transition rules (Webster \& $\mathrm{Wu}$ 1999a,b) and modelling land use-transport interaction (Geurs et al. 2006). These advances are made on theoretical grounds and therefore have their inherent merits. Nevertheless, ultimately the correspondence between theoretical model and reality needs to be expressed and the advances brought forward in this thesis provide ample tools.

When existing models are modified or extended, often a trade-off between the complexity of the model structure and the model performance has to be made. A guiding principle is parsimony (Chwif et al. 2000, Batty \& Torrens 2005); models should not be further complicated than is necessary to study the process of interest. This principle is also referred to as Occam's razor and by the popular Einstein quote "Make everything as simple as possible, but not simpler". The question to the modeller then is: where to stop? When do model extensions present more complications than improvements? The goodness-of-fit metrics presented in this thesis provide an important input to answer these questions and are thus not only relevant in the stage of model calibration and validation, but also for model development and model selection.

The calibration of Cellular Automata is a well known problem. The complex and self-organizing behaviour of Cellular Automata is attractive because it allows modelling of (urban) systems that display the same type of behaviour. At the same time, this complexity obscures the relationship between parameter 
values and model results, making it hard to find the optimal parameter values. The methods developed as part of this research complement the progress made in recent years in calibration of CA land use model. The goodness-of-fit metrics, or combinations thereof, can serve as objective functions in the optimization process. By incorporating spatial pattern and a tolerance for small spatial errors into the objective function, the calibration process will be focussed on those aspects of model performance that matter the most. Furthermore, calibration routines can be envisioned that exploit the rich information on various aspects of model performance to identify both the parameters to adjust and the required adjustment. Including multiple metrics of goodness-of-fit can be a strategy to prevent over-calibration as it provides extra constraints on the acceptable parameter space. In this context the relatively recent development of multi-objective optimization methods is of interest (Fonseca \& Fleming 1993). The premise of these methods is that multiple criteria are incorporated in the optimization process without a-priori determining the respective weights. Multi-objective optimization methods seek a so-called Pareto front, consisting of parameter values that cannot be improved upon according to one criterion without equivalent loss according to the other criteria.

\subsection{Validation of metrics, the importance of visualization}

The main contribution of this thesis is towards the developments of metrics for the measurement of goodness-of-fit between models. These metrics are useful in the validation and calibration of geosimulation models. How about the validity of the metrics themselves? To what extent can be ascertained that the metrics indeed capture relevant aspects of map correspondence?

The chapters have demonstrated the use and usefulness of the methods on both real and synthetic cases and datasets. The main method of assessing the comparison metrics is on the basis of different kinds of distribution of model agreement that follow from the methods. There are distributions over categories where for all legend classes separate goodness-of-fit values are calculated. Furthermore there are distributions of similarity over the outputs of different models, where the distribution of goodness-of-fit values is expected to correspond to prior expectations on the ranking of the models.

Most convincingly however, the metrics have been appraised on the basis of the spatial distribution of map agreement/ disagreement. When the comparison maps, expressing correspondence for all locations (cells) are convincingly aligned with our own visual impression the derived global metric also gains in standing. This mechanism strengthens our suspicion of the cell-by-cell based metrics of chapter 2 and the confidence in fuzzy set map comparison and the 


\section{Chapter 8}

multi-scale based comparison metrics of the later chapters. In one case of chapter 3 the agreement between human judgement and the automated method has been explicitly tested. In chapter 5 the importance of distributions became abundantly clear as the benefit of several metrics that only produce a single similarity value (and hence, no distribution) could not be demonstrated.

It is somehow ironic that with the purpose of making the validation of geosimulation models less dependant on subjective visual assessment and expert judgement, metrics are developed that are judged by essentially the same standard. Rather than eliminating subjectivity altogether, the border between objectivity and subjectivity has been redrawn. Most importantly, the comparison metrics allow maps to be compared automatically and consistently according to the same transparent standards. It must be acknowledged that the selection of these standards remains a subjective task.

It is not evident how map comparison metrics can be evaluated beyond this visual assessment. In the end, maps can be interpreted from many different perspectives and there is no reason to assume that one is intrinsically better than the other. A possible line of further research would be to investigate the effectiveness of different goodness-of-fit metrics in the calibration process. Such an experiment would not test the validity of a goodness-of-fit metric by itself but instead the interplay between the model, calibration method and goodness-of-fit metric. The quality of the metric would then be measured by its capacity to steer the calibration method towards the correct parameter values.

A useful validation exercise would be to revisit the experiment of Brown et al. (2005) who demonstrated that the calibration of a complex (agent based) spatial model on the basis of a single realization (the historical time path) can lead to wrong parameter estimations even if the model structure perfectly corresponds with reality. It would be interesting to investigate whether Brown et al. would have reached the same conclusions if a goodness-of-fit metric was used that is sensitive to spatial structure and has a tolerance for small spatial errors.

\subsection{Implementation in Map Comparison Kit}

The emphasis of this thesis has been on methodological development. All chapters introduce one or more quantitative methods to be used in the calibration and validation of geosimulation models. These methods cannot work without some type of software implementation. All methods presented in this thesis are made available in the Map Comparison Kit (Visser \& de Nijs, 2006) which is programmed in $\mathrm{C}++$ using the Geonamica ${ }^{\circledR}$ libraries and has a full graphical user interface. The Map Comparison Kit is developed by the Research Institute for Knowledge Systems for the Netherlands Environmental Assessment Agency and is available free of charge. 
The implementation is not just a convenience, but a necessity for the kind of analysis that is presented. It is emphasized at various points in this thesis that maps can be interpreted from many perspectives and hence, there is a practically unlimited number of ways of comparing maps. This is reflected firstly in the number of comparison methods that are available and secondly in the parameterization of these methods.

An analytical approach where the compared maps are fed into the software and a list of comparison metrics comes out would not be adequate. In order to understand the nature of the similarities and differences between maps an interactive and explorative approach is more appropriate. In such an approach the user compares maps and is presented not only with the summary statistics but also with visualizations of the differences. The user can identify salient aspects of the results and then select methods and parameters to focus on these aspects or, on the contrary, to filter these aspects away. Therefore the software possesses not onlythe functionality to run comparisons, but also to view the results and manipulate inputs.

Another factor necessitating a robust software implementation is the need to perform series of comparisons. For the calibration and sensitivity analysis a number of maps are compared according to the same standard. Multi-scale analysis compares maps according to the same method but with different settings. Performing these series of comparisons manually is time-consuming and prone to slips. The inclusion of tools in the Map Comparison Kit to automate such serial work saves time and prevents mistakes.

Finally, the comparison of maps is in many instances (perhaps too often) only a peripheral task inside larger projects. Without dedicated, user-friendly tools it is likely that this analysis does not get the attention and depth that it deserves, whereas even the availability of a single tool has the potential to change the state of the practice. The FRAGSTATS package (McGarical et al. 2002) and its impact on the field of Landscape Ecology is a leading example of such a tool.

\subsection{Current applications and further developments}

The first paper that resulted from the current research project already appeared several years ago which gives the opportunity to consider how this work has found its way into the scientific literature. By far, the most references are made to the fuzzy set map comparison of chapters 3 and 4 .

Many of the referring papers straightforwardly apply the methods as they are implemented in the Map Comparison Kit (e.g. Cloke \& Pappenberger 2008, Hemer 2006, Iverson et al. 2008a,b, White 2006, Klingseisen et al. 2008). Other papers introduce or use elements of the methods or introduce new methods that offer another perspective or correct flaws (e.g. Erni et al. 2007, Huang \& Lees 2007, Mas 2005, Pontius et al. 2004, Remmel \& Csillag 2006, Wealands et al. 


\section{Chapter 8}

2005). Yet others simply mark or acknowledge the methodological and theoretical contributions of the papers (e.g. Foody 2007, Kuhnert et al. 2005, Myint et al. 2007, Neumann et al. 2007).

The original purpose of the methods has been the evaluation of the performance of geosimulation models, in particular land use models. For a considerable part the papers that apply the methods proposed in this paper reflect the focus on land use models (Bone, Dragicevic \& Roberts 2006, Castella \& Verburg 2007, de Nijs, de Niet \& Crommentuijn 2004, Geertman, Hagoort \& Ottens 2007, Hagoort, Geertmans \& Ottens 2008; Hagoort 2006; Kasanko et al. 2008; Lee, Huang, \& Chan 2008; Ménard \& Marceau 2007, Straatman, White \& Engelen 2004, Verburg et al. 2002). Besides comparing models to re ality the method also found application in land use studies that examine land use dynamics by comparing maps over different moments in time (Meyfroidt \& Lambin 2008; Millington et al. 2008, Muilu \& Rusanen 2004).

The methods have found applications in other geosimulation domains too, in particular in hydrological modelling (Hemer 2006, Leyk et al. 2005, Leyk et al. 2004, Pappenberger et al. 2006, 2007, Wealands et al 2005, Zappa et al. 2008) and meteorological modelling (Ebert 2008, Cloke \& Pappenberger 2008) and integrated assessment / ecological modelling (Nasiri \& Huang 2008, van Delden et al. 2007. Loonen et al. 2006, Robinson 2007, Metzger et al. 2005a,b). Many ecological models concern the spatial distribution of species. For such applications the methods in this thesis are finding good use (Erni et al. 2007, Gergel et al. 2007,Gonzales \& Gergel 2007, Iverson et al. 2008a,b, Iverson \& Prasad 2007, Jewell et al. 2007, Leng et al. 2008, Prasad et al. 2006).

A third application is related to remote sensing, whereby ground observations are compared to remote sensing interpretations or different remote sensing interpretations are compared amongst each other. In particular the Fuzzy Kappa is recognized for its tolerance of small registration errors (Foody 2006, Foody 2007, Fritz \& See 2005, Fritz \& See 2008, See \& Fritz 2006, Gómez et al. 2007, Huang \& Lees 2007, Myint et al. 2007, Neumann et al. 2007). These remote sensing applications do not only concern land use / land cover, but also soil classification (Cockx et al. 2008), geomorphometric landscape analysis (Güntner et al. 2004, Klingseisen et al. 2008) and marine sediments monitoring (van der Wal \& Herman 2007)

The methods in this thesis have been a point of reference for several new developments of spatial and spatio-temporal analysis (Boots \& Csillag 2006, Brown et al. 2005, Dean 2005, Hargrove et all 2006, Kuhnert et al 2005, Mas 2005, Monmonier 2006, Pontius et al. 2004, Pontius et al. 2006, Pontius \& Malanson 2005,. Remmel \& Csillag 2006, Robertson et al. 2007, White 2006). Most surprising is the reference found in Dou et al. (2007) where a variation on the Fuzzy Kappa is used to compare brain scans. 
In general it seems that most of the scientific domains that were originally expected to benefit from map comparison methods that take a geographical perspective are indeed making use of the developed methods. Even domains that have their own long tradition of validation find use for these new methods, in particular remote sensing, meteorology and hydrology. This is most striking since the focus on categorical data is not ideal for those domains. Remote sensing classifications are often soft classified which means that rather than attaching a single category to a location, a likelihood for each category is produced. Meteorological and hydrological variables typically have a continuous scale e.g. pressure, flow velocity, discharge, temperature, etc. Categorizing such data before comparing maps introduces a loss of information to the analysis that is perhaps not necessary. In this light, a worthwhile avenue of further research and methodological development is to investigate how the concepts applied in this thesis can be applied on soft-classified and continuously scaled data. A cross-disciplinary literature scan (Hagen-Zanker 2006) indicates that such advances should take heed of developments in other domains, including the domain of (grey-scale) image processing.

One domain does not appear to make use of the methods is agent based modelling (ABM) or multi-agent systems (MAS), with Brown et al. (2005) as an exception. This rapidly developing form of geosimulation is confronted with the same kind of challenges concerning calibration and validation as the CA models that are the primary subject in this thesis. Moreover, many ABM models present their results in the form of categorical raster maps, therefore also on the technical level the methods are appropriate. Perhaps the lack of interest from the ABM field is related to its stage of development. ABM's are novel and still studied mainly at an abstract and theoretical level. Models are evaluated on the basis of their general plausibility and structural properties (Amblard et al. 2007, Parker \& Meretsky 2004) and are only occasionally applied for region specific studies.

A limitation of the cases in this thesis as well as the applications in the literature is that all applications of the methods developed are used for the post processing of model results, or otherwise generated maps. There is considerable scope however for integrating the comparison methods into the process of map creation. The potential for the calibration of geosimulation models was already stipulated in section 8.2, but another potential domain of integration is in remote sensing.

The mainstay of remote sensing classification is based on a pixel-by-pixel analysis. It is found, however, that classifications can improve if a larger extent of the context is taken into account. This holds in particular for land use classification, since the relation between land cover and land use is inherently context dependent (Wharton 1982, Alonso \& Soria 1991). The focal comparison methods can provide useful information on the spatial context of pixels, therefore both the fuzzy set map comparison of chapters 3 and 4 and the 


\section{Chapter 8}

landscape metric based methods of chapter 5 show good scope for integration in contextual classifications of land use. On a similar note, those methods as well as the transition based method of chapter 7 have potential for integration in change detection algorithms in remote sensing. 


\section{References}

Ahlqvist, O. (2005). Using uncertain conceptual spaces to translate between land cover categories. International Journal of Geographical Information Science, 19(7), 831-857.

Alonso, F. G., \& Soria, S. L. (1991). Using contextual information to improve land use classification of satellite images in central Spain. International Journal of Remote Sensing, 12(11), 2227-2235.

Amblard, F., Bommel, P., \& Rouchier, J. (2007). Assessment and validation of multi-agent models. In D. Phan \& F. Amblard (Eds.), Agent-based modelling and simulation in the social and human sciences (pp. 93-114). Oxford: The Bardwell Press.

Andersson, C., Rasmussen, S., \& White, R. (2002). Urban settlement transitions. Environment and Planning B: Planning and Design, 29, 841865.

Bak, P., Tang, C., \& Wiesenfeld, K. (1988). Self-organized criticality. Physical review A, 38(1), 364-374.

Bakkenes, M., Alkemade, J. R. M., Ihle, F., Leemans, R., \& Latour, J. B. (2002). Assessing effects of forecasted climate change on the diversity and distribution of European higher plants for 2050. Global Change Biology, 8(4), 390-407.

Bandemer, H., \& Gottwald, S. (1995). Fuzzy sets, fuzzy logic, fuzzy methods with applications. Chichester; New York: J. Wiley.

Barredo, J. I., \& Demicheli, L. (2003). Urban sustainability in developing countries' megacities: modelling and predicting future urban growth in Lagos. Cities, 20(5), 297-310.

Batty, M. (2005). Cities and complexity: understanding cities with Cellular Automata, agent-based models, and fractals: MIT Press.

Batty, M., \& Longley, P. (1994). Fractal cities: a geometry of form and function: Academic Press Professional, Inc. San Diego, CA, USA.

Batty, M., \& Torrens, P. M. (2005). Modelling and prediction in a complex world. Futures, 37(7), 745-766.

Benenson, I. (2007). Warning! The scale of land-use CA is changing! Computers Environment and Urban Systems, 31(2), 107-113. 
Benenson, I., \& Torrens, P. M. (2004). Geosimulation: object-based modeling of urban phenomena. Computers, Environment and Urban Systems, 28(1-2), $1-8$.

Binaghi, E., Brivio, P. A., Ghezzi, P., \& Rampini, A. (1999). A fuzzy set-based accuracy assessment of soft classification. Pattern Recognition Letters, 20(9), 935-948.

Bone, C., Dragicevic, S., \& Roberts, A. (2006). A fuzzy-constrained Cellular Automata model of forest insect infestations. Ecological Modelling, 192(12), 107-125.

Boots, B., \& Csillag, F. (2006). Categorical maps, comparisons, and confidence. Journal of Geographical Systems, 8(2), 109-118.

Boyce, W. E., \& DiPrima, R. C. (1997). Elementary differential equations and boundary value problems (6th ed.). New York: J. Wiley.

Briggs, W. M., \& Levine, R. A. (1997). Wavelets and field forecast verification. Monthly Weather Review, 125(6), 1329-1341.

Brown, D. G., Page, S., Riolo, R., Zellner, M., \& Rand, W. (2005). Path dependence and the validation of agent-based spatial models of land use. International Journal of Geographical Information Science, 19(2), 153-174.

Carletta, J. (1996). Assessing agreement on classification tasks: The kappa statistic. Computational Linguistics, 22(2), 249-254.

Castella, J. C., \& Verburg, P. H. (2007). Combination of process-oriented and pattern-oriented models of land-use change in a mountain area of Vietnam. Ecological Modelling, 202(3-4), 410-420.

Cheng, T., Molenaar, M., \& Lin, H. (2001). Formalizing fuzzy objects from uncertain classification results. International Journal of Geographical Information Science, 15(1), 27-42.

Chwif, L., Barretto, M. R. P., \& Paul, R. J. (2000). On simulation model complexity. Paper presented at the Simulation Conference.

Clarke, K. C., Hoppen, S., \& Gaydos, L. (1997). A self-modifying Cellular Automaton model of historical urbanization in the San Francisco Bay area. Environment and Planning B: Planning and Design, 24(2), 247-262.

Cleveringa, J., \& Oost, A. P. (1999). The fractal geometry of tidal-channel systems in the Dutch Wadden Sea. Geologie en Mijnbouw, 78(1), 21-30.

Cloke, H. L., \& Pappenberger, F. (2008). Evaluating forecasts of extreme events for hydrological applications: An approach for screening unfamiliar performance measures. Meteorological Applications, 15(1), 181-197.

CNES. (2006). Portail KALIDEOS, [Internet]. Available: http://kalideos.cnes.fr [2007, 18 May].

Cockx, L., van Meirvenne, M., \& de Vos, B. (2007). Using the EM38DD soil sensor to delineate clay lenses in a sandy forest soil. Soil Science Society of America Journal, 71(4), 1314-1322. 
Codd, E. F. (1968). Cellular Automata. New York,: Academic Press.

Cohen, J. A. (1960). Coefficient of agreement for nominal scales. Educational and Psychological Measurement, 20, 37-46.

Costanza, R. (1989). Model goodness of fit: a multiple resolution procedure. Ecological Modelling, 47(3-4), 199-215.

Csillag, F., \& Boots, B. (2005). Towards comparing maps as spatial processes. In P. F. Fisher (Ed.), Developments in spatial data handling : 11th International Symposium on Spatial Data Handling. Berlin ; New York: Springer.

de Nijs, T. C. M., de Niet, R., \& Crommentuijn, L. (2004). Constructing landuse maps of the Netherlands in 2030. Journal of Environmental Management, 72(1-2), 35-42.

Dean, D. J. (2005). Measuring arrangement similarity between thematic raster databases using a quadtree-based approach, Lecture Notes in Computer Science (including subseries Lecture Notes in Artificial Intelligence and Lecture Notes in Bioinformatics) (Vol. 3799 LNCS, pp. 120-136).

Dietzel, C., \& Clarke, K. C. (2004). Spatial differences in multi-resolution urban automata modeling. Transactions in GIS, 8(4), 479-492.

Dietzel, C., Herold, M., Hemphill, J. J., \& Clarke, K. C. (2005). Spatiotemporal dynamics in California's Central Valley: Empirical links to urban theory. International Journal of Geographical Information Science, 19(2), 175-195.

Dou, W., Ren, Y., Wu, Q., Ruan, S., Chen, Y., Bloyet, D., \& Constans, J. M. (2007). Fuzzy kappa for the agreement measure of fuzzy classifications. Neurocomputing, 70(4-6), 726-734.

Dungan, J. L. (2006). Focusing on feature-based differences in map comparison. Journal of Geographical Systems, 8(2), 131-143.

Ebert, E. E. (2007). Forecast verification - issues, methods and FAQ, [Internet]. Available:

http://www.bom.gov.au/bmrc/wefor/staff/eee/verif/verif_web_page.html [2007, 8 May].

Ebert, E. E. (2008). Fuzzy verification of high-resolution gridded forecasts: A review and proposed framework. Meteorological Applications, 15(1), 51-64.

Ebert, E. E., \& McBride, J. L. (2000). Verification of precipitation in weather systems: determination of systematic errors. Journal of Hydrology, 239(1-4), 179-202.

Ehlschlaeger, C. R. (2000). Representing uncertainty of area class maps with a correlated inter-map cell swapping heuristic. Computers, Environment and Urban Systems, 24(5), 451-469.

Engelen, G., White, R., \& de Nijs, T. (2003). Environment Explorer: spatial support system for the integrated assessment of socio-economic and 
environmental policies in the Netherlands. Integrated Assessment, 4(2), 97105.

Engelen, G., White, R., Uljee, I., \& Drazan, P. (1995). Using Cellular Automata for integrated modelling of socio-environmental systems. Environmental Monitoring and Assessment, 34(2), 203-214.

Erni, B., Altwegg, R., \& Underhill, L. G. (2007). An index to compare geographical distributions of species. Diversity and Distributions, 13(6), 829-835.

Fewster, R. M., \& Buckland, S. T. (2001). Similarity indices for spatial ecological data. Biometrics, 57, 495-501.

Fielding, A. H., \& Bell, J. F. (1997). A review of methods for the assessment of prediction errors in conservation presence/absence models. Environmental Conservation, 24(1), 38-49.

Finn, J. T. (1993). Use of the average mutual information index in evaluating classification error and consistency. International Journal of Geographical Information Science, 7(4), 349 - 366.

Fisher, P. (2000). Sorites paradox and vague geographies. Fuzzy Sets and Systems, 113(1), 7-18.

Fonseca, C. M., \& Fleming, P. J. (1993). Genetic algorithms for multiobjective optimization: Formulation, discussion and generalization.

Foody, G. M. (2002). Status of land cover classification accuracy assessment. Remote Sensing of Environment, 80(1), 185-201.

Foody, G. M. (2006). What is the difference between two maps? A remote senser's view. Journal of Geographical Systems, 8(2), 119-130.

Foody, G. M. (2007). Map comparison in GIS. Progress in Physical Geography, 31(4), 439-445.

Foody, G. M. (2008). Harshness in image classification accuracy assessment. International Journal of Remote Sensing, 29(11), 3137-3158.

Frankhauser, P. (1994). La fractalité des structures urbaines. Paris: Anthropos : Diffusion, Economica.

Fritz, S., \& See, L. (2005). Comparison of land cover maps using fuzzy agreement. International Journal of Geographical Information Science, 19(7), 787-807.

Fritz, S., \& See, L. (2008). Identifying and quantifying uncertainty and spatial disagreement in the comparison of Global Land Cover for different applications. Global Change Biology, 14(5), 1057-1075.

Gardner, M. (1970). Mathematical games: the fantastic combinations of John Conway's new solitaire game 'Life'. Scientific American, 223(4), 120-123.

Gardner, R. H., \& Urban, D. L. (2007). Neutral models for testing landscape hypotheses. Landscape Ecology, 22(1), 15-29. 
Geertman, S., Hagoort, M., \& Ottens, H. (2007). Spatial-temporal specific neighbourhood rules for Cellular Automata land-use modelling. International Journal of Geographical Information Science, 21(5), 547-568.

Gergel, S. E., Stange, Y., Coops, N. C., Johansen, K., \& Kirby, K. R. (2007). What is the value of a good map? An example using high spatial resolution imagery to aid riparian restoration. Ecosystems, 10(5), 688-702.

Geurs, K. T., van Wee, B., \& Rietveld, P. (2006). Accessibility appraisal of integrated land-use-transport strategies: methodology and case study for the Netherlands Randstad area. Environment and Planning B: Planning and Design, 33(5), 639-660.

Gómez, D., Biging, G., \& Montero, J. (2008). Accuracy statistics for judging soft classification. International Journal of Remote Sensing, 29(3), 693-709.

Gonzales, E. K., \& Gergel, S. E. (2007). Testing assumptions of cost surface analysis-a tool for invasive species management. Landscape Ecology, 22(8), 1155-1168.

Güntner, A., Seibert, J., \& Uhlenbrook, S. (2004). Modeling spatial patterns of saturated areas: An evaluation of different terrain indices. Water Resources Research, 40(5), W051141-W0511419.

Gupta, H. V., Sorooshian, S., \& Yapo, P. O. (1998). Toward improved calibration of hydrologic models: Multiple and noncommensurable measures of information. Water Resources Research, 34(4), 751-763.

Hagen-Zanker, A. (2006). Comparing continuous valued raster data: a cross disciplinairy literature scan. Maastricht: Research Institute for Knowledge Systems (RIKS).

Hagoort, M., Geertman, S., \& Ottens, H. (2008). Spatial externalities, neighbourhood rules and CA land-use modelling. Annals of Regional Science, 42(1), 39-56.

Hagoort, M. J. (2006). The neighbourhood rules: Land-use interactions, urban dynamics and Cellular Automata modelling, Nederlandse Geografische Studies (pp. 1-298).

Haines-Young, R., \& Weber, J.-L. (2006). Land accounts for Europe 19902000 : towards integrated land and ecosystem accounting (EEA Report 11/2006). Copenhagen: European Environment Agency.

Hargrove, W. W., Hoffman, F. M., \& Hessburg, P. F. (2006). Mapcurves: A quantitative method for comparing categorical maps. Journal of Geographical Systems, 8(2), 187-208.

Heidke, P. (1926). Berechnung des Erfolges und der Gute der Windstarkevorhersagen im Sturmwarnungsdienst. Geografiska Annaler, 8, 301-349. 
Hemer, M. A. (2006). The magnitude and frequency of combined flow bed shear stress as a measure of exposure on the Australian continental shelf. Continental Shelf Research, 26(11), 1258-1280.

Hengl, T. (2006). Finding the right pixel size. Computers and Geosciences, 32(9), 1283-1298.

Herold, M., Couclelis, H., \& Clarke, K. C. (2005). The role of spatial metrics in the analysis and modeling of urban land use change. Computers, Environment and Urban Systems, 29(4), 369-399.

Huang, Z., \& Lees, B. G. (2007). Assessing a single classification accuracy measure to deal with the imprecision of location and class: Fuzzy weighted Kappa versus Kappa. Journal of Spatial Science, 52(1), 1-12.

Iverson, L., Prasad, A., \& Matthews, S. (2008). Modeling potential climate change impacts on the trees of the northeastern United States. Mitigation and Adaptation Strategies for Global Change, 13(5-6), 487-516.

Iverson, L. R., \& Prasad, A. M. (2007). Using landscape analysis to assess and model tsunami damage in Aceh province, Sumatra. Landscape Ecology, 22(3), 323-331.

Iverson, L. R., Prasad, A. M., Matthews, S. N., \& Peters, M. (2008). Estimating potential habitat for 134 eastern US tree species under six climate scenarios. Forest Ecology and Management, 254(3), 390-406.

Jantz, C. A., \& Goetz, S. J. (2005). Analysis of scale dependencies in an urban land-use-change model. International Journal of Geographical Information Science, 19(2), 217-241.

Jewell, K. J., Arcese, P., \& Gergel, S. E. (2007). Robust predictions of species distribution: Spatial habitat models for a brood parasite. Biological Conservation, 140(3-4), 259-272.

Karssenberg, D., Burrough, P. A., Sluiter, R., \& de Jong, K. (2001). The PCRaster Software and Course Materials for Teaching Numerical Modelling in the Environmental Sciences. Transactions in GIS, 5(2), 99-110.

Kasanko, M., Sagris, V., Lavalle, C., Barredo, J. I., Petrov, L., Steinnocher, K., Loibl, W., \& Hoffmann, C. (2007, 11-13 April). GEOLAND spatial planning observatory: How remote sensing data can serve the needs of urban and regional planning. Paper presented at the 2007 Urban Remote Sensing Joint Event, URS.

Klingseisen, B., Metternicht, G., \& Paulus, G. (2008). Geomorphometric landscape analysis using a semi-automated GIS-approach. Environmental Modelling and Software, 23(1), 109-121.

Kocabas, V., \& Dragicevic, S. (2006). Assessing Cellular Automata model behaviour using a sensitivity analysis approach. Computers, Environment and Urban Systems, 30(6), 921-953. 
Kuhnert, M. (2002). Map comparison survey, [Internet]. Available: http://www.avm.edu/giee/AV/Maps/ [2002, June 26].

Kuhnert, M., Voinov, A., \& Seppelt, R. (2005). Comparing raster map comparison algorithms for spatial modeling and analysis. Photogrammetric Engineering and Remote Sensing, 71(8), 975-984.

Lagabrielle, E., Metzger, P., Martignac, C., Durieux, L., \& Grellet, G. (2005, 17 May 2007). Guide critique d'utilisation des informations produites dans le cadre du projet TEMOS à La Réunion, [Internet]. CIRAD. Available: http://www.cirad.fr/reunion/actualites/vient_de_paraitre/rapport_temos [2007, 18 May ].

Lajoie, G., \& Hagen-Zanker, A. (2007). La simulation de l'étalement urbain à La Réunion: Apport de l'automate cellulaire Metronamica ${ }^{\circledR}$ pour la prospective territoriale, Cybergeo (Vol. 405).

Langford, W. T., Gergel, S. E., Dietterich, T. G., \& Cohen, W. (2006). Map misclassification can cause large errors in landscape pattern indices: Examples from habitat fragmentation. Ecosystems, 9(3), 474-488.

Lardoux, J.-M. (2002). La population en 2030 : dans le cadre national. Revue économie de La Réunion, 112.

Lee, C. L., Huang, S. L., \& Chan, S. L. (2008). Biophysical and system approaches for simulating land-use change. Landscape and Urban Planning, 86(2), 187-203.

Leng, W., He, H. S., Bu, R., Dai, L., Hu, Y., \& Wang, X. (2008). Predicting the distributions of suitable habitat for three larch species under climate warming in northeastern China. Forest Ecology and Management, 254(3), 420-428.

Lewis, H. G., \& Brown, M. (2001). A generalized confusion matrix for assessing area estimates from remotely sensed data. International Journal of Remote Sensing, 22(16), 3223-3235.

Leyk, S., Boesch, R., \& Weibel, R. (2005). A conceptual framework for uncertainty investigation in map-based land cover change modelling. Transactions in GIS, 9(3), 291-322.

Leyk, S., \& Zimmermann, N. E. (2004). A predictive uncertainty model for field-based survey maps using Generalized Linear Models, Lecture Notes in Computer Science (Vol. 3234, pp. 191-205).

Loonen, W., Heuberger, P. S. C., Bakema, A. H., \& Schot, P. (2006). Application of a genetic algorithm to minimize agricultural nitrogen deposition in nature reserves. Agricultural Systems, 88(2-3), 360-375.

Maclure, M., \& Willet, W. C. (1987). Misinterpretation and misuse of the kappa statistic. American Journal of Epidemiology, 126(2), 161-169. 
Mas, J. F. (2005). Change estimates by map comparison: A method to reduce erroneous changes due to positional error. Transactions in GIS, 9(4), 619629.

McGarigal, K., Cushman, S. A., Neel, M. C., \& Ene, R. (2002). FRAGSTATS: spatial Pattern Analysis Program for Categorical Maps. Computer software program produced by the authors at the University of Massachusetts, Amherst. Available at the following web site: www.umass.edu/landeco/research/fragstats/fragstats.html.

Ménard, A., \& Marceau, D. J. (2005). Exploration of spatial scale sensitivity in geographic Cellular Automata. Environment and Planning B: Planning and Design, 32(5), 693-714.

Ménard, A., \& Marceau, D. J. (2007). Simulating the impact of forest management scenarios in an agricultural landscape of southern Quebec, Canada, using a geographic Cellular Automata. Landscape and Urban Planning, 79(3-4), 253-265.

Metternicht, G. (1999). Change detection assessment using fuzzy sets and remotely sensed data: an application of topographic map revision. ISPRS Journal of Photogrammetry and Remote Sensing, 54(4), 221-233.

Metzger, M. J., Bunce, R. G. H., Jongman, R. H. G., Mücher, C. A., \& Watkins, J. W. (2005). A climatic stratification of the environment of Europe. Global Ecology and Biogeography, 14(6), 549-563.

Metzger, M. J., Leemans, R., \& Schröter, D. (2005). A multidisciplinary multiscale framework for assessing vulnerabilities to global change. International Journal of Applied Earth Observation and Geoinformation, 7(4), 253-267.

Meyfroidt, P., \& Lambin, E. F. (2008). Forest transition in Vietnam and its environmental impacts. Global Change Biology, 14(6), 1319-1336.

Millington, J. D. A., Perry, G. L. W., \& Romero-Calcerrada, R. (2007). Regression techniques for examining land use/cover change: A case study of a mediterranean landscape. Ecosystems, 10(4), 562-578.

Monmonier, M. (2006). Cartography: Uncertainty, interventions, and dynamic display. Progress in Human Geography, 30(3), 373-381.

Monserud, R. A., \& Leemans, R. (1992). Comparing global vegetation maps with the Kappa statistic. Ecological Modelling, 62, 275-293.

Muilu, T., \& Rusanen, J. (2004). Rural definitions and short-term dynamics in rural areas of Finland in 1989-97. Environment and Planning A, 36(8), 14991516.

Mulligan, M. (1998). Modelling the geomorphological impact of climatic variability and extreme events in a semi-arid environment. Geomorphology, 24(1), 59-78.

Murray, A. B., \& Paola, C. (1994). A cellular model of braided rivers. Nature, 371(6492), 54-57. 
Myint, S. W., Wentz, E. A., \& Purkis, S. J. (2007). Employing spatial metrics in urban land-use/land-cover mapping: Comparing the Getis and Geary indices. Photogrammetric Engineering and Remote Sensing, 73(12), 1403-1415.

Næsset, E. (1996). Use of the weighted Kappa coefficient in classification error assessment of thematic maps. International Journal of Geographical Information Science, 10(5), 591-604.

Nasiri, F., \& Huang, G. (2008). A fuzzy decision aid model for environmental performance assessment in waste recycling. Environmental Modelling and Software, 23(6), 677-689.

Neumann, K., Herold, M., Hartley, A., \& Schmullius, C. (2007). Comparative assessment of CORINE2000 and GLC2000: Spatial analysis of land cover data for Europe. International Journal of Applied Earth Observation and Geoinformation, 9(4), 425-437.

Oreskes, N., Shraderfrechette, K., \& Belitz, K. (1994). Verification, validation, and confirmation of numerical models in the Earth sciences. Science, 263(5147), 641-646.

Pappenberger, F., Frodsham, K., Beven, K., Romanowicz, R., \& Matgen, P. (2006). Fuzzy set approach to calibrating distributed flood inundation models using remote sensing observations. Hydrology and Earth System Sciences Discussions, 3(4), 2243-2277.

Pappenberger, F., Frodsham, K., Beven, K., Romanowicz, R., \& Matgen, P. (2007). Fuzzy set approach to calibrating distributed flood inundation models using remote sensing observations. Hydrology and Earth System Sciences, 11(2), 739-752.

Parker, D. C., \& Meretsky, V. (2004). Measuring pattern outcomes in an agentbased model of edge-effect externalities using spatial metrics. Agriculture, Ecosystems and Environment, 101(2-3), 233-250.

Pijanowski, B. C., Brown, D. G., Shellito, B. A., \& Manik, G. A. (2002). Using neural networks and GIS to forecast land use changes: a Land Transformation Model. Computers, Environment and Urban Systems, 26(6), 553-575.

Pontius Jr, R. G., Huffaker, D., \& Denman, K. (2004). Useful techniques of validation for spatially explicit land-change models. Ecological Modelling, 179(4), 445-461.

Pontius Jr, R. G., \& Malanson, J. (2005). Comparison of the structure and accuracy of two land change models. International Journal of Geographical Information Science, 19(2), 243-265.

Pontius Jr, R. G., \& Malizia, N. R. (2004). Effect of category aggregation on map comparison. Lecture Notes in Computer Science, 3234, 251-268. 
Pontius Jr, R. G., Versluis, A. J., \& Malizia, N. R. (2006). Visualizing certainty of extrapolations from models of land change. Landscape Ecology, 21(7), 1151-1166.

Pontius Jr., R. G. (2000). Quantification error versus location error in comparison of categorical maps. Photogrammetric Engineering and Remote Sensing, 66(8), 1011-1016.

Pontius Jr., R. G. (2002). Statistical methods to partition effects of quantity and location during comparison of categorical maps at multiple resolutions. Photogrammetric Engineering and Remote Sensing, 68(10), 1041-1049.

Pontius Jr., R. G. (2002). Statistical methods to partition effects of quantity and location during comparison of categorical maps at multiple resolutions. Photogrammetric Engineering and Remote Sensing, 68(10), 1041-1049.

Pontius Jr., R. G., Boersma, W., Castella, J.-C., Clarke, K., de Nijs, T., Dietzel, C., Zengqiang, D., Fotsing, E., Goldstein, N., Kok, K., Koomen, E., Lippitt, C. D., McConnell, W., Pijanowski, B., Pithadia, S., Sood, A. M., Sweeney, S., Trung, T. N., Veldkamp, A. T., \& Verburg, P. H. (2008). Comparing the input, output, and validation maps for several models of land change. Annals of Regional Science, 42(1), 11-47

Pontius Jr., R. G., Huffaker, D., \& Denman, K. (2004). Useful techniques of validation for spatially explicit land-change models. Ecological Modelling, 179(4), 445-461.

Pontius Jr., R. G., \& Schneider, L. C. (2001). Land-cover change model validation by an ROC method for the Ipswich watershed, Massachusetts, USA. Agriculture Ecosystems \& Environment, 85(1-3), 239-248.

Pontius Jr., R. G., Walker, R., Yao-Kumah, R., Arima, E., Aldrich, S., Caldas, M., \& Vergara, D. (2007). Accuracy assessment for a simulation model of amazonian deforestation. Annals of the Association of American Geographers, 97(4), 677-695.

Popper, K. R. (1959). The logic of scientific discovery. New York,: Basic Books.

Power, C., Simms, A., \& White, R. (2001). Hierarchical fuzzy pattern matching for the regional comparison of land use maps. International Journal of Geographical Information Science, 15(1), 77-100.

Prasad, A. M., Iverson, L. R., \& Liaw, A. (2006). Newer classification and regression tree techniques: Bagging and random forests for ecological prediction. Ecosystems, 9(2), 181-199.

Railsback, S. F., Lytinen, S. L., \& Jackson, S. K. (2006). Agent-based Simulation Platforms: Review and Development Recommendations. SIMULATION, 82(9), 609.

Refsgaard, J. C., \& Henriksen, H. J. (2004). Modelling guidelines: terminology and guiding principles. Advances in Water Resources, 27(1), 71-82. 
Remmel, T. K., \& Csillag, F. (2006). Mutual information spectra for comparing categorical maps. International Journal of Remote Sensing, 27(7), 14251452.

Remmel, T. K., \& Perera, A. H. (2002). Accuracy of discontinuous binary surfaces: a case study using boreal forest fires. International Journal of Geographical Information Science, 16(3).

RIKS. (2003). Map Comparison Kit: User manual. Maastricht, the Netherlands: Research Institute for Knowledge Systems (RIKS).

Robertson, C., Nelson, T. A., Boots, B., \& Wulder, M. A. (2007). STAMP: Spatial-temporal analysis of moving polygons. Journal of Geographical Systems, 9(3), 207-227.

Robinson, V. B. (2007). Issues and challenges of incorporating fuzzy sets in ecological modeling, NATO Security through Science Series C: Environmental Security (pp. 33-51).

Rykiel, E. J. (1996). Testing ecological models: the meaning of validation. Ecological Modelling, 90(3), 229-244.

Samat, N. (2006). Characterizing the scale sensitivity of the Cellular Automata simulated urban growth: A case study of the Seberang Perai Region, Penang State, Malaysia. Computers, Environment and Urban Systems, 30(6), 905920.

Sargent, R. G. (1996). Verifying and validating simulation models. Proceedings of the 28th conference on Winter simulation, 55-64.

Schelling, T. C. (1971). Dynamic models of segregation. Journal of Mathematical Sociology, 1, 143-186.

Schneider, S. H. (1997). Integrated assessment modeling of global climate change: Transparent rational tool for policy making or opaque screen hiding value-laden assumptions? Environmental Modeling and Assessment, 2(4), 229-249.

See, L. M., \& Fritz, S. (2006). A method to compare and improve land cover Datasets: Application to the GLC-2000 and MODIS land cover products. IEEE Transactions on Geoscience and Remote Sensing, 44(7), 1740-1746.

Shalan, M. A., Arora, M. K., \& Elgy, J. (2003). CASCAM: crisp and soft classification accuracy measurement software. Paper presented at the 7 th International Conference on GeoComputation.

Shyi-Ming, C. (1995). Measures of similarity between vague sets. Fuzzy Sets and Systems, 74(2), 217-223.

Silva, E. A., \& Clarke, K. C. (2002). Calibration of the SLEUTH urban growth model for Lisbon and Porto, Portugal. Computers, Environment and Urban Systems, 26(6), 525-552. 
Silva, E. A., \& Clarke, K. C. (2002). Calibration of the SLEUTH urban growth model for Lisbon and Porto, Portugal. Computers, Environment and Urban Systems, 26(6), 525-552.

Stehman, S. V. (2002). Response to letter by G. Turk on chance correction and map evaluation. Remote Sensing of Environment, 82(1), 4.

Straatman, B., White, R., \& Engelen, G. (2004). Towards an automatic calibration procedure for constrained Cellular Automata. Computers, Environment and Urban Systems, 28(1-2), 149-170.

Takeyama, M., \& Couclelis, H. (1997). Map dynamics: integrating Cellular Automata and GIS through geo-algebra. International Journal of Geographical Information Science, 11(1), 73-91.

Takeyama, M., \& Couclelis, H. (1997). Map dynamics: integrating Cellular Automata and GIS through geo-algebra. International Journal of Geographical Information Science, 11(1), 73-91.

Tang, G. (2008). A new metric for evaluating the correspondence of spatial patterns in vegetation models. Global Ecology and Biogeography, 17(4), 465-478.

Tobler, W. R. (1970). A computer movie simulating urban growth in the Detroit region. Economic Geography, 46, 234-240.

Tobler, W. R. (1979). Cellular geography. Philosophy in Geography, 379-386.

Tolias, Y. A., Panas, S. M., \& Tsoukalas, L. H. (2001). Generalized fuzzy indices for similarity matching. Fuzzy Sets and Systems, 120(2), 255-270.

Turk, G. (2002). Chance correction and map evaluation. Remote Sensing of Environment, 82(1), 1-3.

Turner, M. G. (1987). Spatial simulation of landscape changes in Georgia: A comparison of 3 transition models. Landscape Ecology, 1(1), 29.

Turner, M. G., Costanza, R., \& Sklar, F. H. (1989). Methods to evaluate the performance of spatial simulation-models. Ecological Modelling, 48(1-2), 118.

Turner, M. G., Gardner, R. H., \& O'Neill, R. V. (2001). Landscape ecology in theory and practice : pattern and process. New York: Springer.

van Delden, H., \& Engelen, G. (2006). Combining participatory approaches and modelling: lessons from two practical cases of policy support. Paper presented at the the iEMSs Third Biennial Meeting: "Summit on Environmental Modelling and Software", Burlington, USA.

van Delden, H., Luja, P., \& Engelen, G. (2007). Integration of multi-scale dynamic spatial models of socio-economic and physical processes for river basin management. Environmental Modelling and Software, 22(2), 223-238.

van der Wal, D., \& Herman, P. M. J. (2007). Regression-based synergy of optical, shortwave infrared and microwave remote sensing for monitoring 
the grain-size of intertidal sediments. Remote Sensing of Environment, 111(1), 89-106.

Verburg, P. H., de Nijs, T. C. M., Ritsema van Eck, J., Visser, H., \& de Jong, K. (2004). A method to analyse neighbourhood characteristics of land use patterns. Computers, Environment and Urban Systems, 28(6), 667-690.

Verburg, P. H., Soepboer, W., Veldkamp, A., Limpiada, R., Espaldon, V., \& Mastura, S. S. A. (2002). Modeling the spatial dynamics of regional land use: The CLUE-S model. Environmental Management, 30(3), 391-405.

Visser, H., \& de Nijs, T. (2006). The map comparison kit. Environmental Modelling and Software, 21(3), 346-358.

Wang, X., De Baets, B., \& Kerre, E. (1995). A comparative study of similarity measures. Fuzzy Sets and Systems, 73(2), 259-268.

Wealands, S. R., Grayson, R. B., \& Walker, J. P. (2005). Quantitative comparison of spatial fields for hydrological model assessment - Some promising approaches. Advances in Water Resources, 28(1), 15-32.

Webster, C. J., \& Wu, F. (1999). Regulation, land-use mix, and urban performance. Part 1: theory. Environment and Planning A, 31(9), 15291547.

Webster, C. J., \& Wu, F. (1999). Regulation, land-use mix, and urban performance. Part 2: simulation. Environment and Planning A, 31(9), 15291545.

Wharton, S. W. (1982). A contextual classification method for recognizing land use patterns in high resolution remotely sensed data. Pattern Recognition, 15(4), 317-324.

White, R. (2006). Modeling multi-scale processes in a Cellular Automata framework. In J. Portugali (Ed.), Complex Artificial Environments (pp. 165177). Berlin, Heidelberg: Springer.

White, R. (2006). Pattern based map comparisons. Journal of Geographical Systems, 8(2), 145-164.

White, R., \& Engelen, G. (1993). Cellular Automata and fractal urban form: a cellular modelling approach to the evolution of urban land use patterns. Environment and Planning A, 25(8), 1175-1199.

White, R., \& Engelen, G. (2000). High-resolution integrated modelling of the spatial dynamics of urban and regional systems. Computers, Environment and Urban Systems, 24(5), 383-400.

White, R., \& Engelen, G. (2003, 5-9 September). A calibration procedure for constrained large neighbourhood Cellular Automata based land use models. Paper presented at the 13th European Colloquium on Theoretical and Quantitative Geography, Lucca, Italy. 
White, R., Engelen, G., \& Uljee, I. (1997). The use of constrained Cellular Automata for high-resolution modelling of urban land-use dynamics. Environment and Planning B: Planning and Design, 24(3), 323-343.

White, R., Engelen, G., Uljee, I., Lavalle, C., \& Ehrlich, D. (2000). Developing an urban land use simulator for European cities. In E. Fullerton (Ed.), Proceeedings of the 5-th EC-GIS Workshop held in Stresa, Italy 28-30 June 1999 (pp. 179-190). Ispra: European Commission, Joint Research Centre.

Wilson, W. G., De Roos, A. M., \& McCauley, E. (1993). Spatial instabilities within the diffusive Lotka-Volterra system: Individual-based simulation results. Theoretical Population Biology, 43(1), 91-127.

Winter, S. (2000). Location similarity of regions. ISPRS Journal of Photogrammetry and Remote Sensing, 55(3), 189-200.

With, K. A., \& King, A. W. (1997). The use and misuse of neutral landscape models in ecology. Oikos, 79(2), 219-229.

Wolfram, S. (1986). Theory and applications of Cellular Automata: including selected papers 1983-1986: World Scientific.

Zadeh, L. A. (1965). Fuzzy sets. Information and Control, 8(3), 338-353.

Zappa, M. (2008). Objective quantitative spatial verification of distributed snow cover simulations - An experiment for the whole of Switzerland. Hydrological Sciences Journal, 53(1), 179-191.

Zepeda-Arce, J., Foufoula-Georgiou, E., \& Droegemeier, K. K. (2000). Spacetime rainfall organization and its role in validating quantitative precipitation forecasts. Journal of Geophysical Research-Atmospheres, 105(D8), 1012910146.

Zuse, K. (1969). Rechnender Raum. Braunschweig, Germany: Vieweg.

Zwick, R., Carlstein, E., \& Budescu, D. V. (1987). Measures of similarity among fuzzy concepts: A comparative analysis. International Journal of Approximate Reasoning, 1(2), 221-242. 


\section{List of figures}

Figure 2.1 Cell-by-cell comparison of two maps ............................................ 42

Figure 2.2 Per category cell-by-cell comparison of map A and B .................. 43

Figure 2.3 Two sets of maps with identical Klocation values, despite clear differences in locational similarity .................................................................... 47

Figure 2.4 Scheme for using reference map comparison with Kappa statistic. 50 Figure 2.5 Atlas Flora Europaeae (left) and EuroMove (right) dataset and three

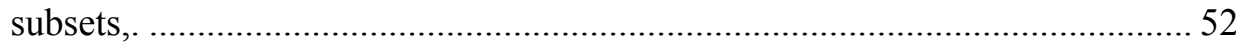

Figure 2.6 Environment Explorer dataset ........................................................5 54

Figure 2.7 Comparison scheme applied for Environment Explorer .................. 56

Figure 2.8 Comparison scheme applied for Environment Explorer with

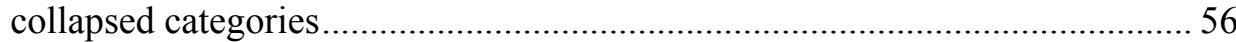

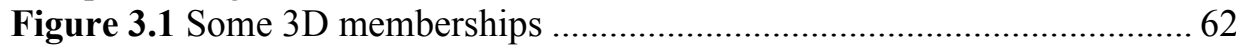

Figure 3.2 Neighbourhood, legend and distance relation ................................... 63

Figure 3.3 Two neighbourhoods and their central cells ................................... 64

Figure 3.4 Six situations in which the middle cells of the left and right map are compared, with consideration of fuzziness of location. Weights according exponential decay function with halving distance of $\sqrt{2}$................................6. 67

Figure 3.5 The two maps to compare. Different types of differences are marked on the second map.

Figure 3.6 Comparison results.................................................................. 75

Figure 3.7 Three levels of agreement by the proposed fuzzy comparison

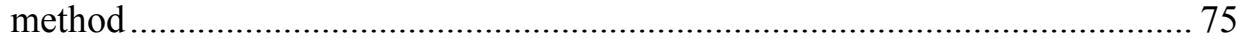

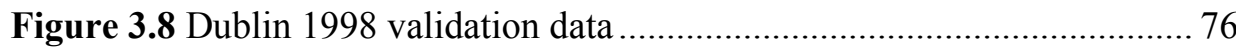

Figure 3.9 Three comparison results from validation process.......................... 78

Figure 3.10 Ten pairs of maps found in the web survey................................ 80

Figure 3.11 Correlation graphs, the automated comparison results are plotted

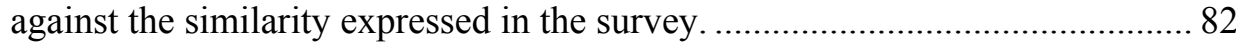

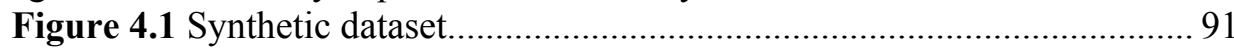

Figure 4.2 Fuzzy similarity, grey levels indicate local similarity, Fuzzy Kappa

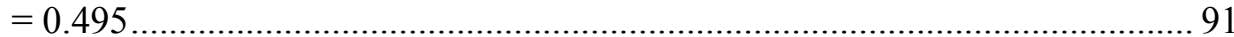

Figure 4.3 Disagreement per category and split into disagreement due to appearance (omission) and disappearance (commission)................................. 92

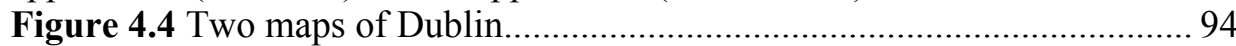

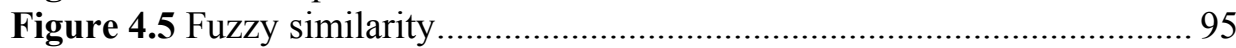

Figure 4.6 Fuzzy similarity of 'Road and rail networks and associated land'.. 96 Figure 4.7 Difference with respect to the category 'Residential discontinuous

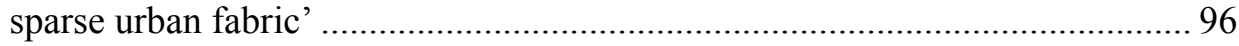


Figure 4.8 Difference with respect to the category 'Residential discontinuous

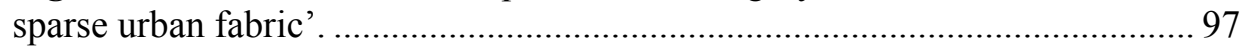

Figure 4.9 Difference with respect to category 'Industrial areas'................... 97 Figure 4.10 Two land use maps of the Netherlands. For different moments in time and with different legend classes........................................................... 98 Figure 4.11 Fuzzy Similarity of two maps with unequal legends .................. 101 Figure 5.1 Two pairs of maps that are both considered fully distinct from the perspective of overlap and identical from the perspective of landscape structure. Balanced analysis should find the first pair more similar. .............................. 104 Figure 5.2 Moving windows based similarity of the two pairs of maps in figure

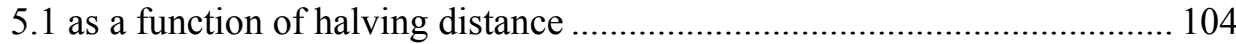
Figure 5.3 Data set D1. The maps contain 7 different classes........................ 114

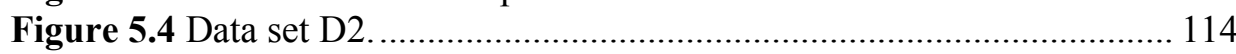

Figure 5.5 Reclassified maps of data set D1 ................................................. 114

Figure 5.6 Fuzzy similarity, for dataset D1.............................................. 115

Figure 5.7 Euclidean, for dataset D1 (weighted abundance).......................... 115

Figure 5.8 Per category similarity maps for omission and commission, $\alpha=2$ (same legend as figure 5.6)

Figure 5.9 Comparison on structure for data set D1. (positive values indicate

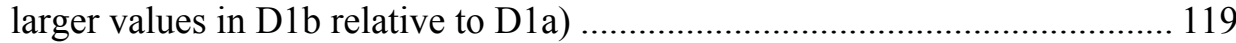

Figure 5.10 Fuzzy similarity, for dataset D2 ............................................ 120

Figure 5.11 Euclidean, for dataset D2 (weighted abundance) ........................ 120

Figure 5.12 Per category similarity maps for increase and decrease, $\alpha=2$ (same legend as figure 5.10)

Figure 5.13 Comparison on structure for data set D2 (positive values indicate larger values in D2b relative to D2a, thus an increase over time) ................... 122

Figure 5.14 Comparison on patch size for individual categories $(\alpha=2) \ldots \ldots .123$ Figure 6.1 Flowchart of model performance evaluation. The dashed lines indicate that Model constraints are not necessarily based on the initial and final map of reality, but in the current case they are............................................. 127

Figure 6.2 Haar wavelet decomposition of the error in urban presence......... 134

Figure 6.3 Geographical setting of La Réunion............................................ 136

Figure 6.4 Five land use maps, the original legend has been reduced to three main classes (after simulation) for legibility ................................................... 140

Figure 6.5 Multi-scale goodness-of-fit of presence of agriculture, with coarse scales on the left and fine scales on the right ................................................. 141

Figure 6.6 Patterns of agricultural change .................................................... 142

Figure 6.7 Multiscale goodness-of-fit for the class urban, with coarse scales on

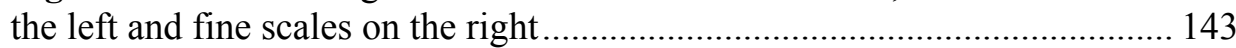

Figure 6.8 Multi-scale goodness-of-fit of agriculture according to Daubechies

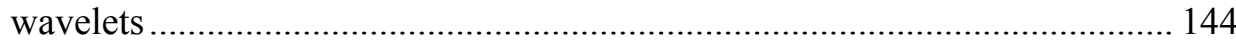

Figure 6.9 Multi-scale goodness-of-fit of urban presence under alternative padding options and Monte Carlo simulation 145 
Figure 6.10 Multi-scale, multi-criteria goodness-of-fit. Agriculture presence (AP), Urban presence (UP), Urban Urban patch size (US) and Urban fractal

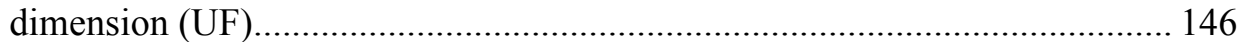

Figure 7.1 The geographical location $(\mathrm{x} 1, \mathrm{y} 1)$ changes location in state-space over time. The two axes represent distance to nature (vertical) and inhabitants within a $500 \mathrm{~m}$ radius (horizontal). Through time the location gains inhabitants and becomes further away from nature. 151

Figure 7.2 All locations combined provide a summary of the changes in the map. 151

Figure 7.3 A simple classification yields six categories. Distance to nature is expressed in two bins for biking and walking distance. Number of inhabitant ranges is classified as $\{$ low, medium, high 151

Figure 7.4 Reclassified land use maps of La Réunion. 154 



\section{List of tables}

Table 1.1 General framework within which the comparison methods of this

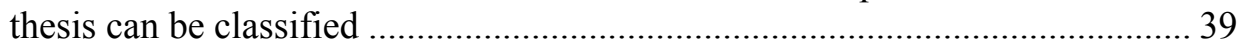

Table 2.1 Contingency table of map A and map B....................................... 43

Table 2.2 Proportions of agreement and disagreement, after Monserud \&

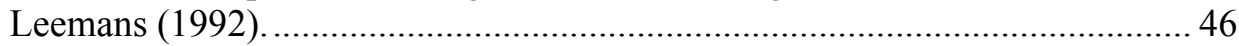

Table 2.3 Two contingency tables illustrating the stability problem................ 48

Table 2.4 Two contingency tables illustrating the symmetry problem.............. 48

Table 2.5 Reduced contingency table for a single category ……...................... 49

Table 2.6 Contingency tables corresponding to the maps in figure $2.5 \ldots \ldots \ldots \ldots . .52$

Table 2.7 Kappa statistics corresponding to the maps in figure 2.5 ................ 53

Table 2.8 Kappa results for the Environment Explorer, the simulated and observed maps for 1993 are compared .......................................................... 55

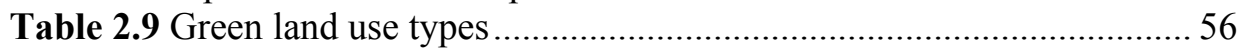

Table 3.1 Crisp Vector representation of four categories ..................................... 60

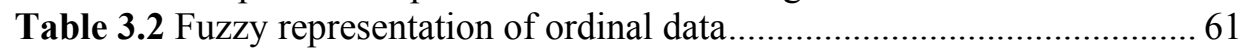

Table 3.3 Fuzzy representation of hierarchical data ........................................ 62

Table 3.4 Comparison results, $\mathrm{PoA}=$ proportion of agreement, $\mathrm{FK}=$ Fuzzy

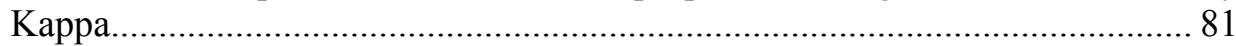

Table 4.1 An example similarity matrix where pine and broad leaved forest are

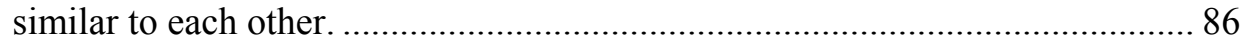

Table 4.2 An example similarity matrix where the residential categories have

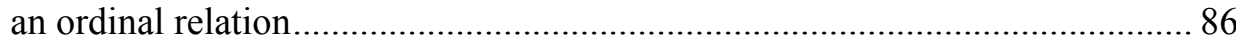

Table 4.3 An example similarity matrix where pine and broad leaved forest are

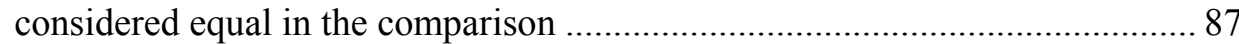

Table 4.4 An example similarity matrix where the category urban is considered

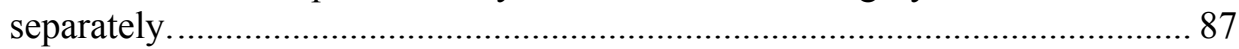

Table 4.5 An example similarity matrix where only commission of the category

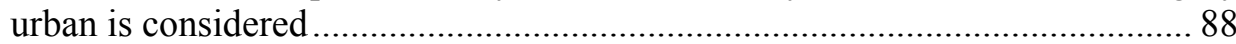

Table 4.6 An example similarity matrix where only omission of the category

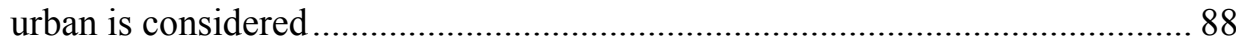

Table 4.7 An example similarity matrix where only the category urban is considered and omission weights stronger than commission........................... 88

Table 4.8 An example similarity matrix for the comparison of two maps with non-identical legends and a crisp translation key ............................................. 89

Table 4.9 An example similarity matrix for the comparison of two maps with non-identical legends and a fuzzy translation key. In this example the distinction between 'low density residential' and 'agricultural land' cannot 
always be made and the definition of 'pine forest' in map A partially overlaps 'agriculture' in map B

Table 4.10 Per category comparison results ................................................. 93

Table 4.11 Similarity matrices................................................................ 93

Table 4.12 Crisp categorical similarity matrix for two legends........................99

Table 4.13 Fuzzy categorical similarity matrix for two legends..................... 100

Table 5.1 Fuzzy confusion matrix $(* 1000$, Fuzzy weighted, $\alpha=2) \ldots \ldots \ldots \ldots \ldots . . .113$

Table 5.2 Prevalence, the strongest overlap for each category is highlighted 114

Table 5.3 Overall similarity and per category similarity for different metrics and settings. The category of lowest agreement is highlighted for every metric.

Table 5.4 Transition tables (fuzzy weighted abundance) .............................. 118

Table 5.5 Fuzzy kappa similarity profiles for upper and lower region $(\alpha=2) .120$

Table 6.1 Goodness-of-fit results for the criterion presence of agriculture. ... 139

Table 7.1 The normalized transition matrix tabulates all changes that occurred.

Table 7.2 Difference in transition pattern, based on land use fractions within a 10 cell radius. 155

Table 7.3 Normalized differences in transition pattern based on land use fractions within 4 different radii. 


\section{Biography}

Alex Hidde Hagen-Zanker was born on 9 January 1976 in Apeldoorn, the Netherlands. In Apeldoorn he followed primary and secondary education before moving to Delft and subsequently Enschede where he completed his studies of Civil Engineering and Management in 2001. Towards the end of his studies he moved to Maastricht to do his master thesis research at the Research Institute for Knowledge Systems (RIKS), a small company then owned by Maastricht University and led by Guy Engelen that specializes in planning support tools on the basis of geosimulation models.

RIKS subsequently hired Alex and since 2001 he has worked as a researcher on numerous projects and subjects related to geosimulation and spatial analysis. Besides map comparison, which is the topic of this thesis, he has worked on model integration and developed or improved models in various specific domains including transport, land use, regional science, geomorphology, ecology and hydrology.

As a RIKS researcher Alex has worked on and lead projects for various national and international clients, including the National Environmental Assessment Agency, the National Institute for Coastal Zone and Marine Management, European Environment Agency and the European Commission Joint Research Centre as well as several projects within research frameworks of the European Union.

Currently he continues working for RIKS as researcher and advisor. The majority of his time he spends on an exchange project at the Urban Planning Group of the Eindhoven Technical University. This exchange between RIKS and the university comes forth of a personal grant from the Netherlands Organisation for Scientific Research for research towards instruments for monitoring and analysis of urban change.

He has published 4 papers in journals listed in the Social Sciences Citation Index and over 10 in international conference proceedings or as book chapters. $\mathrm{He}$ is an active member of the Spatial Simulation for the Social Sciences (S4) European Research Group.

Alex lives with his wife Jessica and daughter Paola in Maastricht. 